\title{
Verpanding van aandelen en de beslotenheid van kapitaalvennootschappen : een beschouwing over het leerstuk der verpanding van aandelen in relatie tot enkele vennootschapsrechtelijke aspecten
}

Citation for published version (APA):

Hamers, J. J. A. (1996). Verpanding van aandelen en de beslotenheid van kapitaalvennootschappen : een beschouwing over het leerstuk der verpanding van aandelen in relatie tot enkele vennootschapsrechtelijke aspecten. [Doctoral Thesis, Maastricht University]. Kluwer. https://doi.org/10.26481/dis.19960621jh

Document status and date:

Published: 01/01/1996

DOI:

10.26481/dis.19960621jh

Document Version:

Publisher's PDF, also known as Version of record

Please check the document version of this publication:

- A submitted manuscript is the version of the article upon submission and before peer-review. There can be important differences between the submitted version and the official published version of record. People interested in the research are advised to contact the author for the final version of the publication, or visit the DOI to the publisher's website.

- The final author version and the galley proof are versions of the publication after peer review.

- The final published version features the final layout of the paper including the volume, issue and page numbers.

Link to publication

\footnotetext{
General rights rights.

- You may freely distribute the URL identifying the publication in the public portal. please follow below link for the End User Agreement:

www.umlib.nl/taverne-license

Take down policy

If you believe that this document breaches copyright please contact us at:

repository@maastrichtuniversity.nl

providing details and we will investigate your claim.
}

Copyright and moral rights for the publications made accessible in the public portal are retained by the authors and/or other copyright owners and it is a condition of accessing publications that users recognise and abide by the legal requirements associated with these

- Users may download and print one copy of any publication from the public portal for the purpose of private study or research.

- You may not further distribute the material or use it for any profit-making activity or commercial gain

If the publication is distributed under the terms of Article $25 \mathrm{fa}$ of the Dutch Copyright Act, indicated by the "Taverne" license above,

Download date: 26 Apr. 2023 
Verpanding van aandelen

en de

beslotenheid van

kapitaalvennootschappen 
. 


\title{
Verpanding van aandelen
}

\author{
en de
}

\author{
beslotenheid van
}

\section{kapitaalvennootschappen}

Een beschouwing over het leerstuk der verpanding van aandelen in relatie tot enkele vennootschapsrechtelijke aspecten

\section{PROEFSCHRIFT}

ter verkrijging van de graad van doctor aan de Rijksuniversiteit Limburg te Maastricht, op gezag van de Rector Magnificus, Prof. mr M.J. Cohen, volgens het besluit van het College van Dekanen, in het openbaar te verdedigen op vrijdag 21 juni 1996 om 14.00 uur

door

Joseph Johannes Antonius Hamers 
$\begin{array}{ll}\text { Promotor: } & \text { Prof. mr C.A. Schwarz }\end{array}$

Beoordelingscommissie: Prof. mr H.J. de Kluiver (voorzitter)

Prof. mr P.J. Dortmond (Katholieke Universiteit Nijmegen)

Prof. dr G.W. Mincke 
"Und bald hatte sich das Leben gänzlich normalisiert. Die Leute arbeiteten fleißig und schliefen gut und gingen ihren Geschäften nach und hielten sich rechtschaffen."

(Uit 'Das Parfum', Patrick Süskind) 


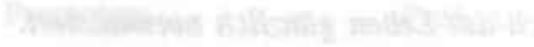

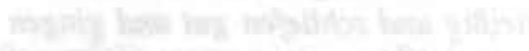

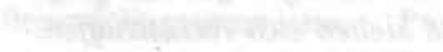

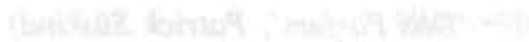




\section{Voorwoord}

Na enkele jaren ligt het er dan: "Verpanding van Aandelen".

Van aio, via universitair docent in tijdelijke dienst naar universitair docent in vaste dient. Een lange weg. Periodes van onderwijs en daartussen, onderzoek en schrijven. Enkelen hebben het schrijven van het proefschrift betiteld als een 'eenzame aangelegenheid'. Dit is niet mijn ervaring. Velen hebben deel gehad aan de totstandkoming van dit boek. Familie, collega's, vrienden en studenten. Allen leefden en dachten mee. Hiervoor ben ik erg dankbaar.

In de eerste plaats ben ik bijzonder veel dank verschuldigd aan mijn promotor, prof. mr C.A. Schwarz. Als aio ben ik onder zijn veren gekropen en begonnen aan het schrijven van dit boek. Als universitair docent heb ik, eveneens onder zijn leiding, het manuscript afgerond. Daar tussen uren, zelfs dagen van intensieve samenwerking. Hij toonde zich een geduldig man met een scherpe en snelle geest, die zijn enthousiasme voor en kennis van het vak op gedreven wijze op mij overbracht. Veel mocht ik van hem leren.

Daarnaast dank aan prof. mr H.J. de Kluiver, voorzitter van de beoordelingscommissie. Dank ook aan prof. mr P.J. Dortmond en prof. dr G.W. Mincke leden van de beoordelingscommissie.

Bij mr S.F.G. Rammeloo kon ik terecht om mijn juridische gedachten(sprongen) te testen. Telkenmale vond ik een gewillig oor. Bedankt Stephan.

Mevrouw L.W. Rayar, B.tr MITI, verzorgde op voortreffelijke wijze de Engelstalige samenvatting, waarvoor ik haar zeer erkentelijk ben.

In de periode dat mijn boek de eindstreep naderde kon ik bouwen op de secretariële ondersteuning van de vakgroep privaatrecht. In het bijzonder gaat mijn dank uit naar mevrouw Ine Corstjens.

Tenslotte, maar zeker niet in de laatste plaats dank aan mijn Moeder, Marieke en Ton. Zij zijn degenen die echt hebben afgezien, zeker in de afrondingsfase van het manuscript. Desondanks waren zij bakens waarop ik blindelings kon varen.

Maastricht, maart 1996 




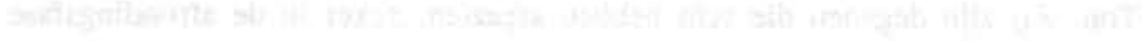

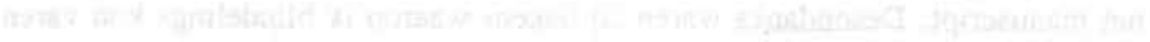




\section{Afkortingen}

A.Ae
AK
art(t).
Bb
BV
BW
curs.
diss.
eds.
Fusie Gedragsregels

Fw

herz.

HR

INBW

JBN

$\mathrm{K}$

lk

MBB

Mon.Nieuw BW

MvA

MvT

NBW

NJ

NJB

NJV

nt.

NTBR

NV

NV $x x(x x x x)$

OK

$p(p)$.

red.
Ars Aequi

Administratiekantoor

artikel(en)

Bedrijfsjuridische berichten

besloten vennootschap

Burgerlijk Wetboek

cursief

dissertatie

editors

SER-Besluit Fusiegedragsregels 1975. Besluit van 21 november 1975, zoals laatstelijk gewijzigd bij besluit van de raad van 15 januari 1991, in werking getreden 15 januari 1991

Faillissementswet

herzien

Hoge Raad

Invoeringswet Nieuw Burgerlijk Wetboek

Juridische berichten voor het Notariaat

Wetboek van Koophandel

linker kolom

Maandblad Belastingbeschouwingen

Monografieën Nieuw BW

Memorie van Antwoord

Memorie van Toelichting

Nieuw Burgerlijk Wetboek

Nederlandse Jurisprudentie

Nederlands Juristenblad

Nederlandse Juristen Vereniging

met noot

Nederlands Tijdschrift voor Burgerlijk Recht

naamloze vennootschap

De Naamlooze Vennootschap Jaargang (jaar)

Ondernemingskamer van het Gerechtshof te Amsterdam

pagina('s)

redactie 
Richtlijnen 1986

$\operatorname{Rv}$

RvdW

Stb.

Stcrt.

TK

TVVS

$\mathrm{V} \& O$

Wet Vpb

WGE

WPNR

WTE
Departementale Richtlijnen 1986 voor het beoordelen van oprichtingen en van statutenwijzigingen van naamloze en besloten vennootschappen (met beperkte aansprakelijkheid)

Wetboek van Burgerlijke Rechtsvordering

Rechtspraak van de Week

Staatsblad

Staatscourant

Tweede Kamer der Staten-Generaal

Tijdschrift voor vennootschappen, verenigingen en stichtingen

Vennootschap en Onderneming

Wet op de vennootschapsbelasting 1969

Wet Giraal Effectenverkeer

Weekblad voor Privaatrecht, Notariaat en Registratie

Wet Toezicht Effectenverkeer 


\section{Inhoudsopgave}

Voorwoord

Afkortingen IX

Inhoudsopgave

$\mathrm{XI}$

DEEL I Verpanding van aandelen; Algemene aspecten

I.1 Inleiding 3

I.2 De Wet vruchtgebruik en pandrecht op aandelen 7

I.3 Verpanding van aandelen in naamloze en besloten $\begin{array}{ll}\text { vennootschappen; de wettelijke regeling } & 13\end{array}$

$\begin{array}{lll}\text { I.3.1 Inleiding } & 13\end{array}$

$\begin{array}{lll}\text { I.3.2 Wettelijk kader } & 13\end{array}$

$\begin{array}{lll}\text { I.3.3 Mogelijkheid van verpanding van aandelen } & 15\end{array}$

$\begin{array}{lll}\text { 1.3.3.1 Algemeen } & 15\end{array}$

$\begin{array}{ll}\text { I.3.3.2 Naamloze vennootschap } & 16\end{array}$

$\begin{array}{ll}\text { I.3.3.3 De besloten vennootschap } & 18\end{array}$

I.4 Het in pand nemen van eigen aandelen 21

$\begin{array}{lll}\text { I.5 Vestiging van pandrecht op aandelen } & 27\end{array}$

$\begin{array}{lll}\text { I.5.1 De nieuwe regeling } & 32\end{array}$

$\begin{array}{lll}\text { I.5.2 De nieuwe regeling nader bezien } & 37\end{array}$

1.5.2.1 Stil pandrecht op aandelen op naam in een BV of in een gewone - niet beursgenoteerde - NV?

1.5.2.2 Openbaar en stil pandrecht op aandelen op naam; goede trouw en bescherming 41

I.5.3 Verpanding van aandelen in een depot 46

I.6 Overgang van stemrecht verbonden aan verpande aandelen 47

I.7 Aandeelhoudersrechten; pandhoudersrechten 53

I.8 Goederenrechtelijke bevoegdheden en verplichtingen

$\begin{array}{lll}\text { I.9 Relatie pandhouder - vennootschap } & 65\end{array}$

$\begin{array}{lll}\text { I.10 Pandrecht van certificaathouders } & 69\end{array}$

$\begin{array}{lll}\text { I.10.1 Inleiding } & 69\end{array}$

$\begin{array}{lll}\text { I.10.2 Certificering van aandelen } & 69\end{array}$

I.10.3 Bewilligd versus niet-bewilligd certificaat; medewerking 73 
I.10.4 Wettelijk pandrecht; vestiging van een 'gewoon' pandrecht; gevolgen

I.10.5 Lidmaatschapsrechten; organisatorische betrokkenheid 84

$\begin{array}{ll}\text { I.10.6 Executie van het wettelijk pandrecht } & 92\end{array}$

I.11 Beslag op en parate executie van aandelen door de pandhouder 95

$\begin{array}{lll}\text { I.11.1 Inleiding } & 95\end{array}$

I.11.2 Executie en beslag; algemene opmerkingen 97

I.11.3 Executie van aandelen aan toonder en aandelen op naam; algemeen

$\begin{array}{lll}\text { 1.11.4 Executoriaal beslag op aandelen } & 102\end{array}$

$\begin{array}{ll}\text { I.11.5 Conservatoir beslag op aandelen } & 106\end{array}$

$\begin{array}{lll}\text { I.11.6 Pandexecutie } & 107\end{array}$

$\begin{array}{lll}\text { I.12 Einde van het pandrecht } & 113\end{array}$

DEEL II Verpanding van aandelen in relatie tot enkele vennootschapsrechtelijke aspecten

Pandrecht op aandelen en de beslotenheid van de vennootschap

II. 1 Inleiding

II.2 Naamloze vennootschap en besloten naamloze vennootschap

II.3 Aard van de beslotenheid van de - naamloze - vennootschap

II.4 De Eerste EG-richtlijn en de besloten vennootschap met beperkte aansprakelijkheid

$\begin{array}{lll}\text { II.5 Verschijningsvormen van kapitaalvennootschappen } & 139\end{array}$

II.6 Een pas op de plaats; herbezinning 143

II.7 Verpanding van aandelen; de beslotenheid in gevaar? 151

II.7.1 Inleiding

II.7.2 Artikel $89 \mathrm{BW}$; open naamloze vennootschap; geen schending van de beslotenheid

II.7.3 Artikel 198; de intern-besloten vennootschap; gevaar voor doorbraak

II.7.4 Besloten en gemengde naamloze vennootschap; het gevoelige raakvlak

II.7.5 Gevolgen van stil pandrecht voor de beslotenheid van het samenwerkingsverband

II.7.6 Wettelijke bescherming van de beslotenheid in geval van verpanding van aandelen 
II.8 De positie van de pandhouder in geval van een juridische fusie

II.8.1 Inleiding

II.8.2 Bescherming van de pandhouder in geval van een juridische fusie

II.8.3 Zaaksvervanging ondanks verbod van verpanding? 184

II.8.4 Pandhouder met stemrecht. Ook op de nieuwe aandelen? 185

Pandrecht op aandelen en de uitkoop- en geschillenregeling 189

$\begin{array}{lll}\text { II.9 Inleiding } & 189\end{array}$

$\begin{array}{ll}\text { II.10 De uitkoopregeling } & 191\end{array}$

II.10.1 Uitkoopregeling en pandrecht 196

$\begin{array}{lll}\text { II.10.2 Relatie uitkoper - aandeelhouder/pandgever } & 196\end{array}$

$\begin{array}{lll}\text { II.10.3 Relatie uitkoper - pandhouder } & 200\end{array}$

II.10.4 Relatie pandgever - pandhouder 201

II.11 De geschillenregeling in relatie tot in pand gegeven aandelen 205

$\begin{array}{lll}\text { II.11.1 Inleiding } 205 & \end{array}$

II.11.2 Uitstoting, uittreding en vordering tot overgang van het stemrecht 206

II.11.3 Positie van de pandhouder in geval van uitstoting, uittreding en gedwongen overgang van het stemrecht 208

Samenvatting

Summary

Lijst van geraadpleegde en verkort aangehaalde literatuur

Trefwoordenregister

Curriculum Vitae 



\section{Deel I}

Verpanding van aandelen Algemene aspecten 



\section{I.1 Inleiding}

In het Nederlandse rechtspersonenrecht komt men op een aantal plaatsen het begrip pandrecht op aandelen tegen. ${ }^{1}$

Tot de inwerkingtreding van de Wet vruchtgebruik en pandrecht op aandelen ${ }^{2}$ waren in onze wetgeving geen bijzondere bepalingen opgenomen betreffende het vestigen van pandrecht en vruchtgebruik op aandelen. De gevolgen daarvan voor de, bij de pandovereenkomst en de overeenkomst tot vestiging van vruchtgebruik, betrokken partijen werden evenmin geregeld. Men was dus aangewezen op de bepalingen inzake pandrecht en vruchtgebruik in het algemeen (artt. 3:803 (oud) e.v. en 3:1196 (oud) e.v. BW; artt. 3:201 e.v. en 3:227 e.v. BW). Deze regels werden nu eens letterlijk of vrijwel letterlijk, dan weer slechts naar analogie toegepast. Dat dit niet altijd wenselijk was, moge duidelijk zijn. ${ }^{3}$ Een uitzondering dient hier vermeld te worden. Het Wetboek van Koophandel regelde het zogenaamde "bestuurspand". 4

De bij de Wet vruchtgebruik en pandrecht op aandelen ingevoerde wettelijke bepalingen geven een uitvoerige regeling van het fenomeen pandrecht op aandelen. ${ }^{5}$ Ondanks de specifieke bepalingen betreffende pandrecht op aandelen in Boek 2 van het Burgerlijk Wetboek zal echter toch nog herhaaldelijk een terugkoppeling dienen plaats te vinden naar de algemene bepalingen van het pandrecht. Dit zal enerzijds gebeuren bij de beschrijving van de bijzondere bepalingen ten

1 Zie onder andere de artt. 85 e.v., 194 e.v., 391 e.v., 338, 342 BW.

2 Wet van 17 mei 1976, Stb. 28, in werking getreden op 26 juli 1976 gelijktijdig met de Invoeringswet Boek 2 BW; zie ook J.M.M. Maeijer, Wetsgeschiedenis deel IV, p. IXk-a.

3 Zie voor beschrijvingen van het recht voor invoering van de wet vruchtgebruik en pandrecht op aandelen 0.a. O.K. Brahn, Vruchtgebniik en pandrecht op aandelen volgens Boek $2 \mathrm{NBW}$, TVVS 1975 p. 195 e.v.; H.P.J.M. Coebergh, Vruchtgebruik en pandrecht op - en levering van aandelen, NV 52 (1974), p. 75 e.v.

4 Artikelen 48d en 58c WvK: "Pandrecht ten behoeve van de Naamloze Vennootschap op aandeelen van een bestuurder, ter verzekering van de nakoming van zijne verplichtingen als zoodanig kan worden gevestigd, wat aandeelbewijzen aan toonder en volgestorte aandeelen op naam betreft, door hunne inbewaargeving onder een derde ten name der vennootschap met medewerking van commissarissen, of, bij gebreke van dezen, van een of meer aandeelhouders, daartoe bij de akte van oprichting of door de algemeene vergadering aangewezen, en, ten aanzien van niet volgestorte aandeelen op naam, door eene daartoe strekkende aanteekening in het register van aandeelhouders en gelijke bewaargeving onder een derde van de bij deze aandeelen behoorende dividendbewijzen, zoo deze aan toonder luiden." Deze artikelen zijn vervallen bij Wet van 8 april 1976, Stb. 229, in werking getreden op 26 juni 1976.

5 De regeling van vruchtgebruik op aandelen zal in de onderhavige studie slechts dan aan de orde komen indien dit voor de behandeling van de regeling van bet pandrecht op aandelen noodzakelijk is. 
aanzien van verpanding van aandelen, anderzijds zal ook teruggekoppeld worden bij de behandeling van enkele problemen van vennootschapsrechtelijke en goederenrechtelijke aard, die inherent zijn aan het fenomeen pandrecht op aandelen. In het bijzonder zal dan gekeken moeten worden naar de algemene regeling van pandrecht op vorderingen en pandrecht op rechten aan toonder en op naam (artt. 3:236, 237, $246 \mathrm{BW}$ ).

Het doel van dit werk is allereerst te komen tot een analyse van het instituut pandrecht op aandelen en de daarop betrekking hebbende regels. Hierbij zal zowel de vennootschapsrechtelijke- als de goederenrechtelijke kant worden belicht. Deze analyse zal plaatsvinden in het eerste - algemene - deel van dit boek. Ook wordt aandacht besteed aan het wettelijk pandrecht ten behoeve van de gezamenlijke houders van bewilligde certificaten van aandelen.

In het tweede deel van dit onderzoek zal de nadruk worden gelegd op enkele vennootschapsrechtelijke aspecten van de verpanding van aandelen. Uitgebreid zal aandacht worden besteed aan de gevolgen die een verpanding van aandelen kan hebben voor de beslotenheid van besloten en naamloze samenwerkingsverbanden. Voorts zullen aan de orde komen: de relatie tussen uitkoop van aandelen en een pandrecht dat rust op de uit te kopen aandelen, de relatie geschillenregeling en pandrecht en de status van verpande aandelen in geval van een juridische fusie (en natuurlijk de gevolgen voor de bij deze fusie betrokken partijen).

In deze studie zal niet - danwel zijdelings - worden ingegaan op de wijze en de rol van verpanding van aandelen in de rechtsstelsels van andere West-Europese landen. Evenmin zal aandacht worden besteed aan vragen van internationaal privaatrecht.

In het kader van deze studie past ook de vraag naar de maatschappelijke relevantie van het fenomeen pandrecht op aandelen. Bij de beantwoording van deze vraag dient vooropgesteld te worden dat er weinig gegevens omtrent verpanding van aandelen, ter meerdere zekerheid voor de voldoening van een (geld)schuld met voorrang boven andere crediteuren, openbaar gemaakt worden. In deze studie zal ik een antwoord trachten te geven op de vraag naar de maatschappelijke relevantie van het pandrecht. ${ }^{6}$

6 Zie voor enige algemene opmerkingen en enkele, zij het gedateerde, cijfers betreffende de maatschappelijke relevantie van het pandrecht (als zekerheidsrecht) $F$. Molenaar, Pandrecht, Mon. Nieuw BW, B12a, $2^{e}$ druk, 1991, Kluwer, Deventer, p. 1-2 en F. Molenaar, Algemene Bepalingen zekerheidsrechten op goederen, Mon. Nieuw BW 11 B-Serie, 1992, Kluwer, Deventer, p. 10-12. In zijn bespreking van Handelsrecht. Algemene inleiding en ondernemingsrecht van Van Oven en Löwensteyn merkt W.J. Slagter op dat de verhandeling op het gebied van het vruchtgebruik en pandrecht op aandelen te uitgebreid is; vide TVVS 1990, p. 50. Naar mijn mening kan de theorievorming op dit gebied niet uitgebreid genoeg zijn. Immers, de praktijk geeft te kennen moeite te hebben met het fenomeen van de verpanding van aandelen. Zie o.a. de Paretti/Melia-zaak, NRC 19-11-1991, De Telegraaf 19-11-1991. In de navolgende paragraaf, aangaande de Wet vnuchtgebruik en pandrecht op aandelen, zal eveneens aandacht worden 
Ter afsluiting van deze inleiding de volgende opmerking. Voor wat betreft de vermelde wetsartikelen geldt dat, indien bij het artikel niet is aangegeven in welk Boek van het Burgerlijk Wetboek het is opgenomen, dit Boek 2 is.

Bij de regels van het algemene vermogensrecht is steeds angegeven in welk Boek zij zijn opgenomen: bepalingen uit de Boeken 3, 5 en 6 worden steeds voorafgegaan door het cijfer van het betreffende Boek gevolgd door een dubbele punt. aandelen al eerder de belangstelling van wetenschappers wekte blijkt uit het proefschrift van $J$. $G$. Meilink, Over verpanding, in het bijzonder van aandeelen op naam in een Naamloze Vennootschap, diss. leiden, Eduard Udo, 1898. 



\section{I.2 De Wet vruchtgebruik en pandrecht op aandelen}

Bij Koninklijke Boodschap van 9 april 1974 werd bij de Tweede Kamer der Staten-Generaal een wetsontwerp ingediend getiteld: "Aanvulling van Boek 2 Burgerlijk Wetboek (vruchtgebruik en pandrecht op aandelen). ${ }^{77}$

Het wetsvoorstel werd ingediend naar aanleiding van een in 1971, door de toenmalige Minister van justitie C.H.F. Polak, gedane toezegging. Deze toezegging, dat te zijner tijd zou worden terug gekomen op de vestiging van zakelijke rechten op registeraandelen, werd door de Minister gedaan ten tijde van de behandeling van het wetsvoorstel Regeling van de besloten vennootschap met beperkte aansprakelijkheid. ${ }^{8}$

Het probleem van deze zakelijke rechten is vooral acuut geworden door de invoering van de besloten vennootschap met beperkte aansprakelijkheid, zulks in verband met de verplichte blokkering van de vrije overdraagbaarheid van de aandelen in deze vennootschap. ${ }^{9}$ Bij de blokkering doet zich namelijk de vraag voor, in hoeverre het besloten karakter van de vennootschap wordt aangetast indien de aandeelhoudersrechten vrijelijk op de zakelijk gerechtigden mogen, danwel kunnen overgaan. ${ }^{10}$ De beslotenheid van het samenwerkingsverband kan tevens in gevaar worden gebracht door de gevolgen van executie van de goederenrechtelijke rechten die op de aandelen zijn gevestigd. Zonder op deze plaats te diep op deze materie in te gaan geef ik een voorbeeld. Indien een pandhouder overgaat tot executie van een groot pakket aandelen in een besloten vennootschap en voor de overdracht van die aandelen een aanbiedingsblokkade in de statuten is opgenomen, kan de overname van dat pakket voor de overige aandeelhouder(s) financieel - bezwaarlijk en eventueel onmogelijk zijn. Dit gegeven kan de beslotenheid in gevaar brengen. Eenzelfde consequentie is te verbinden aan een

7 TK 12897 , nr. 1.

8 TK 10689, p. 2995

9 TK 12 897, nr. 3, p. 4; zie omtrent het leerstuk van de blokkering van aandelen, C.A. Schwarz, Blokkering van aandelen, diss.

10 TK 12897 , nr. 3, p. 4. Zie ook J.M.M. Maeijer, Wetsgeschiedenis, p. LXk-a. Naast deze problemen die voortvloeien uit de relatie blokkering van aandelen en zakelijke rechten, gevestigd op geblokkeerde aandelen, geeft Maeijer in zijp algemene inleiding aan dat, bij gebrek aan een specifieke regeling van verpanding van aandelen, enkele vragen kunnen rijzen waarover verschillend kan worden geoordeeld. Zo zijn, volgens Maeijer, de meningen verdeeld ten aanzien van de vraag aan wie bij vruchtgebruik (m.i. ook bij pandrecht; $\mathrm{JH}$ ) de aan het aan het aandeel verbonden zeggensmacht toekomt, indien daaromtrent statutair dan wel in de overeenkomst van vruchtgebruik of de pandakte niets geregeld is. Voorts vraagt Maeijer zich af wat rechtens is als de pandhouder zijn verhaalsrecht op het aandeel gaat vitoefenen. Op deze en andere vragen zal in deze paragraaf nader worden ingegaan. 
weigering tot het verlenen van goedkeuring aan de overdracht. In art. 195 lid 3 BW wordt immers bepaald dat, indien gelijktijdig met de weigering van de goedkeuring tot overdracht geen andere gegadigde door het orgaan dat met de beslissing omtrent goedkeuring is belast wordt aangewezen, de goedkeuring wordt geacht te zijn verleend. Het gevolg hiervan is dat de vervreemder zijn aandelen kan overdragen aan een partij, die niet de voorkeur geniet van het goedkeurend orgaan van de vennootschap.

Het onderwerp is in studie geweest bij de Commissie Vennootschapsrecht. Dit heeft geleid tot een voorstel voor een wettelijke regeling betreffende de vestiging van beperkte zakelijke rechten zowel op registeraandelen in een besloten vennootschap als op aandelen - meer in het bijzonder op naam - in een naamloze vennootschap. ${ }^{11}$

Bij brief van 14 augustus 1973 werd het ontwerp van de Commissie Vennootschapsrecht, tezamen met een Memorie van Toelichting, aan de Tweede Kamer aangeboden. Het ontwerp werd, op enkele ondergeschikte wijzigingen na, in het regeringsontwerp gevolgd. ${ }^{12}$

Daar de invoering van Boek 2 van het Burgerlijk Wetboek voor de deur stond, werd de ontworpen regeling opgenomen in Boek 2 BW en niet in het Wetboek van Koophandel, zulks overigens in afwijking van het advies van de Commissie Vennootschapsrecht. ${ }^{13}$

Bij de voorbereiding van het onderhavige wetsvoorstel zijn de makers uitgegaan van een aantal basisvragen. ${ }^{14}$ In de eerste plaats vroeg men zich af, of het vestigen van vruchtgebruik op aandelen in een besloten - danwel (besloten) naamloze - vennootschap verboden zou moeten kunnen worden. Ten aanzien van deze vraag werd opgemerkt dat de vestiging van vruchtgebruik veelal geschiedt ter uitvoering van een legaat ter voorziening in het onderhoud van de langst levende echtgenoot. Daarom dient de mogelijkheid van vruchtgebruik op aandelen niet statutair te kunnen worden uitgesloten.

Een tweede vraag die aan de orde kwam, was of er mogelijkheden zouden moeten zijn tot een verbod van de vestiging van pandrecht op aandelen. Uit de Memorie van Toelichting blijkt dat de ontwerpers van de onderhavige regeling de mening waren toegedaan dat de maatschappelijke behoefte aan verpanding van

11 TK 12897 , nr. 3, p. 4.

12 TK 12897 , nr. 3, p. 4.

13 TK 12897 , nr. 3, p. 4.

14 TK 12897 , nr. 3, p. 4. 
aandelen minder groot was dan die aan vruchtgebruik van aandelen. ${ }^{15}$ Daarom dienen de vennootschapsrechtelijke belangen doorslaggevend te zijn. Hierbij wordt evenwel opgemerkt dat aandelen aan toonder, gelijk roerende lichamelijke zaken, nimmer aan verpanding kunnen worden onttrokken. Bij aandelen op naam zou het mogelijk moeten zijn verpanding te verbieden. Men kan immers ten aanzien van een vordering op naam ook overeenkomen dat deze niet kan worden verpand.

Voorts vroeg men zich af of, voor zover de vestiging van vruchtgebruik mogelijk is, die regeling met zich brengt dat de vruchtgebruiker stemrecht heeft en indien deze vraag niet zonder meer bevestigend kan worden beantwoord, van welke voorwaarden toekenning van het stemrecht aan de vruchtgebruiker afhankelijk zou moeten zijn. ${ }^{16}$ Daar vruchtgebruik van aandelen, zoals reeds eerder werd opgemerk ${ }^{17}$, veelal voorkomt bij een erfrechtelijke overgang, waarbij zij vaak dient ter voldoening aan een morele verzorgingsverplichting en reeds daarom niet mag worden uitgesloten, zal het voomamelijk gaan om de economische waarde van de aandelen en niet in de eerste plaats om de zeggenschap die aan de aandelen verbonden is. Gaat het stemrecht over op de vruchtgebruiker dan kan de beslotenheid van de vennootschap, op wier aandelen een vruchtgebruik gevestigd wordt, verloren gaan. Slechts indien het vennootschappelijk belang niet door de stemovergang wordt geschaad, kan aan partijen de vrijheid worden gelaten te bepalen dat met de vestiging van het vruchtgebruik ook het stemrecht overgaat. Dit zal dus met name voor kunnen komen bij de openbare naamloze vennootschap (dus bij het vestigen van een recht van vruchtgebruik op aandelen aan toonder). Echter, ook bij de naamloze vennootschap met een besloten kern kan dit probleem spelen. Indien de overdracht van aandelen op naam beperkt is, dan wil dit niet automatisch zeggen dat de overdracht van zeggensmacht aan de vruchtgebruiker eveneens, door de wet, beperkt is. Evenwel kan de overgang van zeggensmacht bij deze vennootschappen statutair beperkt worden.

Voor wat de besloten vennootschap betreft kan worden opgemerkt dat het stemrecht, ingevolge art. 197 lid $3 \mathrm{BW}$, op de vruchtgebruiker kan overgaan, indien deze een persoon is die tot de kring van personen behoort aan wie de aandelen vrijelijk, dat wil zeggen zonder inachtneming van de blokkeringsregeling, kunnen

15 In de huidige tijd kan men zich afvragen of deze opvatting wel juist is. Het in onderpand geven van aandelen ter verkrijging van een banklening is aan de orde van de dag. Zie HR 6 april 1990 , NJ 1991, 559 (Canadian Land) en, naar aanleiding van dit arrest, $L$. Timmerman, Stemrecht op verpande aandelen, TVVS 1990, p. 202.

16 Zie art. 3:219 BW; de hoofdregel ten aanzien van stemrecht op aandelen in geval van vruchtgebruik is dat, buiten de gevallen geregeld in de artikelen 2:88 en $197 \mathrm{BW}$, de uitoefening van het stemrecht verbonden aan een goed dat aan vruchtgebruik is onderworpen, aan de hoofdgerechtigde toekomt, tenzij bij de vestiging van het vruchtgebruik anders is bepaald.

17 Zie TK 12897 , nr. 3, p. 4. 
worden overgedragen. ${ }^{18}$ Deze regeling sluit aan bij de ratio van de blokkeringsregeling, zijnde het waarborgen van het besloten karakter van de vennootschap door te bepalen dat aandelen in een besloten vennootschap - met uitzondering van de overdracht binnen de vrije kring - niet vrij overdraagbaar zijn. De idee hierbij was aandeelhouders zeggenschap te verschaffen over de samenstelling van het door hun aangegane samenwerkingsverband. ${ }^{19}$ Indien het aandeel vrij kan worden overgedragen bestaat er mijns inziens geen bezwaar tegen een overgang van het stemrecht verbonden aan de in vruchtgebruik gegeven aandelen van aandeelhouder naar vruchtgebruiker.

Volgens de Memorie van Toelichting zal in andere dan de bovengenoemde gevallen het stemrecht slechts op de vruchtgebruiker kunnen overgaan indien de vennootschap dit goedkeurt. ${ }^{20}$ Het zou echter mogelijk moeten zijn, zowel bij de naamloze als bij de besloten vennootschap, de vestiging van vruchtgebruik met overgang van stemrecht statutair uit te sluiten. "Het is de bedoeling dat deze uitsluiting beperkt kan zijn tot een bepaalde soort aandelen. Het is echter niet de bedoeling, dat het verbod slechts van toepassing zal zijn op bepaalde categorieën van besluiten. ${ }^{\text {"21 }}$

De vierde vraag, ten grondslag liggend aan onderhavig wetsontwerp, luidde of, en onder welke omstandigheden, de pandhouder bij verpanding van aandelen het stemrecht zou moeten hebben.

Hiervoor werd reeds opgemerkt dat, ten aanzien van verpanding van aandelen, het vennootschappelijk belang, in de ogen van de wetgever, dient te prevaleren boven het persoonlijke belang van de pandgever en dus boven het, te allen tijde, scheppen van de mogelijkheid van verpanding van aandelen op naam. "Dit vennootschappelijk belang, kan met meer reden de doorslag geven bij de toekenning van het stemrecht en wel niet alleen bij aandelen op naam maar ook bij toonder aandelen omdat het de pandhouder toch in de eerste plaats om het economische belang gaat. Ook hier kan dus in principe het stemrecht bij de aandeelhouder blijven. "22

Naar aanleiding van de overwegingen in de MvT ten aanzien van de scheiding tussen de economische waarde van het aandeel en het stemrecht van de in

18 Deze vrije kring, gedefinieerd in art. 195 lid $1 \mathrm{BW}$, waarbinnen aandelen zonder inachtneming van blokkeringsregelingen kunnen worden overgedragen, kan statutair beperkt of uitgesloten worden.

19 Zie C.A. Schwarz, Blokkering van aandelen, diss. p. 37.

20 Met het oog op de ratio van de blokkeringsregeling dient hier een zekere nuancering in het standpunt van de Minister te worden aangebracht. Naar mijn mening dient deze passage uit de MvT gelezen te worden als stond er "het stemrecht slechts op de vruchtgebruiker kunnen overgaan indien de algemene vergadering van aandeelhouders dit goedkeurt". In een werkelijk besloten samenwerkingsverband past het immers niet de bedoelde goedkeuring over te laten aan een ander vennootschapsorgaan dan de algemene vergadering van aandeelhouders.

21 TK 12897 , nr. 3, p. 5.

22 TK 12897 , nr. 3, p. 5. 
vruchtgebruik gegeven danwel verpande aandelen, merkten enkele leden van de PvdA-fractie op dat de economische waarde van het aandeel samenhangt met het stemrecht op die aandelen. Door middel van het stemrecht kan men immers de economische waarde van het aandeel beïnvloeden..$^{23}$

De Minister van Justitie erkent de juistheid van de stelling van de PvdA-fractie. Evenwel gaat hij er van uit dat de wetgever bepaalde keuzes moet maken, waarvan overigens, onder de door de wet aangegeven omstandigheden, kan worden afgeweken. De Minister merkt op:

\begin{abstract}
"Het belang van de aandeelhouders bij het behoud van hun zeggenschapsrechten weegt in het algemeen zwaarder. Evenals het belang dat aandeelhouders er bij kunnen hebben dat de beslotenheid van de groep niet tegen hun wil door het stemrecht van derden wordt doorbroken. Bij deze laatste belangen is de zeggenschap in de vennootschap in volle omvang betrokken. Bij de belangen van de vruchtgebruiker en pandhouder is dat slechts het geval, voorzover door het uitoefenen van zeggenschap het vermogen in stand wordt gehouden en dividend wordt uitgekeerd. Deze belangen worden ook op andere wijze redelijk beschermd. Zo zullen vruchtgebruikers en pandhouders (dikwijls) de rechten van certificaathouders hebben. ${ }^{.24}$
\end{abstract}

Het eerste argument dat door de Minister wordt genoemd - het belang van de aandeelhouders bij het behoud van hun zeggenschapsrechten - acht ik niet bijzonder sterk. Immers, de aandeelhouder zelf beslist over de voorwaarden waaronder hij de pandovereenkomst aangaat. Niet het belang van de aandeelhouder, maar het vennootschappelijk belang zou van doorslaggevende aard moeten zijn. Het tweede argument dat door de Minister wordt aangevoerd - het belang van de aandeelhouders dat de beslotenheid niet tegen hun wil in wordt doorbroken - acht ik eveneens niet bijzonder sterk. De aandeelhouders zijn immers op het moment waarop zij tot het samenwerkingsverband toetraden akkoord gegaan met de statuten, de structuur van de organisatie, van de vennootschap. $\mathrm{Zij}$ zijn dus tevens akkoord gegaan met de statutaire bepalingen betreffende de wijze van verpanding van aandelen en de mogelijkheid al dan niet het stemrecht over te dragen aan de pandhouder. De bescherming die de Minister voorstaat dient mijns inziens aan de discretie van de aandeelhouders te worden overgelaten.

23 TK 12897 , nr. 5, p. 1.

24 TK 12897 , nr. 6, p. 2. De minister doelde hier op de volgende rechten (zie TK 12897 , nr. 3, p. 5 en 6): het recht op inzage van de jaarstukken (42b WvK oud), bet recht tot bijeenroeping van de algemene vergadering met een tiende van het geplaatste kapitaal (43c WvK oud), het recht tot oproeping tot algemene vergadering ( $43 \mathrm{f} \mathrm{WvK}$ oud), het recht tot bijwoning van de algemene vergadering ( $44 \mathrm{a}$ WvK oud), het recht tot het uitlokken van een enquete door een tiende van of $f 500.000,=$ in het geplaatste kapitaal (53 WvK oud). In de MvA (TK $12897, \mathrm{nr}$. 6. p. 1 en 2) merkt de minister bovendien op dat de vruchtgebruiker en de pandhouder een besluit, bijvoorbeeld tot bepaling of bestemming van de winst, dat in strijd met de wet, de statuten of de goede trouw is genomen, kunnen doen vernietigen. Zie ook $\$$ I.9. 
Na de beschrijving van de vragen die ten grondslag lagen aan de voorbereiding van het wetsontwerp vruchtgebruik en pandrecht op aandelen ${ }^{25}$, zal vervolgens worden ingegaan op de implementatie van de onderhavige wet in Boek 2 van het Burgerlijk Wetboek; een analyse van de artt. 89 en $198 \mathrm{BW}$.

25 Op deze plaats zal niet verder worden ingegaan op het Vooropig Verslag, de NvW, de Nota van Wijzigingen, Het Eind Verslag, de Nota ten aanzien van het Eind Verslag en de Tweede Nota van Wijzigingen betreffende wetsontwerp 12897. 


\section{I.3 Verpanding van aandelen in naamloze en besloten vennootschappen; de wettelijke regeling}

\section{I.3.1 Inleiding}

In de vorige paragraaf is de totstandkoming en de inhoud van de Wet vruchtgebruik en pandrecht op aandelen aan de orde geweest. Beschreven werden de vragen die ten grondslag lagen aan de voorbereiding van het wetsontwerp en de wet. In de onderhavige paragraaf zal nader worden ingegaan op de gevolgen van de inwerkingtreding van deze wet. Kortom, onderwerp van deze paragraaf zijn de artt. 89 en 198 Boek 2 BW. ${ }^{26}$

In deze paragraaf zal de volgende wijze van behandeling worden gevolgd. Allereerst $\mathrm{zal}$ het wettelijk kader inzake verpanding van aandelen worden gegeven. Vervolgens zal aandacht worden besteed aan de mogelijkheid tot verpanden van aandelen.

\section{I.3.2 Wettelijk kader ${ }^{27}$}

Art. $89 \mathrm{BW}$

Lid 1. De bevoegdheid tot verpanding van aandelen aan toonder kan bij de statuten niet worden beperkt of uitgesloten. Op aandelen op naam kan pandrecht worden gevestigd, voor zover de statuten niet anders bepalen.

lid 2. De aandeelhouder heeft het stemrecht op de verpande aandelen.

lid 3. In afwijking van bet voorgaande lid komt het stemrecht toe aan de pandhouder, indien zulks bij de vestiging van het pandrecht is bepaald en de pandhouder een persoon is, aan wie de aandelen vrijelijk kunnen worden overgedragen. Indien de pandhouder een persoon is aan wie de aandelen niet vrijelijk kunnen worden overgedragen, komt hem het stemrecht uitsluitend toe, indien dit bij de vestiging van het pandrecht is bepaald, en de bepaling is goedgekeurd door het vennootschapsorgaan dat bij de statuten is aangewezen om goedkeuring te verlenen tot een voorgenomen overdracht van aandelen, dan wel - bij het ontbreken van zodanige aanwijzing - door de algemene vergadering van aandeelhouders. Treedt een ander in de rechten van de pandhouder, dan komt hem het stemrecht slechts toe, indien het in de vorige zin bedoelde orgaan dan wel, bij gebreke daarvan, de algemene ver-

26 De artt. 89 en $198 \mathrm{BW}$ zijn niet de enige twee artikelen die naar aanleiding van de Wet vruchtgebruik en pandrecht op aandelen in Boek 2 zijn opgenomen. Gewijzigd, dan wel zijn toegevoegd zijn onder meer de artt. 85, 86, 89, 91, 183, 194, 196, 197, 199, 200. Zie voorts art. $474 \mathrm{c} \mathrm{Rv}$.

27 De verschillen in de redactie van de art. 89 en $198 \mathrm{BW}$, die later besproken zullen worden, zijn gecursiveerd weergegeven. 
gadering van aandeelhouders de overgang van het stemrecht goedkeurt. Van het bepaalde in de voorgaande drie zinnen kan in de statuten worden afgeweken.

lid 4. De aandeelhouder die geen stemrecht heeft, en de pandhouder die stemrecht heef, hebben de rechten die door de wet zijn toegekend aan de houders van met medewerking ener vennootschap uitgegeven certificaten van aandelen. De pandhouder die geen stemrecht heeft, heeft deze rechten, tenzij deze hem bij de vestiging of overgang van het pandrecht of bij de statuten van de vennootschap worden onthouden.

lid 5. De bepalingen van de statuten ten aanzien van de vervreemding en de overdracht van aandelen zijn van toepassing op de vervreemding en overdracht van de aandelen door de pandhouder of de verblijving van de aandelen aan de pandhouder, met dien verstande dat de pandhouder alle ten aanzien van de vervreemding en overdracht aan de aandeelhouder toekomende rechten uitoefent en diens verplichtingen ter zake nakomt.

lid 6. Is het pandrecht overeenkomstig artikel $86 \mathrm{c} \mathrm{lid} 4 \mathrm{gevestigd,} \mathrm{dan} \mathrm{komen} \mathrm{de} \mathrm{rechten}$ volgens dit artikel de pandhouder eerst toe nadat het pandrecht door de vennootschap is erkend of aan haar is betekend. ${ }^{28}$

Ar. 198 BW:

lid 1. Op aandelen kan pandrecht worden gevestigd, indien de starusen niet anders bepalen. lid 2. De aandeelhouder heeft het stemrecht op de verpande aandelen.

lid 3. In afwijking van het voorgaande lid komt het stemrecht toe aan de pandhouder, indien zulks bij de vestiging van het pandrecht is bepaald en de pandhouder een persoon is, aan wie de aandelen overeenkomstig artikel 195 lid 1 van dit Boek vrijelijk kunnen worden overgedragen. Indien de pandhouder niet zulk een persoon is, komt hem het stemrecht uitsluitend toe indien dit bij de vestiging van het pandrecht is bepaald en de vestiging van het pandrecht is goedgekeurd door het vennootschapsorgaan dat bij de statuten is aangewezen om goedkeuring te verlenen tot een voorgenomen overdracht van aandelen, dan wel bij ontbreken van zodanige aanwijzing - door de algemene vergadering van aandeelhouders. Treedt een ander in de rechten van de pandhouder, dan komt hem het stemrecht slechts toe, indien het in de vorige zin bedoelde orgaan dan wel, bij gebreke daarvan, de algemene vergadering de overgang van het stemrecht goedkeurt. De bevoegdheid tot toekenning van het stemrecht aan de pandhouder kan in de statuten worden uitgesloten.

lid 4. De aandeelhouder die geen stemrecht heeft en de pandhouder die stemrecht heeft, hebben de rechten, die door de wet zijn toegekend aan de houder van met medewerking ener vennootschap uitgegeven certificaten van aandelen. De pandhouder die geen stemrecht heeft, heeft deze rechten indien de statuten dit bepalen en bij de vestiging of overgang van het pandrecht niet anders is bepaald.

lid 5. Artikel 195 van dit Boek en de statutaire bepalingen ten aanzien van de vervreemding en overdracht van aandelen zijn van toepassing op de vervreemding en overdracht van de aandelen door de pandhouder of de verblijving van de aandelen aan de pandhouder, met dien verstande dat de pandhouder alle ten aanzien van de vervreemding en overdracht aan de aandeelhouder toekomende rechten uitoefent en diens verplichtingen ter zake nakomt.

Lid 6 van art. 89 is ingevoend bij wet van 3 september 1992, Stb 1992, 458. 


\section{I.3.3 Mogelijkheid van verpanding van aandelen}

\subsubsection{Algemeen}

Pandrecht kan worden gevestigd op alle, overdraagbare, roerende goederen die geen registergoederen zijn. Voor een rechtsgeldige totstandkoming van een pandrecht dient aan een aantal voorwaarden te zijn voldaan. De voorwaarden voor een geldige vestiging van een pandrecht zijn gelijk aan de vereisten die gesteld worden aan de overdracht van goederen (art. 3:98 jo 84 BW).

Zo dient er voor het vestigen van een geldig pandrecht voldaan te zijn aan de vereisten van een geldige titel, beschikkingsbevoegdheid van de pandgever en een levering (art. 3:84 BW), danwel van een vestiging (art. 3:98 BW) bestaande uit een goederenrechtelijke overeenkomst van vestiging, gepaard gaande met een antal vestigingsformaliteiten. ${ }^{29}$ Een geldige titel kan bestaan uit een verbintenis $^{30}$ waarbij partijen afspreken dat er een pandrecht zal worden gevestigd op aandelen van de aandeelhouder (pandgever) tot meerdere zekerheid van de nakoming van een geldlening die door een derde (bank/pandhouder) is verstrekt aan de aandeelhouder (pandgever), danwel aan een derde.

Wil men rechtsgeldig aandelen kunnen verpanden dan dient men ten aanzien van die aandelen beschikkingsbevoegd te zijn. Dit betekent dat de pandgever rechthebbende moet zijn op de aandelen. Voor wat het derde vereiste betreft, het vereiste van de levering/vestiging, kan verwezen worden naar de artt. 3:237 en $239 \mathrm{BW} \cdot{ }^{31}$

Alvorens de wettelijke regeling van verpanding van aandelen in naamloze en besloten vennootschappen te bespreken, zal kort worden aangegeven welke vormen van pandrecht er bestaan.

Op vorderingen aan toonder kan een vuistpand of een bezitloos pand worden gevestigd. Van toepassing zijn art. 3:236 respectievelijk art. 3:237 BW.

29 Deze vestigingsformaliteiten zijn in het algemeen: a. voor beperkte rechten op register goederen, een notariële akte en inschrijving in de openbare registers (art. 3:89); b. voor beperkte rechten op roerende zaken, verschaffing van de feitelijke macht over de zaak (artt. 3:90/91); c. voor beperkte rechten op vorderingsrechten op naam, een akte en mededeling aan de schuldenaar (ar. 3:94), d. voor beperkte rechten op goederen die zelf moeten worden geleverd, een akte (art. 3:95). Voor de vestiging van een pandrecht gelden ten dele andere vereisten, zie de artikelen 3:237 en 239, waarover later meer. Overeenkomstig art. 3:81 lid 1 kan de vestiging van een beperkt recht ook plaatsvinden doordat de rechthebbende zijn recht overdraagt onder voorbehoud van een beperkt recht. In dit geval dienen zowel de vereisten voor overdracht van het grondrecht als die gesteld aan de vestiging van een beperkt recht te worden vervuld. Zie H.J. Snijders, E.B. Rank-Berenschot, Goederenrecht, nr. 471.

30 Die kan voortvloeien uit een overeenkomst maar ook uit de wet.

31 Deze problematiek zal worden behandeld in $\S \mathbf{~} \mathbf{5}$. 
De vestigingshandeling bij vuistpand geschiedt door het goed in de macht van de pandhouder of een derde te brengen. Bezitloos pand kan worden gevestigd door middel van een authentieke akte of een geregistreerde onderhandse akte. Bij bezitloos pand wordt het verpande goed niet uit de macht van de pandgever gebracht.

De artt. 3:236 lid 2 en 239 BW geven een regeling voor de verpanding van vorderingen op naam. Op een vordering op naam kan, enerzijds, een openbaar pand worden gevestigd. Dit geschiedt door, ondertekening van, een daartoe bestemde akte en een mededeling van het feit van vestiging aan de debiteur van de verpande vordering. ${ }^{32}$ Anderzijds kan een stil pand worden gevestigd op vorderingen op naam. De vestigingshandeling vindt alsdan plaats door een authentieke of geregistreerde onderhandse akte, zonder mededeling aan de debiteur van de verpande vordering. ${ }^{33}$

\section{I.3.3.2 Naamloze vennootschap}

Bezien wij de wettelijke regeling betreffende verpanding van aandelen in een naamloze vennootschap, dan blijkt dat de aandelen in beginsel voor verpanding vatbaar zijn. ${ }^{34}$ De wet maakt evenwel een onderscheid tussen de bevoegdheid tot verpanding van toonderaandelen en verpanding van aandelen die op naam zijn gesteld.

De bevoegdheid tot verpanding van aandelen aan toonder kan door de statuten van de vennootschap nimmer worden beperkt of uitgesioten. Aandelen op naam in een (al dan niet besloten) naamloze vennootschap kunnen eveneens worden verpand. Ten aanzien van deze aandelen bepaalt de wet dat de bevoegdheid tot verpanding statutair kan worden beperkt, danwel kan worden uitgesloten. Zoals reeds eerder werd opgemerkt is, volgens de wetgever, de maatschappelijke behoefte aan pandrecht op aandelen minder zwaarwegend en van andere aard dan de vestiging van vruchtgebruik op aandelen, dat veelal geschiedt ter uitvoering van een legaat ter voorziening in het onderhoud van de langstlevende echtgenoot. ${ }^{35}$ Daarom dient bij verpanding van aandelen het vennootschappelijk belang doorslaggevend te zijn. Evenwel met dien verstande dat toonderaandelen zozeer

32 Zie art. 3:94 jo $98 \mathrm{BW}$; de akte behoeft geen authentiek of geregistreerd karakter te hebben, zie H.J. Snijders, E.B. Rank-Berenschot, Goederenrecht, nr. 347.

33 Zie voor de mogelijkheid en wijze van vestiging van een pandrecht op aandelen op naam, $\$$ I.5. De mogelijkheid en wijze van vestiging van een stil pandrecht op aandelen op naam wordt beschreven in $\$$ I.5.2.1.

34 Zie ook Handboek (1992), no. 184.

35 De mogelijkheid van het vestigen van vruchtgebruik van aandelen kan dan ook niet statutair worden afgesneden voor wat betreft aandelen aan toonder en - al dan niet geblokkeerde aandelen op naam. 
gelijk gesteld zijn aan lichamelijke roerende goederen, dat hier verpanding steeds mogelijk moet zijn. ${ }^{36}$

Met verpanding van toonderaandelen zijn, in beginsel, geen vennootschappelijke belange ${ }^{37}$ gemoeid die in het gedrang kunnen komen. Nu de overdracht van deze aandelen vrij is, kan verpanding van deze aandelen ongelimiteerd plaatsvinden.

Bij aandelen op naam echter moet het mogelijk zijn dat de statuten verpanding verbieden, evenals het mogelijk is bij vorderingen op naam overeen te komen dat zij niet verpand kunnen worden. Het vennootschappelijk belang waarover hier gewaakt dient te worden, is het besloten karakter van de vennootschap. ${ }^{38}$ We spreken dan over een naamloze vennootschap met - een bepaalde hoeveelheid aandelen op naam die statutair geblokkeerd zijn (de besloten naamloze vennootschap), alsmede over een naamloze vennootschap in wiens statuten een $\mathrm{x} \%$ regeling, veelal in combinatie met een certificeringsregeling, is opgenomen. Geheel bevredigend is deze regeling mijns inziens niet. Men stelle zich de volgende situatie voor. In een naamloze vennootschap zijn de aandelen op naam statutair geblokkeerd. De statuten bepalen dat de geblokkeerde aandelen slechts aan bepaalde personen vrij kunnen worden overgedragen..$^{39}$ De statuten bepalen voorts dat verpanding van aandelen op naam niet toegestaan is. Dit leidt tot de naar mijn mening vreemde situatie dat de op naam luidende aandelen niet kunnen worden verpand aan een persoon, aan wie de aandelen wel vrijelijk (zonder goedkeuring door, danwel voorafgaande aanbieding aan de overige aandeelhouders) in eigendom overgedragen kunnen worden. Wie rechtsgeldig het meerdere mag, mag kennelijk in dit geval dus niet het mindere.

36 TK 12897 , no 3, p.4.

37 "Als vennootschappelijk belang kan gelden de resultante van afweging van belangen van hen die bij de vennootschappelijke werkzaamheden zijn betrokken .(..) De grootte van de vennootschap, de aard van haar activiteiten, de scheiding van management en aandeelhouderschap zijn factoren die het "vennootschappelijke belang" mede bepalen." aldus Handboek (1992), nr. 231. Mijns inziens dient, in het licht van het vorenstaande, het begrip "vennootschappelijk belang" in geval van verpanding van aandelen eng te worden geinterpreteerd. Daarom ben ik dan ook van mening dat verpanding van aandelen slechts dan uitgesloten kan worden indien de verpanding leidt tot doorbraak van het besloten karakter van de vennootschap. Dit zal dus slechts dan kunnen voorkomen in het geval waarin sprake is van een besloten vennootschap, van een besloten naamloze vennootschap dan wel van een open naamloze vennootschap die naast gewone aandelen, geblokkeerde aandelen op naam heeft uitgegeven (bijv. preferente beschermingsaandelen).

38 In Deel II (\$ II.7. e.v.) zal nader worden ingegaan op de gevolgen die van het vestigen van een pandrecht op aandelen heeft voor het besloten karakter van de vennootschap.

39 Regeling conform art. 87 jo 195 lid 1 BW. Opgemerkt dient te worden dat de kring waarbinnen aandelen vrijelijk kunnen worden overgedragen veelal statutair uitgesloten dan wel beperkt zal zijn. Met betrekking tot machtsaandelen zal zo'n vrije kring vrijwel altijd ontbreken dan wel beperkt zijn tot de houders van die machtsaandelen. 
Het statutaire verbod tot verpanding kan ook worden beperkt tot een bepaald soort aandelen ${ }^{40}$ of afhankelijk worden gemaakt van de goedkeuring van een bepaald, statutair aangewezen, vennootschapsorgaan. ${ }^{41}$

\section{I.3.3.3 De besloten vennootschap}

Op aandelen kan een pandrecht worden gevestigd, indien de statuten niet anders bepalen. Aldus art. 198 lid 1 BW. De leden 1 van de artt. 198 en 89 BW verschillen redactioneel en inhoudelijk van elkaar. ${ }^{42}$ Voor wat betreft het eerste verschil is dat niet zo vreemd, een besloten vennootschap kent nu eenmaal geen aandelen aan toonder.

Echter ook ten aanzien van de regeling van verpanding van aandelen op naam lopen de wettelijke bepalingen van de naamloze en besloten vennootschap, in ieder geval tekstueel, uiteen.

Op aandelen op naam in een besloten vennootschap kan pandrecht worden gevestigd, indien de statuten niet anders bepalen; aandelen op naam in een naamloze vennootschap kunnen worden verpand voor zover de statuten niet anders bepalen. In de praktijk betekent dit dat de statuten van zowel een naamloze als een besloten vennootschap verpanding van aandelen op naam kunnen beperken danwel uitsluiten of verbieden. ${ }^{43}$

Naast dit verschil in formulering van beide artikelen is er nog een ander verschil te bespeuren, namelijk in de leden 3 van genoemde artikelen. Statutair kan worden afgeweken van het bepaalde in lid 3 . In de statuten kan dus worden bepaald dat het stemrecht verbonden aan geblokkeerde aandelen op naam in een naamloze vennootschap vrijelijk, of onder bepaalde voorwaarden aan de pandhouder kan worden overgedragen. Bij de besloten vennootschap daarentegen kan de overgang van het stemrecht niet aan andere voorwaarden, dan die genoemd worden in art. 198 lid $3 \mathrm{BW}$, eerste en tweede volzin, worden gekoppeld. De bevoegdheid tot toekenning van het stemrecht aan de pandhouder kan slechts statutair worden uitgesloten. De redactie van de laatste volzin van de leden 3 van de artt. 89 en 198 BW verschilt duidelijk van elkaar. Kennelijk heeft de wetgever

40 Opgemerkt dient te worden dat dit deels een academische constructie is waar het gaat om de verpanding van prioriteitsaandelen en preferente aandelen. In de eerste plaats hebben deze aandelen veelal geen reële vermogenswaarde en in de tweede plaats verenigt het doel van de uitgifte van deze aandelen zich niet met een mogelijke verpanding ervan.

41 Rechispersonen, J.B. Huizink, aantekening 2 bij ant. 89 BW, p. 89-2. Bij de invulling van het begrip vennootschapsorgaan sluit ik aan bij de definitie gegeven in de Richtijnen 1986 . Onder het begrip vennootschapsorgaan worden verstaan: de algemene vergadering van aandeelhouders, de vergadering van houders van aandelen van een bepaalde soort, het bestuur, de raad van commissarissen en de gecombineerde vergadering van het bestuur en de raad van commissarissen.

42 Zie de gecursiveerde tekst in $\$ 1.3 .2$.

43 Zie J.V. Nolet, Vruchtgebruik en pandrecht op aandelen, WPNR 5352 (1976), p. 367. 
de opening willen scheppen de statutaire regeling van de overgang van stemrecht bij de NV minder rigide te houden dan bij de BV. De ratio van de strakke regeling bij de BV is naar mijn mening gelegen in de verplichte blokkering van aandelen bij deze vennootschapsvorm. Een vrije - of minder gecompliceerde overgang van het stemrecht aan personen die niet zonder goedkeuring deel kunnen gaan nemen in het samenwerkingsverband strookt niet met het, door de wetgever imperatief opgelegde, besloten karakter van de vennootschap. Deze discrepantie zal worden behandeld bij de beschrijving van de - mogelijke overgang van het stemrecht van de aandeelhouder/pandgever naar de pandhouder $\left(\S\right.$ I.6.). ${ }^{44}$

44 Een volgend verschil tussen de artt. 89 en 198 is het ontbreken van de bepaling in art. 89 lid 6 in art. 198. Op dit manco zal ik nader ingaan in $\$$ I.5.2.1. Bovendien bevalten de leden 4 van genoemde bepalingen verschillende slotzinnen. De ratio van deze deviatie zal worden toegelicht in $\S 1.7$. 



\section{I.4 Het in pand nemen van eigen aandelen}

In art. 89a BW lezen wij omtrent het in pand nemen van eigen aandelen door een naamloze vennootschap het volgende:

lid 1. De naamloze vennootschap kan eigen aandelen of certificaten daarvan slechts in pand nemen, indien:

a. de in pand te nemen aandelen volgestort zijn,

b. het nominale bedrag van de in pand te nemen en de reeds gehouden eigen aandelen en certificaten daarvan tezamen niet meer dan een tiende van het geplaatste kapitaal bedraagt, en

c. de algemene vergadering van aandeelhouders de pandovereenkomst heeft goedgekeurd.

lid 2. Dit artikel is niet van toepassing op aandelen en certificaten daarvan die een volgens de Wet toezicht kredietwezen ingeschreven kredietinstelling in de gewone uitoefening van het kredietbedrijf in pand neemt. Deze aandelen en certificaten blijven buiten beschouwing bij de toepassing van de artikelen 98 lid 2 onder b en 98 a lid 3.

Art. 89a is in Boek 2 BW opgenomen naar aanleiding van de Aanpassingswet Tweede EG-richtlijn. ${ }^{45}$

Het artikel is een uitwerking van art. $24^{46}$ van de Tweede EG-richtlijn. ${ }^{47}$ De bedoeling van art. 24 was een veronderstelde ongelijkheid weg te nemen om de beperkingen ten aanzien van de inkoop van eigen aandelen en certificaten van die aandelen te ontduiken door inpandneming in plaats van inkoop. ${ }^{48}$ De richtlijngever was van mening, dat inpandneming van eigen aandelen in het verlengde ligt van verkrijging van eigen aandelen. ${ }^{49} \mathrm{Hij}$ was dus kennelijk bevreesd dat de naamloze vennootschap door middel van executie van het pandrecht de aandelen zelf zou kunnen verkrijgen, waardoor de wettelijk toegelaten $10 \%$-grens voor aandelen in eigen bezit kan worden overschreden. Deze redenering overtuigt mij niet. In de eerste plaats kan een pandrecht slechts worden gevestigd indien de pandnemer een vordering heeft op de pandgever. In de tweede plaats kan worden

45 Wet van 15 mei 1981 tot aanpassing van de wetgeving aan de Tweede richtlijn van de Raad van de Europese Gemeenschappen inzake het vennootschapsrecht, Stb. 1981, 332, in werking getreden op 1 september 1981, Stb. 1981, 333.

46 " 1 . het in pand nemen van eigen aandelen door de vennootschap zelf, of door een persoon die in eigen naam maar voor rekening van de vennootschap handelt, wordt gelijkgesteld met verkrijging in de zin van de artikelen 19, 20, lid 1, 22 en 23.

2. De lid-Staten behoeven lid 1 niet toe te passen op de gewone bedrijfsuitoefening van banken en andere financiële instellingen."

47 Tweede richtlijn van de Raad der Europese Gemeenschappen van 13 december 1976 (77/91/EEG).

48 Rechtspersonen, J.B. Huizink, aantekening 2 bij art. 89a, p. 89a-3.

49 Handboek (1992), no. 184.1. 
opgemerkt, dat de naamloze vennootschap door executie van het pandrecht op de eigen aandelen niet van rechtswege rechthebbende wordt op die aandelen. ${ }^{50}$ Immers, indien de door de naamloze vennootschap in pand genomen eigen aandelen op naam luiden en door middel van een aanbiedingsregeling zijn geblokkeerd, zullen de te executeren aandelen eerst aan de mede-aandeelhouders aangeboden moeten worden alvorens de rechtspersoon zelf rechthebbende kan worden. ${ }^{51}$ De vrees, dat executie van in pand genomen eigen aandelen automatisch zou leiden tot frustratie van de $10 \%$-grens, is mijns inziens niet gegrond. De inpandneming van eigen aandelen raakt immers niet de realiteit van het vennootschappelijk kapitaal. ${ }^{52}$

Art. 89a BW geeft aan dat aandelen en certificaten van aandelen slechts met inachtneming van een drietal beperkingen door de vennootschap in pand kunnen worden genomen. De regeling van art. 89a BW is afgestemd op die van de artt. 98-98d BW betreffende de inkoop van eigen aandelen. Niet volgestorte aandelen mag de naamloze vennootschap niet in pand nemen en de in pand genomen eigen aandelen en de in pand te nemen eigen aandelen tellen mee bij de vraag of de grens van $10 \%$ van het geplaatste kapitaal is bereikt. Nietig is de handeling waarbij eigen aandelen in pand genomen worden in strijd met de bepalingen van

50 Voor wat betreft de besloten vennootschap kan deze redenering nog krachiger worden verdedigd, daar bij een evenuele executie van de in pand genomen eigen aandelen de statutaire blokkeringsbepaling voor de overdracht van aandelen dient te worden nageleefd en daarenboven in lid 6 van an. $195 \mathrm{BW}$ bepaald wordt dat de vennootschap slechts met instemming van de aandeelhouder(/pandgever) gegadigde kan zijn in het kader van een goedkeurings- dan wel aanbiedingsregeling.

51 Bij een blokkering door middel van een goedkeuringsregeling liggen de kaanen anders. Hier kan men verdedigen dat de naamloze vennootschap ten gevolge van de executie wel van rechtswege rechthebbende op de aandelen wordt. M.i. is een aparte goedkeuring van de algemene vergadering van aandeelhouders voor de overdracht van de aandelen niet vereist daar deze goedkeuring reeds impliciet werd verleend op het moment waarop de AVA haar goedkeuring gaf aan de pandovereenkomst (zie art. 89 lid 1 sub c BW). 
art. 89a lid $1 \mathrm{BW}$, onder a-c. ${ }^{53}$ Zoals vermeld in art. 89a lid 2 BW gelden de drie vereisten van lid 1 niet voor een krediet-instelling, voor zover het aandelen en certificaten betreft die zij in de gewone uitoefening van haar kredietbedrijf in pand neemt.

Het toepassingsgebied van de Tweede EG-richtlijn beperkt zich tot de naamloze vennootschap $^{54}$. Deze beperking wordt, volgens Van Hulle ${ }^{55}$, als belangrijk nadeel van de richtlijn gezien. Enkele Lid-Staten hebben de bepalingen van de richtlijn geheel of gedeeltelijk toepasselijk gemaakt op de besloten vennootschap. ${ }^{56}$ In Nederland trad bij besluit van 1 januari 1986 de Wet van 12 december 1985 , Stb. 656, houdende een nieuwe regeling voor het kapitaal van de besloten vennootschap, in werking. ${ }^{57}$ In de MvT behorende bij het wetsontwerp voor een nieuwe regeling voor het kapitaal van de besloten vennootschap met beperkte aansprakelijkheid lezen we de volgende passage:

"Het ontwerp geeft een nieuwe regeling voor de kapitaalbescherming en kapitaalverhoging van de besloten vennootschap met beperkte aansprakelijkheid. Deze nieuwe regeling sluit nauw aan bij de nieuwe regeling voor het kapitaal van de naamloze vennootschap die wordt voorgesteld in het aanhangige wetsontwerp 15304 tot aanpassing van de wet aan de tweede EEG-Richtlijn inzake het vennootschapsrecht.

De aanpassingswet aan de tweede Richtlijn geeft evenals de Richtlijn zelf alleen regelen voor de naamloze vennootschap. $\mathrm{Zij}$ bevat waarborgen voor schuldeisers tegen het niet bijeenbrengen van voldoende kapitaal en tegen uitholling van dit kapitaal ten gunste van aandeelhouders. De rechtsvorm van de naamloze vennootschap brengt immers mee dat zaken worden gedaan zonder dat de aandeelhouders persoonlijk aansprakelijk zijn voor de schulden van de n.v. Daar staat tegenover dat alle aandeelhouders samen moeten bijdragen in het vermogen van de n.v. Op dit vermogen hebben de schuldeisers van de n.v. verhaal. In beginsel mag dit vermogen, (...), niet aan aandeelhouders worden uitgekeerd totdat de n.v. wordt opgeheven. In al deze opzichten verschilt de b.v. niet wezenlijk van de n.v. Er is daarom alle reden om, nu de wettelijke bescherming van de schuldeisers van de n.v. wordt verbeterd, ook de bescherming van de schuldeisers van de b.v. te herzien. De

53 Zie $F$. Molenaar, Pandrecht, Mon. Nieuw BW, B12a, $2^{\text {c }}$ druk, 1991, p. 17. Voor de door de naamloze vennootschap in pand genomen eigen aandelen geeft de wet, in de artt. 98 lid 2 onder b, 98 lid 3, 118 lid 7 en 378 lid 4, verdere voorschriften. Deze voorschriften gelden, met uitzondering van art. 118 lid 7, niet voor het pandrecht dat de knedietinstelling in haar gewone bedrijfsuitvoering heeft verkregen, zie Handboek (1992), no. 184.1; F. Molenaar, Pandrecht, Mon. Nieuw BW, B12a, $2^{2}$ druk, 1991, p. 17/18.

54 Zie art. 1 van de Tweede EG-richtlijn. Zie ook J.H. Maschhaupt, P.M. Storm, De Tweede EEG-Richtijn inzake vennootschapsrecht, preadviezen, Zwolle 1978, p. 35.

$55 K$. van Hulle, De Harmonisatie van het vennootschapsrecht in de Europese Gemeenschap, in: Harmonisatie van Vennootschaps- en Effectenrecht; Ervaringen en vooruitzichten in Europa en de Verenigde Staten, Deventer 1988, p. 42.

56 Zie $K$. van Hulle, De Harmonisatie van het vennootschapsrecht in de Europese Gemeenschap, p. 42. Vgl. de 'National Reports' in: H.J. de Kluiver, W. van Gerven (eds.), The European Private Company?, 1995.

57 Stb. 1986; 3. 
regeling in dit wetsontwerp komt dan ook in grote mate overeen met de nieuwe regeling voor de n.v. De verschillen ten opzichte van de regeling voor de n.v. zijn beperkt tor enkele onderdelen waar de eigen aard van de besloten vennootschap een afwijking rechtvaardigt. ${ }^{\text {"ss }}$

Een van de verschillen in relatie tot de regeling voor de naamloze vennootschap is het ontbreken van een wettelijke bepaling voor het in pand nemen van eigen aandelen door de besloten vennootschap. In het oorspronkelijke ontwerp van wet $^{59}$ was in art. 198a BW een regeling opgenomen betreffende het in pand nemen van eigen aandelen. Het ontwerp-artikel luidde als volgt:

"1. De vennootschap kan eigen aandelen of certificaten daarvan slechts in pand nemen tot een tiende van het geplaatste kapitaal en mits de algemene vergadering van aandeelhouders de pandovereenkomst heeft goedgekeurd.

2. Dochtermaatschappijen van de vennootschap kunnen geen aandelen in haar kapitaal of certificaten daarvan in pand nemen.

3. Dit artikel is niet van toepassing op aandelen en certificaten daarvan die een volgens de Wet toezicht kredietwezen ingeschreven kredietinstelling in de gewone uitoefening van het kredietbedrijf in pand neemt. Deze aandelen en certificaten blijven buiten beschouwing bij de toepassing van artikel 207 , lid 2 onder b."

In de $\mathrm{MvT}^{60}$ wordt naar aanleiding van dit artikel opgemerkt dat de regeling voor het in pand nemen van eigen aandelen door de besloten vennootschap, in vergelijking met de regeling voor de naamloze vennootschap, vereenvoudigd is. De kans op ontduiking van de inkoopbepalingen door het in pand nemen van eigen aandelen wordt niet groot geacht en in het geval waarin dit wel geschiedt zal deze ontduiking door de rechter worden gesanctioneerd. In de eerste Nota van Wijzigingen ${ }^{61}$ werd het voorgestelde art. 198a BW, zoals hiervoor weergegeven, dan ook geschrapt. Naar aanleiding hiervan geeft de minister de volgende toelichting:

"Bij nader inzien heeft het invoeren van bijzondere regels voor het in pand nemen van eigen aandelen inderdaad, (...), geen nut. Beperkingen van de mogelijkheid daartoe strekt de vennootschap noch haar schuldeisers ten voordele. De bepaling is ontworpen uit vrees dat eigen aandelen onder dusdanige voorwaarden in pand worden genomen, dat dit als een verkapte verkrijging moet worden aangemerkt. Op elke verkrijging, ook de verkapte, is evenwel artikel 207 van toepassing. Daamaast bestaat aan het voorgestelde artikel 198a, dat ook zou gelden voor de gewone gevallen dat achter pand geen verkrijging schuilgaat, geen behoefte. ${ }^{n 62}$

58 TK 16551, nr. 3.

59 TK 16551 , nr. 2.

60 TK 16551 , ar. 3, punt 6.

61 TK 16551, nr. 7.

62 J.M.M. Maeijer, Wetsgeschiedenis, IXr - Art. 198a - 2. 
De Nederlandse wetgever heeft dus geen voorziening getroffen met betrekking tot het in pand nemen van eigen aandelen door de besloten vennootschap. Wel geldt voor haar het verbod tot het nemen van eigen aandelen. ${ }^{63}$ Hieronder valt mijns inziens niet het in pand nemen van eigen aandelen. Door het nemen van eigen aandelen wordt de besloten vennootschap rechthebbende op die aandelen, door het in pand nemen van eigen aandelen verkrijgt de BV een zekerheidsrecht op de aandelen en wordt zij slechts houdster van die aandelen voor de pandgever/aandeelhouder.

Art. 207 BW bepaalt onder meer dat een besloten vennootschap eigen aandelen om baat kan verkrijgen indien:

(...)b. het nominale bedrag van de te verkrijgen en de reeds door de vennootschap en haar dochtermaatschappijen tezamen gehouden aandelen in haar kapitaal niet meer dan de helft van het geplaatste kapitaal bedraagt,(...)

Indien de besloten vennootschap dus in principe tot de grens van $50 \%$ van haar geplaatste kapitaal eigen aandelen mag verkrijgen, zal het zeker toelaatbaar zijn dat de besloten vennootschap haar eigen aandelen in ieder geval tot die $50 \%$ grens in pand mag nemen. Mijns inziens kan de vennootschap nog verder gaan. Is er een argument te bedenken tegen het bedingen van zekerheid bestaande uit een recht van pand op een $75 \%$ - of zelfs een $100 \%$ pakket aandelen voor een door de vennootschap aan een aandeelhouder verstrekte lening? ${ }^{64}$ Door het bedingen van deze zekerheid worden de belangen van de schuldeisers niet geschaad. De kapitaalrealiteit van de vennootschap komt hierdoor niet in het geding. ${ }^{65}$ In navolging van Honée ${ }^{66}$ zou ik er meer voor voelen een wettelijke regeling op te nemen die het verstrekken van leningen door de vennootschap aan haar aandeelhouders beperkt. Immers, door het verstrekken van leningen kan de kapitaalrealiteit en daarmee de bescherming van de financiële belangen van vennootschapscrediteuren, onder omstandigheden, wel in het geding komen.

Aan het einde van deze paragraaf een opmerking over het stemrecht en de in pand genomen eigen aandelen. In het zesde lid van art. $228 \mathrm{BW}$ wordt bepaald dat de vennootschap of een dochtermaatschappij daarvan geen stem kan uitbren-

63 Art. 205 BW: "De vennootschap kan geen eigen aandelen nemen."

64 Men lette op het bepaalde in de eerste twee leden van ant. 207c BW.

65 Art. $207 \mathrm{BW}$ biedt, zoals reeds eerder opgemerkt door de minister van justitie, een wapen tegen het gebruik van het in pand nemen van eigen aandelen als verkapte vorm van verkrijging van aandelen door de vennootschap.

66 H.J.M.N. Honée, Het gewijzigde ontwerp aanpassingswet tweede EEG-Richtijn (slot), De NV 58 (1980), p. 138. Zie omtrent het verstrekken van leningen door de vennootschap aan aandeelhouders ook H.P.J. Ophof, Dient art. 2:98c/207c BW te worden gewijzigd c.q. geschrapt? in: 'Knelpunten in de vennootschapswetgeving', P. van Schilfgararde e.a., Kluwer, Deventer 1995, p. 63 e.v. 
gen voor een aandeel waarop zij een pandrecht heeft. ${ }^{67}$ Zou dit wel mogelijk zijn dan gaat de idee van 'power and control' volledig teloor.

67 Voor de naamloze vennootschap wordt hetzelfde bepaald in art. 118 lid 7 BW. 


\section{I.5 Vestiging van pandrecht op aandelen}

Ten aanzien van de wijze van vestiging van een pandrecht op aandelen in een naamloze vennootschap dient onderscheid te worden gemaakt tussen aandelen die aan toonder luiden en aandelen die op naam zijn gesteld.

\section{a. Aandelen aan toonder}

Met betrekking tot de vestiging van pandrecht op een aandeel aan toonder zwijgt Boek $2 \mathrm{BW}$. We zijn dus genoodzaakt ten aanzien van deze materie terug te koppelen naar Boek $3 \mathrm{BW}$ en wel naar de bepalingen omtrent de vestiging van een pandrecht op een recht aan toonder.

Art. 3:236 lid 1 BW bepaalt dat een pandrecht op een recht aan toonder wordt gevestigd door het toonderpapier in de macht van de pandhouder te brengen danwel in de macht van een derde omtrent wie partijen zijn overeengekomen. Art. 3:237 lid $1 \mathrm{BW}$ leert ons dat, naast het vuistpand van art. 3:236 lid $1 \mathrm{BW}$, ook een bezitloos (stil) pandrecht op een recht aan toonder (lees: aandeel aan toonder), kan worden gevestigd. ${ }^{68}$ De vestiging geschiedt dan door middel van een authentieke of geregistreerde onderhandse akte, zonder dat het toonderpapier uit de macht van de pandgever wordt gebracht. Het pandrecht ontstaat niet eerder dan op het moment waarop de authentieke akte is ondertekend of de onderhandse akte van een vaste dagtekening is voorzien door de registratie-afdeling van het belastingkantoor. ${ }^{69}$

\section{b. Aandelen op naam}

Vestiging van een pandrecht op een aandeel op naam geschiedt conform de regeling voor de levering van een aandeel op naam, aldus art. 86/196 lid 1 BW. Boek 2 BW geeft een lex specialis voor de levering van aandelen op naam (artt. 86/196 BW). Ware dit niet het geval dan zou men de regeling van art. 3:236 lid 2 jo $94 \mathrm{BW}$, betreffende levering van een vorderingsrecht op naam (cessie), analoog moeten toepassen. Als vereisten voor de levering van een vordering op naam gelden een - onderhandse danwel notariële-akte van cessie die de goederenrechtelijke overeenkomst van overdracht dient te vermelden en een mededeling aan de debiteur van de vordering. De levering is eerst dan voltooid indien aan de

68 Zie met betrekking tot het begrip bezitloos pand/stille verpanding W.H.M. Reehuis, Stille verpanding van roerende zaken en vorderingen volgens het NBW, diss.

69 Asser-Mijnssen, Zakenrecht ШI, nrs. 67/68. 
debiteur is medegedeeld dat ter zake van de betreffende vordering een akte van cessie is opgemaakt.

De artt. 86/196 BW wijken af van de lex generalis van art. 3:94 BW.

Met de inwerkingtreding van de wet van 3 september $1992^{70}$ is een aanzienlijke verandering gebracht in de regeling van de overdracht van aandelen in een besloten vennootschap en aandelen op naam in een naamloze vennootschap. ${ }^{71}$ Inherent aan de wijziging van de regeling van overdracht zijn de mutaties in de regeling aangaande het vestigen van een pandrecht op aandelen op naam. Deze wetswijziging is de resultante van een jarenlange discussie in politiek en wetenschappelijk Nederland. Ik zal kort op de historie van deze wetswijziging en de factoren die daaraan ten grondslag lagen ingaan. ${ }^{p}$

70 Houdende wijziging van de regeling van de overdracht van aandelen op naam in naamloze vennootschappen en besloten vennootschappen met beperkte aansprakelijkheid. De wet is in werking getreden op 1 januari 1993.

71 Op p. 3 van de MvT, TK 21 155, nr. 3 wordt door de Minister van Justitie opgemerkt: "In het thans voorgestelde stelsel wordt in de leveringsvereisten van aandelen volgens het bepaalde in de artikelen 86 en 196 van Boek 2 BW (...) geen verandering gebracht. Er worden ten hoogste twee constitutieve eisen gesteld: akte en aanbieding ter registratie daarvan." Mijns inziens is dit niet het enige gevolg wat de wetswijziging met zich brengt, hierover meer in § I.5.1. e.v.

72 Zie omtrent de wijziging van de regeling van de overdracht van aandelen op naam in naamloze en besloten vennootschappen: S.E. Eisma, Verkrijging van aandelen op naam na invoering van het Derde Misbruikontwerp. WPNR 5763 (1985), p. 773 e.v.; W.J. Slagter, Levering van aandelen op naam en het derde misbruik-voorstel, TVVS 1986, p. 13 e.v.; S.M. van Steenbergen, De levering van aandelen op naam, TVVS 1987, p. 93 e.v.; P.J. Dortmond, Het advies van de Commissie Vennootschapsrecht inzake overdracht van aandelen, de Naamloze Vennootschap 65 (1987), p. 49 e.v.; W.P. Sikkelerus, Misbruik van rechtspersonen (overdracht van aandelen), M.B.B. 1987, p. 117 e.v.; H.J. Steinvoort, Het congres 'Aandelen', TVVS 1988, p. 189 e.v.; $M$. van Olffen, Levering aandelen op naam, Bank- en Effectenbedrijf 1988, p. 273 e.v.; J.E.D.M. Thielen, Levering van aandelen op naam, nu en straks, TVVS 1988,p. 33 e.v.; M.J.A. van Mourik, Verwikkelingen rond aandelen, WPNR 5877 (1988), p. 323 e.v.; S.E. Eisma, Opnieuw: Verkrijging van aandelen op naam, WPNR 5932 (1989), p. 573 e.v.; Advies van het Nederlands Genootschap van Bedrijfsjuristen inzake het wetsvoorstel Wijziging van de regel van de overdracht van aandelen op naam, NV 67 (1989), p. 185 e.v.; W.J. Slagter, Levering van aandelen op naam, NV 67 (1989), p. 196 e.v.; W.C.L. van der Grinten, Overdracht van aandelen op naam, WPNR 5966 (1990), p. 410 e.v.; F.K. Buijn, De overdracht van aandelen op naam in de praktijk, WPNR 5966 (1990), p. 412 e.v.; W.J. Slagter, Levering van aandelen op naam, WPNR 5966 (1990), p. 415 e.v.; W. Vermeend, Overdracht van aandelen op naam, WPNR 5966 (1990), p. 419 e.v.; H.J.M.N. Honée, De notaris als vennootschappelijk huismeester, NV 68 (1990), p. 93 e.v.; H.P.J. Ophof, Overdracht van aandelen op naam, TVVS 1991, p. 277 e.v.; G.M. ter Huurne, Relativiteit en levering van aandelen op naam in rechtsvergelijkend perspectief, TVVS 1991, p. 314 e.v.; Th.C.M. Hendriks-Jansen, Vennootschapswetgeving 21 155 - Wijziging in de regeling van de overdracht van aandelen op naam in naamloze en besloten vennootschappen met beperkte aansprakelijkheid, NV 70 (1992), p. 63; W.C.L. van der Grinten, 
Tijdens de behandeling van het wetsvoorstel betreffende de Derde anti-misbruikwet (wetsontwerp wijziging van bepalingen van het Burgerlijk Wetboek en de Faillissementswet in verband met de bestrijding van misbruik van rechtspersonen) ${ }^{73}$ werden de omstandigheden geschapen waarbinnen het zaad van de huidige regeling voorzichtig ontkiemde. Bij de behandeling van dit wetsontwerp werd door Vermeend, Van der Burg en De Grave een amendement ingediend dat de wijze van levering van aandelen op naam aanzienlijk zou veranderen. In het amendement werd voorgesteld dat voor de levering, uitgifte en toedeling van een aandeel op naam alsmede de vestiging van een beperkt recht daarop voortaan de eis van een geregistreerde akte zou worden gesteld. ${ }^{74}$ Als argument werd door de indieners van het amendement aangevoerd dat het eisen van een geregistreerde akte bij zou dragen aan misbruikbestrijding. De idee achter de geregistreerde akte was dat op die manier meer helderheid kon worden gebracht in de veelal onzicht-

Levering van aandelen op naam, NV 70 (1992), p. $25 ; M$. van Olffen, Uitgifte en overdracht van aandelen op naam, amendementen aanvaard, JBN 1992, p. 6 e.v.; D.F.M.M. Zaman, Misbruik + rechtszekerheid $=$ notariële aandelenoverdracht, Bb 1992, p. 45 e.v.; W.J. Slagter, Levering van aandelen op naam, TVVS 1992, p. 94 e.v.; P.M. Storm, Overdracht van aandelen op naam. Het klopt nog steeds niet, TVVS 1992, p. 95 e.v.; $B$. Wessels, Levering van aandelen op naam: onduidelijk wetsvoorstel, NV 70 (1992), p. 86 e.v.; C.M. Grundmann, Notariēle akte vereist voor levering van aandelen op naam, Bb 1992, p. 190 e.v. Zie voor een uitvoerige beschrijving van de totstandkoming van het wetsvoorstel $T$. Blokland, $M$. van Olffen, Uitgifte, verkoop en levering van (beperkte rechten op) aandelen op naam, Law \& Practice Publishers, Deventer 1992, p. 16 e.v.; C.E.M. van Steenderen, J.C.G. ten Brink, Uitgifte en levering van aandelen op naam, TVVS 1992, p. 303 e.v.; $M$. van Olffen, Uitgifte en levering van (beperkte rechten op) aandelen op naam, WPNR 6073 (1992), p. 920 e.v.; M.Ph. van Sint Truiden, Nieuwe regeling van overdracht van aandelen op naam en de vestiging van een pandrecht daarop per 1 januari 1993, NTBR 1993, p. 29 e.v.; J.J.A. Hamers, Nieuwe regeling van overdracht van aandelen op naam en de vestiging van pandrecht daarop. De Notarisklerk 1993, p. 25 e.v.; S.H.M.A. Dumoulin, Het legitimatieprobleem bij overdracht van aandelen op naam, TVVS 1994, p. 29 e.v.; $M$. van Olffen, D.F.M.M. Zaman, Nieuwe bepalingen omtrent uitgifte en levering van aandelen op naam, Preadvies van de Vereeniging 'Handelsrecht', Zwolle 1994. Zie voor een rechtsvergelijkend onderzoek op het terrein van de levering van aandelen op naam; G.M. ter Huume, Nieuwe regels voor de levering van aandelen op naam, diss. 1994. Zie ook (beknopt) $M$. van Olffen, Overdracht van aandelen op naam in overige EG-Lidstaten, alsmede in Oostenrijk, Turkije en Zwitserland, WPNR 5966 (1990), p. 417 e.v. Zie verder (algemeen) $M$. Kupperman, E.J. van Garderen, Notariēle aandelen-levering en -uitgifte een enquête, NV 73 (1995), p. 114 e.v. (Met naschrift van D.F.M.N. Zaman); G.M. ter Huume, Notariële akte en aandeelhoudersregister bij emissie en levering van aandelen op naam, NV 73 (1995), p. 119 e.v.; $M$. van Olffen, Constateren van en werken met een gebrekkige uitgifte en levering van aandelen op naam, NV 73 (1995), p. 123 e.v.; J.J.A. Hamers, Levering van aandelen op naam, in: Dossier Ondememingsrecht '96, nr. 22 1995, p. 12 e.v..

73 TK 16631.

74 TK 16 631, nrs. 29 en 31 (wijziging van de artikelen 86 en $196 \mathrm{BW}$ ). 
bare aandelentransacties. Door registratie van de akte zou bij de overheid bekend worden wie eigenaar van de aandelen wordt. ${ }^{75}$

Als tweede argument voor het invoeren van een geregistreerde akte als constitutief vereiste voor overdracht van aandelen op naam wordt - zij het niet met zoveel woorden - het waarborgen van de rechtszekerheid genoemd.

\footnotetext{
"Daarmee (registratie van de akte; $\mathrm{JH}$ ) wordt zoveel mogelijk voorkomen dat aandelenoverdrachten niet geldig tot stand komen, omdat bijvoorbeeld de erkenning of betekening achterwege is gebleven of niet bewezen kan worden dat afgifte van de akte aan de vennootschap is geschied. ${ }^{n 76}$
}

Deze, bij amendement, voorgestelde regeling zag zich niet gevrijwaard van de nodige kritiek uit de rechtsgeleerde literatuur. ${ }^{\pi}$ Tevens uitte de Eerste Kamer hevige kritiek. ${ }^{78}$ De kritiek was voornamelijk gericht op de relatieve werking van de levering. Dit wil zeggen dat de geregistreerde akte van levering een eigendomsoverdracht ten gevolg zou hebben die niet automatisch zou gelden in de verhouding tussen de nieuwe aandeelhouder en de vennootschap. Wil de overdracht tegenover de vennootschap rechtskracht verkrijgen dan dient deze overdracht eerst aan de vennootschap te worden betekend, danwel schriftelijk door de vennootschap te worden erkend. ${ }^{79}$ Naar aanleiding van deze kritiek is dit voorstel niet in werking getreden. De derde anti-misbruikwet is dan ook in delen ingevoerd. De bepalingen uit deze wet die geen betrekking hadden op de wijze van levering van aandelen op naam zijn op 1 januari 1987 in werking getreden. ${ }^{80}$ In 1989 werd aan de hand van het oude ontwerp een nieuw voorstel voor de regeling voor levering van aandelen op naam ingediend. ${ }^{81}$ In dit voorstel bleef de eis van de geregistreerde akte behouden. Dit voorstel, dat opnieuw geamendeerd werd door Vermeend en Van der Burg met de regeling dat voor een

75 De vraag of de voorgestelde regeling inderdaad gezien kan worden als een middel tot fraudebestrijding wordt in de literatuur algemeen ontkennend beantwoord, zie o.a. Handboek (1992), nr. 179, p. 269; W.P. Sikkelerus, Misbruik van rechtspersonen (overdracht van aandelen), M.B.B. 1987, p. 120.

76 TK 16631, nr. 31, p. 4.

77 Zie onder andere W.C.L. van de Grinten, NV 70 (1992); M.J.A. van Mourik, WPNR 5877 (1988); S.E. Eisma, WPNR 5932 (1989); W.J. Slagter, TVVS 1992.

78 Zie TK 16631 , nr. 27a, p. 13-15, 18-20; nr. 27b, p. 27-36; nr. 27d, p. 3-7; nr. 27e, p. 4-7.

79 Zie TK 16631 , nr. 31, p. 1, art. 86 lid 3: "De levering werkt tegenover de vennootschap eerst vanaf het tijdstip waarop zij overeenkomstig het bepaalde in dit lid aan haar is medegedeeld." Zie ook S.M. van Steenbergen, TVVS 1987, p. 94. Schrijver geeft nog een tweede bezwaar weer namelijk het feit dat in (het bij amendement voorgestelde) art. 86 lid 7 wordt bepaald dat in geval van levering van niet-volgestorte aandelen de dag van levering in het aandeelhoudersregister moet worden aangetekend, terwijl, waar het de BV betreft, een soortgelijke regeling ontbreekt in art. 196.

80 Wet van 24 november 1986 , Stb. 585.

81 TK 21 155, nrs. 1-2. 
rechtsgeldige overdracht een notariële akte vereist is ${ }^{82}$, heeft uiteindelijk geleid tot de huidige regeling van de levering van (en de vestiging van beperkte rechten op) aandelen op naam. Na enkele opmerkingen gemaakt te hebben over de oude situatie, zullen de nieuwe bepalingen nader besproken worden.

Voor de inwerkingtreding van deze nieuwe bepalingen werd voor de vestiging van een pandrecht op een aandeel op naam vereist, een tussen partijen opgemaakte akte van verpanding. De vestiging van het pandrecht kon, parallel aan de regeling van levering van een aandeel op naam, op twee verschillende wijzen tot stand komen: door middel van de betekening van de akte aan de vennootschap of door een schriftelijke erkenning ${ }^{83}$ van de vestiging door de vennootschap op grond van overlegging van de akte aan de vennootschap.

Over de betekenis van de term 'overlegging' in de betreffende wetsbepaling liepen de meningen uiteen. Van Schilfgaarde ${ }^{84}$ verdedigde dat onder 'overlegging van de akte' niet dient te worden verstaan de afgifte ervan. Aan het voorschrift is volgen hem voldaan wanneer een door partijen of een notaris gewaarmerkte fotokopie ter inzage wordt gegeven. Voor de hand ligt dat erkenning plaatsvindt door een desbetreffende aantekening op het overgelegde stuk. Dit kan dan dienen als bewijsstuk dat de akte inderdaad is overlegd. Dit laatste acht Van Schilfgaarde weer van belang, daar overlegging van de akte een constitutief vereiste is. Maeijer ${ }^{85}$ is eveneens deze mening toegedaan; de overlegging is een essentiële voorwaarde voor de erkenning en vormt aldus (mede) een constitutief vereiste voor de rechtsgeldigheid van de overdracht. Analoog kunnen wij dit toepassen op de overlegging van de akte van vestiging van pand. Van der Grinten is een andere mening toegedaan. Hij acht de erkenning geldig, zelfs indien geen overlegging heeft plaatsgevonden. ${ }^{86}$

82 TK 21155 , nr. 17.

83 De erkenning dient te geschieden door een vertegenwoordigingsbevoegde persoon. Erkenning door een niet tot vertegenwoordiging bevoegde heeft geen effect; zie HR 17 september 1982, NJ 1983, 195, nt. J.J.M. Maeijer (Sterk Baksteen); Slagter spreekt, voor wat de vestiging betreft, van eisen met betrekking tot de zakelijke overeenkomst (vormvoorschriften), Compendium, $6^{\mathrm{C}}$ druk, § 53.

$84 P$. van Schilfgaarde, Van de BV en de NV, $8^{\circ}$ druk, p. 101; Vergelijk Handboek (1989), nr. 179.

85 J.M.M. Maeijer, annotatie HR 17 september 1982, NJ 1983, 195 (Sterk Baksteen).

86 Handboek (1989) no. 179: De wetgever heeft slechts duidelijk willen maken dat de vennootschap overlegging van de akte behoort te vragen teneinde onjuiste boeking in de registers te voorkomen. De erkenning is een verklaring van de vennootschap dat haar de overdracht bekend is. Deze erkenning doet de geldigheid van de overdracht niet vaststaan ook niet tegenover de vennootschap. Van der Grinten wil aannemen dat de erkennende vennootschap die alsnog de geldigheid van de overdracht wil betwisten, de bewijslast heeft dat de overdracht niet geldig is (lees voor overdracht, akte van vestiging van pandrecht). Anders W.C.L. van der Grinten, Overdracht van aandelen op naam, WPNR 5966 (1990), p. 410. Mijns inziens hoeft de 


\section{I.5.1 De nieuwe regeling}

Sinds 1 januari 1993 gelden voor de levering van een aandeel op naam en voor de levering ${ }^{87}$ van een pandrecht op een aandeel op naam andere vereisten. De nieuwe regeling kan als volgt worden samengevat.

Voor de levering van een aandeel op naam in een besloten alsmede in een naamloze vennootschap ${ }^{88}$ en voor de levering van een pandrecht op aandelen op naam is een notariële akte vereist waarbij de betrokkenen partij zijn. De notariële akte is een constitutief vereiste voor een rechtsgeldige levering van aandelen op naam (en vestiging van een beperkt recht daarop). De akte dient opgemaakt te worden ten overstaan van een in Nederland standplaats hebbende notaris. ${ }^{89}$

Voor de uitgifte van aandelen die bij de oprichting worden geplaatst is geen afzonderlijke akte vereist. De oprichting van de vennootschap, waarbij de aandelen worden uitgegeven, geschiedt immers reeds bij notariële akte. Voor latere uitgifte van aandelen is $z^{\prime}$ 'n akte wel vereist. ${ }^{90}$

$86 \rightarrow$

overlegging niet te allen tijde gezien te worden als een constitutief vereiste voor een rechtsgeldige overdracht. Men kan zich immers het geval voorstellen waarin een bestuurder die tevens enig aandeelhouder is zijn aandelen wenst over te dragen dan wel wil verpanden. In dit geval kan men moeilijk vasthouden aan het principe dat in geval er geen overlegging van de akte heeft plaatsgevonden er geen erkenning door de vennootschap is geweest en dus niet gesproken kan worden van een rechtsgeldige overdracht (vestiging van een pandrecht).

87 De wet spreekt van "levering van pandrecht op een aandeel op naam", de term vestiging is in het betreffende lid van art. 86/196 BW komen te vervallen. Dit wordt in de NvW, TK 21 155, nr. 7, p. 4 als volgt toegelicht: "In de terminologie en het systeem van het Nieuwe B.W. omvat < <levering > > de feitelijke handelingen die vereist zijn voor vestiging, overdracht, afstand en toedeling van rechten. Levering is dus een algemeen begrip dat zowel op de overdracht van aandelen als de vestiging van beperkte rechren daarop betrekking kan hebben."

88 Met uizzondering van de levering van aandelen op naam of een beperkt recht daarop in een naamloze vennootschap, waarvan aandelen of certificaten van aandelen zijn toegelaten, dan wel spoedig zullen worden toegelaten tot de officiële notering van een gereglementeerde effectenbeurs; zie art. $88 \mathrm{c} \mathrm{BW}$.

89 Hiermede komt dus vast te staan dat het niet om een authentieke notariële akte gaat. Het ontbreken van authenticiteit staat niet in de weg aan een rechtsgeldige overdracht van de aandelen. Zie ook G.M. ter Huume, diss. p. 185.

90 In geval van een toekenning van aandelen bij een juridische fusie geldt de verplichting van de notarièle akte evenmin. Bij een juridische fusie kan men immers niet spreken van een uitgifte van aandelen. De aandeelhouders van de verdwijnende vennootschap worden van rechtswege aandeelhouder in de verkrijgende vennootschap. Vgl. P.J. Dortmond, NV 65 (1987), p. 51; TK 21155 , nr. 3, p. 3; Handboek (1992), nr. 179, p. 270; aldaar wordt ook opgemerkt dat in geval van omwisseling van een aandeel aan toonder in een aandeel op naam men eveneens niet van uitgifte kan spreken. Voor deze omwisseling geldt dus ook niet het vereiste van de notariële akte. 
De notariële akte dient een aantal gegevens te vermelden. Genoemd worden de titel van de rechtshandeling en de wijze waarop het aandeel of het beperkt recht daarop, door de overdragende partij, is verkregen, de persoonlijke gegevens en het adres van de bij de rechtshandeling betrokken personen, de rechtsvorm, naam, adres, en woonplaats van de rechtspersonen die bij de rechtshandeling betrokken zijn, het aantal en het soort aandelen waarop de rechtshandeling betrekking heeft en de naam, woonplaats en adres van de vennootschap op welker aandelen de rechtshandeling betrekking heeft. ${ }^{91}$

Volgens art. 86a/196a BW werkt de levering van een aandeel op naam of de levering van een pandrecht daarop, mits deze heeft plaatsgevonden bij notariële akte, van rechtswege tegenover de vennootschap. ${ }^{92}$ De eigendom gaat op het moment waarop de akte wordt ondertekend over van verkoper naar koper. De levering werkt zelfs ten opzichte van de vennootschap in het geval zij geen weet heeft van de levering. Door deze bepaling wordt in principe een einde gemaakt aan de relatieve werking van de overdracht. De overdracht is dus niet eerst geldig indien de vennootschap de overdracht van de aandelen heeft erkend, danwel de akte van levering aan haar is betekend. Heeft de levering plaatsgevonden conform de eisen van art. 86/196 BW e.v., dan geldt die levering van rechtswege tegenover de vennootschap. Toch zijn wij niet verlost van de termen "'erkenning, betekening en overlegging'. Sterker nog, in een bepaald geval worden zelfs de oude formaliteiten voor het daadwerkelijk verkrijgen van rechten in de vennootschap in ere hersteld. In de tweede zin van art. 86a/196a BW wordt bepaald dat de aan het aandeel verbonden rechten eerst kunnen worden uitgeoefend nadat de vennootschap de rechtshandeling heeft erkend of de akte aan haar is betekend, danwel de rechtshandeling heeft erkend door inschrijving ervan in het aandeelhoudersregister. Deze regel lijdt uitzondering indien de vennootschap zelf partij was bij de rechtshandeling. ${ }^{93}$

Zie hier de wedergeboorte van de relatieve werking in de regeling van de levering van aandelen op naam. Het verschil met de oude situatie is dat nu geen

91 Zie art. 86/196 BW. Zie ook Handboek (1992), nr. 179, p. 269-270; het ontbreken van een of meerdere gegevens doet de levering niet ongeldig zijn, mits voldoende vaststaat wie partij bij de levering van de aandelen zijn en op welke aandelen de levering betrekking heeft. Mutatis mutandis geldt hetzelfde voor de gegevens die worden vermeld in de vestigingsakte van pand.

92 Vanzelfsprekend dient niet alleen voldaan te zijn aan de overige vereisten van art. 3:84 BW, maar ook aan de blokkeringsbepalingen in de stanten.

93 Met partij zijn bij de rechtshandeling wordt bedoeld dat de vennootschap zelf aandelen koopt of verkoopt, dat een beperkt recht op haar eigen aandelen in de vennootschap wordt gevestigd of dat zij een beperkt recht krijgt op een aandeel in de vennootschap, aldus TK 21 155, nr. 3, p. 5. 
sprake is van relativiteit met betrekking tot de geldigheid van de overdracht, maar relativiteit ten aanzien van de rechtsgevolgen van de overdracht. ${ }^{\text {gh }}$

De erkenning van de rechtshandeling kan op een tweetal manieren plaatsvinden. Enerzijds kan erkenning geschieden door een - op erkenning gerichte - verklaring van de vennootschap op te nemen in de akte van levering, danwel op grond van overlegging van een notarieel afschrift of uittreksel van de akte. In dit laatste geval wordt een gedagtekende verklaring (gericht op erkenning door de vennootschap van de leveringshandeling) geplaatst op het overgelegde stuk. ${ }^{95}$ De rechtshandeling kan ook 'eigener beweging' door de vennootschap worden erkend. Deze individuele wijze van erkenning is slechts mogelijk indien de vennootschap weet heeft van een rechtshandeling leidend tot levering van aandelen (danwel vestiging van een pandrecht daarop) en haar geen erkenning daarvan is verzocht, noch een betekening van de akte aan haar heeft plaatsgevonden. Erkenning vindt alsdan plaats door inschrijving van de verkrijger van het aandeel of een beperkt recht daarop in het aandeelhoudersregister. Erkent de vennootschap de rechtshandeling eigener beweging, dan deelt zij dit, per aangetekende brief, mede aan de bij de rechtshandeling betrokken partijen. Hierbij verzoekt zij de partijen alsnog een afschrift of uittreksel van de notariële akte aan haar te overleggen. Indien de vennootschap de stukken heeft ontvangen plaatst zij, als bewijs van de erkenning, een gedagtekende verklaring op het overgelegde stuk. Als datum van de erkenning wordt de dag van inschrijving in het aandeelhoudersregister aangehouden.

Anderzijds kan erkenning van de leverings(vestigings)handeling plaatsvinden door middel van betekening van de akte aan de vennootschap. Het derde lid van art. 86b BW geeft aan wat moet worden betekend. Betekend moet worden een notarieel afschrift of uittreksel van de akte. ${ }^{96}$

Heeft de levering van een aandeel op naam - danwel een beperkt recht daarop plaatsgevonden zonder dat dit heeft geleid tot een inschrijving daarvan in en/of wijziging van het aandeelhoudersregister, dan kan die levering/vestiging niet worden tegengeworpen aan de vennootschap die te goeder trouw is of aan anderen die, te goeder trouw, de in het aandeelhoudersregister ingeschreven

94 Zie G.M. ter Huume, TVVS 1991, p. 314; schrijfster noemt dit relativiteit in vennootschappelijk verband. Het heeft tot gevolg dat de uitoefening van de aandeelhoudersrechten wordt opgeschort tot het moment waarop de vennootschap van de aandelenoverdracht in kennis wordt gesteld. Ter Huume stelt deze vorm van relativiteit tegenover, wat zij noemt, relativiteit van de overdracht. Zie ook G.M. ter Huurne, diss. p. 162-183.

95 Leden 1 en 2 van art. $86 \mathrm{~b} / 196 \mathrm{~b}$ BW.

96 Lid 3 van art. $86 \mathrm{~b} / 196 \mathrm{~b}$ BW. De betekening geschiedt bij deurwaardersexploot. In het Handboek (1992), nr. 179 wordt onder verwijzing naar art. 3:94 lid 1 BW bepaald dat de betekening kan geschieden ten verzoeke van de vervreemder of van de verkrijger. Gezien het bepaalde in art. $86 \mathrm{a} / 196 \mathrm{a}$ lid $2 \mathrm{BW}$ lijkt mij dit goed verdedigbaar. 
persoon als aandeelhouder of eigenaar van een beperkt recht op een aandeel hebben beschouwd. ${ }^{97}$

Art. 86c BW geeft een regeling voor de levering van een aandeel op naam of de levering (vestiging) van een beperkt recht daarop in een vennootschap waarvan de aandelen of certificaten ter beurze noteren, of waarvan aandelen of certificaten van aandelen, naar ten tijde van de rechtshandeling op goede gronden kan worden verwacht, daartoe spoedig zullen worden toegelaten. In dat geval gelden de volgende bepalingen. Levering van aandelen op naam in een dergelijke vennootschap, alsmede de vestiging van een beperkt recht daarop, geschiedt door middel van een daartoe bestemde akte. ${ }^{98}$ Is de vennootschap niet zelf partij bij die rechtshandeling dan dient de levering schriftelijk door de vennootschap te worden erkend. Deze erkenning vindt plaats door in de akte van levering een daartoe strekkende verklaring op te nemen, danwel door een gedagtekende verklaring houdende de erkenning op de akte of op een notarieel, door de vervreemder gewaarmerkt, afschrift of uittreksel daarvan te doen plaatsen. Betekening van de akte of het afschrift of uittreksel aan de vennootschap staat gelijk met erkenning door de vennootschap. In afwijking van het vorenstaande kunnen de statuten bepalen dat, indien er voor het aandeel een aandeelbewijs is afgegeven, voor de levering afgifte van het aandeelbewijs aan de vennootschap verplicht is. ${ }^{99}$

Is het aandeelbewijs aan de vennootschap afgegeven dan kan de vennootschap de levering erkennen door op het aandeelbewijs een aantekening te plaatsten waaruit van de erkenning blijkt of door het afgegeven bewijs te vervangen door een nieuw aandeelbewijs luidende ten name van de verkrijger.

In het vierde lid van art. 86c BW wordt een tweede mogelijkheid geboden met betrekking tot de vestiging van een pandrecht op een aandeel op naam in een naamloze vennootschap, namelijk de vestiging van een stil pandrecht. Het pandrecht wordt in dit geval gevestigd zonder erkenning door of betekening aan de vennootschap. Art. 3:239 $\mathrm{BW}$ is hierop van overeenkomstige toepassing.

97 Zie G.M. ter Huume, diss. p. 179-183. Zie ook § I.5.2.2.

98 Voor levering alsmede uitgifte (na oprichting) van aandelen als bedoelt in art. $86 \mathrm{c}$ wordt de eis van de notariële akte niet gesteld. Zie $M$. van Olffen, D.F.M.M. Zaman, Nieuwe bepalingen omtrent uitgifte en levering van aandelen op naam, Preadvies 1994, p. 19. Zie ook G.M. ter Huurne, diss. p. 207; schrijfster stelt ten aanzien van de ratio van deze bepaling, die afwijkt van de regeling van de 'gewone' nv: "Er gelden geen vormvoorschriften voor de uitgifte van aandelen op naam door een reeds opgerichte beursvennootschap. De wetgever streeft niet naar de registratie door de overheid van aandeelhouders in zo'n vennootschap. De voor de 'gewone' nv vereiste notariële akte van uitgifte behoefde daarom niet te worden voorgeschreven. Uit vrees voor administratieve rompslomp en kosten is ook afgezien van het verplicht stellen van een onderhandse akte van uitgifte."

99 Dit vereiste geldt niet indien het aandeelbewijs is verloren, ontvreemd of vemietigd en niet volgens de statuten kan worden ontvangen. 
waarbij erkenning door of betekening aan de vennootschap in de plaats treedt van de in het derde lid van artikel 3:239 bedoelde mededeling. Het systeem is dan als volgt. Een pandrecht op een, tegen een of meer bepaalde personen (lees; de rechtspersoon), uit te oefenen recht op naam (lees: aandeel op naam) kan worden gevestigd bij authentieke of geregistreerde onderhandse akte, zonder mededeling daarvan aan die personen (lees: de rechtspersoon), mits dat recht op het tijdstip van vestiging van het pandrecht reeds bestaat of rechtstreeks zal worden verkregen uit een dan reeds bestaande rechtsverhouding.

Schiet de pandgever in zijn verplichtingen jegens de pandhouder tekort of geeft hij hem goede grond te vrezen dat in die verplichtingen zal worden tekortgeschoten, dan is de pandhouder bevoegd van de verpanding mededeling te doen aan de rechtspersoon. Aan deze mededeling wordt gestalte gegeven door betekening van de vestigingsakte van het pandrecht aan de rechtspersoon, danwel door middel van erkenning van de vestiging door de vennootschap. Het stil pandrecht verandert dan in een openbaar pandrecht.

Indien een pandrecht op deze wijze wordt gevestigd kan de pandhouder eerst gebruik maken van de hem toekomende rechten, nadat afgifte van hetzij de vestigingsakte van het pandrecht, hetzij een notarieel of gewaarmerkt afschrift c.q. uittreksel daarvan en afgifte van het aandeelbewijs, indien deze door de vennootschap zijn uitgegeven, aan de vennootschap heeft plaatsgevonden. ${ }^{100}$

Met de invoering van de wet van 3 september 1992, houdende wijziging van de regeling van de overdracht van aandelen op naam in naamloze vennootschappen en besloten vennootschappen, werd ook art. $85 \mathrm{BW}$ gewijzigd. ${ }^{101}$ Het bestuur van de naamloze vennootschap is gehouden, in het aandeelhoudersregister, de namen en de adressen van de pandhouders op te nemen onder vermelding van de hen, overeenkomstig de leden 2 en 4 van art. $89 \mathrm{BW}$, toekomende rechten.

Voor de wijze van vestiging van een pandrecht op een aandeel in een besloten vennootschap zij verwezen naar de beschrijving van de vestiging van pandrecht op aandelen op naam in een naamloze vennootschap. ${ }^{102}$ Hetgeen aldaar is opgemerkt betreffende aandeelbewijzen vindt natuurlijk geen toepassing bij de besloten vennootschap. Immers, uitgifte van bewijzen van aandeelhouderschap is bij de besloten vennootschap niet toegestaan (art. 175 lid 2 BW).

100 Art. 89 lid $6 \mathrm{BW}$.

101 Art. 85 BW werd eerder veranderd bij de Wet vruchtgebruik en pandrecht op aandelen, TK 12 897, no. 1 en 2, art. 2.3.2.7. (art. 85).

102 Voor de levering van aandelen op naam in een BV dan wel de vestiging van een pandrecht daarop wordt verwezen naar de artt. 196, 196a en 196b BW. Deze regeling komt overeen met de regeling van levering en verpanding van op naam gestelde aandelen bij een naamloze vennootschap. 


\title{
I.5.2 De nieuwe regeling nader bezien
}

Na te zijn ingegaan op de inhoud van de nieuwe regeling voor levering van aandelen op naam in besloten en naamloze vennootschappen, en daarmee dus ook op de gewijzigde methode van verpanding van aandelen op naam, zal ik nu enkele aspecten van deze nieuwe regeling, in relatie tot het verpanden van aandelen, nader bezien en deze aan een kritische beschouwing onderwerpen.

\section{I.5.2.1 Stil pandrecht op aandelen op naam in een BV of in een gewone - niet beursgenoteerde - NV?}

Wanneer we de huidige regeling inzake de vestiging van een stil pandrecht op aandelen op naam bezien, dan komen we tot de volgende bevindingen.

Het enige artikel waarin gerept wordt over de mogelijkheid van het vestigen van een stil pandrecht op aandelen op naam is art. $86 \mathrm{c} \mathrm{BW}$. In lid 4 van die bepaling lezen we het volgende:

\begin{abstract}
"Een pandrecht kan ook worden gevestigd zonder erkenning door of betekening aan de vennootschap. Alsdan is artikel 239 van Boek 3 van overeenkomstige toepassing, waarbij erkenning door of betekening aan de vennootschap in de plaats treedt van de in lid 3 van dat artikel bedoelde mededeling."
\end{abstract}

Het wettelijk systeem is dus, dat op aandelen op naam in een vennootschap, waarvan aandelen of certificaten van aandelen zijn toegelaten tot de officiële notering van een effectenbeurs of waarvan aandelen of certificaten van aandelen spoedig tot de notering aan die beurs worden toegelaten, een stil pandrecht kan worden gevestigd. Een bepaling met deze strekking ontbreekt in de wettelijke regeling van de gewone (besloten) naamloze vennootschap en de besloten vennootschap. In de MvT op (het voorgestelde) art. 86c BW lezen wij:

\footnotetext{
"De leden 4 en 5 (van het voorgestelde artikel $86 c ; J H$ ) stemmen overeen met de leden 5 en 6 van artikel 86 van de derde misbruikwet (welk artikel nimmer in werking is getreden; $J H$ ). Omdat de bepalingen alleen van toepassing kunnen zijn op beursvennootschappen, daar zij samenhangen met de complicaties die zich voordoen bij notering van aandelen van Nederlandse vennootschappen op Amerikaanse beurzen, zijn deze leden - in afwijking van de derde misbruikwet en de huidige wet - alleen opgenomen in artikel 86c. ${ }^{\text {"103 }}$
}

De vraag dringt zich op of op aandelen op naam in een niet beursgenoteerde naamloze vennootschap of in een besloten vennootschap een stil pandrecht kan

103 TK 21 155, nr. 3, p. 8. 
worden gevestigd. Gaan we bij de beantwoording van deze vraag uit van de tekst van de wet dan komen wij, in beginsel, tot een negatief antwoord. ${ }^{104}$

Ook al lijkt de wet te dwingen tot dit negatieve antwoord ben ik toch van mening dat een stil pandrecht - onder omstandigheden - gevestigd moet kunnen worden op aandelen op naam in een gewone naamloze vennootschap of besloten vennootschap. Ik zie namelijk geen goede grond partijen deze optie in het algemeen te ontnemen. Voorstelbaar is namelijk het geval waarin een aandeelhouder zijn aandelen in pand wil geven aan een kredietverschaffer, zonder dat hij dit ter ore van de vennootschap wil laten komen. Het ontbreken van een wettelijke bepaling waarin de vestiging van een stil pand op aandelen in een niet beursgenoteerde naamloze vennootschap of een besloten vennootschap uitdrukkelijk wordt toegestaan, staat er immers niet aan in de weg dat zo een vestiging in de praktijk kan worden gerealiseerd. Een stil pandrecht kan alsdan ontstaan door de betekening van de pandakte aan de vennootschap achterwege te laten, danwel er voor te zorgen dat de vennootschap de rechtshandeling waarbij de aandelen worden verpand niet kan erkennen. ${ }^{105}$ Ik zou dan ook met kracht willen verdedigen dat de vestiging van een stil pandrecht ook bij niet beursgenoteerde naamloze vennootschappen en besloten vennootschappen mogelijk is.

Ter nadere onderbouwing van mijn stellingname is het wellicht zinvol enige aandacht te besteden aan de aard van het aandeel en vervolgens een kort uitstapje te maken naar het algemene vermogensrecht. Laten we de lex specialis even terzijde leggen en laten we onze aandacht vestigen op de lex generalis betrekkelijk de verpanding van rechten op naam. Een aandeel is een recht, het is geen vorderingsrecht, het is wel een vermogensrecht. Tenzij de lex specialis van Boek $2 \mathrm{BW}$ hieraan derogeert, zijn de bepalingen van het vermogensrecht ook op aandelen van toepassing. Zoals wij reeds zagen bevat de lex specialis van Boek 2 BW geen bepaling betrekkelijk de vestiging van een stil pandrecht op naamaandelen in besloten vennootschappen of niet beursgenoteerde naamloze vennootschappen. Wel staat de wetgever toe dat op aandelen op naam in een beursnoterende vennootschap een stil pandrecht gevestigd wordt. Indien zo een stil pandrecht gevestigd wordt, wordt art. 3:239 BW van overeenkomstige toepassing verklaard. Naar mijn mening kan met behulp van dit artikel worden verdedigd dat ook op een op naam gesteld aandeel in een besloten vennootschap of in een gewone

$104 \mathrm{Vgl} . M$. van Olffen, Uitgifte en overdracht van aandelen op naam, amendementen aanvaard, JBN 1992, p. 7.

$105 \mathrm{Zie}$ in gelijke zin G.M. ter Huurne, diss. p. 206. Schrijfster merkt in dit kader op dat door het registreren van de notariële vestigingsakte van het pandrecht de overheid steeds op de hoogte is van het bestaan van het stille pandrecht en de daarbij betrokken personen. Zie ook $M$. van Olffen, D.F.M.M. Zaman, Nieuwe bepalingen omtrent uitgifte en levering van aandelen op naam, Preadvies 1994, p. 54. 
naamloze vennootschap een stil pandrecht kan worden gevestigd. Indien we het eerste lid van het genoemde artikel plaatsen tegen de achtergrond van het vennootschapsrecht dan lezen we het volgende:

"Pandrecht op een aandeel op naam, (...) kan ook worden gevestigd bij authentieke of geregistreerde onderhandse akte, zonder mededeling daarvan aan de vennootschap. (...)."

Mijns inziens staat geen lex specialis er aan in de weg de vestiging van een stil pandrecht op aandelen op naam in een besloten vennootschap of een niet beursgenoteerde naamloze vennootschap mogelijk te doen zijn.

Echter, deze stellingname verdient enige nuancering. Wanneer de statuten van de vennootschap verpanding van aandelen op naam toestaan dan kunnen de aandelen naar mijn mening ook stil worden verpand. Tot een andere conclusie kom ik in het geval waarin de statuten van een niet beursgenoteerde naamloze vennootschap of een besloten vennootschap de mogelijkheid van verpanding van aandelen geheel uitsluiten. Onder deze omstandigheden lijkt mij de vestiging van een stil pandrecht rechtens niet geldig. Hoe stil het pandrecht ook is, het blijft een pandrecht. Dit geld mijns inziens eveneens voor de stille verpanding van aandelen op naam in een beursfonds wanneer de mogelijkheid tot vestiging van een pandrecht statutair is uitgesloten. Tot dezelfde slotsom kom ik indien de statuten van een - al dan niet - beursgenoteerde naamloze vennootschap of een besloten vennootschap een kwaliteitseis bevatten welke bepaalt dat de aandeelhouder die zijn aandelen verpandt, deze terstond, conform de blokkeringsbepalingen, dient over te dragen. De vennootschap heeft door het opnemen van een dergelijke statutaire bepaling willen voorkomen dat aandeelhouders hun aandelen aan derden verpanden. Wanneer een aandeelhouder over zou gaan tot de vestiging van een stil pandrecht op zijn pakket dan komt dit weliswaar niet meteen ter ore van de vennootschap, duidelijk is wel dat de aandeelhouder door het in pand geven van zijn aandelen handelt in strijd met de statutaire bepaling en de ratio ervan.

Tegenstanders van de idee dat, onder omstandigheden, in die gevallen dus waarin de statuten van de vennootschap niet verbieden c.q. toestaan dat een openbaar pand kan worden gevestigd op aandelen die op naam zijn gesteld, ook een stil pandrecht kan worden gevestigd op aandelen op naam in een niet beursgenoteerde naamloze vennootschap en een besloten vennootschap, zouden kunnen aanvoeren dat een besloten vennootschap danwel een gewone naamloze vennootschap, die aandelen op naam heeft uitgegeven, wordt geconfronteerd met 'vreemde eenden in de bijt' die bepaalde rechten jegens de vennootschap kunnen uitoefenen, hetgeen niet past bij de ratio van de beslotenheid van de vennootschap. Tegen dit 
bezwaar zou ik willen anvoeren, dat in dit geval art. 89 lid $6 \mathrm{BW}^{106}$ analoog dient te worden toegepast en wel in die zin dat zolang er geen erkenning door of betekening van de vestiging van het pandrecht aan de vennootschap heeft plaatsgevonden, de in art. $89 \mathrm{BW}$ vermelde rechten niet door de pandhouder kunnen worden uitgeoefend. De besloten vennootschap of de (besloten) naamloze vennootschap zal op die manier niet geconfronteerd kunnen worden met derden die enige rechten jegens haar kunnen doen gelden.

Men zou kunnen aanvoeren dat het besloten samenwerkingsverband wel onder spanning komt te staan indien de pandhouder overgaat tot executie van het pand wegens het niet nakomen van de verplichtingen zijdens de pandgever.

Naar mijn mening speelt dit probleem - in beginsel - geen echte rol van betekenis. In de eerste plaats zal de executie immers dienen te geschieden conform de blokkeringsbepaling. ${ }^{107}$ Voor de besloten vennootschap is deze wettelijk voorgeschreven en de statuten van een besloten naamloze vennootschap zullen zeker een blokkeringsregeling bevatten. ${ }^{108}$ In de tweede plaats zal de houder van een stil pandrecht op de aandelen niet zonder meer tot executie van de in pand gegeven aandelen kunnen overgaan. Executie van het pand kan pas plaatsvinden nadat de schuldenaar/pandgever in verzuim is. ${ }^{109}$ Op het moment dat de pandgever in zijn verplichtingen jegens de pandhouder tekortschiet, danwel in die verplichtingen dreigt tekort te schieten, is de pandhouder bevoegd van de verpanding mededeling te doen aan de vennootschap, aldus art. 3:239 lid 3 BW. Deze mededeling zal in de praktijk geschieden doordat de pandhouder de pandakte aan de vennootschap betekent danwel de pandakte door de vennootschap laat erkennen. Eerst na die 'mededeling' zal de pandhouder kunnen gaan executeren. Immers, wanneer A een vordering heeft op B en A deze vordering stil verpandt aan $C$, voor een schuld die $A$ aan $C$ heeft, dan zal $C$ eerst onder $B$ kunnen gaan executeren op het moment waarop $A$ in verzuim is en B op de hoogte wordt gebracht van het feit dat $\mathrm{A}$ zijn vordering op $\mathrm{B}$ aan $\mathrm{C}$ heeft verpand. Ik zie geen goede grond tot een andere conclusie te komen wanneer het niet gaat om de

106 Met de inwerkingtreding van de wet van 3 september 1992 is ook art. 89 aangepast. Aan dit artikel is een zesde lid toegevoegd, hetgeen bepaald dat: "Is bet pandrecht overeenkomstig art. $86 \mathrm{c}$ lid 4 gevestigd, dan komen de rechten volgens dit artikel de pandhouder eerst toe nadat het pandrecht door de vennootschap is erkend of aan haar is betekend."

107 "Een blokkeringsregeling bindt ook de pandhouder. Verkoop door de pandhouder zal met inachtneming van de blokkeringsregeling moeten geschieden." Aldus Handboek (1992), nr. 184.

108 De pandexecutie heeft mijns inziens slechts dan gevolgen voor de beslotenheid van de vennootschap indien een dermate groot pakket wordt geëxecuteerd, dat de overige aandeelhouders niet in staat zijn dit pakket over te nemen. Voor de beantwoording van de interessante vraag of de houder van een stil pandrecht stemrecht verkrijgt op het moment waarop het stille pand door erkenning of betekening wordt omgezet in een gewoon pandrecht, volsta ik op deze plaats met een verwijzing naar $\$ 11.7$.

109 Zie ant. 3:248 BW. 
executie van een stil pandrecht op een vordering maar om een stil pandrecht op een aandeel op naam. ${ }^{10}$

Aan het einde van deze paragraaf past een opmerking ten aanzien van de eis die aan de pandakte wordt gesteld. Dient het stille pandrecht op aandelen op naam te worden gevestigd bij - authentieke - notariële akte of volstaat een geregistreerde onderhandse akte van verpanding. Bezien wij de wet dan blijkt uit art. 3:239 BW dat een stil pandrecht op een recht op naam kan worden gevestigd bij authentieke of geregistreerde onderhandse akte. Partijen kunnen dus volstaan met een tussen hen opgemaakte akte die ter registratie wordt aangeboden. Ik zou willen verdedigen dat een stil pandrecht op een aandeel op naam, in het kader van de rechtszekerheid en de rechtsgelijkheid, gelijk de vestiging van een openbaar pandrecht op aandelen op naam, dient te worden gevestigd bij notariële akte. Als argument zou ik hiervoor willen aanvoeren dat, wanneer een stil pandrecht, gevestigd bij geregistreerde onderhandse akte, door betekening aan danwel erkenning door de vennootschap openbaar wordt, een ongelijkheid ontstaat ten aanzien van het van meet af aan gevestigde openbare pandrecht. Indien men, met mij, van mening is dat vestiging van een stil pandrecht als hier aan de orde, tot de mogelijkheden behoort, lijkt, met het oog op de vereisten betrekkelijk de vestiging van een openbaar pand op deze aandelen, het eisen van een notariële akte ook voor rechtsgeldige vestiging van een stil pandrecht, voor de hand te liggen.

\title{
I.5.2.2 Openbaar en stil pandrecht op aandelen op naam; goede trouw en be- scherming
}

\begin{abstract}
"Indien een rechtshandeling als bedoeld in het eerste lid heeft plaatsgevonden zonder dat dit heeft geleid tot een daarop aansluitende wijziging in het register van aandeelhouders, kan deze noch aan de vennootschap noch aan anderen die te goeder trouw de in het aandeelhoudersregister ingeschreven personen als aandeelhouder of eigenaar van een beperkt recht op een aandeel hebben beschouwd, worden tegengeworpen."
\end{abstract}

Aldus art. 86a lid 3 BW (voor de besloten vennootschap is een gelijkluidende bepaling opgenomen in art. 196a lid $3 \mathrm{BW}$ ).

De strekking van deze bepaling is dat wanneer een verpanding van aandelen bij notariële akte heeft plaatsgevonden en deze verpanding vervolgens niet is aangetekend in het aandeelhoudersregister, de vennootschap en anderen te goeder trouw worden beschermd, indien zij de in het aandeelhoudersregister ingeschreven persoon als (beperkt) gerechtigde op het aandeel hebben beschouwd. ${ }^{11}$ Het

110 Zie omtrent stil pandrecht op vorderingen op naam, H.J. Snijders, E.B. Rank-Berenschot, Goederenrecht 1994, nr. 543.

111 Zie voor de strekking van en kritiek op deze bepaling ten aanzien van de levering van aandelen op naam, G.M. ter Huume, diss. p. 179 e.v. 
artikellid ziet op de situatie waarin geen aantekening van verpanding in het aandeelhoudersregister beeft plaatsgevonden. Onder welke omstandigheden zou zich het geval waarop art. 86a/196a lid 3 BW ziet kunnen voordoen en welke gevolgen zouden hieraan verbonden kunnen worden?

Als ik goed zie kan een drietal posities worden onderscheiden. In het eerste geval vestigt de aandeelhouder/pandgever een pandrecht op zijn aandelen ten behoeve van een derde (de pandhouder). De vestiging van het pandrecht geschiedt bij notariële akte. De partijen laten de akte van verpanding aan de vennootschap betekenen, danwel dragen er zorg voor dat de vennootschap de pandakte kan erkennen. Vervolgens maakt de vennootschap aantekening van de vestiging van het beperkte recht op de aandelen in het aandeelhoudersregister. De vennootschap vermeldt hierbij de datum waarop de pandhouder het pandrecht verkregen heeft en welke rechten aan de pandhouder toekomen. ${ }^{112}$ Hier speelt de problematiek van art. 86a/196a lid $3 \mathrm{BW}$ geen rol. De vestiging van het pandrecht is immers bekend bij de vennootschap en derden. ${ }^{113}$ De vennootschap en derden kunnen alsdan geen beroep doen op de regeling van art. 86a/196a lid $3 \mathrm{BW}$.

In het tweede geval wordt het pandrecht rechtsgeldig gevestigd, de akte van verpanding wordt aan de vennootschap betekend, danwel de vennootschap erkent de vestiging van het pandrecht maar er vindt geen aantekening in het aandeelhoudersregister plaats. De vennootschap is in deze situatie op de hoogte van het gevestigde pandrecht. $\mathrm{Zij}$ kan zich mijns inziens niet beroepen op het bepaalde in art. 86a/196a lid $3 \mathrm{BW}$. Immers, door het feit dat de pandakte aan haar is betekend (door haar is erkend) droeg zij kennis van de vestiging van het pandrecht en kan zij zich niet te goeder trouw beroepen op het feit dat geen aantekening van de vestiging in het register heeft plaatsgevonden. Het bijhouden c.q. wijzigen van het aandeelhoudersregister is immers een taak van - het bestuur van - de vennootschap. Ten aanzien van de goede trouw van derden ligt dit evenwel anders. Hierop zal ik later in deze paragraaf ingaan.

In het derde geval heeft de aandeelhouder een pandrecht gevestigd op zijn aandelen op naam ten behoeve van de pandhouder. Het pandrecht is gevestigd bij notariële akte maar er heeft geen betekening aan danwel erkenning door de vennootschap plaatsgevonden. De vennootschap heeft de vestiging van het pandrecht ook niet eigener beweging erkend. De vennootschap is dus niet op de

112 Zie art. 85/194 lid 1 jo 89/198 BW.

113 Hoe kunnen derden wetenschap verkrijgen over het al dan niet gevestigd zijn van een beperkt recht op aandelen in een besloten venoootschap? Het aandeelhoudersregister is immers niet openbaar, niet-aandeelhouders hebben geen recht op inzage in het aandeelhoudersregister vanaf het moment dat de aandelen zijn volgestort (art. 85/194 lid 4 BW). Naar mijn mening laat zich dit probleem in de praktijk eenvoudig oplossen doordat de potentiēle pandhouder, alvorens hij een krediet verstrekt aan de aandeelhouder/pandgever, de aandeelhouder verzoekt een afschrift van het aandeelhoudersregister aan hem te overleggen. Komt dit afschrift er niet dan zal de beoogde pandhouder geen krediet verschaffen. 
hoogte van het gevestigde pandrecht. Het pandrecht heeft dus een stil karakter. ${ }^{114}$ Hoe nu in dit geval te oordelen over de gevolgen van de goede trouw van art. 86a/196a lid 3 BW? Eerst de goede trouw van de vennootschap. Indien de vennootschap noch partij is geweest bij de vestiging van het pandrecht, noch betekening van de akte van verpanding aan c.q. erkenning door haar heeft plaatsgevonden, kan moeilijk worden aangenomen dat de vennootschap op de hoogte is van de verpanding van aandelen in haar kapitaal. ${ }^{115}$ Het niet wijzigen van het aandeelhoudersregister kan haar niet worden aangerekend. $\mathrm{Zij}$ is te goeder trouw. Heeft dit nu gevolgen voor de positie van de houder van het stille pandrecht? Ik zou denken van niet. Immers, tot het moment waarop het pandrecht zijn stille karakter verliest, dus door betekening van de pandakte danwel door erkenning daarvan, is de pandhouder niet gerechtigd de aan het aandeel verbonden rechten uit te oefenen. In relatie tot de houder van het stille pandrecht kan de vennootschap dus weinig kwaad doen. ${ }^{116}$ Hoe is echter de situatie betrekkelijk de goede trouw van de 'anderen'?

Zoals reeds eerder werd opgemerkt hebben 'anderen' geen rechtstreekse toegang tot het aandeelhoudersregister van de vennootschap. Zij kunnen er - in beginsel niet achterkomen of op bepaalde aandelen een beperkt recht rust. Men stelle zich het volgende geval voor.

A, houder van een pakket aandelen in een besloten vennootschap $X$, heeft op zijn aandelen een stil pandrecht gevestigd ten behoeve van Bank Y. $\mathrm{Na}$ verloop van enige tijd vestigt $A$ een tweede stil pandrecht op dezelfde aandelen ten behoeve van Bank $Z$. Nog enige tijd later vestigt $A$ een recht van pand op zijn aandelen ten behoeve van $C$, waarbij de pandakte aan de vennootschap wordt betekend en de vennootschap van deze verpanding een aantekening maakt in het aandeelhoudersregister. Bij de vestiging van het tweede stille pandrecht en het openbare pandrecht gaat de pandgever voorbij aan de op hem rustende verplichting van art. 3:237

114 Ik ga er in dit geval vanuit dat de statuten van de vennootschap de verpanding van aandelen toestaan.

115 Tot een andere conclusie vermag men te komen wanneer de groot aandeelhouder/bestuurder van een vennootschap zijn aandelen in pand geeft aan een bank, zonder dat de pandakte aan de vennootschap wordt betekend of de vestigingshandeling door haar wordt erkend. In zo'n geval kan men moeilijk volhouden dat de vennootschap niet op de hoogte is. Verdedigbaar zou m.i. zijn dat de vennootschap dan over moet gaan tot erkenning eigener beweging. Voorts ben ik van mening dat de vennootschap, wanneer zij op de hoogte raakt van het gevestigde stille pandrecht, het pandrecht eigener beweging kan erkennen door aantekening van de vestiging te maken in het aandeelhoudersregister. Dit volgt m.i. uit de strekking van het bepaalde in art. $86 \mathrm{c} \mathrm{lid} 4$ jo $86 \mathrm{a}$, leden 1 en 2 BW. Het karakter van het pandrecht verandert dan van stil in openbaar.

116 Zie art. 86a/196a BW, tweede volzin; zie ook Handboek (1992), nr. 184: "Bij een stil pandrecht behoudt $0 . i$. de pandgever het recht op dividend (vgl. artt. 3:237 en 3:239)." 
lid 2 BW. ${ }^{117}$ Hoe nu te oordelen over de rechtsposities van de verschillende pandhouders?

Alvorens de rechtsposities van de diverse partijen te bezien dient te worden opgemerkt dat zowel $\mathrm{Y}$ als $\mathrm{Z}$ als $\mathrm{C}$ te goeder trouw zijn. Geen der pandhouders was op de hoogte, kon op de hoogte zijn, van de eerder gevestigde pandrechten. De pandgever heeft immers in beide gevallen verzuimd te verklaren dat er reeds een beperkt recht rustte op de door hem gehouden aandelen.

Wat is nu rechtens ten aanzien van het eerste stille pandrecht, het tweede stil gevestigde pandrecht en het derde openbare pand?

Wanneer we ervan uitgaan dat, zoals ik in de vorige paragraaf reeds verdedigde, op aandelen op naam in besloten vennootschappen en niet-beursgenoteerde naamloze vennootschappen een stil pandrecht gevestigd kan worden, dient men mijns inziens te concluderen dat het eerste stille pandrecht rechtsgeldig is gevestigd. Ten aanzien van de vraag of dit pandrecht bij (authentieke) notariële akte, danwel bij geregistreerde onderhandse akte gevestigd dient te worden, heb ik in de vorige paragraaf aangegeven dat dit naar mijn mening steeds bij notariële akte dient te geschieden. De rechten verbonden aan de verpande aandelen zal de pandhouder eerst na 'mededeling' van het pandrecht aan de vennootschap kunnen uitoefenen.

Ten aanzien van het tweede stille pandrecht het volgende. Het gaat hier dus om een tweede stil pandrecht gevestigd op een recht op naam. Het tweede lid van art. 3:238 BW is niet van toepassing. Het tweede stille pandrecht zal dus nimmer prevaleren boven het eerdere gevestigde stille pandrecht. Zelfs niet wanneer de tweede stil pandhouder te goeder trouw was op het moment van vestiging van het stil pandrecht. ${ }^{118}$

117 Art. 3:237 lid 2 luidt: "De pandgever is verplicht in de akte te verklaren dat hij tot het verpanden van het goed bevoegd is alsmede hetzij dat op het goed geen beperkte rechten rusten, hetzij welke rechten daarop rusten."

118 Asser-Mijnssen, Zakenrecht III, nr. 123. In nr. 124 wordt opgemerkt: "In geval van stil pandrecht op zaken ligt het voor de hand een lager gerangschikte pandhouder een vorm van bescherming te bieden indien hij de zaak in zijn macht krijgt en op dat moment te goeder trouw is. Een dergelijke bescherming is in overeenstemming met het beginsel van art. 3:86. Van dat beginsel is het bepaalde bij art. 3:238, tweede lid een uitvloeisel: rust op de stil verpande zaak een beperkt recht dat de pandhouder op het tijdstip waarop hij de zaak in zijn macht krijgt niet kent of behoort te kennen dan gaat zijn - dan vuistpand - in rang boven dit beperkte recht. Een dergelijke bepaling ontbreekt in geval van stil pandrecht op een recht op naam. Eerdere mededeling van het pandrecht aan degene tegen wie het recht moet worden uitgeoefend, heeft niet tot gevolg dat het meegedeelde pandrecht in rang boven op het recht rustende pandrechten gaat waarvan nog geen mededeling is gedaan." De mededeling van het stille pandrecht - het pandrecht wordt dan openbaar - is wel van belang voor de bevoegdheid tot inning of het door opzegging opeisbaar maken in de zin van art. 3:246 leden 1 en 2 BW. 
Tot dezelfde conclusie komen we ten aanzien van het nog later gevestigde openbare pand. Wanneer de pandgever een pandrecht vestigt op zijn reeds verpande aandeel, dan kan het oudere pandrecht worden tegengeworpen aan de houder van het jongere recht.

Met betrekking tot de levering van aandelen op naam komt Van der Grinten tot een soortgelijke opvatting. Hij schrijft:

\begin{abstract}
"Het gevolg van deze bepaling (art. 2:86a/l96a lid $3 B W ; J H$ ) is voorts, dat indien de gewezen aandeelhouder het overgedragen aandeel aan een ander die de eendere overdracht niet kende of redelijkerwijs kon kennen, overdraagt de eerdere overdracht niet aan die ander kan worden tegengeworpen. Dit voert tot de conclusie dat ten gevolge van de tweede overdracht de eerste overdracht geen effect heeft. Het is o.i. cen zonderling en onbevredigend stelsel. ${ }^{\text {119 }}$
\end{abstract}

Ook Dortmond juicht het gekozen stelsel niet toe. Hij is echter van mening dat lid 3 van art. 86a/196a BW niet de goederenrechtelijke werking heeft die haar door Van der Grinten wordt toebedeeld. Hij acht de werking van het derde lid van genoemd artikel dan ook beperkter. ${ }^{120}$

Dortmonds opvatting deel ik ook met betrekking tot de vestiging van beperkte rechten op aandelen op naam. Deze conclusie is volledig te rijmen met de regels van het gemene goederenrecht betrekkelijk de stille verpanding van vorderingen op naam. Het eerste gevestigde stille pandrecht gaat in rang boven een later gevestigd pandrecht, stil of openbaar. De pandhouder wordt niet beschermd tegen onbevoegdheid van de pandgever, ook niet wanneer het pandrecht wordt medegedeeld aan de schuldenaar en de pandhouder op dat moment te goeder trouw is. De tweede pandhouder zal slechts dan worden beschermd tegen de onbevoegdheid van de pandgever, wanneer die onbevoegdheid voortvloeit uit een gebrek in de titel of de levering die voor de vroegere vestiging was vereist, indien de pandhouder te goeder trouw is (in de zin van art. 3:88 BW) op het moment dat mededeling van de verpanding wordt gedaan. ${ }^{121}$

119 Handboek (1992), nr. 179, p. 271/272.

120 Rechtspersonen, P.J. Dortmond, J.J.M. Brood-Grapperhaus, aantekening 4 bij art. 196a, p. 196a - 4. Dortmond schrijft: "Onzes inziens heeft lid 3 echter niet de goederenrechtelijke werking die Van der Grinten (curs. origineel) daaraan geeft. Uit de wetsgeschiedenis blijkt dat de werking van art. 196a, lid 3, veel beperkter is. Zie MvA I (W.O. 21 155, nr. 211b, blz. 2), waar als voorbeeld van de rechtsonzekerheid, die ant. 196a, lid 3 moet voorkomen, wordt genoemd: 'aan de stemming in de algemene vergadering van aandeelhouders hebben gewezen aandeelhouders deelgenomen; bij de toepassing van een blokkeringsregeling zijn aandeelhouders betrokken die hun aandeel reeds hadden overgedragen; aandeethouders die in het aandeelhoudersregister staan vermeld, worden meegeteld bij de toepassing van de geschillenregeling, de uitkoopregeling of het enquêterecht.' Ook uit de mondelinge behandeling (EK 34-1557 e.v.) blijkt dat het artikellid deze beperktere werking heeft."

121 Asser-Mijnssen, Zakenrecht III, nr. 123. 
Het eerste gevestigde stille pandrecht blijft dus hoogste in rang. Noch door toepassing van art. 86a/196a lid $3 \mathrm{BW}$, noch door mededeling van een later gevestigd stil pandrecht vindt rangwisseling plaats. Overigens dient opmerkt te worden dat een tweede - stil - pandrecht, op dezelfde aandelen, niet erg aantrekkelijk zal zijn. De houder van het oudste pandrecht zal immers zijn hele vordering kunnen verhalen op de in pand gegeven aandelen, met het risico dat voor de latere pandhouders weinig tot niets overblijft.

Voor het geval waarin een lager gerangschikte pandhouder zijn pandrecht uitoefend wordt een voorziening gegeven door de artt. 3:253 BW en 490b Rv. De houder van een jonger pandrecht dient van hetgeen hij, krachtens executie van het pandrecht, heeft ontvangen zoveel aan de hoger gerangschikte pandhouder af te dragen als nodig is om de vordering van deze laatste te voldoen. ${ }^{122}$

\section{I.5.3 Verpanding van aandelen in een depot}

Naast de regeling van verpanding van aandelen in Boek 2 van het Burgerlijk Wetboek kennen we een bijzondere regeling voor verpanding van aandelen in de Wet giraal effectenverkeer. ${ }^{123}$ De Wet maakt een onderscheid tussen verpanding van aandelen die zich in een verzameldepot bevinden (artt. 16-25 WGE) en verpanding van aandelen in een girodepot (artt. 40-44 WGE).

Een pandrecht op een aandeel in een verzameldepot kan worden gevestigd ten behoeven van een aangesloten instelling (art. 21 WGE) danwel ten behoeve van een ander (art. 20 WGE). Wordt een aandeel gevestigd ten behoeve van een aangesloten instelling, dan geschiedt dit bij wijze van een overeenkomst tot vestiging van een pandrecht tussen de pandgever en de instelling. In het geval een pandrecht wordt gevestigd ten behoeve van een ander dan een aangesloten instelling dient de weg van art. 20 WGE te worden bewandeld. De vestiging van het pandrecht geschiedt dan door een bijschrijving ten name van de pandhouder in de administratie van de instelling. Mijns inziens zal aan deze bijschrijving eveneens een overeenkomst tot inpandgeving tussen pandgever en pandhouder ten grondslag moeten liggen.

Bevinden de te verpanden aandelen zich in een girodepot, dan zal verpanding slechts mogelijk zijn indien deze geschiedt ten behoeve van een andere aangesloten instelling. Het pandrecht wordt gevestigd door bijschrijving ten name van de andere instelling van het centraal instituut. Aldus art. 42 WGE.

122 Asser-Mijnssen, Zakenrecht III, nr. 122.

123 Wet van 8 juni 1977, stb. 333, houdende bepalingen betreffende het giraal effectenverkeer. 


\section{I.6 Overgang van stemrecht verbonden aan verpande aandelen}

Twee grootaandeelhouders - A en B - in vennootschap XYZ NV zijn voornemens tezamen een andere vennootschap over te nemen. Voor de financiering van deze onderneming stappen zij naar een bank. Deze bank sluit met A en B afzonderlijk een kredietovereenkomst. De bank verlangt voor de nakoming van de hoofdvordering meerdere zekerheid van haar debiteuren. Daartoe gaan zowel A als B met de bank een overeenkomst tot verpanding van effecten aan. Object van deze overeenkomst zijn de aandelen die de kredietnemers houden in XYZ NV. In deze overeenkomst wordt de volgende bepaling opgenomen:

"(...)

Deze inpandgeving geschiedt tot zekerheid voor de betaling van al hetgeen de bank van A (danwel B), hierna te noemen de pandgever, te vorderen heeft of zal hebben, uit welken hoofde ook en voorts onder de volgende bepalingen:

1. De pandgever verleent de bank onherroepelijk volmacht om de zeggenschaps- en de financiële rechten verbonden aan de aan haar verpande aandelen en vorderingen mede namens de pandgever uit te oefenen, te incasseren en daarvoor kwijting te verlenen.

$(\ldots)^{n}$.

In de praktijk is dit een veel voorkomende bepaling. Veelal wordt bij verpanding van effecten overeengekomen dat het stemrecht aan de pandhouder zal toekomen. De pandhouder kan dan tweeërlei doen. Of hij oefent het stemrecht zelf uit, of hij verstrekt de pandgever een -(on)herroepelijke - volmacht tot uitoefening van de zeggenschapsrechten.

De reden voor het opnemen van een dergelijke clausule wordt mijns inziens ingegeven door een combinatie van factoren. De bank heeft aandelen in onderpand ter zekerheid van de nakoming van een kredietovereenkomst. Deze aandelen vertegenwoordigen een zekere economische waarde. Deze waarde is afhankelijk van de waarde van de vennootschap, in welke de verpande aandelen worden gehouden. Door de uitoefening van het stemrecht verbonden aan die aandelen kan de waarde van de vennootschap en dus van de aandelen - mede - worden beinvloed.

Volgt men deze redenering, dan is het zaak het stemrecht met beleid uit te oefenen. De bank zal trachten de zeggenschapsrechten verbonden aan de verpande aandelen zo te gebruiken dat de waarde van het pand min of meer stabiel blijft. Bepaalt men in de overeenkomst tot verpanding van effecten dat het stemrecht verbonden aan de verpande aandelen aan de bank toekomt en dat de 
aandeelhouder/pandgever krachtens volmacht van de bank zal stemmen, dan kan de bank eveneens controle uitoefenen op het stemgedrag van de pandgever. Neemt men daarentegen in de verpandingsovereenkomst geen bepaling op met het oog op de uitoefening van het stemrecht, dan blijft dit bij de aandeelhouder/pandgever. En dan is het nog maar afwachten of het stemgedrag van de aandeelhouder/pandgever mede ten goede komt aan de kredietgever/pandhouder. ${ }^{124}$

\section{a. De naamloze vennootschap}

De hoofdregel met betrekking tot het stemrecht op verpande aandelen in een naamloze vennootschap luidt:

"De aandeelhouder heeft het stemrecht op de verpande aandelen. ${ }^{\text {I2s }}$

Art. 89 lid 3 BW geeft meteen een uitzondering op deze hoofdregel. Het stemrecht verbonden aan de verpande aandelen kan aan de aandeelhouder worden ontnomen en worden toegekend aan de pandhouder. ${ }^{126}$ De wet stelt voor deze overgang van het stemrecht twee cumulatieve vereisten.

In de eerste plaats dient de overgang van het stemrecht bij de vestiging van het pandrecht, in de akte, te zijn bepaald (tenzij dit anders in de statuten is bepaald ${ }^{127}$ en, in de tweede plaats, dient de pandhouder een persoon te zijn aan wie de aandelen vrij kunnen worden overgedragen. Aandelen zouden vrij aan de pandhouder kunnen worden overgedragen indien zij aan toonder luiden. Ook nietgeblokkeerde aandelen op naam zijn vrijelijk overdraagbaar.

Is de pandhouder een persoon aan wie de aandelen niet vrijelijk kunnen worden overgedragen (geblokkeerde aandelen op naam), dan komt hem het stemrecht uitsluitend toe, indien het statutair mogelijk is gemaakt dat het stemrecht over kan gaan op de pandhouder en dit bij de vestiging van het pandrecht is bepaald en

124 In de praktijk zal het evenwel zo zijn dat de kredietverlener zijn krediememer stevig in de greep heeft. Afwijkend stemgedrag van de pandgever zal dan ook door de pandhouder worden bestraft.

$125 \mathrm{Zie}$ ant. $89 \mathrm{lid} 2 \mathrm{BW}$; zie ook art. 3:247 BW. Heeft de aandeelhouder het stemrecht op de verpande aandelen, dan zal in het algemeen de goede trouw met zich brengen, dat de pandhouder hem niet belemmert in de uitoefening van dit recht; zie Handboek (1992), no. 184. Zie ook $F$. Molenaar, Pandrecht, Mon. Nieuw BW, B12a, $2^{\mathrm{e}}$ druk, 1991, p. 72: "Is aan een verpand goed stemrecht vertonden, dan behoudt de pandgever het stemrecht (...). Artikel 3:247 NBW geeft als hoofdregel, dat het stemrecht verbonden aan een verpand recht, aan de pandgever toekomt. Afwijking van die regel kan voortvloeien uit een anders luidende afspraak tussen partijen of uit de bijzondere regeling in Boek 2 BW gegeven voor de NV en de BV."

126 TK 12897 , no. 3, p. 4/5; het vennootschappelijk belang zal echter doorslaggevend zijn.

127 Anders J.V. Nolet, Vnuchtgebruik en pandrecht op aandelen, WPNR 5352 (1976) p. 367; schrijver merkt op dat indien de overdracht van aandelen aan de pandhouder vrij is, het stemrecht overgaat. 
deze bepaling is goedgekeurd door het vennootschapsorgaan dat bij de statuten is aangewezen om goedkeuring te verlenen tot een voorgenomen overdracht van aandelen. Ontbreekt een zodanige statutaire aanwijzing, dan dient de goedkeuring te worden verleend door de algemene vergadering van aandeelhouders. ${ }^{128}$ Het ligt overigens voor de hand dat de algemene vergadering van aandeelhouders bij uitsluiting van andere organen van de vennootschap dient te beslissen over het verlenen van goedkeuring aan de mogelijke overgang van het stemrecht van de pandgever/aandeelhouder naar de pandhouder. De algemene vergadering zal immers - primair - waken voor een mogelijke frustratie van het besloten karakter van de vennootschap. Indien de beslissing omtrent goedkeuring wordt overgelaten aan een ander vennootschapsorgaan, men denke hierbij bijvoorbeeld aan de raad van commissarissen, dan betekent dit dat de aandeelhouders in beginsel geen controle kunnen uitoefenen op het waarborgen van de beslotenheid.

Daar het pandrecht een accessoir recht ${ }^{129}$ is, is het als zelfstandig object niet voor overdracht vatbaar. Het pandrecht gaat slechts over, indien de vordering tot zekerheid waarvan het pandrecht is gevestigd en waaraan het als accessoir recht

128 Indien de pandhouder een persoon is aan wie de aandelen niet vrijelijk kunnen worden overgedragen en indien het orgaan, dat in zo'n geval haar goedkeuring aan een eventuele stemrechtovergang dient te verlenen, haar goedkeuring niet verleend, blijft het stemrecht bij de aandeelhouder berusten. Kan de aandeelhouder onder deze omstandigheden aan de pandhouder een volmacht geven krachtens welke deze laatste in de algemene vergadering van aandeelhouders een stem kan uitbrengen? Algemeen wordt aangenomen dat een aandeelhouder een volmacht kan verlenen aan de pandhouder, tenzij de statuten anders bepalen (zie art. 117/227 BW). Over de geldigheid van een onherroepelijke volmachtverlening aan de pandhouder of een overeenkomst waarin bepaald wordt dat de aandeelhouder zich verplicht een volmacht te verlenen aan de pandhouder zo vaak deze dit verlangt, verbonden met de bepaling dat de aandeelhouder zelf dan geen stem uitbrengt, lopen de meningen uiteen. Zie W. Westbroek, De nieuwste druk van het Handboek, NV 55 (1977), p. 153: schrijver acht zowel een dergelijke onherroepelijke volmacht als ook de overeenkomst geldig daar immers geen overdracht van stemrecht plaatsvindt. De volmachtverlening werkt immers niet privatief, de volmachtgever/aandeelhouder kan te allen tijde zelf van zijn stemrecht gebruikmaken. Anders J.M.M. Maeijer, De stemovereenkomst van aandeelhouders, in: 'Recht zo die gaat' (P.W. van der Ploeg-bundel), p. 102; B. Wachter, Blokkeringsclausules en stemrecht, in: 'Verzekeringen van Vriendschap' (T.J. Dorhout Meesbundel), p. 237. Het antwoord op de vraag naar de geldigheid van overeenkomsten met buitenstaanders met betrekking tot het aan geblokkeerde aandelen verbonden stemrecht is mede aftankelijk van het type (besloten) vennootschap. Bij een werkelijk besloten (naamloze) vennootschap zal tot ongeldigheid van de overeenkomst moeten worden geconcludeerd, terwijl bij de meer 'open' besloten vennootschap en bij de 'open' naamloze vennootschap een dergelijke stemovereenkomst geldig geacht kan worden. Immers de overdracht van het aandeelhouderschap zal in zo'n vennootschap niet aan een zware blokkering zijn onderworpen. Zie ook C.A. Schwar, diss. p. 65 e.v. In § II.5. zal nader worden ingegaan op de verschillende verschijningsvormen van kapitaalvennootschappen.

129 Asser-Mijnssen Zakenrecht III, nr. 27: "Pandrecht is een afhankelijk (accessoir) recht. Een afhankelijk recht is een recht dat aan een ander recht zodanig is verbonden, dat het niet zonder dat recht kan bestaan (3:7). Er moet een ander recht of een andere rechtsverhouding bestaan waarmee het pandrecht is verbonden." 
is verbonden, van de crediteur op een derde overgaat. Dit kan het geval zijn bij cessie van vorderingen (artt. 3:93, $94 \mathrm{BW}$ ), bij subrogratie in vorderingen (art. 6:150 e.v. BW) en bij overgang onder algemene titel. ${ }^{130}$ Treedt een ander, krachtens een van de bovenstaande gronden, in de rechten van de pandhouder, dan komt hem het stemrecht slechts toe, indien het daartoe aangewezen orgaan, of - bij gebreke daarvan - de algemene vergadering van aandeelhouders, de overgang van het stemrecht goedkeurt (zie ant. 198 lid $3 \mathrm{BW}$ ).

Zoals reeds eerder opgemerkt, worden twee vereisten gesteld aan de overgang van het stemrecht verbonden aan verpande aandelen in een naamloze vennootschap: a) het vereiste van de bepaling van de overgang van het stemrecht in de vestigingsakte van het pandrecht en b) dat van de, theoretische, mogelijkheid ${ }^{131}$ van vrijelijke overdracht van de aandelen aan de pandhouder (in die gevallen waarin statutair is voorzien in een vrije kring). Bezien we wederom de MvT, dan blijkt dat de minister bij verpanding van aandelen, in tegenstelling tot het bepaalde ten aanzien van vruchtgebruik op aandelen, het vennootschappelijk belang doorslaggevend acht. ${ }^{132}$ Gedoeld wordt dan op het waarborgen van het besloten karakter van de naamloze vennootschap. Nemen we nu de twee vereisten opnieuw in ogenschouw, dan lijkt slechts het eerste vereiste effect te sorteren. Immers, beslotenheid speelt bij de naamloze vennootschap, in beginsel, geen rol. Aandelen aan toonder, maar ook niet-geblokkeerde aandelen op naam, in een naamloze vennootschap zijn viij overdraagbaar. De ratio van het vereiste van de vrije overdraagbaarheid van aandelen aan de pandhouder lijkt dus overbodig te zijn.

Een andere redenering geldt voor wat betreft geblokkeerde aandelen op naam in een naamloze vennootschap. ${ }^{133}$ In dit geval is het tweede vereiste van art. 89 lid $3 \mathrm{BW}$ wel degelijk van belang. Immers, hier dient een goedkeuringsregeling, analoog aan die van art. 87 jo $195 \mathrm{BW}$, met betrekking tot de overgang van het stemrecht van aandeelhouder naar pandhouder gevolgd te worden. De beslotenheid van de vennootschap gaat anders op de helling. Een gelijke redenering kan men toepassen in geval van verpanding van preferente beschermingsaandelen. Immers, in geval het stemrecht op preferente beschermingsaandelen niet wordt uitgeoefend door de instantie (stichting) waar de aandelen zijn geplaatst, maar door de pandhouder van de beschermingsprefs (de financier van het kapitaal

130 Art. 3:80 lid 2 BW vermeldt de wijzen van eigendomsverkrijging onder algemene titel: erfopvolging, boedelmeniging en opvolging in het vermogen van een rechtspersoon die beeft opgehouden te bestaan (art. 309 BW).

131 Theoretisch, daar bij een intem besloten naamloze vennootschap de vrije kring veelal uitgesloten zal zijn.

132 TK 12897 , no. 3 , p. $4 / 5$.

133 Men kan hier ook denken aan op naam gestelde preferente beschermingsaandelen, prioriteitsaandelen of gecertificeerde aandelen op naam. 
waarmee de preferente beschermingsaandelen zijn genomen), ontstaat een, in ieder geval ten tijde van de uitgifte, ongewenste situatie. ${ }^{134}$

Dat de naamloze vennootschap een grote vrijheid wordt gelaten andersluidende statutaire bepalingen te creëren ten aanzien van de overgang van stemrecht verbonden aan verpande aandelen op naam, blijkt uit de laatste zin van art. 89 lid $3 \mathrm{BW}$ :

"Van het bepaalde in de voorgaande drie zinnen kan in de statuten worden afgeweken."

Zo kan statutair worden bepaald dat het stemrecht nimmer kan toekomen aan de pandhouder van aandelen aan toonder, of aan degene die een pandrecht houdt op niet geblokkeerde aandelen op naam, danwel op aandelen op naam waarvan de overdracht aan de betrokken pandhouder niet door een blokkeringsregeling wordt getroffen. Ook kan een naamloze vennootschap in haar statuten bepalen dat er geen goedkeuring, door het daartoe aangewezen orgaan, vereist is voor het toekennen van het stemrecht aan een pandhouder, aan wie de geblokkeerde aandelen niet vrijelijk kunnen worden overgedragen. Andere statutaire bepalingen zijn ook toegestaan.

\section{b. De besloten vennootschap}

Voor de overgang van het stemrecht van aandeelhouder naar pandhouder geeft art. 198 lid 2 BW een eensluidende regeling als voor de overgang van stemrecht bij de naamloze vennootschap. Het stemrecht komt toe aan de pandhouder indien dit bij de vestiging van het pandrecht is bepaald en de pandhouder een persoon is aan wie de aandelen vrijelijk kunnen worden overgedragen. Verschil met art. 89 lid $3 \mathrm{BW}$, eerste zin is de verwijzing naar de blokkeringsregeling (art. 195 lid 1 $\mathrm{BW}$ ) in het derde lid van art. $198 \mathrm{BW}$.

Is de pandhouder een persoon aan wie de aandelen niet vrijelijk kunnen worden overgedragen, dan komt hem het stemrecht slechts toe indien dit bij de vestiging van het pandrecht is bepaald en deze vestigingsmodaliteit is goedgekeurd door het vennootschapsorgaan dat bij de statuten is aangewezen om goedkeuring te verlenen aan de overdracht van aandelen. Is er statutair geen orgaan aangewezen, dan dient de goedkeuring te worden verleend door de algemene vergadering van aandeelhouders.

De bevoegdheid tot het toekennen van stemrecht aan de pandhouder kan statutair worden uitgesloten.

Vergelijken we beide artikelen, dan blijkt dat de leden 3 met name verschillen doordat ze andere slotzinnen bevatten. De slotzin van art. 89 lid 3 BW biedt, zoals wij zagen, de mogelijkheid een statutaire regeling te ontwerpen die in haar

134 Zie omtrent verpanding van preferente beschermingsaandelen $\S$ II.7.4. 
totaliteit afwijkt van de wettelijke regeling. De vennootschap wordt in principe vrij gelaten te bepalen hoe zij de regeling van de overgang van het stemrecht wenst te zien. Daarentegen bepaalt de slotzin van art. 198 lid 3 BW dat de statuten de bevoegdheid tot het toekennen van het stemrecht aan de pandhouder kunnen uitsluiten. Dit laatste betekent dat, indien men statutair wil afwijken van de wettelijke regeling ten aanzien van overgang van stemrecht verbonden aan verpande aandelen in een besloten vennootschap, dit slechts mogelijk is door te bepalen dat het stemrecht in het geheel niet kan overgaan. Een andere afwijking is niet toegestaan. Zou de wetgever ten aanzien van de stemrechtovergang van aandeelhouder naar pandhouder een systeem hebben gekozen gelijk aan dat van art. 89 lid $3 \mathrm{BW}$, slotzin, dan zou dat betekenen, dat door middel van verpanding van aandelen, de verplichte blokkeringsregeling bij de besloten vennootschap omzeild kan worden. De eigendom van de aandelen blijft weliswaar bij de aandeelhouder, het stemrecht kan evenwel onder een derde worden gebracht. Hierdoor kan het besloten karakter van het samenwerkingsverband van aandeelhouders gefrustreerd worden. ${ }^{135}$ De strekking van de slotzin van het derde lid van art. $198 \mathrm{BW}$ is naar mijn mening dan ook "het waarborgen van de beslotenheid'. Bij een echt besloten samenwerkingsverband dient immers het uitgangspunt te zijn dat altijd volstrekt duidelijk is bij wie zich het stemrecht verbonden aan de aandelen bevindt. Bij de naamloze vennootschap zien we dat de wetgever gekozen heeft voor een vrijere regeling, ten aanzien van de werkelijk besloten vennootschap dient echter, in de visie van de wetgever, vast te worden gehouden aan een strakkere lijn.

135 Voor de effecten en gevolgen van de bepalingen van de leden 3 van de art. 89/198 BW op het karakter van de naamloze vennootschap en de besloten vennootschap verwijs is naar hetgeen hieromtrent wondt opgemerkt in § II.7. 


\section{I.7 Aandeelhoudersrechten; pandhoudersrechten}

Aandelen ${ }^{136}$ worden gehouden door aandeelhouders. Aandeelhouders zijn natuurlijke- of rechtspersonen die voor één of meer aandelen in het kapitaal van de vennootschap deelnemen.

Met betrekking tot de relatie tussen de aandeelhouder en de vennootschap merkt Schwarz ${ }^{137}$ op:

"De relatie tussen de aandeelhouder en de vennootschap kan worden gekwalificeerd als een lidmaatschapsverhouding, welke lidmaatschapsverhouding tussen aandeelhouder en vennootschap over en weer rechten en verplichtingen doet ontstaan."

Verder stelt Schwarz ${ }^{138}$ :

"De lidmaatschapsverhouding tussen aandeelhouder en (...) vennootschap komt tot stand door toetreding van de aandeelhouder tot de vennootschap. Op het moment van de toetreding ontstaan voor de aandeelhouder, ten opzichte van de vennootschap, rechten en plichten. Bepalend voor het bestaan van het aandeelhouderschap is deelneming in het kapitaal van de vennootschap. Uit deze deelneming vloeit jegens de vennootschap de, eventueel latente, verplichting tot volstorting van de door de aandeelhouder gehouden aandelen voort. ${ }^{n 139}$

Tegenover de stortingsplicht, waaraan aandeelhouders moeten voldoen, staan rechten. Zo hebben zij stemrecht in de algemene vergadering van aandeelhouders (art. 118/228 BW). Voorts zijn de aandeelhouders gerechtigd tot een gedeelte van de winst, naar evenredigheid van het aantal aandelen dat zij houden en voorzover de statuten de winstbestemming niet anderszins vastleggen of de algemene vergadering van aandeelhouders geen andere bestemming geeft aan de winst dan

136 Art. 79 lid 1/190 BW bepaalt dat: "Aandelen zijn de gedeelten, waarin het maatschappelijk kapitaal bij de statuten is verdeeld."

137 C.A. Schwarz, diss. p. 71/72 en de aldaar, in noot 4 angehaalde literatuur. Zie bijvoorbeeld ook Pitlo/Löwensteyn, Rechtspersonenrecht, $3^{\mathrm{e}}$ druk, $\$ 4.41$ : "Wat het rechtskarakter van de verhouding aandeelhouder-vennootschap betreft kunnen wij hetzelfde te berde brengen als hierboven ( $\$ 2.24$ ), waar wij spraken over de relatie tussen vereniging en lid. Wij zien geen reden om de aanspraak op dividend en stortingsplicht niet te beschouwen als een verbintenis uit overeenkomst, welke overeenkomst tot stand komt bij de plaatsing van het aandeel." Zie verder Handboek (1992), no. 131: "De toetreding van de oprichter tot de vennootschap (maar ook de aandeelhouder bij toetreding na oprichting; $\mathrm{JH}$ ) doet een lidmaatschapsverhouding ontstaan tussen vennootschap en oprichter (aandeelhouder; $\mathrm{JH}$ )."

138 C.A. Schwarz, diss. p. 74.

139 In andere zin F.K. Buijn, De oprichting van de NV en de BV, diss. p. 8-9. 
uitkering ervan aan aandeelhouders ${ }^{140}$, aldus de artt. 105 en 216 BW. Bovendien hebben aandeelhouders, met uitzondering van de houders van preferente(tenzij dit preferente winstdelende aandelen zijn) en prioriteitsaandelen, recht op een gedeelte van het liquidatiesaldo in geval van vereffening van de vennootschap (artt. 23 jo 23b BW).

Naast deze drie 'hoofdrechten' is er nog een aantal andere aanspraken die aandeelhouders geldend kunnen maken. Deze aanspraken hangen allen samen met de eerder genoemde rechten.

Overeenkomstig de art. 112/222 BW kan iedere aandeelhouder een door de wet of de statuten voorgeschreven algemene vergadering van aandeelhouders bij elkaar roepen, indien het bestuur en de raad van commissarissen dit verzuimen te doen. De aandeelhouder heeft ook het recht de algemene vergadering bij te wonen en deel te nemen aan de aldaar gevoerde beraadslaging (art. 117/227 BW). Eveneens heeft hij recht op alle, door hem verlangde, inlichtingen van het bestuur en de raad van commissarissen, tenzij een zwaarwichtig belang zijdens de vennootschap zich daartegen verzet (art. 107/217 lid 2 BW). De aandeelhouder heeft ook een voorkeursrecht op te emitteren gewone aandelen naar evenredigheid van het gezamenlijke bedrag van zijn aandelen (art. 96a/206a BW). ${ }^{141}$ Naast deze rechten die de individuele aandeelhouder geldend kan maken, kent de wet ook een aantal rechten toe aan groepen van aandeelhouders en aan de gehele aandeelhoudersvergadering. ${ }^{.42}$

In geval van verpanding van aandelen speelt het stemrecht verbonden aan aandelen een belangrijke rol. Wordt in de akte van verpanding bepaald dat het stemrecht bij de pandhouder zal komen te liggen dan verliest de aandeelhouder, in beginsel, iedere vorm van zeggenschap in de vennootschap. ${ }^{143}$ De overdracht van het stemrecht aan de pandhouder heeft immers een privatief karakter. In de MvT valt hierover het volgende te lezen:

"(...). Daamaast moest nog een aantal problemen onder ogen worden gezien. In de eerste
plaats de vraag of de aandeelhouder - ongeacht het feit dat zijn aandeel met pand of
vruchtgebruik is belast en ongeacht het feit dat dit pand of vruchtgebruik het stemrecht
omvat - niet altijd het recht moet hebben om voorgelicht en gehoord te worden omtrent de
zaken der vennootschap. Het is redelijk hem daartoe dezelfde rechten toe te kennen als aan

140 W.J. Slagter, Compendium, $\$ 118.1$.

141 Art. 96a/206a lid 1, tweede en derde zin en de leden 2 en 3 geven aan wanneer de aandeelhouder geen voorkeursrecht heeft op te emitteren aandelen.

142 Voor een overzicht van deze rechten verwijs ik naar W.J. Slagter, Compendium, § 67.

143 De uitoefening van het stemrecht door de pandhouder brengt met zich mee dat dit recht dient te worden uitgeoefend in overeenstemming met de belangen van de pandgever/aandeelhouder. Dit vloeit voort uit de rechtsverhouding tussen pandgever en pandhouder, art. 3:243 lid $1 \mathrm{BW}$. 
houders van certificaten van aandelen die met medewerking ${ }^{144}$ der vennootschap zijn uitgegeven." 145

De wet bepaalt dan ook dat de aandeelhouder, die geen stemrecht heeft, en de pandhouder die stemrecht heeft, de rechten hebben die door de wet zijn toegekend aan de houders van met medewerking ener vennootschap uitgegeven certificaten van aandelen (art. 89/198 leden 4 BW, eerste zin) ${ }^{146}$ Deze rechten kunnen ook toekomen aan de pandhouder die geen stemrecht heeft. Op dit punt maakt de wet een onderscheid tussen aandelen in een naamloze vennootschap en aandelen in een besloten vennootschap. De pandhouder zonder stemrecht in een naamloze vennootschap heeft de rechten die toekomen aan houders van certificaten van aandelen die met medewerking van de vennootschap zijn uitgegeven, tenzij deze hem bij de vestiging of de overgang van het pandrecht of bij de statuten der vennootschap worden onthouden.

Ergo, aan de pandhouder van aandelen in een naamloze vennootschap die geen stemrecht op die aandelen heeft, komen door wetsduiding de rechten toe van de houders van met medewerking van de vennootschap uitgegeven certificaten. De statuten kunnen evenwel bepalen dat hem deze rechten niet toekomen. Bij de vestiging van het pandrecht of de overgang ervan kan ook worden bepaald dat de pandhouder deze rechten niet heeft.

De pandhouder zonder stemrecht in een besloten vennootschap heeft deze rechten slechts, indien de statuten dit bepalen en bij de vestiging of overgang van het pandrecht niet anders is bepaald. Bij de besloten vennootschap liggen de kaarten dus anders. De statuten van een besloten vennootschap dienen uitdrukkelijk te bepalen dat de pandhouder zonder stemrecht dezelfde rechten heeft als de houder van certificaten die met medewerking van de besloten vennootschap zijn uitgegeven. Daarbij dient opgemerkt te worden dat, ook al bepalen de statuten van de besloten vennootschap dat aan de pandhouder de rechten van houders van bewilligde certificaten toekomen, van deze statutaire regeling afgeweken kan worden bij de akte van vestiging van het pandrecht of bij de overgang van het pandrecht. De achtergrond van deze regeling kan geen andere zijn dan dat de wetgever op deze wijze het karakter van de besloten vennootschap wil bescher-

$144 \mathrm{Zie}$ omtrent de vraag wanneer aandelen met medewerking van de vennootschap zijn uitgegeven F.J.P. van den Ingh, diss. 1991. Zie voor een reactie op de zienswijze van Van den Ingh, C.A. Schwar, Enkele vragen bij certificering van aandelen, TVVS 1992, p. 6 e.v. met reactie van Van den Ingh, TVVS 1992, p. 77-78. Zie ook $\$ 1.10 .3$.

145 TK 12897 , no. 3, p. 5.

146 Aan de houders van certificaten die met medewerking van de vennootschap zijn uitgegeven komen de volgende rechten toe: inzage in de jaarstukken van de vennootschap (art. 103/212), bijeenroeping van de algemene vergadering met éen tiende van het geplaatste kapitaal (art. $110 / 220$ lid 2), oproeping tot de algemene vergadering (art. 113/223 lid 2), bijwoning van de algemene vergadering, en aldaar het woord voeren (art. 117/227 lid 2) en uitlokken van een enquête door één rende van, of $f 500.000,=$ in, het geplaatste kapitaal (art. 346). 
men. In de ogen van de wetgever wordt het verkrijgen van de rechten van houders van bewilligde certificaten door de pandhouder gezien als een inbreuk op het besloten karakter van de vennootschap. Deze overweging komt mij bijzonder terecht voor. Immers, de pandhouder woont dan bijvoorbeeld de vergadering bij. Bij werkelijk besloten vennootschappen zal dit statutair steeds zijn uitgesloten.

Is er overeenkomstig art. 86c lid $4 \mathrm{BW}$ een 'stil' pandrecht op aandelen op naam gevestigd ${ }^{147}$, dan komen de pandhouder noch het stemrecht noch de rechten van certificaathouders toe. De aan de pandhouder, bij pandakte, toegekende rechten kan hij eerst dan uitoefenen wanneer de pandakte aan de vennootschap is afgegeven. Dan immers gaat het 'stille' karakter van het pandrecht verloren. Voor de mogelijke overgang van het stemrecht van pandgever naar pandhouder gelden natuurlijk de reeds eerder beschreven vereisten. ${ }^{148}$

147 Zie ook \$ I.5.2.1.

$148 \mathrm{Zie} \S \mathrm{I} .6$. 


\section{I.8 Goederenrechtelijke bevoegdheden en verplichtingen van de pandhouder}

In de vorige paragraaf is voornamelijk gesproken over de rechten en plichten die, krachtens Boek 2 BW, aan de aandeelhouder/pandgever en aan de pandhouder toekomen. De aldaar besproken rechten en verplichtingen, waarvan het stemrecht ongetwijfeld het belangrijkste is, zijn direct verbonden met het aandeel. $\mathrm{Zij}$ vloeien er direct uit voort. In deze paragraaf zullen de rechten en verplichtingen van de pandhouder besproken worden die afgeleid zijn van het beperkt zekerheidsrecht van pand, gevestigd op aandelen.

Ten aanzien van de rechten en plichten hieronder besproken onder $a, b$ en $c$ het volgende. De wet spreekt in art. 243 van Boek 3 BW over een 'zaak'. ${ }^{149}$ Strikt genomen zouden de genoemde rechten en plichten dus niet van toepassing zijn wanneer een pandrecht op een aandeel wordt gevestigd. Een aandeel is immers geen zaak. In de M.v.A. II op art. 3.9.2.5 (art. 3:243 BW) ${ }^{150}$ lezen we echter dat het artikel ook ziet op het geval dat een recht aan toonder of order is verpand. In dat geval geldt de zorgverplichting voor het verpande toonder- of orderpapier. ${ }^{151}$ Wanneer in het hiernavolgende onder $a, b$ en $c$ gesproken wordt van een 'zaak' c.q. een aandeel wordt gedoeld op een bewijs van een aandeel aan toonder of een aandeel op naam in een naamloze vennootschap.

\section{a. Het recht van tenughouding van het aandeel}

Wanneer op een aandeel op naam een openbaar pandrecht wordt gevestigd, is de pandhouder bevoegd het verpande aandeel onder zich te houden. Hij hoeft het aandeel slechts af te geven nadat de vordering, tot zekerheid waarvan het pandrecht is gevestigd, is voldaan. Deze regel vloeit voort uit art. 3:256 BW..$^{152}$ Deze bevoegdheid komt ook toe aan de houder van een pandrecht op een aandeel dat in eerste instantie stil werd gevestigd, maar later in de macht van de pandhou-

149 In art. 3:256 BW wordt gesproken van een 'goed'. Hieromtrent wordt in het V.V. II (Van Zeben, Du Pon (I), p. 788) opgemerkt dat: "In het eerste lid zal men niet van een "zaak" maar van een "goed" moeten spreken, aangezien immers onder meer (curs.JH) ook orderpapier in pand kan worden gegeven." Art. 256 van Boek 3 kan m.i. dus ook van toepassing zijn indien het bewijs van een aandeel aan toonder in pand wordt gegeven.

150 Van Zeben, Du Pon (I), p. 768.

151 Zie ook F. Molenaar, Pandrecht, Mon. Nieuw BW, B12a, $2^{e}$ druk, 1991, p. 67. Aldaar lezen wij: "Ook kan onder het artikel (art. 3:243 BW,JH) worden gebracht de zorg, die de bouder van een toonderpapier, dat de belichaming vormt van een in pand gegeven vorderings-, lidmaatschaps- of aandeelhoudersrecht (curs.JH), moet betrachten ten aanzien van het papier zelve, te weten zorgen dat het niet beschadigd wordt, niet zoek raakt e.d."

152 Zie Asser-Mijnssen, Zakenrecht III, nr. 44. 
der of een derde is gebracht overeenkomstig het bepaalde in art. 3:237 lid $3 \mathrm{BW}$. Naar huidig recht strekt een pandrecht tot zekerheid van een vordering tevens tot zekerheid voor drie jaren rente die over deze vordering krachtens overeenkomst of wet is verschuldigd. Partijen kunnen evenwel anders overeenkomen. ${ }^{153}$

\section{b. Zorgplicht ten aanzien van het verpande aandeel}

Op de pandhouder rust een zorgplicht ten aanzien van het verpande aandeel. De wet bepaalt in het eerste lid van art. 3:243 BW dat hij, die uit hoofde van een pandrecht een zaak onder zich heeft, als een goed pandhouder voor de zaak moet zorg dragen. De sanctie op het niet naleven van deze zorgplicht vindt men in art. 3:257 BW. Indien degene die uit hoofde van een pandrecht een zaak onder zich heeft, in ernstige mate in de zorg voor de zaak tekort schiet, kan de rechtbank op vordering van de pandgever of een pandhouder bevelen dat de zaak aan een van hen wordt afgegeven of in gerechtelijke bewaring van een derde wordt gesteld.

Hoe kan men nu tekortschieten in de zorg ten aanzien van een aandeel in een kapitaal vennootschap? Ik zou menen dat de houder van een pandrecht op aandelen in een vennootschap in ernstige mate tekortschiet in de zorgplicht die op hem rust wanneer hij de aandelen vervreemd, anders dan door executie. ${ }^{154}$

\section{c. Recht op vergoeding van de kosten gemaakt tot onderhoud en behoud van het verpande aandeel}

Krachtens het tweede lid van art. 3:243 BW strekt het pandrecht tot zekerheid van de hoofdvordering en, daarnaast, tot voldoening van de kosten die door de pandhouder zijn gemaakt tot behoud en tot onderhoud van de verpande zaak. De door de pandhouder gemaakte kosten moeten hem door de pandgever worden terug betaald. Het pandrecht strekt mede tot zekerheid daarvoor. Andere door de pandhouder ten behoeve van het pand gemaakte kosten kan hij van de pandgever slechts terugvorderen, indien hij ze met toestemming van de pandgever heeft gemaakt.

Heeft de pandhouder uit hoofde van een pandrecht een zaak onder zich, dan moet hij als een goed pandhouder voor de zaak zorg dragen. De door de pandhouder betaalde kosten tot behoud en tot onderhoud moeten hem door de pandgever worden terugbetaald. Het pandrecht strekt mede tot zekerheid daarvoor.

Aan welke kosten kunnen we denken wanneer we spreken over 'kosten tot instandhouding van het pand'? Het volgende geval brengt duidelijkheid.

153 Aldus art. 3:244 BW.

154 Zie ook Asser-Mijnssen, Zakenrecht III, nr. 46. 
Aandeelhouder A heeft een pandrecht op zijn aandelen in een naamloze vennootschap gevestigd ten behoeve van $B$. In de pandakte is bepaald dat het stemrecht verbonden aan de verpande aandelen door de pandgever (A) wordt uitgeoefend. De statuten van de vennootschap bepalen dat aan de pandhouder die geen stemrecht heeft de rechten toekomen van de houders van bewilligde certificaten, terwijl bij de vestiging van het pandrecht niet anders is bepaald. Tijdens een aandeelhoudersvergadering stemt $\mathrm{A}$ voor een besluit tot emissie van aandelen met uitsluiting van het voorkeursrecht. Ten gevolge van dit besluit daalt de waarde van de aandelen in het algemeen. Ook de waarde van het pand neemt af.

Naar mijn mening kan de pandhouder in rechte vorderen dat het besluit waardoor het door hem gehouden pand in waarde daalt vernietigd wordt, indien de pandhouder kan aantonen dat dit besluit in strijd is met de eisen van redelijkheid en billijkheid die door art. $8 \mathrm{BW}$ worden gesteld. De kosten die dit proces met zich brengen zouden mijns inziens op de pandgever kunnen worden verhaald, als zijnde kosten tot behoud en onderhoud van het pand.

Meer in het algemeen vallen de kosten die bewaargeving van effecten (toonderstukken), waarop een openbaar pandrecht is gevestigd, met zich mee brengt naar mijn mening eveneens onder de kosten als bedoeld in het tweede lid van art. $3: 243 \mathrm{BW}$.

Een andere verplichting van de pandhouder geeft art. 3:241 BW:

"De pandhouder is verplicht desgevorderd aan de pandgever een schriftelijke verklaring af te geven van de aard en, voor zover mogelijk, het bedrag van de vordering waarvoor het verpande tot zekerheid strekt."

Anders dan bij hypotheek kende het ontwerp Meijers, ten aanzien van pandrecht, geen verplichting dat het bedrag van de vordering waarvoor zekerheid wordt gegeven bij de vestiging van het pandrecht moet vaststaan. ${ }^{155}$ Niettemin is ook de pandgever er bij gebaat te weten welk bedrag door het pandrecht wordt gedekt. Dit kan van belang zijn indien de pandgever, op het zelfde goed, een tweede pandrecht wenst te vestigen en hij de tweede pandhouder dient in te lichten betreffende de hoogte van het bedrag dat door het eerste pandrecht wordt gedekt. Het bedrag van de vordering waarvoor het pandrecht tot zekerheid dient, kan immers gedurende de looptijd van het pandrecht veranderen. De hoogte van de door het pandrecht gegarandeerde vordering kan afnemen door aflossing. Men denke ook aan het feit dat de pandhouder gerechtigd is tot het innen van het

155 Van Zeben, Du Pon (I), M.v.A. II an. 3.9.2.3b, p. 765. 
dividend dat wordt uitgekeerd op het verpande aandeel. Hij zal dit in mindering dienen te brengen op de aan hem verschuldigde interessen of op de hoofdsom. Het claimrecht verbonden aan het verpande aandeel valt onder het pandrecht. De pandhouder zal dit recht echter niet mogen uitoefenen danwel te gelde maken (het claimrecht is geen vrucht van het aandeel), tenzij bij wijze van executie of met toestemming van de pandgever/aandeelhouder. De pandhouder zal de aandeelhouder de gelegenheid moeten geven het recht zelf uit te oefenen of te gelde te maken, mits de verkregen opbrengst onder het pandrecht wordt gebracht. ${ }^{156}$ Anderzijds kan het verzekerde bedrag stijgen ten gevolge van rente krachtens overeenkomst of wet verschuldigd (art. 3:244 BW), danwel doordat de pandhouder ten behoeve van het behoud van het verpande goed bepaalde kosten heeft moeten maken (art. 3:243 lid 2 BW).

\section{d. Verandering van de aard van het pandrecht}

Tenzij partijen anders overeengekomen zijn is de pandhouder bevoegd, overeenkomstig art. 3:237 lid $3 \mathrm{BW}$, te vorderen dat het toonder papier in zijn macht of in die van een derde wordt gebracht, indien de pandgever in zijn verplichtingen jegens de pandhouder tekortschiet of hem goede grond geeft te vrezen dat in die verplichtingen zal worden te kort geschoten. Het bezitloos pand verandert dan in een vuistpand door afgifte van het goed. Ten gevolge van gelijke omstandigheden verandert een stil pand op een recht op naam in een openbaar pand door van de verpanding mededeling te doen aan de debiteur van de verpande vordering (art. 3:239 lid $3 \mathrm{BW}$ ).

Alvorens in te gaan op de vraag of de houder van een pandrecht op een aandelen in een kapitaalvennootschap bevoegd is over te gaan tot herverpanding van het aandeel wordt de vraag gesteld hoe te oordelen omtrent de toepasselijkheid van de hierboven beschreven rechten en verplichtingen indien aandelen op naam in een besloten vennootschap voorwerp van verpanding zijn.

Naar de letter van de wet zou de houder van een pandrecht op een aandeel op naam geen beroep kunnen doen op de eerder genoemde rechten en zou de verplichting van het eerste lid van art. 3:243 BW niet voor hem gelden. Een aandeel op naam is immers geen zaak. Het is een recht. Bovendien is dit recht niet belichaamd in een papier; de besloten vennootschap mag geen aandeelbewijzen uitgeven. Desalniettemin ben ik van mening dat, uit oogpunt van bescherming

156 Zie Handboek (1992), no. 184. In andere zin P. van Schilfgaarde, Van de BV en de NV, $10^{\circ}$ druk, ar. 40: "Op stockdividenden, bonusaandelen en claims etc. kan m.i. art. 246 Boek 3 zonder bezwaar worden toegepast: de pandhouder kan de stukken (rechten) in ontvangst nemen, de pandrechten komen mede daarop te rusten." 
van de rechten van de pandhouder, de houder van een pandrecht op een aandeel op naam in een besloten vennootschap onverkort een beroep kan doen op de rechten die voortvloeien uit de artt. 3:256 $6^{157}$ en 243 lid 2 BW.

Ten aanzien van de verplichting neergelegd in het eerste lid van art. 3:243 BW het volgende. Wanneer een pandrecht wordt gevestigd op en aandeel op naam in een besloten vennootschap geschiedt zulks door middel van een notariële akte, waama de vestiging van het pandrecht door de vennootschap dient te worden erkend, danwel de akte aan de vennootschap dient te worden betekend. Naam en adres van de pandhouder worden door het bestuur van de vennootschap ingeschreven in het aandeelhoudersregister. ${ }^{158}$ Echter, het verpande goed komt niet in de macht van de pandhouder. Zijn zorgplicht zal dan ook uiterst gering zijn. De vrees voor vervreemding van de aandelen, anders dan door executie, zal hier niet spelen gezien het feit dat de pandhouder geen feitelijke macht over het pand kan uitoefenen.

\section{e. Bevoegdheid tot herverpanding}

Art. 3:242 BW bepaalt betrekkelijk de bevoegdheid tot herverpanding van goederen:

"Een pandhouder is niet bevoegd het goed dat hij in pand heeft, te herverpanden, tenzij deze bevoegdheid hem ondubbelzinnig is toegekend."

Partijen zijn bevoegd overeen te komen dat de pandhouder het verpande goed mag herverpanden. Bij de herverpanding wordt een tweede pandrecht op het zelfde goed gevestigd. De eerste pandhouder behoudt de beschikking over het verpande goed, daar de tweede pandhouder als houder voor de eerste pandhouder optreedt. ${ }^{159}$ De idee achter de herverpanding door de eerste pandhouder is dat hij zijn pandrecht achter stelt bij dat van de tweede pandhouder. De eerste pandhouder zal, ten tijde van het bestaan van de herverpanding, niet tot executie van zijn pandrecht overgaan. Indien de eerste pandhouder zijn schuld ten opzichte van de tweede pandhouder af lost, herleeft het eerste pandrecht. ${ }^{160}$

157 Art. 3:256 BW spreekt niet van een 'zaak', maar van een 'goed'.

158 Indien het pandrecht op de aandelen stil wordt gevestigd vindt geen erkenning door of betekening aan de vennootschap plaats. Het bestuur kan dientengevolge de gegevens van de pandhouder niet opnemen in het aandeelhoudersregister.

159 Zie Van Zeben, Du Pon (T). T.M. art. 3.9.2.4, p. 766. Zie omtrent de bevoegdheid tot herverpanding ook Asser-Mijnssen, Zakenrecht III, nss. 38/39; F. Molenaar, Pandrecht, Mon. NBW B12a, $2^{\mathrm{e}}$ druk, 1991, p. 69/70.

160 Zie Asser-Mijnssen, Zakenrecht III, nr. 38. 
Hoe nu te oordelen over de herverpanding van aandelen. Betrekkelijk de herverpanding van toonderaandelen en aandelen op naam in 'open' naamloze vennootschappen zie ik geen problemen. ${ }^{161}$

Dit is anders ten aanzien van de herverpanding van aandelen op naam in besloten vennootschappen en besloten naamloze vennootschappen. In beginsel zou ik er vanuit willen gaan dat herverpanding van aandelen op naam, met overgang van het stemrecht verbonden aan die aandelen, slechts onder strikte voorwaarden toelaatbaar is. Immers, de idee van de herverpanding is niet zonder meer verenigbaar met het karakter van de besloten (naamloze) vennootschap. Doordat aan een pandhouder de bevoegdheid tot herverpanding wordt gegeven, met overgang van stemrecht, kan immers het besloten karakter van de vennootschap worden doorbroken.

Betrekkelijk die eisen zou ik willen aansluiten bij het bepaalde in het derde lid van art. $198 \mathrm{BW}$. Het recht van herverpanding van op naam gestelde BVaandelen, met gelijktijdige overgang van stemrecht, zou ik toelaatbaar achten indien de tweede pandhouder een persoon is die tot de vrije kring behoort als gesteld in het eerste lid van art. $195 \mathrm{BW}$. Veelal zal deze kring zijn uitgesloten. Alsdan dienen de tweede en derde zin van genoemd lid in de strijd te worden geworpen. Het stemrecht komt de tweede pandhouder slechts toe indien zulks bij de vestiging van het pandrecht is bepaald en de vestiging van het pandrecht, inclusief de overgang van het stemrecht, door de algemene vergadering is goedgekeurd. De wet spreekt van "goedkeuring door het vennootschapsorgaan dat bij de statuten is aangewezen om goedkeuring te verlenen tot een voorgenomen overdracht van aandelen". Echter in het geval waarbij aandelen op naam in een besloten (naamloze) vennootschap door de eerste pandhouder worden herverpand met overgang van het stemrecht, zou ik de eis willen stellen dat de goedkeuring van de herverpanding dient te worden verleend door de algemene vergadering van aandeelhouders. Dit is immers het orgaan dat erop toe dient te zien dat het besloten karakter van de vennootschap wordt gewaarborgd. Vanzelfsprekend dient ook bij de herverpanding, indien mogelijk ${ }^{162}$, te worden voldaan aan de wettelijke en statutaire vereisten voor de vestiging van het pandrecht door de eerste pandhouder.

Interessant is de vraag naar de positie van de eerste pandhouder wanneer de tweede pandhouder overgaat tot executie van zijn pandrecht. Ten gevolge van de

161 Zie omtrent herverpanding van effecten, Asser-Mijnssen, Zakenrecht III, nr. 39.

162 Zoals reeds eerder werd opgemerkt is de pandhouder slechts bevoegd tot herverpanding indien deze bevoegdheid hem ondubbelzinnig is toegekend. In de literatuur wordt deze ondubbelzinnigheid ingevuld door 'toestemming van de pandgever' (zie Asser-Mijnssen, Zakenrecht III, nr. 38). Betrekkelijk de herverpanding van aandelen op naam in besloten (naamloze) vennootschappen lijkt mij de eis op zijn plaats dat de eventuele bevoegdheid tot herverpanding in de statuten van de vennootschap moet zijn opgenomen. 
bevoegdelijk geschiedde herverpanding door de eerste pandhouder/tweede pandgever aan de tweede pandhouder vervalt het eerste pandrecht niet. Het pandrecht dat door de pandhouder wordt gevestigd komt in rang boven zijn pandrecht. Dit is tevens het geval wanneer het tweede pandrecht stil wordt gevestigd. ${ }^{163}$ Molenaar $^{164}$ merkt op:

\begin{abstract}
"Wordt het pand door de tweede pandnemer geëxecuteerd, dan kan de eerste pandnemer zijn recht van voorrang doen gelden op het overschot. (...) Hier moge aan worden toegevoegd dat de eerste pandnemer tegenover de eerste pandgever wanprestatie pleegt indien hij het op een executie door de tweede pandnemer laat aankomen op een moment, dat de eerste pandgever niet in gebreke is. Hij kan dan immers niet meer voldoen aan zijn verplichting om de eerste pandgever de feitelijke macht over het goed terug te geven op het moment dat deze aan zijn verplichtingen jegens hem beeft voldaan en bet pandrecht derhalve is geëindigd (art. $256 \mathrm{BW}$ )."
\end{abstract}

Hoe nu te oordelen over het aan de pandhouder toegekende recht van het eerste lid van art. 3:251 BW in geval van herverpanding van aandelen op naam in een besloten (naamloze) vennootschap? In dit artikellid wordt bepaald dat de president van de rechtbank, op verzoek van de pandgever of de pandhouder, kan bepalen dat het pand zal worden verkocht op een andere wijze dan door openbare verkoop naar de plaatselijke gewoonten en op de gebruikelijke voorwaarden, of, op verzoek van de pandhouder, kan bepalen dat het pand voor een door de president te bepalen bedrag aan de pandhouder zal verblijven. In het licht van dit artikel is een tweetal situaties te onderscheiden.

In het eerste geval is de eerste pandgever/aandeelhouder in gebreke in zijn verhouding tot de eerste pandhouder, ten gevolge waarvan de eerste pandhouder/tweede pandgever in gebreke komt in zijn relatie to de tweede pandhouder. In dit geval acht ik de tweede pandhouder bevoegd de president van de rechtbank te verzoeken te bepalen dat de verpande aandelen voor een door de rechter vast te stellen prijs aan de tweede pandhouder zullen verblijven. De eerste pandhouder/tweede pandgever zal zich, indien mogelijk, kunnen verhalen op het overschot.

In het tweede geval, het geval waarin de eerste pandgever/aandeelhouder ten opzichte van de eerste pandhouder niet in gebreke is, maar de eerste pandhouder/tweede pandgever wel tekortschiet in zijn lossingsverplichting jegens de tweede pandhouder, die dien ten gevolge tot executie van het pand overgaat, dient de president van de rechtbank, naar mijn mening, negatief te beslissen op het verzoek tot verblijving van de aandelen aan de tweede pandhouder. Staat de president toe dat de aandelen, tegen een door hem vast te stellen bedrag, aan de

163 Aldus Asser-Mijnssen, Zakenrecht III, nr. 38

164 F. Molenaar, Pandrecht, Mon. Nieuw BW, B12a, $2^{e}$ druk, 1991, p. 69. 
tweede pandhouder verblijven dan kunnen de in pand gegeven aandelen niet meer in de feitelijke macht van de rechthebbende eerste pandgever/aandeelhouder worden teruggebracht wanneer deze laatste zijn verplichtingen jegens de eerste pandhouder/tweede pandgever nakomt, waardoor het eerste pandrecht komt te vervallen. Hierdoor pleegt, gelijk Molenaar opmerkte, de eerste pandhouder/tweede pandgever wanprestatie jegens de eerste pandgever/aandeelhouder. Deze wanprestatie leidt tot schadevergoeding aan de aandeelhouder/eerste pandgever. Het komt mij voor dat het verlies van de aandelen, en dus het verlies van de lidmaatschapsverhouding, door de eerste pandgever/aandeelhouder nimmer, door welk bedrag aan schadevergoeding dan ook, kan worden gecompenseerd. Opmerking verdient het feit dat de feitelijke verblijving van de aandelen aan de tweede pandhouder onderworpen zal zijn aan de statutaire blokkeringsregelingen. Hierdoor kan wellicht veel leed worden voorkomen. 
Eerder in dit hoofdstuk werd gesproken over de verhouding tussen aandeelhouder en vennootschap. Deze verhouding werd omschreven als een lidmaatschapsverhouding. Elementen als "toetreding van de aandeelhouder tot de vennootschap", "het ontstaan van rechten en plichten voor de aandeelhouder ten opzichte van de vennootschap" en "deelneming in het kapitaal van de vennootschap" vormen criteria $^{165}$ voor het feit of een bepaalde vennootschappelijke verhouding al dan niet gezien moet worden als een lidmaatschapsverhouding.

De vraag is nu hoe de relatie pandhouder - vennootschap kan worden gekwalificeerd. Deze kwalificatie is met name van belang voor de vraag of de pandhouder behoort tot de kring van art. 8 in relatie tot art. 15 lid 1 sub b BW.

De pandhouder heeft, afhankelijk van de omstandigheden van het concrete geval, de rechten die toekomen aan de houders van met medewerking der vennootschap uitgegeven certificaten van aandelen. ${ }^{166}$ Binnen het organisatorische verband van de kapitaalvennootschap kan de pandhouder dus, onder omstandigheden, een aantal min of meer belangrijke rechten geldend maken. Dit gegeven rechtvaardigt mijns inziens de vraag naar de relatie tussen de houder van een pandrecht op aandelen en de vennootschap die de betreffende aandelen heeft uitgegeven. Is deze relatie te kwalificeren als een lidmaatschapsverhouding, een organisatierechtelijke betrekking, zoals de relatie tussen de aandeelhouder en de vennootschap, of is er slechts sprake van een obligatoire verhouding tussen de pandhouder en de aandeelhouder?

Ik zou de zaak als volgt willen bezien. De vraag of er sprake is van een lidmaatschapsverhouding tussen pandhouder en vennootschap is afhankelijk van de aanwezigheid van een organisatierechtelijke betrokkenheid tussen beiden. De vraag of er sprake is van een zodanige betrokkenheid tussen pandhouder en vennootschap zal moeten worden beoordeeld aan de hand van feitelijke omstandigheden. De pandhouder $k a n$ in een organisatierechtelijke betrekking tot te vennootschap staan, welke situatie ik in ieder geval zou willen aannemen wanneer aan de pandhouder het stemrecht op de verpande aandelen, krachtens de pandovereenkomst, toekomt. In de gevallen waarin de pandhouder de rechten heeft die

165 Deze elementen zijn te vinden in de door (o.a.) C.A. Schwarz (diss. p. 71/72), M.J.A. van Mourik (NV 62 (1984), p. 200) en Handboek (1992), nr. 131) gegeven omschrijvingen van het begrip aandeelhouderschap.

$166 \mathrm{Zie} \S \mathrm{I} .7$. 
de wet toekent aan de houders van met medewerking der vennootschap uitgegeven certificaten van aandelen zou ik eveneens willen spreken van een organisatierechtelijke betrokkenheid tussen pandhouder en vennootschap. Tenslotte is denkbaar dat zo een organisatierechtelijke verhouding in het geheel niet waarneembaar is. De rechten die uit de organisatierechtelijke betrekking voortvloeien zou ik willen kwalificeren als organisatierechten c.q. lidmaatschapsrechten.

Laten we deze afzonderlijke vragen nader onder de loep nemen. Wanneer is er sprake van een organisatierechtelijke betrekking tussen de pandhouder en de vennootschap, wanneer kunnen we spreken van een pandhouder met lidmaatschapsrechten, wanneer behoort de pandhouder tot de kring van art. 8 jo $15 \mathrm{BW}$ ?

\section{a. De pandhouder heeft stemrecht}

De pandhouder die het stemrecht, het ultieme organisatie- c.q. lidmaatschapsrecht, heeft, heeft de rechten, die door de wet zijn toegekend aan de houders van met medewerking der vennootschap uitgegeven certificaten van aandelen, aldus lid 4 van de artt. 89 en 198 BW. In dit geval is er dus duidelijk sprake van een organisatorische betrokkenheid van de pandhouder in zijn relatie tot de vennootschap. Hem komt niet alleen het stemrecht verbonden aan de verpande aandelen toe, daarnaast kan hij enkele lidmaatschaps(organisatie)rechten doen gelden in zijn verhouding tot de vennootschap. De pandhouder, die gerechtigd is het stemrecht verbonden aan de verpande aandelen uit te oefenen, wordt dus betrokken in de organisatie van de rechtspersoon, er ontstaat een organisatierechtelijke betrekking, een lidmaatschapsverhouding.

Men zou in dit verband kunnen opperen dat niet van een lidmaatschapsverhouding gesproken kan worden. Immers, in tegenstelling tot de aandeelhouder en de houder van een bewilligd certificaat heeft de pandhouder geen directe binding met het aandeel dat hij in pand houdt. De aandeelhouder blijft, in beginsel, rechthebbende op het aandeel en het is de aandeelhouder die het kapitaal van de vennootschap heeft verschaft ${ }^{167}$, niet de pandhouder. Dit standpunt verdient naar mijn mening enige nuancering, namelijk voor het geval waarin het stemrecht wordt overgedragen aan de pandhouder. Immers, onder deze omstandigheden wordt de pandhouder toegelaten tot het samenwerkingsverband, hij wordt, zoals reeds eerder opgemerkt, betrokken in de organisatie van de rechtspersoon. De overige aandeelhouders, of een ander vennootschapsorgaan belast met het verlenen van toestemming betrekkelijk de vestiging van pandrecht met overgang van stemrecht, geven te kennen dat de pandhouder in het samenwerkingsverband 'mag meedoen'. Door het overdragen van het stemrecht gaat de pandhouder behoren tot de

167 In geval van certificering van aandelen in het de houder van het certificaat die, direct of indirect, het kapitaal van de vennootschap verschaft. 
kring van vergadergerechtigden. Tot eenzelfde conclusie vermag ik te komen wanneer niet het stemrecht aan de pandhouder toekomt, maar hij wel de rechten kan uitoefenen die de wet toekent aan de houders van bewilligde certificaten. Ook dan is de pandhouder een van de vergadergerechtigden. In het laatste geval is hij niet in staat het besluitvormingsproces rechtstreeks te beïnvloeden, wel kan hij door zijn recht ter vergadering te worden opgeroepen, aldaar te verschijnen en het woord te voeren zijn mede-vergadergerechtigden van zijn opvattingen overtuigen, hetgeen indirect van invloed kan zijn op het besluitvormingsproces binnen de vennootschap. ${ }^{168}$ De overgang van het stemrecht op de pandhouder betekent dat deze in een organisatierechtelijke betrekking tot de vennootschap komt te staan die gelijk is aan die van de aandeelhouder.

\section{b. De pandhouder heeft geen stemrecht}

In lid 2 van de artt. 89 en 198 BW wordt bij wijze van hoofdregel bepaald dat de aandeelhouder het stemrecht heeft op de verpande aandelen. In dit geval lijkt mij de zaak duidelijk. Ten gevolge van de verpanding ontstaat slechts een rechtsbetrekking tussen de aandeelhouder/pandgever en de pandhouder. De pandhouder staat in geen enkele betrekking tot de vennootschap. Er is dus geen sprake van een organisatorische betrokkenheid. Doordat de statuten van de vennootschap bepalen dat het stemrecht te allen tijde bij de aandeelhouder blijft, wordt voorkomen dat de pandhouder enige vorm van zeggenschap verkrijgt in de vennootschap. ${ }^{169}$ In beginsel is de situatie dus dat de pandhouder die geen stemrecht heeft geen enkel recht geldend kan maken ten opzichte van de vennootschap, hij staat slechts in een persoonlijke rechtsbetrekking tot de pandgever/aandeelhouder.

Dit is evenwel anders wanneer de pandhouder die geen stemrecht heeft de rechten kan uitoefenen die de wet toekent aan de houders van bewilligde certificaten. Bij de naamloze vennootschap is dit het geval tenzij deze rechten hem bij de vestiging of overgang van het pandrecht of bij de statuten van de vennootschap worden onthouden. Bij de besloten vennootschap heeft de pandhouder zonder stemrecht deze rechten slechts indien de statuten dit bepalen en bij de vestiging of de overgang van het pandrecht niet anders is bepaald. ${ }^{170}$ Door het toekennen van bepaalde organisatie- of lidmaatschapsrechten aan de pandhouder ontstaat

168 Zie omtrent de positie van de van stemloze vergadergerechtigden C.A. Schwarz, De invloed van vergadergerechtigden zonder stemrecht op besluitvorming in de aandeelhoudersvergadering, in: 'Heden verschenen voor mij...' (Liber Amicorum A.L.M. Soons), red. P.H.M. Gerver, J.G. Kuijl, A.J.H. Pleysier, R.T.G. Verstraaten, Amhem, 1995, p. $201-208$.

169 Het is niet noodzakelijk dat de statuten een dergelijke bepaling bevatten. Ten tijde van het vestigen van het pandrecht kan immers worden bepaald dat het stemrecht niet aan de pandhouder zal toekomen.

170 Zie de artt. 89/198 lid 4 slotzin BW. 
naar mijn mening, naast de persoonlijke rechtsbetrekking tussen aandeelhouder/pandgever en pandhouder, een organisatorische betrokkenheid tussen de pandhouder en de vennootschap. Het moge duidelijk zijn dat deze organisatierechtelijke betrekking minder sterk van aard is dan die waarbij de pandhouder tevens het stemrecht, verbonden aan de verpande aandelen, kan uitoefenen. Het al of niet kunnen uitoefenen van het stemrecht is dus bepalend voor de mate van organisatorische betrokkenheid.

\section{c. De relatie pandhouder en de artikelen 8 en 15 lid 2 sub b BW}

Wij komen nu aan de vraag of de pandhouder qualitate qua behoort tot de kring van art. 8 en art. $15 \mathrm{BW}$. In de $\mathrm{MvT}^{171}$ op art. $8 \mathrm{BW}$ lezen wij:

\footnotetext{
"Het eerste lid stemt overeen met het huidige art. 7. De tekst is wat vereenvoudigd en algemener gemaakt, overigens zonder wijziging van de strekking. Daar houders van met medewerking van een vennootschap zelf uitgegeven certificaten van aandelen bepaalde (aandeelhouders) rechten binnen het vennootschappelijk verband kunnen uitoefenen, kan men hen "bij de organisatie van de rechtspersoon betrokken" achten; hetzelfde geldt voor vruchtgebruikers en pandhouders van aandelen."
}

Volgens de MvT op het eerste lid van art. $8 \mathrm{BW}$ behoren pandhouders tot de organisatie van de rechtspersoon. Deze opvatting is mijns inziens te ruim van aard. Ik zou willen betogen dat slechts pandhouders die stemrecht hebben ${ }^{172}$ en pandhouders die geen stemrecht hebben, maar wel de rechten kunnen uitoefenen die de wet toekent aan de houders van bewilligde certificaten, behoren tot de kring van art. $8 \mathrm{BW}$. Deze stellingname heeft tot gevolg dat de houders van een pandrecht die gerechtigd zijn tot het stemrecht op de verpande aandelen en de pandhouders die dit niet zijn, maar wel beschikken over bepaalde andere aandeelhoudersrechten een beroep kunnen doen op art. 15 lid 1 sub b BW. Zij kunnen een besluit van een orgaan van de rechtspersoon doen vemietigen indien dit besluit in strijd is met de redelijkheid en billijkheid die door art. $8 \mathrm{BW}$ worden geëist.

171 J.M.M. Maeijer, Wetsgeschiedenis, LXt-Art. 8 - 1.

172 In gelijke zin Handboek (1992), nr. 172.1. 


\section{I.10 Pandrecht van certificaathouders}

\section{I.10.1 Inleiding}

In een monografie die handelt over verpanding van aandelen mogen enkele beschouwingen omtrent het - wettelijk - pandrecht ten behoeve van houders van certificaten van aandelen niet ontbreken.

Alvorens nader in te gaan op het wettelijk pandrecht en het 'gewoon' pandrecht, enkele woorden over certificering van aandelen. ${ }^{173} \mathrm{Al}$ snel zal duidelijk worden dat de termen bewilligd/onbewilligd certificaat en medewerking der vennootschap een grote rol spelen bij de vraag welke rechten al dan niet aan houders van certificaten worden toegekend. Een aparte paragraaf zal dan ook aan deze aspecten worden gewijd.

Ingegaan wordt voorts op de vraag hoe de relatie van de houders van certificaten van aandelen c.q. houders van een - wettelijk - pandrecht op gecertificeerde aandelen ten opzichte van de vennootschap kan worden gekwalificeerd. Bij de beantwoording van deze vraag zal met name worden uitgegaan van de artt. 8 en 15 van Boek 2 BW.

Het hoofdstuk wordt afgesloten met enkele beschouwingen aangaande de executie van het wettelijk pandrecht.

\section{I.10.2 Certificering van aandelen}

Aan het aandeel is een aantal rechten verbonden. Deze rechten kunnen worden onderscheiden in vermogensrechten (recht op dividenden, voorkeursrechten op nieuw uit te geven aandelen, recht op een deel van de liquidatiewinst) en zeggenschapsrechten (stemrecht, vergaderrechten, recht op informatie). ${ }^{174}$ In beginsel kunnen de aandeelhouders, door het uitoefenen van de aan hen toekomende zeggenschapsrechten, het beleid binnen de vennootschap mede bepalen. De aandeelhouders zijn onder andere bevoegd te besluiten over te gaan tot emissie van aandelen, tenzij deze bevoegdheid aan een ander orgaan van de vennootschap

173 Op deze plaats zullen slechts enkele, voor mijn verdere betoog noodzakelijke, inleidende opmerkingen worden gemaakt. Zie voor een uitvoerige en gedetailleerde beschrijving van het fenomeen certificering van aandelen F.J.P. van den Ingh, Certificering en certificaat van aandeel bij de besloten vennootschap, diss.

$174 \mathrm{Zie}$ voor een overzicht van de rechten en plichten van de aandeelhouder W.J. Slagter, Compendium, $\S 67$; zie ook $P$. van Schilfgaarde, van de BV en de NV, $10^{\circ}$ druk, nr. 32. Van Schilfgaarde maakt een onderscheid tussen de verschillende functies van het aandeel, de beleggingsfunctie en de zeggenschapsfunctie. 
is gedelegeerd, tot het vaststellen van de jaarrekening en het benoemen, schorsen en ontslaan van bestuurders. ${ }^{175}$ Op de vraag of de individuele aandeelhouder in de praktijk veelvuldig van zijn zeggenschapsrechten gebruik maakt is geen eensluidend antwoord te geven. Bij de beantwoording van deze vraag dient een onderscheid gemaakt te worden tussen de aandeelhouder in een - al dan niet beursgenoteerde - naamloze vennootschap en een aandeelhouder in een besloten familie - vennootschap. De betrokkenheid bij de vennootschap die de aandeelhouder in beide gevallen ten toon spreidt zal vaak verschillend zijn. De houder van aandelen in een grote, beursgenoteerde naamloze vennootschap zal nauwelijks enige vennootschappelijke betrokkenheid voelen. Zijn enige belang bij de vennootschap zal, in veel gevallen, het maximaliseren van de waarde van zijn aandeel zijn. Hij zal er in het algemeen niet over peinzen zijn zeggenschapsrechten binnen de vennootschap aan te wenden, als hij maar kan rekenen op hoge koersen en goede dividenden. De beleggingsfunctie van het aandeel is in dit geval belangrijker dan de zeggenschapsfunctie.

Anders zal het zijn bij een - kleine - besloten vennootschap of bij een besloten naamloze vennootschap, waar bestuur en kapitaal veelal samengaan. Het belang van de - continuïteit van de - vennootschap staat voorop en van een potentiële spanning tussen kapitaal en leiding ${ }^{176}$ is, in tegenstelling tot de situatie bij de open naamloze vennootschap, niet of nauwelijks sprake.

In een situatie waarin de belangen van de aandeelhouders en het bestuur aanmerkelijk van elkaar verschillen is het zeer wel denkbaar dat een toevallige meerderheid die een relatief klein gedeelte van het geplaatst kapitaal vertegenwoordigt, ter vergadering besluiten kan nemen die in het geheel niet in het belang van de vennootschap zijn en de continuïteit van de onderneming zelfs in gevaar kunnen brengen. Het is dan ook gebruikelijk onder deze omstandigheden de bevoegdheden van de algemene vergadering van aandeelhouders statutair te beperken. Zo kan in de statuten worden geregeld dat voor bepaalde besluiten van de algemene vergadering goedkeuring van bijvoorbeeld de vergadering van houders van prioriteitsaandelen vereist is, danwel dat bepaalde besluiten van de algemene vergadering van aandeelhouders slechts op voorstel van de prioriteit kunnen worden genomen. Ook ligt er een bepaalde mate van begrenzing van de macht

175 Dit is anders indien de vennootschap onderworpen is aan het structuurregime. De macht van de aandeelhouder is dan veel beperkter en de belangrijkste bevoegdheden liggen bij de raad van commissarissen; zie de artt. 162/272 BW.

176 Deze spanning tussen leiding en kapitaal kan zich voor doen ten gevolge van de verschillende belangen die door het bestuur en de aandeelhouders worden nagestreefd. "Het belang van de aandeelhouder, die hier (in een zeer grote open $\mathrm{NV} ; \mathrm{JH}$ ) de positie van belegger inneemt, is het maximaliseren van de waarde van de aandelen. Het belang van de bestuurder is een zo hoog mogelijk inkomen bij een sub-maximale inspanning zonder zijn positie op de tocht te zetten. De éen kapitalist, de ander een hebberig lijntrekker dus."; aldus C.A. Schwarz, Aandelen zonder stemrecht, rede 1990 , p. 2. 
van de algemene vergadering besloten in de wet. Zo stelt de wet in bepaalde gevallen quorum eisen, bijvoorbeeld in het tweede lid van art. $133 \mathrm{BW} .^{17}$

Deze statutaire quorum- en goedkeuringseisen zijn natuurlijk niet de enige middelen die - een gedeelte van - de macht van de algemene vergadering van aandeelhouders ${ }^{178}$ bij het bestuur, danwel bij een groep personen die een nauwe en hechte band met het bestuur van de vennootschap onderhouden, kunnen brengen. Certificering van aandelen leidt eveneens tot een verschuiving van machtsverhoudingen.

Het gebruik van certificering in het vennootschapsrecht is afkomstig uit de Verenigde Staten van Amerika. Daar makte men gebruik van een zogenaamde 'voting-trust'. Voogd ${ }^{179}$ schrijft:

"Dit is een consortium waaraan de oorspronkelijke aandelen worden overgedragen en dat daarvoor certificaten uitgeeft. Het doel van de voting-trust was aanvankelijk in hoofdzaak om in het algemeen invloed van buitenaf te weren, doch de voting-trust werd ook wel gebruikt om vreemde invloed uit nationale ondememingen te weren."

De gang van zaken bij certificering van aandelen kan - in het kort - als volgt worden beschreven. De vennootschap - besloten danwel naamloos - plaatst ${ }^{180}$ aandelen bij een, eventueel daartoe opgerichte rechtspersoon, 'stichting admini-

177 De statuten van een vennootschap kunnen bepalen dat de benoeming van bijvoorbeeld een bestuurder kan geschieden uit een bindende voordracht. De algemene vergadering kan aan zo'n voordracht het bindend karakter ontnemen door een besluit dat wordt genomen met twee derden van de uitgebrachte stemmen, die meer dan de helf van het geplaatste kapitaal vertegenwoordigen. Op een algemene vergadering van aandeelhouders waar het opkomstpercentage in het algemeen niet erg hoog ligt, is zo'n quorumeis vaak een afdoende bescherming tegen besluiten van de algemeen vergadering die het belang van de vennootschap zouden kunnen schaden.

178 De wettelijke bevoegdheden blijven natuurlijk toekomen aan de algemene vergadering van aandeelhouders maar door het gebruik van de statutaire quorum- en goedkeuringseisen wordt de vergadering redelijk onmachtig.

179 R.P. Voogd, diss. p. 21. Schrijver geeft an dat voor het laatstgenoemde doel de constructie - in aangepaste vorm - voor het eerst in Nederland is gebruikt. Naderhand is de bescherming, door middel van de certificering, tegen invloed van buiten af een belangrijkere rol gaan spelen. Men bedenke echter dat de regeling ook tegen de achtergrond van het huwelijksvermogensrecht en het. erfrecht een bijzonder belangrijke rol speelt. Zie hier omtrent F.J.P van den Ingh, diss. p. 28 41; schrijver geeft een overzicht van motieven die aan het gebruik van de certificeringsconstructie ten grondslag kunnen liggen. Zie ook S.E. Eisma, Preadvies 1990, p. 59-60.

180 Certificering van aandelen kan op verschillende wijzen tot stand komen. Van den Ingh makt een onderscheid tussen certificering tegen aandelen en certificering tegen contanten. Wordt tegen aandelen gecertificeend dan draagt de aandeelhouder zijn aandelen ten titel van beheer over aan het $\mathrm{AK}$ en het AK geeft vervolgens aan de vervreemder tegen over ieder aandeel eén of meendere certificaten uit. Indien een vennootschap aandelen uitgeeft aan het AK, dat daarvan direct tegen contanten certificaten aan derden uitgeeft, spreekt men van certificering tegen contanten. Zie F.J.P. van den Ingh, diss. p. 16-17. 
stratiekantoor' (AK). Het AK geeft van de in administratie genomen aandelen certificaten uit. De voorwaarden waaronder deze handeling geschiedt vindt men in de administratievoorwaarden die het AK hanteert. Het doel van de certificering van aandelen is het scheiden van de uit het aandeel voortvloeiende vermogensrechten en zeggenschapsrechten. De aandeelhoudersrechten, met name de zeggenschapsrechten, blijven berusten bij de aandeelhouder, het AK. De kapitaalverschaffer/certificaathouder verliest zijn zeggenschap (in het geval hij voorheen aandeelhouder was), danwel verkrijgt geen zeggenschap in de vennootschap wier aandelen gecertificeerd zijn. Men kan dus onderscheiden: de juridisch eigenaar van het vermogen van de vennootschap (het $\mathrm{AK}$ ) en de economisch eigenaar van het vermogen van de vennootschap (de certificaathouder). ${ }^{181}$

Heeft deze scheiding tussen de juridische en economische eigendom van het aandeel ook gevolgen voor de eventuele rechten die aan de certificaathouder toekomen? In beginsel moet men opmerken dat er tussen de certificaathouder en de vennootschap wier aandelen zijn gecertificeerd geen rechtsverhouding bestaat. Van den Ingh merkt op:

"De certificaathouder is immers geen aandeelhouder en staat evenmin in een contractuele relatie tot de vennootschap zoals een schuldeiser. ${ }^{182}$

Toch kent de Nederlandse wet een aantal (aandeelhouders)rechten toe aan de houders van certificaten. Hierbij kan een duidelijk verschil worden gemaakt tussen de rechten die aan iedere certificaathouder toekomen en de rechten die slechts kunnen worden uitgeoefend door houders van bewilligde certificaten. ${ }^{183}$

ledere certificaathouder, ongeacht of er sprake is van medewerking aan de certificering door de vennootschap, heeft het recht tot inzage in de boeken en bescheiden van een ontbonden rechtspersoon. Voor deze inzage dient de certificaathouder toestemming te verkrijgen van de kantonrechter. Deze zal die toestemming slechts verlenen indien de certificaathouder een redelijk belang bij die inzage heeft (art. 24 lid $4 \mathrm{BW}$ ). Aan houders van certificaten komt tevens het recht toe een verzoekschrift tot enquête in te dienen, indien zij ten minste een tiende gedeelte van het geplaatst kapitaal vertegenwoordigen (art. $346 \mathrm{BW}$ ). Op grond van het achtste lid van art. 396 Boek 2 BW heeft de houder van certificaten het recht op inzage in de beperkte balans en toelichting daarop indien de rechtspersoon geen winst beoogt.

Aan houders van met medewerking van de vennootschap uitgegeven aandelen komen, naast de hiervoor genoemde rechten, nog een aantal andere rechten toe.

Men kan stellen dat indien de certificaten met medewerking van de vennootschap zijn uitgegeven aan de certificaathouders de rechten toekomen die ook aan de

183 Zie voor dit verschil $\S$ I.10.3. 
aandeelhouders toekomen, natuurlijk met uitzondering van het stemrecht. De rechten die dan door de houders van bewilligde certificaten kunnen worden uitgeoefend zijn: het recht op inzage in de beschrijving van hetgeen anders dan in geld wordt ingebracht op de aandelen bij de oprichting van de vennootschap (art. 204a lid 1 BW); het recht op inzage en het recht op een kosteloos afschrift van de stukken die worden opgemaakt met betrekking tot het verkrijgen van goedkeuring van de AVA in verband met transacties tussen de vennootschap met een oprichter (art. 94c lid 4 jo 102/204c lid 4 jo 212 BW); het recht op een kosteloos afschrift van het voorstel tot een statutenwijziging (art. 99 lid 8 jo 123 leden 3 en $4 / 208$ lid 5 jo 233 leden 3 en 4 BW); het recht op het inzien en een kosteloos afschrift van de opgemaakte jaarrekening, het jaarverslag en de overige gegevens (art. 102/212 BW); het recht om door de president van de rechtbank te worden gemachtigd de AVA bijeen te roepen (art. 110 lid 2/220 lid 2 en 112/222 BW); het recht te worden opgeroepen voor de AVA door middel van een aankondiging in een landelijk verspreid dagblad, tenzij de statuten de wijze van oproeping voor de AVA op een andere wijze regelen (art. 113 lid 1/223 lid 2 BW); het recht om ter kantore van de vennootschap kennis te nemen van de ter AVA te behandelen onderwerpen voorzover deze niet in de oproeping tot de AVA zijn bekend gemaakt (art. 114 lid 1/224 lid 1 BW); het recht om de AVA bij te wonen en aldaar het woord te voeren (art. 117 lid $2 / 227$ lid 2 BW); het recht op een kosteloos afschrift van voorstellen tot vermindering van het geplaatst kapitaal (art. 208 lid 5 jo lid $3 / 233$ lid 4 jo lid 3 BW) en het recht op inzage in en een kosteloos afschrift van stukken die in verband met een juridische fusie ten kantore van de vennootschap zijn neergelegd (art. 329 jo 314 lid 2 BW). ${ }^{184}$

Uit het bovenstaande moge duidelijk worden dat de rechten van de houders van bewilligde certificaten omvangrijker zijn dan die welke toekomen aan de houders van onbewilligde certificaten. In de volgende paragraaf zal worden besproken in welke gevallen we spreken van al dan niet bewilligde certificaten. Vervolgens zal bezien worden of de vestiging van een pandrecht op de aandelen die het AK houdt gevolgen sorteert voor de rechten van de houders bewilligde en niet bewilligde certificaten.

\section{I.10.3 Bewilligd versus niet-bewilligd certificaat; medewerking}

Of een certificaathouder bepaalde rechten geldend kan maken jegens de vennootschap die haar aandelen gecertificeerd heeft, is afhankelijk van de vraag of de

184 Zie ook F.J.P. van den Ingh, diss. p. 245-247; mijns inziens verzuimt Van den Ingh art. 8 BW te noemen bij de rechten van de houders van met medewerking van de vennootschap uitgegeven certificaten. Over het belang van art. 8 jo $15 \mathrm{BW}$ meer in $\$ 1.10 .5$; zie ook S.E. Eisma, Preadvies 1990, p. 89. 
certificaten een bewilligd danwel een niet-bewilligd karakter hebben. Het criterium aan de hand waarvan bepaald wordt of de certificaten bewilligd zijn of niet, is gelegen in het feit of de vennootschap, wiens aandelen gecertificeerd zijn, medewerking aan de certificering heeft verleend. Wanneer kan men nu spreken over medewerking van de vennootschap aan de certificering van haar aandelen? Dat deze vraag van eminent belang is moge duidelijk zijn.

Niet alleen het ontstaan van een aantal aandeelhoudersrechten voor certificaathouders valt of staat bij de aanwezigheid van medewerking der vennootschap, ook het ontstaan van het wettelijk pandrecht ${ }^{185}$ is, in beginsel, afhankelijk van de vraag of er wel of geen medewerking is verleend aan de certificering.

Gelijk Van den Ingh ${ }^{186}$ wordt ook door Schwarz ${ }^{187}$ betoogd dat de vraag naar de al dan niet aanwezige medewerking der vennootschap vrijwel alleen zal spelen bij de constructie waarbij tegen aandelen wordt gecertificeerd.

Ten aanzien van de vraag wanneer sprake is van 'medewerking der vennootschap', indien tegen aandelen wordt gecertificeerd, liepen de meningen in de literatuur uiteen. Men treft zowel de opvatting aan dat de geringste betrokkenheid van de vennootschap bij de certificering van haar aandelen medewerking impliceert, als de mening dat de vennootschap uitdrukkelijk haar wens tot certificering naar buiten toe dient uit te spreken en zich ook daadwerkelijk met de certificeringshandeling dient te bemoeien alvorens men tot medewerking kan concluderen. ${ }^{188} \mathrm{Ik}$ zal kort ingaan op deze beide zienswijzen en aansluitend komen tot een omschrijving van het begrip 'medewerking' zoals dat naar de heersende leer dient te worden ingevuld.

Door Schwarz ${ }^{189}$ wordt betoogd dat men vanuit twee verschillende invalshoeken kan komen tot invulling van het begrip medewerking. Hij stelt:

"In de eerste plaats is er de benadering vanuit de zienswijze waarin de belangen van de vennootschap voorop staan. Deze visie leidt ertoe dat, vooral bij de b.v., waar de beslotenheid van het samenwerkingsverband wettelijk verplicht is voorgeschreven, het medewerkingscriterium, beperkt wordt uitgelegd.

185 Hierover meer in $\S 1.10 .4$.

186 F.J.P. van den Ingh, diss. p. 87. Schrijver betoogt het volgende: "Bij de beantwoording van de vraag of de vennootschap aan de uitgifte van certificaten heeft medegewerkt, behoeft geen twijfel te bestaan in het geval er sprake is geweest van certificering tegen contanten. In dat geval heeft de vennootschap rechtstreeks aandelen uitgegeven aan een $\mathrm{AK}$, zodat gezegd kan worden dat het initiatief tot certificering van de vennootschap is uitgegaan. En waar het initiatief is uitgegaan van de vennootschap, mag haar medewerking worden verondersteld, (...)."

187 C.A. Schwar, TVVS 1992, p. 7.

188 Zie F.J.P. van den Ingh, diss. p. 85 e.v.; zie ook C.A. Schwar, TVVS 1992, p. 8.

189 C.A. Schwar, TVVS 1992, p. 7. 
In de tweede plaats is er een invulling van het medewerkingscriterium mogelijk vanuit de gedachte dat de positie van de certificaathouder jegens de vennoctschap krachtig wordt versterkt bij medewerking van de vennootschap aan de certificering. Vanuit dit perspectief wordt het medewerkingscriterium zeer ruim geïnterpreteend."

Na een korte historische beschouwing ${ }^{190}$ aangaande de - wijziging van de rechtspositie van de certificaathouder binnen de vennootschap komt Schwarz tot de conclusie dat:

"(...) bij de beantwoording van de vraag of medewerking is verleend, de ratio van de regeling (totstandkoming van de Structuurwet; JH), die was versterking van de positie van de certificaathouders, bepalend is. Ik meen derhalve dat het medewerkingscriterium zeer ruim uitgelegd dient te worden. ${ }^{n 191}$

Van den Ingh heeft duidelijk een andere visie. Hij is van mening dat de rechtszekerheid niet gediend is bij een ruime uitleg van het medewerkingscriterium. Het komt hem onwenselijk voor dat iedere - zelfs de geringste - vorm van betrokkenheid van de vennootschap bij de certificering van haar aandelen de consequentie heeft dat de certificaathouder lidmaatschapsrechten kan doen gelden jegens de vennootschap. Hij pleit dan ook voor een wettelijke regeling waarin wordt bepaald dat de medewerking van de vennootschap moet blijken uit een daartoe strekkend besluit van de vennootschap. ${ }^{192}$ Schwarz neemt krachtig stelling tegen deze visie van Van den Ingh. Hij schrijft:

\begin{abstract}
"Van den Ingh beziet de medewerkingsproblematiek vanuit het vennootschappelijk perspectief. Deze oplossing van het probleem lijkt mij niet bevredigend omdat een formeel besluit de doorslag zou gaan geven, terwijl de facto de certificeringsoperatie geheel door de vennootschap kan zijn geregisseerd en bekostigd. (...) Het lijkt mij onjuist dat een vennootschap, die uitdrukkelijk het initiatief tot certificering neemt, door een verklaring dat geen medewerking wordt verleend, het ontstaan van lidmaatschapsrechten kan voorkomen. ${ }^{n 193}$
\end{abstract}

Van den Ingh keert zich tegen het standpunt van Schwarz. Hij overweegt:

"Ik meen dat men onderscheid zou moeten (kunnen) maken tussen medewerking in feitelijke zin en het begrip 'medewerking' in de zin van Boek 2 BW, (...). De kemvraag in dit verband lijkt mij te zijn of personen die een certificaat kopen reden hebben zich bekocht te voelen. Daarbij moet in aanmerking worden genomen dat cerrificaathouders dikwijls niet op

190 Schwar verwijst naar het rapport van de Commissie Verdam, Herziening van het Ondernemingsrecht, 's-Gravenghage, 1965.

191 C.A. Schwar, TVVS 1992, p. 7.

192 F.J.P. van den Ingh, diss. p. 89 en TVVS 1992, p. 77. Zie voor de vraag welk orgaan van de vennootschap bevoegd is te besluiten medewerking te verlenen aan de certificering van haar aandelen, F.J.P. van den Ingh, diss. p. 90-91.

193 C.A. Schwar, TVVS 1992, p. 7-8. 
de hoogte zullen zijn van de aan- of afwezigheid van feitelijke betrokkenheid van de vennootschap. $\mathrm{Zij}$ zien alleen een slotverklaring in de administratievoorwaarden die duidelijkheid biedt. ${ }^{\text {n19 }}$

Hoe nu te oordelen ten aanzien van de invulling van het begrip 'medewerking der vennootschap'. Maeijer ${ }^{195}$ geeft de volgende beschouwing:

"In de wetsgeschiedenis lezen wij dat dit in de regel kan worden afgeleid uit het feit dat de kosten van certificering te haren laste komen; ook kan medewerking in de administratievoorwaarden zijn vermeld, of kan blijken dat de vennootschap het initiatief tot certificering heeft genomen; bij stukken die (op verzoek van de vennootschap) ter beurze worden genoteerd, kan men erop rekenen dat zij met medewerking van de vennootschap zijn uitgegeven. (...)

Voor medewerking is voldoende dat uitdrukkelijk of stilzwijgend blijkt van het (willen) bevorderen van de certificering (...). Iets te ver gaat mijns inziens LUBBERS, Bewind in het NBW (1983), p. 104, die 'medewerken' gelijk stelt met instemmen. Zo is het enkel verlenen van goedkeuring door een vennootschappelijk orgaan in het kader van een blokkeringsregeling voor de overdracht van aandelen aan het AK, nog geen 'medewerking', en evenmin het erkennen door de vennootschap van de levering.(...). Wel kan als medewerking worden opgevat dat bestuurders of commissarissen als zodanig lid van het bestuur zijn van het AK of dat een vennootschappelijk orgaan dergelijke bestuursleden benoemd. (...) Ook bij rechtstreekse uitgifte door de vennootschap van aandelen aan het AK zal van medewerking sprake zijn. (...)

Een (expliciet of formeel) besluit van een vennootschappelijk orgaan om medewerking te verlenen, is niet nodig. De medewerking kan ook worden afgeleid uit feitelijke omstandigheden of gebeurtenissen; (...)."

In de elfde druk van het Handboek lezen wij nog:

"De term 'medewerking' is vrij vaag. Medewerking is in ieder geval aanwezig, indien het initiatief tot de certificering is uitgegaan van de vennootschap (curs;JH). (...) Voor medewerking van de vennootschap is naar onze mening behoudens afwijkende statutaire voorziening nodig een besluit van de algemene vergadering; de medewerking behoort niet tot het besturen van de vennootschap. ${ }^{1 \% 6}$

Van der Grinten blijft de term 'medewerking' vaag vinden, maar hij verdedigt in de twaalfde druk van zijn Handboek:

"Wij zouden willen aannemen dat onder medewerking moet worden verstaan, dat de vennootschap op enigerlei wijze betrokken is bij de uitgifte van de certificaten. De vennootschap werkt mede aan de uitgifte indien zij heeft bevorderd dat aandelen aan het administratiekantoor worden overgedragen, indien zij de kosten van de certificering voor haar rekening neemt. Van medewerking van de vennootschap kan o.i. ook worden

194 F.J.P. van den Ingh, TVVS 1992, p. 77.

195 Asser-Maeijer-2-III, nr. 409.

196 Handboek (1989), nr. 197. 
gesproken, indien bestuurders of commissarissen van de vennootschap deel uimaken van het bestuur van het administratiekantoor. ${ }^{\text {"197 }}$

Duidelijk wordt dat Van der Grintens opvatting ten aanzien van het begrip medewerking aanzienlijk ruimer is geworden. Een formeel besluit van een vennootschapsorgaan is niet langer nodig om van medewerking der vennootschap aan de uitgifte van certificaten van aandelen te spreken. Van medewerking is reeds sprake indien de vennootschap op enigerlei wijze bij de certificering betrokken is. ${ }^{198}$

Men het oog op de huidige rechtsopvatting ten aanzien van het begrip 'medewerking' ben ik van mening dat de eerder besproken visie van Schwarz dan ook de juiste is. Mede gezien tegen de achtergrond van de wetshistorie dient geconcludeerd te worden dat de term 'medewerking' ruim uitgelegd dient te worden. Hierdoor wordt de positie van de certificaathouders aanzienlijk versterkt.

In de volgende paragraaf zal nader worden ingegaan op de gevolgen van het al dan niet aanwezig zijn van medewerking der vennootschap aan de certificering van aandelen in haar kapitaal. Met name zal worden ingegaan op het ontstaan van het wettelijk pandrecht van art. 3:259 BW ten behoeve van de certificaathouders.

\section{I.10.4 Wettelijk pandrecht; vestiging van een 'gewoon' pandrecht; gevolgen}

In de vorige paragraaf werd reeds opgemerkt dat het ontstaan van het wettelijk pandrecht ten behoeve van certificaathouders afhankelijk is van de vraag of de vennootschap medewerking heeft verleend aan de uitgifte van de certificaten. Het (ontstaan van dit) wettelijk pandrecht zal hierna worden geanalyseerd.

Een bepaling betreffende het wettelijk pandrecht van certificaathouders kwam reeds voor in het Ontwerp Meijers. ${ }^{199}$ Art. 3.6.2.7. was, als slotartikel, opge-

197 Handboek (1992), nr. 197.

198 Zie ook $L$. Timmerman, Bespreking van de twaalfde druk van het Handboek voor de naamloze en de besloten vennootschap, bewerkt door Prof. mr W.C.L. van der Grinten, NV 72 (1994), p. 250. Timmerman acht het door Van der Grinten ingenomen standpunt ten aanzien van de invulling van het begrip medewerking "soepeler en (...) daarom juister".

199 Ar. 3.6.2.7. E.M. Meijers, Ontwerp voor een Nieuw Burgerlijk Wetboek, Tekst Eerste Gedeelte 1-4. Staatsdrukkerij en uitgeverijbedrijf/'s-Gravenhage, 1954, p. 133. Art. 7: Wanneer iemand door het uitgeven van certificaten derden doet delen in de opbrengst van aandelen of schuldvorderingen, die door hem op eigen naam zijn verkregen, ontstaat daardoor geen bewind, maar hebben de certificaathouders een vordering tot uitkering van het hun toegezegde tegen de uitgever der cerrificaten, benevens, indien de nodige kennisgevingen zijn gedaan, gezamenlijk een pandrecht op de oorspronkelijke aandelen of schuldvorderingen. Dit pandrecht geeft aan de 
nomen in de afdeling houdende bijzondere bepalingen voor het bij rechtshandeling ingestelde bewind. Dit ondanks het feit dat in het artikel vermeld wordt dat certificering geen vorm van bewind is. ${ }^{200}$ De reden dat het artikel daar geplaatst werd en niet bij de bepalingen inzake pandrecht kan, volgens Van den Ingh ${ }^{201}$, geen andere zijn dan dat in het artikel gesproken wordt van een bewindvoerder. Tijdens de behandeling van de Invoeringswet Boek 3 NBW werd aanvankelijk besloten de invoering van titel 6 uit te stellen. Het artikel keerde echter, op aandrang van het Genootschap voor Bedrijfsjuristen, weer terug. Het artikel werd uit titel 6 genomen en ingevoegd na afdeling 2 van titel 9 Boek 3. Opgenomen werd een derde afdeling, Pandrecht van certificaathouders, houdende één artikel; art. 3:259 BW. ${ }^{202}$

\section{Art. 3:259 BW}

lid 1. Wanneer iemand door het uitgeven van certificaten derden doet delen in de opbrengst van door hem op eigen naam verkregen aandelen of schuldvorderingen, bebben certificaathouders een vordering tot uitkering van het hun toegezegde tegen de uitgever van de certificaten.

lid 2. Zijn de oorspronkelijke aandelen of schuldvorderingen op naam gesteld en de certificaten uitgegeven met medewerking van de uitgever van de oorspronkelijke aandelen of schuldvorderingen, dan verkrijgen de certificaathouders tevens gezamenlijk een pandrecht op die aandelen of schuldvorderingen. Zijn de certificaten uitgegeven voor schuldvorderingen op naam zonder medewerking van de schuldenaar, dan verkrijgen de certificaathouders een zodanig pandrecht door mededeling van de uitgifte aan de schuldenaar. Zijn de certificaten uitgegeven voor aandelen of schuldvorderingen aan toonder, dan verkrijgen de certificaathouders een zodanig pandrecht, zonder dat het papier in de macht van de certificaathouders of een derde behoeft te worden gebracht.

lid 3. Dit pandrecht geeft aan de certificaathouders alleen de bevoegdheid ingeval van nietuitbetaling van het hun verschuldigde met inachtneming van de volgende regels het pand geheel of gedeeltelijk te doen verkopen en zich uit de opbrengst te voldoen. Een certificaathouder die hiertoe wenst over te gaan, wendt zich tot de president van de rechtbank van de woonplaats van degene die de certificaten heeft uitgegeven met verzoek een bewindvoerder over het pand te benoemen, die voor de verkoop en de verdeling van de opbrengst zorg draagt. Indien niet alle certificaathouders met de verkoop instemmen, wordt slechis een deel van het pand dat overeenkomt met het recht van de andere certificaathouders verkocht; de rechten van deze laatsten gaan door verdeling van de opbrengst onder hen teniet. De president kan op verlangen van elke certificaathouder of ambtshalve maatregelen bevelen in

\section{$199 \rightarrow$}

certificaathouders alleen de bevoegdheid, om in geval van niet-uitbetaling van het hun verschuldigde, het pand te verkopen en zich uit de opbrengst te voldoen.

200 Zie over de vraag of van een bewind in eigenlijke zin sprake is F.J.P. van den Ingh, diss. p. 187. De zin "door uitgifte van certificaten (...) ontstaat geen bewind" in art. 3.6.2.7. is komen te vervallen, zie Van Zeben, Du Pon (II), p. 1348.

201 F.J.P. van den Ingh, diss. p. 181.

202 Van Zeben, Du Pon (II), p. 1201 en 1348. 
het belang van de certificaathouders die niet met de verkoop hebben ingestemd, en bepalen dat de verkoop door hem moet worden goedgekeurd, wil zij geldig zijn.

Bezien wij het tweede lid van art. 259 Boek 3 BW dan blijkt dat er drie soorten pandrecht ten behoeve van certificaathouders kunnen ontstaan.

a. Een pandrecht ten behoeve van de houders van certificaten, waarbij de oorspronkelijke aandelen of schuldvorderingen op naam zijn gesteld en de certificaten zijn uitgegeven met medewerking van de uitgever van de oorspronkelijke aandelen of schuldvorderingen;

b. een pandrecht ten behoeve van certificaathouders waarbij de certificaten van de oorspronkelijke schuldvorderingen op naam zonder medewerking van de schuldenaar ${ }^{203}$ zijn uitgegeven en

c. een pandrecht ten behoeve van certificaathouders waarbij certificaten zijn uitgegeven voor aandelen of schuldvorderingen aan toonder.

Het eerste pandrecht (onder a.) dat door de certificaathouders wordt verkregen, ontstaat van rechtswege ten tijde van de uitgifte van de certificaten indien vaststaat dat de certificaten zijn uitgegeven met medewerking van de schuldenaar. Het pandrecht komt de certificaathouders gezamenlijk toe. De aandelen of schuldvorderingen bevinden zich in een gemeenschap waarvan de gezamenlijke certificaathouders de gerechtigden zijn. ${ }^{204}$

Het pandrecht onder b. ontstaat niet van rechtswege. De certificering heeft immers niet met medewerking van de schuldenaar plaatsgevonden. De certificaathouders verkrijgen het pandrecht niet dan nadat mededeling van de certificering is gedaan aan de schuldenaar. In dit tweede geval spreekt de wet slechts van schuldvorderingen en niet van aandelen. Mijns inziens kan men hieraan de conclusie verbinden dat geen pandrecht, als bedoeld in dit artikel, kan ontstaan ten behoeve van de houders van onbewilligde certificaten van aandelen op naam. Men zal in deze situatie steeds terug moeten vallen op de algemene regels betreffende het vestigen van een 'gewoon' pandrecht. ${ }^{205}$ De ratio van deze regeling lijkt dus te zijn dat - in beginsel - geen lidmaatschapsrechten moeten kunnen ontstaan bij niet bewilligde certificaten.

203 Dit is de vennootschap, de uitgever van de oorspronkelijke aandelen of schuldvorderingen.

204 F. Molenaar, Pandrecht, Mon. Nieuw BW, B12a, $2^{\circ}$ druk 1991, p. 59. Zie ook F.J.P. van den Ingh, diss. p. 183.

205 Zie ook C.AE. Uniken Venema, Preadvies 1990, p. 280-281; over art. 3:259 (3.9.3.1. NBW) W. Snijders, in: Verslag Preadvies Ver. Handelsr. 1990, p. 35: "Over het artikel zelf wil ik twee opmerkingen maken. In de eerste plaats de vraag voor welke objecten het geldt, met name voor zover het om aandelen gaat. Inderdaad geldt het alleen voor certificaten voor aandelen op naam wanneer deze met medewerking van de uitgever van de oorspronkelijke aandelen uitgegeven zijn. Zonder een dergelijke medewerking kan dus het vereenvoudigd pandrecht niet van rechtswege ontstaan." Zie ook Van Zeben, Du Pon (I), p. 570. 
De vraag of in het derde geval, dat in het tweede lid van art. 259 Boek 3 BW wordt genoemd, pandrecht van rechtswege ontstaat is in de literatuur omstreden. Volgens Molenaar ${ }^{206}$ ontstaat het pandrecht in geval van certificaten, uitgegeven voor aandelen of schuldvorderingen aan toonder, van rechtswege. Met de uitgifte van de certificaten van aandelen of schuldvorderingen aan toonder verkrijgen de certificaathouders een stil pandrecht, het papier hoeft immers niet in de macht van de certificaathouder of een derde te worden gebracht, op de toonderstukken. De vraag of de certificaten al dan niet met medewerking van de vennootschap zijn uitgegeven, lijkt in de visie van de wetgever hier geen rol te spelen.

Uniken Venema is daarentegen van mening dat het pandrecht niet van rechtswege ontstaat. Hij stelt:

"Met betrekking tot certificeringen van aandelen of schuldvorderingen aan toonder ontstaat
niet van rechtswege een vereenvoudigd pandrecht - zoals in bepaalde hierboven aangeduide
gevallen wél ontstaat met betrekking tot aandelen op naam. Een pandrecht ontstaat derhalve
met betrekking tot gecertificeerde aandelen of schuldvorderingen aan toonder uitsluitend
indien door partijen in het kader van de certificering of op een later tijdstip door middel van
een daartoe strekkende rechtshandeling een pandrecht wordt gevestigd." ${ }^{207}$

In de visie van Uniken Venema ontstaat slechts een gezamenlijk pandrecht met betrekking tot aandelen en schuldvorderingen aan toonder indien dit door de certificaathouders en het administratiekantoor wordt overeengekomen.

Van den Ingh komt in tegenstelling tot Uniken Venema tot de, mijns inziens juiste, slotsom dat in geval van certificering van aandelen en schuldvorderingen aan toonder "zonder meer een pandrecht is gegeven". 2008

Een met dit punt samenhangende vraag is waarom het begrip 'medewerking' in het tweede lid van art. 259 Boek $3 \mathrm{BW}$ is opgenomen.

In de $\mathrm{NvW}$ wordt de eindtekst van lid 2 van art. 3.6.2.7. (3:259 $\mathrm{BW}$ ) als volgt toegelicht:

"In de praktijk komt uitgifte van certificaten slechts voor, indien de aandelen op naam zijn gesteld. Opnaamstelling van de aandelen pleegt te geschieden om de kring der aandeelhouders besloten te houden. Deze beslotenheid zou worden doorbroken, indien de aandeelhouder buiten de vennootschap om door de uitgifte van certificaten derde bevoegdheden in de vennootschap zou kunnen verschaffen. Door in de genoemde artikelen deze bevoegdheden slechts toe te kennen aan houders van certificaten die met medewerking der vennootschap zijn uitgegeven, heeft de wetgever dit voorkomen. (...) het ligt in de lijn van de genoemde bepalingen van Boek 2 ook het wettelijk pandrecht dat in lid 2 van het onderhavige artikel aan houders van certificaten wordt toegekend, voor zover dit certificaten van aandelen

206 F. Molenaar, Pandrecht, Mon. Nieuw BW, B12a, $2^{\mathrm{c}}$ druk, Kluwer 1991, p. 59-60.

207 C.A. Uniken Venema, Preadvies 1990, p. 281.

208 Zie Van den Inghs argumenten in Verslag Preadvies Ver. Handelsr. 1990, p. 15. Zie ook C.A. Schwar. Enkele vragen bij certificering van aandelen, TVVS 1992 p. 7 (en noot 5). 
betreft, alleen te verlenen indien de uitgifte daarvan met medewerking van de vennootschap heeft plaatsgevonden. Immers, ook door executie van de verpande aandelen kan de beslotenheid van de aandeelhouderskring worden doorbroken en het gaat niet aan dat een aandeelhouder de vennootschap dit risico buiten haar medewerking om laat lopen. "2009

Het argument dat door de wetgever voor het opnemen van het medewerkingscriterium wordt gebruikt komt neer op het waarborgen van de beslotenheid van het samenwerkingsverband. Het besloten karakter van de vennootschap moet dus niet doorbroken kunnen worden, ten gevolge van het ontstaan van een wettelijk pandrecht ten behoeve van certificaathouders, indien de certificaten zonder medewerking van de vennootschap zijn uitgegeven.

Een ander punt is het volgende. Art. 3:259 BW heeft geen dwingend rechtelijk karakter. ${ }^{210}$ In de statuten van de vennootschap kan het ontstaan van het wettelijk pandrecht, op de aandelen die door het AK gehouden worden, uitgesloten worden. Ook in de administratievoorwaarden kunnen partijen (AK en certificaathouders) overeenkomen dat het wettelijk pandrecht niet ontstaat. ${ }^{211}$ Maeijer $^{212}$ merkt nog op dat het niet snel tot toepassing van art. 3:259 BW zal komen:

"Het belang van het artikel is veeleer daarin gelegen dat het derden zal afhouden van het nemen van verhaal op de aandelen waarvoor de certificaten zijn afgegeven. (...) Van verschillende zijden is opgemerkt dat het geenszins voor de hand ligt dat certificaathouders door dit pandrecht voorrang krijgen bij hun verhaal boven de zaakschuldeisers van het AK, die een vordering hebben gekregen omdat het AK met hen heeft gecontracteerd bij de vervulling van zijn beheerstak."

Het wettelijk pandrecht ten behoeve van houders van certificaten kan dus worden uitgesloten. Ook indien de certificaten met medewerking van de vennootschap zijn uitgegeven kan dit het geval zijn.

In deze situatie kan er wel een 'gewoon' pandrecht, ten behoeve van de certificaathouders op die aandelen, worden gevestigd, tenzij de statuten van de vennoot-

209 Van Zeben, Du Pon (I), p. 570.

210 Zie Asser-Maeijer-2-II, nr.408. Zie ook W. Snijders, in: Verslag Preadvies Ver. Handelsr. 1990 , p. 35-36. Snijders merkt ten aanzien van het wettelijk pandrecht op: "Het (artikel;JH) geeft wel een pandrecht dat er een beetje uitziet dat het van rechtswege wordt gevestigd (...), maar het is in wezen een vereenvoudigd pandrecht en ik zou het ook helemaal niet uitgesloten achten dat men $z 0^{\prime}$ n pandrecht van rechtswege niet wil en de voorkeur geeft aan een gewoon conventioneel pandrecht omdat men dan precies kan regelen wat men wil en wat men met dat pandrecht wil bereiken."

211 Asser-Maeijer-2-III, nr. 408.

212 Asser-Maeijer-2-III, nr. 408. 
schap anders bepalen. ${ }^{213}$ Voorts kan in de doelomschrijving van de stichting AK worden bepaald dat het AK de door haar gehouden aandelen niet mag verpanden. $^{214}$

Een pandrecht kan slechts dan gevestigd worden indien er een vordering is waarvoor wordt verpand. Met andere woorden: pandrecht veronderstelt een vordering. Men kan zich nu afvragen waaruit die vordering bestaat in de relatie AK - certificaathouder. Mijns inziens vloeit zij voort uit het vorderingsrecht dat de certificaathouder jegens het AK heeft. Dit vorderingsrecht kan op zijn beurt rechtstreeks worden afgeleid uit de bepalingen van de certificeringsovereenkomst, zoals neergelegd in de administratievoorwaarden waaronder de certificering is aangegaan. De administratievoorwaarden vormen de inhoud van de overeenkomst - wederkerig van aard - tussen het AK en de certificaathouder. ${ }^{215}$

In deze administratievoorwaarden wordt veelal bepaald dat het $\mathrm{AK}$ alle aan de geadministreerde aandelen verbonden rechten uitoefent, en voorts alle dividenden int en andere uitkeringen op de aandelen ontvangt. Het $\mathrm{AK}$ heeft evenwel de plicht het ontvangen dividend en alle andere uitkeringen (of een bedrag gelijk aan de waarde van het ontvangen dividend en de ontvangen uitkeringen) binnen een nader te bepalen termijn beschikbaar te stellen aan de certificaathouders. Immers - de waarde van - alle uitkeringen die het AK op de aandelen ontvangt, zijn bestemd voor de certificaathouders. ${ }^{216}$ De certificaathouders zijn de economische eigenaren van het kapitaal van de vennootschap en zijn dus gerechtigd dividenden en andere uitkeringen te claimen.

De houder van certificaten die zonder medewerking van de vennootschap zijn uitgegeven verkrijgt eerder genoemde - aandeelhouders - rechten niet van rechtswege wanneer een 'gewoon' pandrecht te zijner gunste wordt gevestigd. De statuten van de vennootschap dienen de weg hiertoe open te stellen en bij

213 Het vestigen van een 'vrij' pandrecht kan verbetering brengen in deze situatie. Niet alleen de positie van de houder van een niet-bewilligd certificaat, maar ook de positie van de houder van met medewerking uitgegeven certificaten, waarbij echter het ontstaan van het wettelijk pandrecht van art. 3:259 BW werd uitgesloten, wordt sterker.

214 M.i. kan ook in de beschrijving van de contractuele relatie tussen de certificaathouder en het AK - de administratievoorwaarden - worden bepaald dat het AK geen (gewoon) pandrecht op de gecertificeerde aandelen mag vestigen. Op de vraag boe deze bepaling zich verhoudt met het ontstaan van een wettelijk pandrecht ten behoeve van de houders van met medewerking der vennootschap uitgegeven cerrificaten zal nader worden ingegaan.

215 Zie voor het karakter en de aard van de administratievoorwaarden F.J.P. van den Ingh, diss. p. 154 e.v.

216 In gelijke zin F.J.P. van den Ingh, diss. p. 157 en 171-173. Opmerking verdient het feit dat indien de vennootschap in plaats van dividenden, bonusaandelen aan het AK uitkeert deze bonusaandelen in eigendom ten titel van beheer van het AK geraken en dat het AK van deze aandelen vervolgens certificaten uitgeeft. 
vestiging en/of overgang van het pandrecht mag niet anders zijn bepaald. ${ }^{217} \mathrm{De}$ ratio van deze bepaling is ook hier dat het besloten karakter van het samenwerkingsverband gewaarborgd dient te worden.

Reeds werd opgemerkt dat, ook al doet de redactie van de bepaling het tegendeel vermoeden, art. 3:259 BW geen dwingend recht bevat. Dit betekent dat het wettelijk pandrecht van rechtswege kan ontstaan. Kan omdat het ontstaan van het wettelijk pandrecht uitgesloten kan worden. Is dit het geval dan ontstaat het pandrecht niet, ongeacht of de certificaten met medewerking der vennootschap zijn uitgegeven. Door Snijders ${ }^{218}$ werd al aangegeven dat partijen de voorkeur kunnen geven aan een conventioneel pandrecht in plaats van een door de wetgever gedicteerd pandrecht. ${ }^{219}$

In de verhouding AK - houder van een bewilligd certificaat kan dus een 'gewoon' pandrecht ontstaan, conform de eisen die gelden voor de vestiging van zulk een pandrecht. Zo'n pandrecht kan ook worden gevestigd ter versterking van de positie van de houder van een niet met medewerking der vennootschap uitgegeven certificaat. Daarnaast is zo'n pandrecht denkbaar naast het wettelijk pandrecht, mits het ontstaan van dit 'gewone' pandrecht niet is uitgesloten. Mijns inziens neemt dit vrij gevestigde 'gewone' pandrecht rang na het wettelijk pandrecht ten behoeve van de gezamenlijke certificaathouders. Tenslotte kan zo'n 'gewoon' pandrecht ook gevestigd worden ten behoeve van een derde. Men denke hierbij aan een kredietinstelling die aan het AK een lening heeft verstrekt. In dit laatste geval gaat het vrij gevestigde pandrecht uiteraard in rang boven het wettelijke pandrecht. Immers, het wettelijke pandrecht komt eerst bij de certificering tot stand.

Alvorens nu in te gaan op de vraag onder welke omstandigheden certificaathouders hun pandrecht kunnen uitoefenen en de procedure die daarbij dient te worden gevolgd, zal aandacht worden besteed aan het ontstaan van 'lidmaatschapsrechten' in de verhouding certificaathouder-vennootschap.

217 Zie art. 89/198 lid 4 BW, nweede volzin.

218 W. Snijders, in: Verslag Preadvies Ver. Handelsr. 1990, p. 35-36.

219 Als voordeel van het wettelijke pandrecht kan genoemd worden dat dit, mits niet uitgesloten, van rechtswege ontstaat. Partijen hoeven dus niets nader overeen te komen. Het voordeel van een vrij gevestigd 'gewoon' pandrecht is dat partijen in de akte van verpanding bedingen kunnen op nemen die toegespitst zijn op hun rechtsverhouding. Partijen kunnen bijvoorbeeld afspraken maken omtrent executie van het pandrecht (zie ar. 3:251 lid 1 BW), terwijl executie van het wettelijke pand dient te geschieden conform het bepaalde in art. 3:259 lid $3 \mathrm{BW}$. 


\section{I.10.5 Lidmaatschapsrechten; organisatorische betrokkenheid}

Op dit punt aanbeland stel ik opnieuw de vraag aan de orde naar de kwalificatie van de verhouding tussen de certificaathouder/pandhouder en de vennootschap. In $\S$ I.10.2. werd opgemerkt dat er in beginsel geen sprake is van een rechtsverhouding tussen de vennootschap en de certificaathouder. Toch kent de Nederlandse wet bepaalde rechten toe aan houders van certificaten die deze geldend kunnen maken ten opzichte van de vennootschap. Kan men nu op basis van dit enkele gegeven spreken van een lidmaatschapsverhouding tussen certificaathouder en vennootschap? Zijn het lidmaatschapsrechten die de certificaathouder jegens de vennootschap geldend kan maken ingeval hij een bewilligd certificaat houdt? ${ }^{220}$ Naast deze vragen zal in de navolgende beschouwing ook de betekenis van het (wettelijk) pandrecht, rustend op de gecertificeerde aandelen, die gehouden worden door het administratiekantoor, voor het ontstaan van de lidmaatschapsverhouding worden besproken. In deze paragraaf zal worden uitgegaan van de certificering van aandelen op naam.

Van der Grinten stelt dat de wet een rechtsverhouding schept tussen de vennootschap en de houder van een met medewerking der vennootschap uitgegeven certificaat. Hij werkt deze stelling uit door op te merken dat de houder van een bewilligd certificaat bepaalde 'aandeelhoudersrechten' tegenover de vennootschap heeft. ${ }^{221}$ Eisma $^{222}$ is van mening dat:

"Door deze medewerking (van de vennootschap aan de certificering; $\mathrm{JH}$ ) ontstaat een rechtstreekse band tussen de certificaathouder en de vennootschap, die tot uitdrukking komt in de toekenning van bepaalde, niet onbelangrijke rechten aan de certificaathouder. Hen worden door de wet lidmaatschapsrechten toegekend. Een dergelijke band en de toekenning van die lidmaatschapsrechten rechtvaardigt dat die certificaathouder niet alleen de lusten,

220 Algemeen aanvaand is de stelling dat de verhouding aandeelhouder - vennootschap dient te worden gekwalificeerd als een lidmaatschapsvertouding (zie 0.a. Handboek (1992), nr. 131; $P$. van Schilfgaarde, Van de BV en de NV, $10^{\circ}$ druk, nrs. 1 en 32 en C.A. Schwarz, diss. p. 74). Van Mourik over het wezen van het aandeel en het aandeelhouderschap: "Mij dunkt dat wij daarbij primair dienen te denken aan deelneming in het geplaatste kapitaal van de vennootschap. Deze levert voor de deelnemer een bijzonder vorderingsrecht op. Het bijzondere is gelegen in de niet-opeisbaarheid en in het feit dat aan het vorderingsrecht zeggensmacht binnen de organisatie is verbonden. Aldus bezien vloeit de zeggensmacht voort uit de deelneming in het kapitaal. Door deel te nemen in het kapitaal treedt men toe tot de vennootschap. Tussen vennootschap en deelnemer bestaat een lidmaatschapsverhouding. Deze wordt aangeduid met de term "aandeelhouderschap'. Met het aandeelhouderschap is de zeggensmacht noodzakelijk gegeven." (zie M.J.A. van Mourik, NV 62 (1984), p. 200). De lidmaatschapsverhouding en de daarmee samenhangende lidmaatschapsrechten zijn onlosmakelijk verbonden met het aandeelhouderschap. Het ultieme lidmaatschapsrecht is het stemrecht; de mogelijkheid om door middel van de uitoefening van zeggenschapsrechten het beleid van de vennootschap mede te kunnen bepalen.

221 Handboek (1992), nr. 197.

222 S.E. Eisma, Preadvies 1990, p. 90. 
maar ook de lasten draagt. Dat geldt niet, althans in mindere mate voor de houder van certificaten die zonder medewerking van de vennootschap zijn uitgegeven. Hij staat uitsluitend in een persoonlijke rechtsbescherming (rechtsbetrekking?; $\mathrm{JH}$ ) tot de aandeelhouder. Tot de vennootschap staat hij niet in enigerlei relatie. Hem worden geen lidmaatschapsrechten toegekend. Dat neemt natuurlijk niet weg dat hij jegens het administratiekantoor gehouden is zich overeenkomstig de eisen van de redelijkheid en billijkheid te gedragen: dat vloeit voor uit hun verbintenis."

Schrijvers geven aan - Eisma expliciet en Van der Grinten impliciet - dat, bij de beantwoording van de vraag naar de kwalificatie van de verhouding certificaathouder - vennootschap, een onderscheid gemaakt dient te worden tussen houders van bewilligde certificaten en houders van certificaten die niet met medewerking der vennootschap zijn uitgegeven. Er bestaat een lidmaatschapsbetrekking tussen de houders van bewilligde certificaten en de vennootschap. ${ }^{223}$ De vennootschap heeft bewust meegewerkt aan het ontstaan van deze rechtsband. Immers, door het verlenen van medewerking aan de certificering stelt de vennootschap de weg open voor het toekennen van aandeelhoudersrechten aan niet-aandeelhouders. In dit eerste geval, dus het geval waarin de certificering van de aandelen met medewerking van de vennootschap heeft plaatsgevonden, luidt de conclusie dat de houders van deze bewilligde certificaten in een lidmaatschapsverhouding tot de vennootschap staan.

Wat is nu de rol van het wettelijk pandrecht in deze? Heeft het wettelijk pandrecht invloed op het ontstaan van de lidmaatschapsverhouding tussen certificaathouder en vennootschap? Mijns inziens staat het al of niet aanwezig zijn van het wettelijk pandrecht los van de vraag of er sprake is van een lidmaatschapsverhouding tussen de certificaathouder en de vennootschap. Immers, indien er sprake is van een wettelijk pandrecht, dan zal er altijd sprake zijn van met medewerking der vennootschap uitgegeven certificaten en indien hiervan sprake is, dan zal er altijd een lidmaatschapsverhouding tussen de houders van de bewilligde certificaten en de vennootschap bestaan. In het geval waarin het ontstaan van het - wettelijk pandrecht is uitgesloten (dit kan, zoals wij reeds zagen, worden bepaald in de statuten van de vennootschap, maar ook worden overeengekomen in de administratievoorwaarden) kan er toch een lidmaatschapsverhouding bestaan tussen vennootschap en houders van certificaten. Bepalend voor het ontstaan van die lidmaatschapsverhouding is het feit of de certificaten met medewerking der vennootschap zijn uitgegeven. Dus, wanneer er sprake is van een wettelijk pandrecht ten behoeve van de houders van certificaten, dan zal er altijd sprake zijn van een lidmaatschapsverhouding tussen de houders van de certificaten en de vennootschap. Ontstaat er geen wettelijk pandrecht ten behoeve van de certificaathouders in hun relatie tot het administratiekantoor, dan hoeft dit

223 Ook volgens Schwarz bestaat er een organisatierechtelijke betrekking tussen de vennootschap en de houder van de bewilligde certificaten; zie C.A. Schwar, TVVS 1992, p. 6. 
niet te betekenen dat de houders van certificaten niet als lid mogen worden beschouwd in de verhouding vennootschap - certificaathouders. Dit is afhankelijk van de vraag of de certificaten al dan niet met medewerking der vennootschap zijn uitgegeven. Heeft de vennootschap meegewerkt aan de certificering van aandelen in haar kapitaal dan is de houder van het - bewilligde - certificaat te beschouwen als lid in de verhouding vennootschap-certificaathouders, ongeacht dus de vraag of de positie van de certificaathouders versterkt is door het ontstaan van het wettelijke pandrecht.

We hebben dus gezien dat, in het geval er geen wettelijk pandrecht ten behoeve van de certificaathouders is ontstaan, er toch sprake kan zijn van een lidmaatschapsverhouding tussen vennootschap en certificaathouders. Dit is dan afhankelijk van de vraag of er sprake is van een bewilligde certificeringshandeling. Echter, het bestaan van deze lidmaatschapsverhouding is geen vanzelfsprekendheid. Indien er geen wettelijk pandrecht ontstaat, kan dit tweeërlei betekenen. Enerzijds kan dit leiden tot de conclusie dat het wettelijk pandrecht, ondanks medewerking der vennootschap statutair of contractueel, is uitgesloten, anderzijds kan dit ook het gevolg zijn van het feit dat de vennootschap geen medewerking aan de certificering heeft gegeven. Hoe nu in dit laatste geval te oordelen over het bestaan van een lidmaatschapsverhouding tussen certificaathouder en vennootschap?

Wanneer de vennootschap geen medewerking heeft verleend aan de certificering van aandelen in haar kapitaal heeft zij kennelijk willen voorkomen dat er een lidmaatschapsverhouding ontstaat tussen de vennootschap en de certificaathouder. Dus, geen medewerking, geen lidmaatschapsverhouding. Is deze stelling nu onverkort vol te houden? Met andere woorden, kan er ondanks het ontbreken van de medewerking van de vennootschap aan de certificering van aandelen toch een lidmaatschapsverhouding ontstaan? Onder omstandigheden zou ik deze vraag bevestigend willen beantwoorden. Men stelle zich de volgende gevallen voor. De op naam gestelde aandelen in een vennootschap worden zonder medewerking van de vennootschap gecertificeerd. Er ontstaat dan geen wettelijk pandrecht en er ontstaat in beginsel geen lidmaatschapsbetrekking tussen vennootschap en houders van de - onbewilligde - certificaten. In de statuten van de uitgevende instelling, de vennootschap dus, is geen voorziening opgenomen met betrekking tot (de uitsluiting of beperking van) de verpanding van aandelen op naam. Nu vestigt het administratiekantoor een 'gewoon' pandrecht op (een of meer) door haar gehouden aandelen in de vennootschap ten behoeve van (een of meer afzonderlijke) certificaathouders. Stel nu voorts dat het stemrecht verbonden aan die aandelen wordt overgedragen aan de certificaathouder/pandhouder dan ontstaat er een lidmaatschapsverhouding tussen vennootschap en certificaathouder/pandhouder. Immers, in het vierde lid van art. $198 \mathrm{BW}$ wordt bepaald dat aan de pandhouder die stemrecht heeft de rechten toekomen die zijn toegekend aan de houders van bewilligde certificaten. Het moge duidelijk zijn dat hier een vrij academische kwestie aan de orde is. Immers, wanneer het stemrecht verbonden aan de 
gecertificeerde aandelen aan de certificaathouder zou toekomen dan zou de ratio van de certificeringsconstructie volledig doorbroken worden. Desalniettemin acht ik het denkbaar dat een situatie als hiervoor beschreven in de praktijk zou kunnen yoorkomen.

Minder academisch van aard is de volgende situatie. De feitelijke omstandigheden zijn gelijk aan die van het hiervoor beschreven geval met dien verstande echter dat het stemrecht verbonden aan de gecertificeerde/verpande aandelen niet wordt overgedragen aan de certificaathouder/pandhouder. In dit geval verkrijgt de certificaathouder/pandhouder niet de rechten van de houder van een bewilligd certificaat en ontstaat er dus geen lidmaatschapsverhouding tussen vennootschap en certificaathouder.

In het laatste geval zijn de feiten als volgt. De naamaandelen in een vennootschap zijn zonder medewerking van de vennootschap gecertificeerd. Er is dus wederom geen sprake van een wettelijk pandrecht. Immers, dit wettelijk pandrecht kan, zoals reeds eerder opgemerkt, slechts ontstaan indien er sprake is van medewerking en het ontstaan van het pandrecht niet is uitgesloten. Met zou in eerste instantie moeten concluderen dat ook hier geen lidmaatschapsverhouding ontstaat. Echter, ook in dit geval kunnen de omstandigheden aanleiding geven tot een andere gevolgtrekking. Wanneer de statuten van de vennootschap wier aandelen gecertificeerd zijn, conform het bepaalde in de slotzin van het vierde lid van art. $198 \mathrm{BW}$, stipuleren dat aan de pandhouder/certificaathouder, die geen stemrecht heeft, de rechten toekomen die bij wet zijn toegekend aan de houders van bewilligde certificaten, en niet anders is bepaald bij de vestiging van het pandrecht, ontstaat er een lidmaatschapsverhouding tussen de certificaathouder/pandhouder en de vennootschap.

Men mag - mijns inziens - dus concluderen dat, wanneer de vennootschap geen medewerking verleent aan de certificering van aandelen in haar kapitaal, onder omstandigheden toch een lidmaatschapsverhouding kan ontstaan tussen de vennootschap en de houder van - onbewilligde - certificaten.

De vraag of er een lidmaatschapsverhouding aanwezig is in de relatie vennootschap - certificaathouder is, onder andere, van belang voor de vraag of de certificaathouder behoort tot de kring van art. $8 \mathrm{BW}$. Een bevestigende beantwoording van deze vraag betekent dat de certificaathouder een vordering kan instellen tot vernietiging van een besluit van een orgaan van de vennootschap op grond van art. 8 jo 15 lid 2 sub b BW. Art. 8 BW luidt als volgt:

\footnotetext{
"Een rechtspersoon en degene die krachtens de wet en de statuten bij zijn organisatie zijn betrokken, moeten zich als zodanig jegens elkander gedragen naar hetgeen door redelijkheid en billijkheid wordt gevorderd."
} 
Het criterium om toegelaten te worden tot de kring van art. 8 BW wordt gevormd door de organisatorische betrokkenheid. Niet omstreden is het feit dat aandeelhouders, bestuurders, commissarissen en houders van beperkte rechten op aandelen ${ }^{224}$ behoren tot de kring van art. $8 \mathrm{BW}$. Zij staan in een organisatorische betrekking tot de vennootschap. Echter, behoren certificaathouders ook tot deze kring?

De tekst van het art. 7 BW (oud) was concreter:

"Een rechtspersoon, haar leden of houders van aandelen of van met medewerking der vennootschap uitgegeven certificaten van aandelen en zij die deel uitmaken van haar organen moeten zich als zodanig jegens elkander gedragen naar hetgeen door de redelijkheid en de billijkheid wordt gevorderd."

De tekst van art. $8 \mathrm{BW}$ is ten opzichte van de oude versie vereenvoudigd en algemener van aard. De strekking van het artikel is evenwel onveranderd gebleven. ${ }^{225}$

Ik zou hier het standpunt willen innemen dat slechts de certificaathouders die in een lidmaatschapsverhouding tot de vennootschap staan, toegelaten dienen te worden tot de kring van art. $8 \mathrm{BW}$. Dit zijn dus de houders van met medewerking der vennootschap uitgegeven certificaten, ongeacht het feit of er te hunner behoeve een wettelijk pandrecht is ontstaan. Voorts behoren tot de kring van art. 8 BW de certificaathouders die onbewilligde certificaten houden, maar stemgerechtigd houder zijn van een 'gewoon' pandrecht op de aandelen.

Voorts acht ik de certificaathouder/houder van een 'gewoon' pandrecht zonder stemrecht betrokken in de zin van art. 8 BW wanneer de certificaten met medewerking der vennootschap zijn uitgegeven. Tenslotte behoort de certificaathouder, ten gunste van wie een 'gewoon' pandrecht is gevestigd op de aandelen die gehouden worden door het administratiekantoor, aan wie de statuten van de vennootschap de rechten toekennen die krachtens de wet toekomen aan de houders van bewilligde certificaten, tot de kring van art. $8 \mathrm{BW}$.

Bestaat er geen lidmaatschapsverhouding tussen de certificaathouder en de vennootschap dan behoren de certificaathouders niet tot de redelijkheids- en billijkheids-kring van art. $8 \mathrm{BW}$. Dit leidt tot de, naar mijn mening, alleszins aanvaardbare consequentie dat certificaathouders die in geen lidmaatschapsverhouding tot de vennootschap staan nimmer een vordering tot vernietiging van een, door een orgaan van de vennootschap genomen, besluit kunnen instellen op grond van art. 8 jo 15 lid 2 sub b BW. Zou men tot een andere conclusie komen

224 Het moet dan natuurlijk wel gaan om houders van een openbaar pand.

225 Maeijer/Schreurs, p. 49. 
dan zou een certificaathouder die geen 'lid' is van de vennootschap mede het beleid binnen de vennootschap kunnen bepalen. In dat geval zou radicaal voorbij worden gegaan aan het belang van de vennootschap, die door het voorkomen van het ontstaan van een lidmaatschapsverhouding juist heeft willen bereiken de betrokkenheid van de kapitaalverschaffers zo gering mogelijk te houden.

Houders van certificaten die niet in een lidmaatschapsverhouding tot de vennootschap staan zijn natuurlijk niet volledig verstoken van een mogelijkheid te ageren tegen onredelijke en onbillijke besluiten. Indien hun belangen door deze besluiten worden geraakt kunnen zij, onder omstandigheden, een vordering instellen op grond van onrechtmatige daad. ${ }^{226}$ Voorts zijn zij, onder omstandigheden, bevoegd op grond van art. 346 onder b BW een enquêteverzoek in te dienen.

Wij hebben hiervoor steeds gesproken over de lidmaatschapsverhouding die, onder gegeven omstandigheden, kan ontstaan in de relatie certificaathouder vennootschap. Een andere interessante vraag zou kunnen zijn of door verpanding van een bewilligd certificaat eveneens een lidmaatschapsverhouding zou kunnen ontstaan tussen de houder van een pandrecht op het certificaat en de vennootschap.

In zijn algemeenheid dient te worden opgemerkt dat bij verpanding van aandelen de lidmaatschapsrechten bij de aandeelhouder blijven berusten. Hier zou een parallel getrokken kunnen worden met de verpanding van certificaten van aandelen. De verpanding van certificaten leidt er niet toe dat lidmaatschapsrechten van de certificaathouder overgaan op de pandhouders, tenzij anders overeengekomen.

Ten aanzien van de open vennootschap, waar als kenmerk geldt dat de aandelen en certificaten van aandelen vrij verhandelbaar zijn, is het zo dat men het aandeel/certificaat kan verpanden en kan overeenkomen dat de lidmaatschapsrechten overgaan.

Met betrekking tot de verpanding van een bewilligd certificaat van een aandeel in een besloten vennootschap het volgende. Het systeem van de wet is zo dat overdracht van het aandeel, waarbij het stemrecht steeds overgaat op de verkrijger, niet vrijelijk mogelijk is en dat als een sequeel daarvan de overdracht van het stemrecht aan de pandhouder eveneens niet vrijelijk mogelijk is. Ten aanzien van de overdracht van (bewilligde) certificaten kent de wet geen voorziening, maar het ligt, althans bij de werkelijk besloten vennootschappen, voor de hand de mogelijkheid van die overdracht te beperken zoals ten aanzien van aandelen is geschied, omdat bij de overdracht van het bewilligd certificaat de lidmaatschapsrelatie op de verkrijger overgaat. Ook ten aanzien van de verpanding van

226 Zie ook F.J.P. van den Ingh, diss. p. 262. 
bewilligde certificaten is in de wet geen voorziening aan te treffen, zodat moet worden aangenomen dat zo'n verpanding steeds mogelijk is en dat ook de lidmaatschapsrechten aan het bewilligde certificaat verbonden kunnen worden overgedragen aan de pandhouder, tenzij statutair anders is bepaald. ${ }^{227}$

De conclusie moet derhalve zijn dat de overdracht van lidmaatschapsrechten aan de pandhouder van het bewilligde certificaat tot de mogelijkheden behoort, tenzij die mogelijkheden statutair zijn beperkt of uitgesloten. Bij bewilligde certificering van aandelen in een werkelijk besloten vennootschap is een zodanige statutaire voorziening essentieel.

De vraag kan nu worden opgeworpen wat rechtens is indien in de administratievoorwaarden van het administratiekantoor is bepaald dat de overdracht van bewilligde certificaten is onderworpen aan een blokkeringsregeling van gelijke aard en strekking als de blokkeringsregeling die in het kader van de overdracht van de aandelen in de statuten van de besloten vennootschap is opgenomen.

Verdedigbaar zou hier zijn dat uit een zodanige bepaling voortvloeit dat, bij verpanding van bewilligde certificaten door de certificaathouder, het lidmaatschapsrecht aan die certificaten verbonden slechts kan overgaan op de pandhouder, op een wijze als is voorzien ten aanzien van de overdracht van de certificaten. Nu dit standpunt slechts verdedigbaar is door een beroep op de overeenkomstige toepassing van de statutaire bepaling op deze situatie, samenhangend met de ratio van die bepaling, lijkt mij, met het oog op de bescherming van het besloten verband van aandeelhouders binnen de vennootschap, een voorziening ten aanzien van de beperking van de overgang van lidmaatschapsrechten op de pandhouder van het bewilligde certificaat sterk aan te bevelen. Deze voorziening zou, nu het om bewilligde certificaten gaat, waarmee de lidmaatschapsverhouding van

227 Interessant in deze is de opvatting van de Amstendamse rechtbank in de zaak Eemswater Beheer BV c.s./Houthof c.s. (HR 21 april 1995, RvdW 1995, 96c (met conclusie van A-G De Vries Lentsch-Kostense in Conclusies RvdW 1995, afl. 15, C96)). De rechtbank overweegt (R.O. 8): "Voorts blijts uit de administratievoorwaarden niet dat certificaathouders bevoegd zijn certificaten te verpanden (curs.JH), terwijl veel voor de hand zou hebben gelegen, indien een dergelijke bevoegdheid zou zijn beoogd, om daarin bepalingen op te nemen met dezelfde strekking als de hiervoor onder 8 besproken statutaire bepalingen hetgeen echter niet het geval is. Bovendien bepaalt art. 11 van de administratievoorwaarden: "Verpanding van ter certificering overgedragen aandelen is niet geoorloofd (curs.JH). " Noch het Hof noch de Hoge Raad gaan in op juistheid van deze overweging. Naar mijn mening is de opvatting van de rechtbank onjuist. Het feit dat de administratievoorwaarden geen bepaling bevatten waarin verpanding van certificaten van aandelen op naam wordt toegestaan, betekent m.i. niet dat certificaathouders niet bevoegd zouden zijn hun certificaten te verpanden. In gelijke zin F.J.P. van den Ingh, diss. p. 133: "Vestiging van een recht van vruchtgebruik of een pandrecht (curs.JH) op een certificaat is mogelijk, tenzij de administratievoorwaarden zulks uitsluiten." Dat de rechtbank verwijst naar het bepaalde in art. 11 van de administratievoorwaanden doet aan mijn opvatting niets af. Het gaat daar immers niet over verpanding van certificaten, maar over verpanding van de gecertificeerde aandelen. 
certificaathouder ten opzichte van de vennootschap is gegeven, zowel in de administratievoorwaarden, als ook in de statuten van de vennootschap moeten worden opgenomen.

Een volgende interessante vraag is die naar de consequenties van een royement van verpande certificaten. Stel het geval waarin een certificaathouder die zijn certificaten heeft verpand tot royement wenst over te gaan. Een royement leidt tot de contractuele verplichting tot overdracht van aandelen door het $\mathrm{AK}$ aan de certificaathouder, onder gelijktijdige verdwijning van het certificaat, een en ander ten titel van beëindiging van beheer. ${ }^{28}$ Vraag is wat het lot is van het pandrecht bij dit evenement. Als ik goed zie zijn hier twee visies denkbaar.

De eerste is die, waarin wordt aangenomen dat het aandeel bij de royering het onderwerp van het pandrecht gaat uitmaken. In deze visie redeneert men in de sfeer van zaaksvervanging, zo men wil omwisseling van een certificaat in een aandelen. Deze visie is niet de mijne immers, het certificaat vormt een geheel ander recht, namelijk primair ziende op de relatie certificaathouder - administratiekantoor, dan het aandeel. Ik vermag dan ook niet in te zien, dat het gevolg van de royering zou zijn dat het pandrecht op het aandeel komt te berusten. Dit zou, overigens, ook onmogelijk zijn in de zeker niet ondenkbare situatie dat certificaten zijn verpand, terwijl in de statuten van de vennootschap de mogelijkheid van verpanding van aandelen uitdrukkelijk is uitgesloten.

De andere visie zal concluderen tot het vervallen van het pandrecht, nu immers, door de royering, het object van het pandrecht teniet gaat, welk feit, in mijn visie het einde van het pandrecht met zich mee brengt. Het lijkt mij dan ook, in voorkomende gevallen, buitengewoon nuttig in de pandovereenkomst met betrekking tot het certificaat een voorziening op te nemen die ertoe moet leiden dat de certificaathouder niet zonder betrokkenheid van de pandhouder tot royering mag overgaan, een en ander met een fraaie dwangsom verzekerd. Op deze wijze immers zou de pandhouder in staat zijn een vervangende zekerheid te bedingen. Zodanige contractuele bepaling zou overigens slechts werken in die gevallen waarin royering plaatsvindt op instigatie van de certificaathouder en geen dekking geven voor die gevallen waarin het beheer van de aandelen wordt beëindigd op initiatief van het AK. In zo'n geval is de conclusie dat het pandrecht teniet gaat. En voor die gevallen lijkt het dan ook zinvol de eis van vervangende zekerheidsstelling in de pandovereenkomst op te nemen.

228 Zie F.J.P. van den Ingh, diss. p. 80. 


\section{I.10.6 Executie van het wettelijk pandrecht}

Het wettelijk pandrecht ten behoeve van de certificaathouders kan alleen worden uitgeoefend in geval van 'niet-uitbetaling van het hun verschuldigde', aldus art. 3:259 lid 3 BW. Van den Ingh merkt op dat de term 'het verschuldigde' in vermogensrechtelijke zin dient te worden opgevat. Onder 'het verschuldigde' vallen alle rechten van vermogensrechtelijke aard die een certificaathouder aan de contractuele relatie met het administratiekantoor kan ontlenen. Andere dan vermogensrechtelijke vorderingen en rechten van certificaathouders, zijn niet door het pandrecht verzekerd. ${ }^{229}$

Partijen kunnen, zoals reeds eerder opgemerkt, het wettelijk pandrecht beperken of zelfs helemaal uitsluiten. Art. 3:259 BW heeft dus geen dwingendrechtelijk karakter.

Wanneer het wettelijk pandrecht wordt uitgesloten, kan dus een gewoon pandrecht gevestigd worden. Mijns inziens kan mede op basis van het vorenstaande verder gepleit worden in de richting van de door Van den Ingh aangegeven mogelijke wijziging van art. 3:259 BW. ${ }^{230}$

Van den Ingh acht het onredelijk bezwarend indien het wettelijk pandrecht in de administratievoorwaarden wordt uitgesloten en tegelijkertijd niet een gewoon pandrecht gevestigd wordt. ${ }^{231}$ Krijgt men dan geen rare situatie? Mijns inziens zijn er twee gevallen denkbaar. Er zijn certificaten met medewerking van de vennootschap uitgegeven en in de administratievoorwaarden is uitdrukkelijk bepaald dat het wettelijk pandrecht uitgesloten is. De houder van deze certificaten is met deze bepaling akkoord gegaan, immers, ware dit niet het geval dan was hij geen certificaathouder geworden. Partijen zijn het eens over het feit dat een pandrecht - wettelijk danwel conventioneel - geen deel uitmaakt van hun rechtsverhouding. Het komt mij dan ook enigszins vreemd voor in dit geval te spreken van een onredelijk bezwarende situatie indien - buiten de wens van partijen om geen gewoon pandrecht ten gunste van de certificaathouder wordt gevestigd. Een ander geval waarin men naar mijn mening moeilijk kan spreken over onredelijk bezwarende omstandigheden is dat waarin certificaten zonder medewerking der vennootschap zijn uitgegeven. Een wettelijk pandrecht ontstaat niet. Toch gaan partijen - certificaathouder en administratiekantoor - een rechtsverhouding aan. Het al dan niet aanwezig zijn van een pandrecht hoeft geen reden te zijn voor het aangaan van een certificeringsverhouding. Sterker nog, het kan uitdrukkelijk de

229 F.J.P. van den Ingh, diss. p. 185 (noot 104).

230 Van den Ingh pleit voor een redactionele aanpassing van het tweede lid van art. 3:259 BW in de richting van art. $198 \mathrm{BW}$. De strekking van het tweede lid zou dan zijn dat het wettelijk pandrecht steeds ontstaat, tenzij de vennootschap het statutair uitsluit. Zie F.J.P. van den Ingh, diss. p. 101 en 186.

231 F.J.P. van den Ingh, diss. p. 186. 
bedoeling van de vennootschap zijn dat er in het geheel geen verhouding tussen de feitelijke kapitaalverschaffer en de vennootschap ontstaat.

In het derde lid van art. 3:259 BW wordt voorts bepaald welke procedure partijen in acht moeten nemen indien eén of meer certificaathouders het pand geheel of gedeeltelijk willen verkopen teneinde zich uit de opbrengst daarvan te voldoen. Ondanks het feit dat het pandrecht van art. 3:259 BW een gezamenlijk pandrecht ten behoeve van alle certificaathouders is, kan een individuele certificaathouder tot - gedeeltelijke - verkoop van het pand overgaan. ${ }^{232}$

Geheel in zijn eentje kan de certificaathouder niet tot executie van het pand overgaan. Hij dient zich, in afwijking van de hoofdregel van art. 3:248 lid $1 \mathrm{BW}$, te wenden tot de president van de rechtbank van de woonplaats van degene die de certificaten heeft uitgegeven. Hij verzoekt de president een bewindvoerder over het pand te benoemen. Deze bewindvoerder - een vereffenaar - dient voor de verkoop van het pand en de verdeling van de opbrengst zorg te dragen. Stemmen niet alle certificaathouders met de verkoop van het pand in, dan wordt slechts het gedeelte van het pand dat overeenkomt met het recht van de 'executerende' certificaathouder(s) verkocht.

Door de verdeling van de opbrengst na verkoop van het pand, gaan de rechten van de verkopende certificaathouders jegens het administratiekantoor teniet. De bewindvoerder dient zich bij de verkoop van het pand te richten naar de statutaire blokkeringsregeling. De president van de rechtbank is bevoegd, op verzoek van een certificaathouder danwel ambtshalve, maatregelen te nemen in het belang van de certificaathouders die niet met de verkoop hebben ingestemd. Hij kan bepalen dat de verkoop door hem moet worden goedgekeurd, wil zij geldig zijn.

Van den Ingh $^{233}$ werpt de vraag op of, in dit geval, de mogelijkheid van art. 3:251 lid $1 \mathrm{BW}$ eveneens openstaat. Dit artikel bepaalt dat de president van de rechtbank, op verzoek van de pandhouder, een bedrag kan vaststellen waarvoor de aandelen aan de pandhouder kunnen verblijven. Van den Ingh merkt op:

"In casu zou dit neerkomen op een verblijving van (een gedeelte van) de gecertificeerde aandelen aan de betrokken certificaathouders, naar rato van ieders belang, zoals omschreven in het door de bewindvoender ingediende verzoekschrift. Hoewel de tekst van lid 3 stelselmatig over "verkoop" spreekt, zie ik geen bezwaren om een verblijving ook hier mogelijk te achten. ${ }^{\text {234 }}$

232 Van den Ingh merkt hieromtrent op dat de eis tot verkoop van het pand op gezamenlijk verzoek niet wordt gesteld daar dit zou meebrengen dat de initiatief nemende certificaathouders genoodzaakt zouden zijn de overige certificaathouders op te roepen. Dit zou leiden tot grote praktische problemen, er bestaat immers geen wettelijke verplichting tot het bijhouden van een register van certificaathouders. Zie F.J.P. van den Ingh, diss. p. 187.

233 F.J.P. van den Ingh, diss. p. 189.

234 F.J.P. van den Ingh, diss. p. 189. 
Naar aanleiding van deze stellingname van Van den Ingh dient mijns inziens te worden gewezen op het vierde lid van art. $474 \mathrm{~g} \mathrm{Rv}$. Hierin wordt bepaald dat bij de executoriale verkoop en overdracht, de wettelijke en statutaire bepalingen ter zake van vervreemding van aandelen in acht moeten worden genomen. In art. 198 lid 5 BW wordt bepaald dat de tot executie overgaande pandhouder verplicht is de statutaire blokkeringsregelingen na te leven. Art. 3:251 BW kan dus slecht met inachtneming van art. $474 \mathrm{~g} \mathrm{Rv}$ jo 198 lid 5 BW worden toegepast.

In geval van faillissement van het administratiekantoor kunnen de certificaathouders - gelijk de overige crediteuren - zich verhalen op de boedel van het administratiekantoor. Het wettelijk pandrecht leidt ertoe dat er een ongelijkheid wordt gecreëerd tussen de schuldeisers van het administratiekantoor. De certificaathouders ten wiens gunste het wettelijk pandrecht is ontstaan verkrijgen de positie van separatist, zij kunnen zich met voorrang, boven de overige schuldeisers, verhalen op het vermogen van hun schuldenaar. ${ }^{235}$

235 Op de vraag of deze voorrang maatschappelijk gerechtvaardigd is ga ik niet in. Ik volsta met een verwijzing naar F.J.P. van den Ingh, diss, p. 191 en de in de noten 131-134 genoemde literatuur. 


\section{I.11 Beslag op en parate executie van aandelen door de pandhouder}

\section{I.11.1 Inleiding}

Het pandrecht is een beperkt zekerheidsrecht, strekkende om op de daaraan onderworpen goederen een vordering tot voldoening van een geldsom bij voorrang ${ }^{236}$ boven andere schuldeisers te verhalen, aldus het eerste lid van art. 3:227 BW. Art. 3:248 BW bepaalt dat indien de schuldenaar in verzuim is met de voldoening van hetgeen waarvoor het pand tot waarborg strekt, de pandhouder bevoegd is het verpande goed te verkopen en het hem verschuldigde op de opbrengst te verhalen. Vanwege het zekerheidskarakter van het pandrecht is de pandhouder bevoegd om bij executie over het goed te beschikken. Het recht om door middel van executie over het verpande goed te beschikken is, gelijk de rechten besproken in paragraaf I.8., een recht dat direct voortvloeit uit het beperkt zekerheidsrecht van pand.

De reden voor de aparte behandeling van het recht van executie is dat deze actie diep ingrijpt in het eigendomsrecht van de pandgever/aandeelhouder en daarnaast grote gevolgen kan hebben voor de - beslotenheid van de - vennootschap. ${ }^{237}$

Achtereenvolgens zal worden ingegaan op een aantal elementen die met het recht van executie samenhangen. Allereerst zal aandacht worden besteed aan de executie in het algemeen. Voorts wordt een onderscheid gemaakt tussen het executoriaal beslag en het conservatoir beslag op aandelen in een naamloze danwel besloten vennootschap. Gezien het onderwerp van dit onderzoek zal de nadruk voornamelijk liggen op het beslag op aandelen op naam. Vervolgens passeert de pandexecutie van aandelen de revue. Tenslotte zullen de gevolgen van de executie voor de pandgever/aandeelhouder en de vennootschap in kaart worden gebracht.

\section{Een schot voor de boeg}

A heeft een direct opeisbare geldvordering op B. Partijen zijn overeengekomen dat B zijn schuld aan A in termijnen zal lossen. Na enige maanden correct zijn betalingsverplichtingen te zijn nagekomen, staakt B, zonder opgaaf van redenen,

236 De wet geeft een aantal uitzonderingen waarin de pandvordering niet de hoogste plaats inneemt in de rangorde van verhaal, zie hiervoor Asser-Mijnssen, Zakenrecht III nr. 381 e.v.

237 De gevolgen van executie van grote pakketten aandelen kunnen met name groot zijn voor de besloten vennootschap met beperkte aansprakelijkheid en voor de besloten naamloze vennootschap (zie art. $335 \mathrm{BW}$ ), hierover later meer. 
zijn aflossingen. Zelfs na herhaalde sommatie van de zijde van A, hervat B zijn betalingen niet. A zoekt zijn heil bij de rechter. Hij eist dat B wordt veroordeeld tot betaling van de resterende termijnen. De rechter wijst de vordering van $A$ toe en veroordeelt $B$ conform de eis. Is hiermee nu een eind gekomen aan A's slapeloze nachten? Het antwoord op deze vraag is afhankelijk van B's reactie op het veroordelend vonnis van de rechter.

Het is denkbaar dat B, aangespoord door het rechterlijk vonnis, zijn verplichtingen in overleg met A weer zal nakomen. Partijen regelen dan in onderling overleg op welke wijze aan het vonnis van de rechter gevolg wordt gegeven. Let wel, hier wordt de meest voordelige opstelling/reactie van B jegens A geschilderd. Veelal zal deze idylle niet sporen met de realiteit.

Laconiek zou men kunnen opmerken, geen man over boord, immers A heeft een veroordelend vonnis dus is hij gerechtigd B's goederen uit te winnen om zo verhaal te zoeken. A zou dus, na het verkrijgen van het vonnis, bij B kunnen aankloppen en goederen van B, die in waarde overeenkomen met de hoogte van de vordering, kunnen opeisen. Hier zitten echter twee adders onder het gras.

In de eerste plaats verbiedt de Nederlandse wet eigenrichting.

"Voor het geval hij (de schuldenaar; $\mathrm{JH}$ ) niet meewerkt stelt de wet de rechthebbende enige middelen ten dienste, die ten doel hebben diens rechten uit het vonnis te verwerkelijken. Laatstgenoemde mag niet zelf met dwang of geweld zijn rechten vervolgen (...). Tenuitvoerlegging is een taak van de Staat, waarmee bepaalde ambtenaren, de deurwaarders, zijo belast. $^{\text {"2218 }}$

In de tweede plaats kan B de verhaalsmogelijkheden van A compleet denkbeeldig maken. Hij kan zijn bezittingen op naam van zijn partner zetten, deze verkopen, met een denkbeeldig recht belasten of op enige andere wijze doen verdwijnen. Ondanks het vonnis van de rechter vist $\mathrm{A}$ in dit geval achter het net. ${ }^{239}$

De vraag is nu wat $A$ moet ondernemen teneinde rechtsgeldig verhaal te krijgen op de goederen van B.

238 W.H. Heemskerk, Het nieuwe executie- en beslagrecht, $3^{e}$ druk, 1992, p. 1.

239 Enige nuancering is hier op zijn plaats. Er moet natuurlijk wel sprake zijn van een reële overdracht. Zo zullen titel, beschikkingsbevoegdheid en levering onontbeerlijk zijn. Voorts dient opgemerkt te worden dat het natuurlijk niet zo kan zo zijn dat B de tenuitvoerlegging van het vonnis volledig illusoir maakt ten gevolge van evidente schijnhandelingen. 


\section{I.11.2 Executie en beslag; algemene opmerkingen ${ }^{240}$}

"Executie is de door de wet toegestane en in de wet omschreven tenuitvoerlegging of verwerkelijking van een privaatrechtelijke aanspraak, neergelegd in een titel: vonnis of authentieke akte. ${ }^{\text {2201 }}$

De crediteur die tot executie van een vordering wenst over te gaan dient zich eerst te voorzien van een geldige executoriale titel. Art. 430 lid $1 \mathrm{Rv}$ geeft aan dat grossen van in Nederland gewezen vonnissen, van beschikkingen van de Nederlandse rechter en van in Nederland verleden authentieke akten alsmede andere bij de wet aangewezen stukken als executoriale titel kunnen dienen. ${ }^{242}$ Heeft de eiser een executoriale titel op zijn debiteur verkregen, dan kan hij verhaal zoeken op diens vermogen. ${ }^{243}$

Hij kan dit doen door het leggen van een executoriaal beslag. Daar dit veelal een tijdrovende procedure is loopt de executerende partij het gevaar dat de debiteur de goederen waarop het beslag gaat rusten laat verdwijnen. Teneinde dit te voorkomen kan de schuldeiser reeds voor het verkrijgen van een vonnis maatregelen nemen die pas na het verkrijgen van het vonnis kunnen worden uitgevoerd: de zogenaamde conservatoire maatregelen. Dit zijn maatregelen tot behoud van de rechten van de schuldeiser die pas na een vonnis kunnen worden uitgeoefend. ${ }^{244}$

Naast de executie door de schuldeiser op basis van een voorafgaande executoriale titel kent de Nederlandse wetgeving aan bepaalde schuldeisers een recht van parate executie toe. Dit is het recht om zonder een door een rechter of notaris afgegeven executoriale titel tot verhaal op goederen van de schuldenaar over te

240 Op deze plaats zullen slechts enkele algemene opmerkingen worden gemaakt ten aanzien van het leerstuk van het executie- en beslagrecht. Voor de finesse van de zaak verwijs ik naar $F . M . J$. Jansen, Executie- en beslagrecht, $4^{e}$ druk, 1990; Hugenholtz-Heemskerk, Hoofdlijnen van het Nederlands burgerlijk procesrecht, $17^{\circ}$ druk, p. 289 e.v.; P.A. Stein, Compendium van het burgerlijk procesrecht, $10^{\circ}$ druk, 1995; Burgerlijke rechtsvordering. H. Stein, II-1; Star Bussmann - Rutten - Ariëns, Hoofdstuk XI.

241 F.M.J. Jansen, Executie- en beslagrecht 1990, p. 1.

242 Een executoriale titel is een bevoegdelijk opgenaakte akte, die aan een bepaalde daarin vermelde persoon het recht verschaft om die akte met dwangmiddelen ten uitvoer te leggen; zie Hugenholtz - Heemskerk, 1994, nr. 257.

243 De grondslag van executie voor een geldvordering door het leggen van een executoriaal beslag gevolgd door de verkoop van de in beslag genomen goederen kan men vinden in art. 3:276 BW. Artikelen 447 en $448 \mathrm{Rv}$ geeft aan op welke goederen, behorende tot het vermogen van de debiteur, geen beslag mag worden gelegd.

244 Zie Hugenholtz-Heemskerk, 1994, nr. 255: te onderscheiden zijn drie soorten conservatoire maatregelen. 1. het gewone conservatoire beslag, 2 . het revindicatoire conservatoire beslag (het: conservatoir beslag tot afgifte of levering van roerende goederen) en 3 . het maritale conservatoire beslag. Zie ook W.H. Heemskerk, Het nieuwe executie- en beslagrecht, 1992, p. 2. 
gaan. Het recht van parate executie wordt onder meer toegekend aan de pand- en hypotheekhouder. ${ }^{245}$ Deze wijze van executie zal nader worden toegelicht in paragraaf 1.11.6.

\title{
I.11.3 Executie van aandelen aan toonder en aandelen op naam; algemeen
}

Verzuimt een debiteur zijn verplichtingen uit een overeenkomst van geldlening na te komen dan is de crediteur bevoegd zich langs de weg van executie te verhalen op het vermogen van de debiteur. Alvorens de crediteur tot executie van bepaalde goederen van de debiteur kan overgaan zal hij beslag op deze goederen dienen te leggen. In deze paragraaf zal worden ingegaan op het executoriaal beslag op rechten aan toonder (lees: aandelen aan toonder) en aandelen op naam in naamloze en besloten vennootschappen. ${ }^{246}$

\section{Achtergrond}

De eerste afdeling (A) van het tweede Boek van het Wetboek van Burgerlijk Rechtsvordering luidt: Van executoriaal beslag op rechten aan toonder of order, aandelen op naam en effecten op naam, die geen aandelen zijn. Deze afdeling is in het Wetboek ingevoerd bij Wet van 7 september 1972, Stb. 483, houdende Beslag op aandelen alsmede op effecten op naam en aan toonder. ${ }^{247}$ De reden tot indiening van het wetsvoorstel is gelegen in de veelvuldig geuite bezwaren, die in de literatuur werden aangevoerd, tegen de moeilijkheden die met de executie van aandelen (en met name aandelen op naam) samenhingen. ${ }^{248}$ Deze bezwaren vloeien mede voort uit de discussie omtrent het wezen van het aandeel en de vraag welke executiebepalingen van toepassing zijn op aandelen. Voor een juiste begripsvorming zal ik kort ingaan op deze discussie en de daarmee samenhangende bezwaren. Een exercitie dus binnen het recht van voor 1972 .

Cleveringa ${ }^{249}$ merkt aangaande het wezen van het aandeel op:

\begin{abstract}
"Enerzijds is geopperd, dat het aandeel de uitdrukking zou zijn van een vennootschappelijke schuld, ontstaan uit de uitgifteovereenkomst als verbintenis tegenover de inbreng verplichting; cen schuld, waarin verschillende gehoudenheden tot een eenheid zijn samengevat. De aandeelhouder is in deze opvatting schuldeiser der n.v.; dat zijn vorderingsrecht een samengesteld karakter heeft en niet enkel strekt tot betaling van gelden, maar ook tot heel iets anders als tot toelating tot medewerking aan regeling en beheer, doet hieraan geen
\end{abstract}

245 Zie Hugenholrz-Heemskerk, 1994, nr. 257; Burgerlijke rechtsvordering. H.Stein, aantekening 6, II. Inl. p. 10-14-15.

246 Burgerlijke Rechtsvordering, H. Stein, artt. 474a-474i, p. II (NRv)-425 e.v.

247 TK 11288 . De Wet is per 1 oktober 1972 in werking getreden.

248 TK 11288 , nr. 3, p. 4.

249 R.P. Cleveringa, Beslag op aandelen, NV 30 (1953), p. 202-203. 
afbreuk. Anderzijds heeft men den nadruk gelegd op juist dit laatste en het aandeel omschreven als het evenredig deel, waarin het lidmaatschap der naamloze vennootschap tot uitdrukking wordt gebracht; de aandeelhouder is geen schuldeiser, doch voor alles lid of vennoot. ${ }^{250}$

De inzet van de discussie was dus de vraag of men een aandeel nu zou moeten beschouwen als zijnde een 'inschuld' danwel als 'lidmaatschapsbewijs'. In samenhang met dit punt, was er de vraag of beslag op aandelen op naam mogelijk was, en zo ja op welke wijze dit beslag zou moeten plaatsvinden.

Ten aanzien van aandelen aan toonder bestond eenduidigheid. Aandelen aan toonder kunnen gelijk roerende goederen in beslag worden genomen en worden uitgewonnen. ${ }^{251}$

Op moeilijkheden stuitte men bij het leggen van beslag op aandelen die op naam gesteld zijn. Deze moeilijkheden waren inherent aan de onduidelijkheid die bestond ten aanzien van de vraag of een aandeel al dan niet kon worden beschouwd als zijnde een "inschuld" in de zin van art. 471 (oud) Rv. ${ }^{252}$ Beziet men een aandeel als een inschuld, dan kunnen de artt. 471-473 (oud) Rv van toepassing zijn. Voorwaarde is danwel dat uit 'titels of bescheiden' blijkt van het

250 Zie omtrent de vraag betreffende het wezen van het aandeel ook E.J.J. van der Heijden, Beslag op aandeelen, NV 12 (1934), p. 322; "Ook deze (aandelen op naam;JH) zijn roerende zaken door wetsbepaling (art. 567 B.W.). Doch roerende goederen zijn zij niet, omdat de wet onder goederen alleen lichamelijke zaken verstaat. Ook constructief vallen zij in het algemeen niet op écn lijn te stellen met roerende goederen, omdat het aandeelbewijs hier niet, gelijk bij het toonderaandeel, het recht vertegenwoordigt. De bezitter van het aandeelbewijs op naam geldt niet als bezitter van het recht, nog minder is hij gelegitimeerd als aandeelhouder. Een enigszins raadselachtig wetsarikel schijnt op het eerste gezicht hier hulp te bieden. In den tweeden titel van het tweede boek van het Wetboek van Burgerlijke Rechtsvordering, gewijd aan de gerechtelijke tenuitvoerlegging op roerende goederen, vindt men in art. 471 bepaald, dat, indien onder in beslag genomen roerende goederen worden gevonden inschulden, waarvan bij titels of bescheiden blijkt, tot verkoop van zoodanige inschulden kan worden overgegaan evenals ten aanzien van andere roerende goederen is bepaald. Deze hulp is echter weinig meer dan schijn. In de eerste plaats heeft het artikel alleen betrekking op "inschulden", onder welk begrip naar de gangbare opvatting aandelen niet zijn te begrijpen." Zie ook E.C. Henriquez, Beslag op aandelen op naam, TVVS 1973, p. 268; F.M.J. Jansen, Gerechtelijke executies van effecten, WPNR 4841 (1965), p. 1.

251 Zie ook E.E.J. van der Heijden, NV 12 (1934), p. 322: "Het aandeel aan toonder levert in dit verband geen bijzondere moeilijkheid. Dit recht is in zekere zin gematerialiseerd. De bezitter van bet bewijs aan toonder wordt als bezitter van het recht beschouwd en is daardoor als eigenaar van het recht gelegitimeerd. Het recht wordt uitgewonnen door uitwinning van het papier. Beslag op het recht, (...), wordt gelegd door het aandeelbewijs in beslag te nemen naar de regelen, voorgeschreven voor het beslag op roerend goed."

252 De tekst van art. $471 \mathrm{Rv}$ luidde: "Indien onder de in beslag genomen goederen worden gevonden inschulden, waarvan bij titels of bescheiden blijkt, kan tot verkoop van zoodanige inschulden worden overgegaan, even als ten aanzien van andere roerende goederen is bepaald, of wel voor zoo verre die inschulden opeiscbbaar zijn, bij beslag onder derden wordt geprocedeerd, op de wijze als bij de volgende afdeling is bepaald." 
bestaan van een inschuld. Ergo, er dienen aandeelbewijzen te bestaan van de aandelen op naam. Voorts dienen de inschulden 'opeisbaar' te zijn.

Van der Heijden is van mening dat naar 'gangbare opvatting' aandelen niet onder inschulden zijn te rangschikken. ${ }^{253}$ Zelfs al mocht men hier anders over denken, en aandelen wel als inschulden zien, dan is er, volgens Van der Heijden, nog geen bevredigende regeling. "Art. $471 \mathrm{Rv}$. geeft letterlijk alleen toestemming tot uitwinning (curs. origineel) van inschulden omtrent welke titels of bescheiden zijn gevonden. Het artikel onderstelt klaarblijkelijk, dat het voorafgegaan beslag op deze titels ook beslag op de inschulden heeft tot stand gebracht." Het is "twijfelachtig of de terloopsche mededeling van art. $471 \mathrm{Rv}$, dat onder de in beslag genomen goederen inschulden kunnen zijn bevonden voldoende is om zonder positieve wetsbepaling aan te nemen, dat door het beslag op de materieele titels de daarin beschreven inschulden zelf aan de beschikking van den beslagene zijn onttrokken." aldus Van der Heijden. ${ }^{254}$ Schrijver concludeert:

\begin{abstract}
"Kan men in dit alles, hoe gebrekkig ook, nog een begin van regeling zien voor het leggen van beslag op aandeelen op naam, waarvan bescheiden aanwezig zijn, volkomen laat de wet ons in de steek zoo dikwijls geen aandeelbewijzen worden aangetroffen. Dit geval is allerminst denkbeeldig. Voor aandeelen op naam immers heeft het aandeelbewijs slechts betrekkelijke waarde. De rechten van den aandeelhouder hangen van het bestaan daarvan niet af. Hoe zal men dan tot uitwinning geraken?"2ss
\end{abstract}

Biedt het derdenbeslag in dit geval uitkomst? Van der Heijden beantwoordt deze vraag terecht negatief. Het derdenbeslag leidt immers niet tot uitwinning van het aandeel. In de woorden van Van der Heijden:

\begin{abstract}
"(..) ook onder derden (kan;JH) alleen beslag worden gelegd op "inschulden", welke de geëxecuteerde van die derde mocht te vorderen hebben. (...) met het beslag onder den derde - in casu de naamlooze vennootschap waarvan de debiteur aandelen heeft - (valt; $\mathrm{JH}$ ) alleen te bereiken, dat de n.v. aan den executant moet betalen, hetgeen zij aan den aandeelhouder verschuldigd is. Hierdoor komt duidelijk uit, dat de wet, beslag op inschulden onder derden geregeld, niet aan het aandeel heeft gedacht. Want hetgeen de n.v. aan den aandeelhouder verschuldigd is en dus uit kracht van het beslag an den beslaglegger moet betalen, is in normale omstandigheden niet meer dan het aandeel in de winst, dat den aandeelhouder toekomt. Op deze wijze komt derhalve de waarde van het aandeel niet in handen van de beslaglegger. Hetgeen deze bereikt, is niet de uitwinning van het volle aandeelrecht. ${ }^{25 s}$
\end{abstract}

253 E.E.J. van der Heijden, NV 12 (1934), p. 322.

254 E.E.J. van der Heijden, NV 12 (1934), p. 322.

255 E.E.J. van der Heijden, NV 12 (1934), p. 323.

256 E.E.J. van der Heijden, NV 12 (1934), p. 323. In gelijke zin E.W. Catz, Beslag op aandeelen, NV 19 (1941), p. 300 . Zie ook TK 11 288, no. 3, p. 4: "Executoriaal derden beslag onder de vennootschap is ook niet afdoende. Acht men artikel 471 van toepassing, dan mag dit slechts gelegd worden "voorzover die inschulden opeisbaar zijn". Daardoor bereikt men zijn doel - 
Concluderend mag men stellen dat de schuldeiser die beslag wenst te leggen op aandelen op naam zich in een uitermate lastig parket bevindt indien er geen bewijzen van deze aandelen bestaan. ${ }^{257}$

Verdere bezwaren worden in de discussie gebracht door Cleveringa. Hij beschouwt aandeelhouderschap als schuldeiserschap van de vennootschap. ${ }^{258}$ Cleveringa komt op basis hiervan tot de conclusie dat, indien van bet aandeel een aandeelbewijs in omloop is, dit behoort tot de inschulden van art. 471 (oud) Rv. Uitwinning kan dan conform de artt. 472-473 (oud) $\mathrm{Rv}$ plaatsvinden door verkoop en levering van het bewijs. Is er geen aandeelbewijs, dan zijn tevens de genoemde artikelen niet van toepassing. Gelijk Van der Heijden vraagt ook Cleveringa zich af of derdenbeslag onder de vennootschap tot de mogelijkheden behoort en leidt tot het uiteindelijke doel, uitwinning van het aandeel.

\begin{abstract}
"Ondersteld moet dus nu worden, dat er ten laste van den aandeelhouder beslag is gelegd onder de n.v. (...); de n.v. moet nu komen verklaren, wat zij verschuldigd was of is geworden aan de aandeelhouder of van hem onder zich heeft; en dit moet dan, wil het derdenbeslag tot zijn doel leiden, voeren tot een vonnis, waarbij de n.v. veroordeeld wordt tot uitbetaling van verschuldigde gelden of afgifte van goederen (...), welke laatste de executant dan moet verkopen. Ook al is men bereid tot een ruime uitleg, het gaat niet aan de aandeelschuld aan te merken als een verbintenis, strekkende tot betaling van geld. Wel kan het aandeel geldelijke vruchten afwerpen, doch zij alleen maken het aandeel niet uit; ook b.v. het stemrecht behoort ertoe. ${ }^{\text {"2s? }}$
\end{abstract}

Cleveringa komt tot eenzelfde conclusie als Van der Heijden. De beslaglegger krijgt door middel van derdenbeslag het aandeel zelf niet, maar eventueel wel datgene wat de vennootschap aan dividend (mogelijkerwijs ook toekomstig dividend) aan de aandeelhouder verschuldigd is. Wel kan de executant "er den aandeelhouder, op wiens naam het staat, dwars mee zitten. ${ }^{260}$ Onder verwijzing naar de $5^{\circ}$ druk van Van der Heijdens "Handboek voor de naamloze vennootschap" (p. 284) besluit Cleveringa zijn artikel met het volgende citaat:

$256 \rightarrow$

uitwinning van het aandeel - niet: slechts de door de vennootschap aan de aandeelhouders verschuldigde dividend- en eventueel liquidatieuitkeringen vallen onder het beslag."

257 Hierbij wordt opgemerkt dat naar huidig positief recht de besloten vennootschap geen aandeelbewijzen mag uitgeven (art. $175 \mathrm{BW}$ ).

258 R.P. Cleveringa, NV 30 (1953), p. 203 (noot 14).

259 R.P. Cleveringa, NV 30 (1953), p. 205.

260 R.P. Cleveringa, NV 30 (1953), p.206. Het gegeven dat de executant, door middel van het dendenbeslag, de aandeelhouder dwars kan zitten, vloeit volgens Cleveringa voort uit het feit dat de aandeelhouder, ondanks stemgerechtigd te zijn, geen stem mag uitbrengen die het belang van de executant zou kunnen schaden. Deze 'redelijkheids- en billijkheids klem' blijft gedurende de gehele procedure rusten op het stemgedrag van de aandeelhouder, zie R.P. Cleveringa, NV 30 (1953), p. 205 en 206. 
"(...) gebrekkig is de regeling van het beslag op aandelen op naam wel. En er is daarom alle aanleiding zijn mening (Van der Heijdens mening; $\mathrm{JH}$ ) te onderschrijven, dat "bij toenemende omzetting van lichamelijk vermogen in aandelen deze toestand dringend verbetering vereist. ${ }^{n 261}$

Van der Heijdens conclusie wordt onderschreven in de MvT op het wetsvoorstel 11288 houdende "Beslag op aandelen op naam alsmede effecten op naam en aan toonder":

\begin{abstract}
"er is geen geldig motief te bedenken, waarom het de debiteur die houder is van aandelen op naam, makkelijker zou mogen vallen dan de debiteur die houder is van toonder-aandelen om die vermogensbestanddelen aan beslag te onttrekken. Ook moet het onjuist geacht worden dat verkoop van aandelen op naam ten bate van een crediteur in de praktijk alleen bereikt zou kunnen worden langs de weg van een faillissement, waarbij de curator, in voorkomende gevallen met in acht nemen van de blokkeringsbepalingen, bevoegd is de aandelen te gelde te maken. ${ }^{n} 262$
\end{abstract}

Na dit kort resumé aangaande de, in de literatuur geuite, kritiek op de eventuele toepasselijkheid van art. 471 (oud) Rv en de gebrekkig geachte regeling van beslag op aandelen, zal vervolgens worden ingegaan op het systeem van de, bij wet van 7 september 1972 ingevoerde, afdelingen 1A en 1B van het tweede Boek van het Wetboek van Burgerlijke Rechtsvordering. Bij de behandeling van deze afdelingen zal een onderscheid gemaakt worden tussen enerzijds de executie van aandelen aan toonder en anderzijds de executie van aandelen op naam. $\mathrm{Na}$ de behandeling van het executoriaal beslag zal aandacht worden besteed aan het conservatoir beslag op aandelen.

\title{
I.11.4 Executoriaal beslag op aandelen
}

\section{a. Algemeen}

Zoals reeds werd opgemerkt in paragraaf I.11.2. dient een schuldeiser aan een aantal voorwaarden te voldoen alvorens hij tot executie van goederen, behorende aan zijn schuldenaar, kan overgaan. Allereerst is daar de eis dat de executant dient te beschikken over een rechtsgeldige executoriale titel. Deze titel dient vatbaar te zijn voor tenuitvoerlegging jegens de schuldenaar. Verder wordt in art. $439 \mathrm{Rv}$, eerste lid, bepaald dat het beslag op de goederen vooraf moet worden gegaan door een exploit ${ }^{263}$ van de deurwaarder. In dit exploit is een tot de schuldenaar gericht bevel opgenomen om binnen twee dagen aan de executoriale

261 R.P. Cleveringa, NV 30 (1953), p. 206.

262 TK 11288 , no. 3 , p. 4.

263 In ant. $440 \mathrm{Rv}$ wordt een aantal fomele vereisten genoemd waaraan het exploit, op straffe van nietigheid, dient te voldoen. 
titel te voldoen. ${ }^{264}$ Pas na verloop van deze termijn kan executoriaal beslag op de goederen worden gelegd. De president van de rechtbank kan, op verzoek van de deurwaarder, de twee dagen-termijn inkorten.

Nadat het beslag door de deurwaarder is gelegd dient hij terstond, of uiterlijk op de volgende dag, over te gaan tot een specifieke aanduiding van de goederen die hij in beslag genomen heeft. In het door hem hiervan opgemaakte proces-verbaal dient hij de beslagen goederen nauwkeurig te beschrijven. Dit proces-verbaal wordt binnen drie dagen na de inbeslagneming betekend aan de geëxecuteerde en, in geval er een bewaarder is, ook aan deze; aldus art. $443 \mathrm{Rv}$.

Worden door de deurwaarder tijdens de beslaglegging gereed geld, aandeelbewijzen, effecten en ander geldswaarde bezittend papier aangetroffen, dan zal hij deze aan een door hem aan te wijzen volgens de Wet toezicht kredietwezen ingeschreven kredietinstelling of door zodanige kredietinstelling gegarandeerd effectenbewaarbedrijf of aan de Nederlandsche Bank NV in gerechtelijke bewaring dienen te geven. Deze regel leidt uitzondering indien de executant en de geëxecuteerde een andere plaats van bewaring zijn overeengekomen (art. 445 $\mathrm{Rv})$.

$\mathrm{Na}$ het beslag volgt logischerwijs de verkoop van het beslagene. De deurwaarder dient de dag en het tijdstip van de verkoop aan de geëxecuteerde te betekenen. Deze betekening vindt plaats samen met de betekening van het procesverbaal van inbeslagneming, danwel binnen een termijn van drie dagen na de betekening van het procesverbaal. De verkoop van het in beslag genomene vindt, op straffe van schadevergoeding, eerst na verloop van vier weken plaats. Deze termijn wordt gerekend vanaf de betekening van het proces-verbaal (als bedoelt in art. $443 \mathrm{Rv}$ ) aan de geëxecuteerde, aldus art. $462 \mathrm{Rv}$.

Art. $463 \mathrm{Rv}$, eerste lid bepaalt dat de verkoop van de in beslag genomen goederen in het openbaar en in het bijzijn van de deurwaarder zal geschieden. De plaats van verkoop zal gelegen zijn binnen het ambtsgebied van de deurwaarder. Het tweede lid van art. $463 \mathrm{Rv}$ geeft aan dat, indien de in beslag genomen goederen (aandelen) op een markt (beurs) verhandelbaar zijn, de verkoop kan geschieden in afwijking van de artt. 464-466 en $469 \mathrm{Rv}^{265}$ De verkoop dient in dit geval plaats te vinden op die markt door tussenkomst van een makelaar in het vak of ter beurze door die van een bevoegde tussenpersoon overeenkomstig de regels en gebruiken die daar voor een gewone verkoop gelden. De president van

264 In de praktijk is de gewoonte ontstaan de betekening van de executoriale titel en het bevel bij hetzelfde exploit te doen plaatsvinden. Het bevel is de eerste daad van de executie; zie W.H. Heemskerk, Het nieuwe executie- en beslagrecht, 1992, p. 15.

265 In deze artikelen wordt geregeld dat er een aankondiging van verkoop geschiedt in de gemeente waar de goederen verkocht worden, dat er biljetten dienen worden aangeslagen, dat er een aankondiging van de verkoop in een dagblad van de plaats van verkoop dient te geschieden en dat de verkoop bij opbod dient te geschieden. 
de rechtbank kan op verzoek van de beslaglegger of de geëxecuteerde een verkoop als hierboven bedoeld ook bepalen ten aanzien van effecten aan toonder die niet ter beurze verhandelbaar zijn (art. 463 lid $3 \mathrm{Rv}$ ).

In art. $470 \mathrm{Rv}$ wordt aangegeven dat de verkoop van de in beslag genomen goederen niet verder zal gaan dan nodig is om een opbrengst te verkrijgen die voor betaling van de schulden en kosten noodzakelijk is.

\section{b. Executoriaal beslag op aandelen op naam (artikel $474 c-i R v$ )}

Het executoriaal beslag op aandelen op naam in een naamloze of besloten vennootschap met beperkte aansprakelijkheid wordt gelegd bij exploit van de deurwaarder. Het beslag rust niet alleen op de aandelen maar ook op de nog niet aan de geëxecuteerde verantwoorde en afgedragen baten die voortvloeien uit het aandeel. Deze baten, men denke met name aan dividenden (maar ook aan stockdividenden), dienen aan de deurwaarder te worden verantwoord en op zijn verlangen aan hem te worden afgedragen. De vennootschap krijgt een afschrift van het deurwaardersexploit en tevens van de titel op basis waarvan beslag wordt gelegd (art. $474 \mathrm{c}$ lid $3 \mathrm{Rv}$ ). In het aandeelhoudersregister, dat door de vennootschap wordt gehouden, wordt terstond een aantekening geplaatst die de datum en het tijdstip van het gelegde beslag vermeld, alsmede de naam van de beslaglegger en het getal en zo mogelijk de nummers van de in beslag genomen aandelen. De aantekening dient, naast de ondertekening door de deurwaarder, tevens namens de vennootschap ondertekend te zijn.

De deurwaarder deelt het gelegde beslag onverwijld mee aan de schuldenaar. Het afschrift van het exploit dient, op straffe van verval van het beslag, binnen acht dagen aan de geëxecuteerde te worden betekend, aldus art. 474d Rv.

Gezien de strekking van het beslag lijkt art. $474 \mathrm{e}$ Rv min of meer overbodig te zijn. Het beslag heeft immers tot gevolg dat rechtshandelingen die met betrekking tot het goed worden verricht nadat beslag op het goed is gelegd geen afbreuk doen aan de rechten van de beslaglegger. ${ }^{266}$

Rechten die door een derde om baat zijn verkregen worden geëerbiedigd, indien de zaak in zijn handen is gekomen en hij op dat moment te goeder trouw was, dus geen weet had van het bestaan van het beslag (zie ook art. 453a Rv). ${ }^{267}$ Rechten die voor het beslagexploit reeds op de aandelen waren gevestigd, men denke bijvoorbeeld aan een pandrecht of een recht van vruchtgebruik, dienen onder opgave van de namen en de woonplaatsen van de gerechtigde, binnen acht dagen na het beslag, door de vennootschap aan de deurwaarder bekend te worden gemaakt.

266 Burgerlijke Rechtsvordering, $H$. Stein, art. 474e, aantekening 1 en 2, p. II.2-144-150.

267 Zie ook de artikelen 3:86 en $88 \mathrm{BW}$. 
In art. $474 \mathrm{~g} \mathrm{Rv}$, eerste lid wordt bepaald dat de beslaglegger binnen één maand na het exploit van het beslag aan de rechtbank van het arrondissement waarin hij bij beslagexploit domicilie heeft gekozen zal verzoeken bij beschikking te bepalen, dat en binnen welke termijn tot verkoop en overdracht van de in beslag genomen aandelen kan worden overgegaan. Wordt de termijn van één maand overschreden dan vervalt het beslag. Bij zijn verzoek aan de rechtbank voegt de beslaglegger zo mogelijk de mededeling van de vennootschap als bedoelt in art. 474f Rv en de statuten van de vennootschap. Alvorens de rechtbank de gevraagde beschikking geeft gelast hij de oproeping van de deurwaarder, de beslaglegger, de geëxecuteerde, de vennootschap, en, zo de rechtbank dit nodig acht, verdere belanghebbenden. Derde belanghebbenden kunnen zich uitsluitend bij wege van een tijdig ingediend verzoekschrift tegen verkoop van de in beslag genomen aandelen verzetten. Op deze procedure zijn de artt. 429a e.v. Rv van toepassing.

De rechtbank bepaalt op welke wijze en onder welke voorwaarden de verkoop en overdracht van de aandelen zal geschieden. Hierbij dient echter vermeld te worden dat de wettelijke en statutaire bepalingen betreffende de vervreemding van aandelen (de blokkeringsbepalingen), op grond van art. $474 \mathrm{~g}$ lid $4 \mathrm{Rv}$, in acht genomen dienen te worden. De ten aanzien van de vervreemding van de aandelen aan de aandeelhouder, onder wie geëxecuteerd wordt, toekomende rechten en verplichtingen dienen door de deurwaarder te worden uitgeoefend en nagekomen. Ook de beschikking van de rechtbank zal ten aanzien van de wettelijke en statutaire vervreemdingsbepalingen geen afwijkingen mogen inhouden. Dit is echter wel toegestaan indien de wettelijke en statutaire vervreemdingsbepalingen ertoe zouden leiden dat de executoriale verkoop onmogelijk zou zijn (art. 474g Rv). ${ }^{268}$

De deurwaarder maakt van de verkoop een proces-verbaal op. De koopprijs wordt hem ter hand gesteld. De aandelen worden niet bij notariële akte geleverd. De levering van de aandelen vindt plaats door aanbieding van het proces-verbaal van de verkoop ter registratie. Wil de nieuwe aandeelhouder de rechten verbonden aan de aandelen kunnen uitoefenen dient een afschrift van het proces-verbaal van de verkoop dat ter registratie is aangeboden en de grosse van de door de rechtbank gegeven beschikking aan de vennootschap betekend te worden. De vennootschap tekent de dag van de levering van de aandelen aan de executiekoper aan in het aandeelhoudersregister. ${ }^{269}$

268 Zie Arr. Rechtbank Amsterdam, 9 december 1975, NJ 1976, 276; Arr. Rechtbank Dordrecht, 19 oktober 1977, NJ 1978, 94.

269 Zie art. 474h Rv. Zie ook Burgerlijke Rechtsvordering, H. Stein, art. 474h, aantekening 2, p. II. 2-161. 


\section{c. Executoriaal beslag op aandelen aan toonder (artikel $474 a \mathrm{Rv}$ )}

Het beslag op rechten aan toonder geschiedt door beslag op het papier. Van toepassing zijn de eerste en de tweede afdeling en de tweede afdeling B van het Wetboek van Burgerlijke Rechtsvordering (dit zijn de artt. 439-497a en $479 \mathrm{~h}-$ 479k Rv).

\section{I.11.5 Conservatoir beslag op aandelen}

\section{a. Algemeen}

Voor het leggen van conservatoir beslag op goederen van de schuldenaar is, conform art. $700 \mathrm{Rv}$, het verlof vereist van de president van de rechtbank binnen welker rechtsgebied zich een of meer van de betrokken zaken bevinden. Het verzoek aan de president wordt gedaan bij wege van een verzoekschrift. Tenzij op het tijdstip van het verlof reeds een eis in de hoofdzaak is ingesteld, wordt het verlof verleend onder voorwaarde dat het instellen daarvan geschiedt binnen een termijn van acht dagen na het beslag. De president kan deze termijn verlengen op verzoek van de beslaglegger. ${ }^{270}$ Overschrijding van de gestelde termijn doet het beslag vervallen.

Het conservatoir beslag wordt gelegd overeenkomstig de voorschriften die gelden voor het leggen van executoriaal beslag tot verhaal van een geldvordering op een goed (art. $702 \mathrm{Rv}$ ).

Art. $711 \mathrm{Rv}$ bepaalt voorts dat het verlof om conservatoir beslag tot verhaal van een geldvordering te leggen op roerende zaken, niet-registergoederen en op rechten aan toonder of order slechts wordt verleend, indien de schuldeiser aantoont dat er gegronde vrees bestaat voor verduistering hetzij door de schuldenaar van zijn goederen hetzij door een ander.

Op het moment waarop de beslaglegger in de hoofdzaak een executoriale titel heeft verkregen en deze ten uitvoer gelegd kan worden, gaat het conservatoir beslag over in een executoriaal beslag. Voorwaarde hierbij is dat de verkregen titel aan de beslagene is betekend. Wordt de eis in de hoofdzaak afgewezen dan vervalt daardoor tevens van rechtswege het beslag (art. $704 \mathrm{Rv}$ ).

270 Voor het toekennen van een langere termijn zal vooral reden zijn indien de hoofdvordering voor arbiters of een buitenlandse rechter moet worden ingesteld, zie W.H. Heemskerk, Het nieuwe executie- en beslagrecht, 1992, p. 49. 


\section{b. Conservatoir beslag op aandelen op naam (artikelen 714-717 Rv)}

Met betrekking tot het conservatoir beslag tot verhaal van een geldvordering op aandelen op naam verklaart de wet de artt. 474b, tweede lid (bescherming van een schuldenaar te goede trouw), 474ba (uitoefening van het stemrecht verbonden aan de in beslag genomen aandelen) en 711 , eerste en tweede lid (conservatoir beslag op roerende zaken niet-registergoederen en op rechten aan toonder of order) van toepassing. Het beslag wordt gelegd op de wijze als bepaald in de artt. $474 \mathrm{c}-\mathrm{f} \mathrm{Rv}$.

Het beslagexploit houdt in waar de hoofdzaak aanhangig is of binnen welke termijn zij blijkens het presidentieel verlof moet worden ingesteld. Indien er nog geen eis in de hoofdzaak is ingesteld is de beslaglegger verplicht dit binnen acht dagen na dit instellen een afschrift van de dagvaarding aan de vennootschap te betekenen. De president van de rechtbank kan deze termijn verlengen, aldus art. $715 \mathrm{Rv}$, tweede lid.

Het beslag omvat ook de baten die de vennootschap uit de beslagen aandelen aan de aandeelhouder/beslagene verschuldigd is. Ten aanzien van deze baten geldt het beslag als een beslag onder de vennootschap. De vennootschap moet van deze baten een verklaring doen aan de rechtbank. (art. $716 \mathrm{Rv}$ ).

\section{c. Conservatoir beslag op aandelen aan toonder}

Art. $702 \mathrm{Rv}$, eerste lid geeft aan dat, tenzij de wet anders bepaalt, conservatoir beslag gelegd wordt met overeenkomstige toepassing van de voorschriften die gelden voor het leggen van executoriaal beslag tot verhaal van een geldvordering. Conservatoir beslag op aandelen aan toonder geschiedt dus door inbeslagname van het toonderpapier, het aandeelbewijs. Art. $713 \mathrm{Rv}$ bepaalt dat indien beslag wordt gelegd op een recht aan toonder de nog niet aan de geëxecuteerde verantwoorde en afgedragen baten, die voortvloeien uit dat recht, worden geïnd door de bewaarder van het papier.

Ten aanzien van het stemrecht verbonden aan de in beslag genomen aandelen geldt dat dit blijft berusten bij de aandeelhouder(pandhouder).

\section{I.11.6 Pandexecutie}

De crediteur die tot beslag ter verhaal van een geldvordering wenst over te gaan heeft, zoals gezegd, een executoriale titel nodig. Anders is de situatie voor de houder van een pandrecht. De pandhouder is bevoegd om zich bij voorrang boven andere crediteuren van de pandgever te verhalen zowel voor de hoofdschuld als voor de renten en kosten, indien de schuldenaar/pandgever met de voldoening van de geldschuld in gebreke blijft. De pandhouder is gerechtigd tot verkoop van het verpande goed over te gaan zonder dat hij hiervoor een executo- 
riale titel nodig heeft. ${ }^{271}$ De pandhouder beeft het recht van parate executie. Op deze executie zijn de artt. 3:248-255 BW van toepassing. Dit recht van parate executie komt aan de pandhouder toe voorzover partijen niet anders hebben bepaald. Art. 3:248 BW bepaalt immers:

"Partijen kunnen bedingen dat eerst tot verkoop kan worden overgegaan, nadat de rechter op vordering van de pandhouder heeft vastgesteld dat de schuldenaar in verzuim is. " 2372

Aan de pandhouder is het recht toegekend om na het opeisbaar worden van de vordering met de pandgever/schuldenaar overeen te komen dat het pand op een andere wijze wordt verkocht dan op de wijze in art. 3:250 bepaald (art. 3:251 lid 2 BW). Partijen kunnen beslissen het verpande onderhands te verkopen. De Hoge Raad overwoog reeds in 1929 dat een na het opeisbaar worden van de vordering tussen pandgever en pandhouder gesloten overeenkomst, waarbij de in pand gegeven aandelen aan de pandhouder werden gelaten tegen verplichting tot afrekening tegen middenkoers, rechtsgeldig was. Immers tijdens het aangaan van deze nadere overeenkomst stond de schuldenaar niet meer als kredietbehoevende tegenover zijn wederpartij en kon hij in dit opzicht onbelemmerd zijn belangen nastreven. ${ }^{273}$

Een pandhouder die tot verkoop van het verpande goed wil overgaan is verplicht, voorzover hem dit redelijkerwijs mogelijk is, de verkoop, ten minste drie dagen voor de voorgenomen datum van verkoop, aan de pandgever/schuldenaar mede te delen onder vermelding van plaats en tijd. Aldus art. 3:249 lid 1 BW. Deze bepaling is van regelend recht, partijen kunnen ervan afwijken. ${ }^{274}$ De van de pandhouder uitgaande mededeling moet zo nauwkeurig mogelijk de som aangeven waarvoor het pand kan worden gelost. Lossing kan tot op het tijdstip van de verkoop plaatsvinden, mits ook de reeds gemaakte kosten van executie worden voldaan (art. 3:249 lid 2 BW). Deze bepaling is nodig om te voorkomen dat de

271 In een onder het oude recht gewezen arrest van de Hoge Raad werd bepaald dat het partijen, op het moment van in gebreke zijn van de debiteur, vrij staat te bepalen, dat tegen kwijtschelding de pandhouder het pand in eigendom mag behouden, al dan niet onder de verplichting voor de pandhouder een deel of het geheel van de eventuele overwaarde aan de pandgever uit te keren; zie HR 17 januari 1929, NJ 1929, 622 (Schild). Zie ook Pitlo/Reehuis, Heisterkamp, nr. 801. De bescherming van art. 3:235 BW (1200 oud BW), die aan de debiteur/pandgever geboden wordt, vindt in geval van verzuim niet langer doorgang.

272 Art. 3:248 lid $3 \mathrm{BW}$ bepaalt voorts dat een lager gerangschikte pandhouder of beslaglegger het verpande goed slechts kan verkopen met handhaving van de hoger gerangschikte pandrechten. Deze bepaling zal tot gevolg hebben dat verkoop door lagere pandhouders in de praktijk niet vaak zal voorkomen; zie Asser Mijnssen, Zakenrecht MI, nr. 57.

273 F. Molenaar, Pandrecht, Mon. Nieuw BW, B12a, $2^{\circ}$ druk, 1991, p. 26; HR 17 januari 1929, NJ 1929,622 (Schild).

274 Van Zeben, Du Pon (I), p. 778. 
pandgever, te goeder trouw, een te lage som aanbiedt en daardoor de verkoop niet zou kunnen voorkomen. ${ }^{275}$

De verkoop geschiedt in het openbaar naar plaatselijke gewoonten en conform de gebruikelijke voorwaarden.

Bestaat het pand uit goederen die op een markt of beurs verhandelbaar zijn, dan kan de verkoop geschieden op een markt door tussenkomst van een makelaar in het vak of ter beurze door de tussenkomst van een bevoegde tussenpersoon overeenkomstig de gebruiken die aldaar voor een gewone verkoop gelden. De pandhouder mag meebieden (art. 3:250 BW).

Op grond van art. 3:251 BW kan de pandhouder, maar ook de pandgever de president van de rechtbank verzoeken de verkoop van het verpande goed op een andere wijze, dan die wordt bedoeld in art. 3:250 BW, te doen plaatsvinden. ${ }^{276}$ Zelfs kan de president van de rechtbank, op verzoek van de pandhouder, bepalen dat het pand voor een door de president vast te stellen bedrag aan de pandhouder als koper zal verblijven. In de MvA II op art. 3.9.2.12 NBW (art. 3:251 BW) wordt daaromtrent opgemerkt:

"De pandgever behoort echter niet bevoegd te zijn tot het in dit lid eveneens vermelde verzoek dat het verpande tegen een door de rechter vast te stellen bedrag aan de pandhouder als koper zal verblijven. Het initiatief tot het doen van dit verzoek moet uiteraard aan de pandhouder worden overgelaten. (...) Tevens is (...) tot uitdrukking gebracht dat deze rechter vrij is aan het verzoek al dan geen gehoor te geven."

Het opnemen van de mogelijkheid tot het doen van een verzoek door de pandhouder tot het aan hem verblijven van het verpande goed is noodzakelijk; een beding waarbij aan de pandhouder de bevoegdheid wordt gegeven zich het verbonden goed toe te eigenen is immers nietig (art. 3:235 BW).

Ten aanzien van de eigenmachtige verkoop van de verpande aandelen door de pandhouder en met betrekking tot het verzoek van de pandhouder aan de rechter de verpande aandelen onder zich te laten verblijven kent Boek 2 BW een voorziening. De leden 5 van de artt. 89 en 198 BW bepalen dat de bepalingen van de statuten met betrekking tot de vervreemding en de overdracht van aandelen van toepassing zijn op de vervreemding en de overdracht van aandelen door de

275 Van Zeben, Du Pon (I), p. 778/779; zie ook F. Molenaar, Pandrecht, Mon. Nieuw BW, B12a, $2^{\circ}$ druk 1991, p. 25.

276 Een mogelijke achterliggende reden voor pandhouder of pandgever het verpande op een andere wijze dan die van art. 3:250 te verkopen wordt gegeven in de M.v.A.II ten anzien van art. 3.9.2.12, Van Zeben, Du Pon (I), p. 782:" (..) Met name kan onder omstandigheden soms door onderhandse verkoop van b.v. zeer incourante effecten een hogere opbrengst worden verkregen. Daarom behoon ook de pandgever de bevoegdheid te bebben aan de rechter te verzoeken dat de door de pandhouder voorgenomen verkoop op een andere dan in art. 11 (art. 3:250; JH) aangegeven wijze zal plaatsvinden, (...)." 
pandhouder of de verblijving van de aandelen aan de pandhouder. De pandhouder oefent alle ten aanzien van de vervreemding en overdracht aan de aandeelhouder toekomende rechten uit en leeft diens verplichtingen daaromtrent na. Het is dus mijns inziens zo dat de executerend pandhouder te maken heeft met de statutair gedefinieerde vrije kring ten aanzien van de aandeelhouder. Uit deze bepalingen vloeit voort dat ook de pandhouder gebonden is aan de statutaire blokkeringsbepalingen. ${ }^{m}$

Het gevolg van deze bepalingen is dat, wanneer een houder van op naam gestelde aandelen in een besloten vennootschap zijn aandelen verpand heeft en vervolgens verzuimt zijn verplichtingen na te komen, de pandhouder niet zomaar tot executie van de aandelen kan overgaan. Kent de BV wier aandelen verpand zijn een statutaire aanbiedingsblokkade, dan zal de pandhouder de aandelen eerst dienen aan te bieden aan de mede-aandeelhouders van de pandgever. Reflecteren de mede-aandeelhouders niet (eventueel vanwege het feit dat zij afstand hebben gedaan van dit recht, danwel omdat zij niet in staat zijn het hele pakket contant over te nemen) dan kan de pandhouder alsnog overgaan tot verkoop aan een derde partij danwel het verzoek tot de rechter richten ten einde te bereiken dat de aandelen bij de hem kunnen verblijven.

Kennen de statuten van de besloten (naamloze) vennootschap een goedkeuringsblokkade dan zal de pandhouder de in pand genomen aandelen slechts kunnen verkopen of aan zich doen verblijven indien de aandeelhoudersvergadering (of een ander statutair hiertoe aangewezen orgaan) haar goedkeuring aan de verkoop/verblijving verleent, danwel de goedkeuring weigert zonder een andere gegadigde aan te wijzen.

Het bovenstaande zal natuurlijk niet spelen indien de pandhouder een persoon is aan wie de (verpande) aandelen zonder inachtneming van de statutaire blokkeringsbepalingen kunnen worden overgedragen. ${ }^{278}$

Op het verzoek van de pandhouder/gever als bedoeld in art. 3:251 BW is de verzoekschriftprocedure overeenkomstig de artt. 429a-s $R v$ van toepassing. Het verzoek het verpande op andere wijze te verkopen moet volgens art. $429 \mathrm{c}$ lid 6 Rv worden gedaan aan de president van de rechtbank, in wiens rechtsgebied zich de te executeren zaken geheel of grotendeels bevinden of de executie zal geschieden. ${ }^{279}$ Uiterlijk op de dag die volgt na die van de verkoop is de pandhouder verplicht kennis te geven van die verkoop aan de schuldenaar en de pandgever, alsmede aan hen die op het goed een beperkt recht hebben of daarop beslag hebben gelegd (art. 3:252 BW).

277 In gelijke zin Handboek (1992), nr. 184.

278 De pandhouder dient dan een persoon te zijn die tot de vrije kring van an. 195 lid 1 BW behoort.

279 Zie ook F. Molenaur, Pandrecht, Mon. Nieuw BW, B12a, 2e druk, 1991, p. 26. 
Art. 461a Rv dient hier te worden vermeld. Indien de in beslag genomen zaak is verpand (hetgeen bij een bezitloos pandrecht op een goed niet ondenkbaar is) en de pandhouder bevoegd is tot executie over te gaan, kan hij afgifte van de zaak vorderen, de executie overnemen en zelf executeren met inachtneming van de artt. 3:248-255 BW. De pandhouder die van deze bevoegdheid gebruik wenst te maken dient dit uiterlijk op het tijdstip van de verkoop bij exploit aan de beslaglegger aan te zeggen met opgave van de termijn binnen welke de pandhouder tot verkoop (of verzoek tot verblijving) over zal gaan. Vindt de aanzegging niet plaats dan blijft de beslaglegger bevoegd met de executie voort te gaan. De pandhouder behoudt echter zijn voorrecht op de opbrengst. ${ }^{280}$ Zijn er meerdere pandrechten op een zaak gevestigd dan komt de bevoegdheid tot overname van de executie slechts toe aan de hoogst gerangschikte pandhouder (art. 461a lid $2 \mathrm{Rv}$ )

\section{Executie en faillissement}

Aan het einde van deze paragraaf enkele overwegingen ten aanzien van de positie van de pandhouder in geval van faillissement van zijn schuldenaar/pandgever. In het faillissement van de pandgever is de pandhouder separatist. Dit wil zeggen dat de pandhouder zich in geval van faillissement kan gedragen als ware er geen faillissement; hij kan in deze situatie eveneens paraat executeren. (art. $57 \mathrm{Fw}$ ) De pandhouder moet binnen een redelijke termijn overgaan tot verkoop van het pand. Doet de pandhouder dit niet, dan kan de curator het pand opeisen en het zelf verkopen (art. $58 \mathrm{Fw}$ ). Het feit dat de curator de goederen verkoopt doet geen afbreuk aan het recht dat de pandhouder heeft op de opbrengst. De curator is tevens bevoegd het pand tegen volledige betaling te lossen (art. $58 \mathrm{Fw}$, tweede lid). Is de opbrengst niet toereikend om de vordering van de pandhouder volledig te voldoen, dan neemt deze, voor het resterende gedeelte van de vordering, de positie in van concurrent schuldeiser en kan als zodanig in de boedel opkomen. Executeert de pandhouder zelf en wordt het pand met een overwaarde verkocht dan vloeit deze overwaarde in de failliete boedel.

280 Zie W.H. Heemskerk, Het Nieuwe executie- en beslagrecht, 1992, p. 17. 



\section{I.12 Einde van het pandrecht}

Het pandrecht is een beperkt recht. Art. 3:81 lid 2 BW noemt de wijzen waarop een beperkt recht teniet kan gaan. Het artikel geeft een niet-limitatieve opsomming. ${ }^{281}$ Het pandrecht gaat teniet met het tenietgaan van de hoofdverbintenis, de vordering waarvoor het recht is verstrekt, waaraan het verbonden is. Dit ten gevolge van het accessoire karakter van het pandrecht. Ook door het tenietgaan van het goed, waarop het pandrecht is gevestigd, eindigt het pandrecht voor zover voor het tenietgegane goed geen ander goed in de plaats is getreden.

Executie van het pand leidt eveneens tot het tenietgaan van het recht. Door verloop van de tijd of vervulling van de ontbindende voorwaarde waarvoor het pand is gevestigd en door afstand van het pandrecht gaat het pand teniet. Vermenging van de persoon van de schuldeiser met die van de eigenaar van het verpande goed leidt eveneens tot einde van het pandrecht. Indien het verpande goed bestanddeel wordt van een niet met pand bezwaard goed, eindigt het pandrecht ook. Voorts komt er een einde aan het pandrecht door voltooiing van de verjaring van de rechtsvordering tot nakoming van de verbintenis, waarvoor het pand is gegeven. Dit geldt echter niet voor vuistpand.

Door schuldoverneming in de gevallen, dat pand verleend is op een, noch aan de oude, noch aan de nieuwe schuldenaar toebehorend goed; door overdracht van het met pand bezwaarde goed aan een derde te goeder trouw en door het in de macht van de pandgever geraken van het vuistpand, eindigt het pandrecht. ${ }^{282}$

Art. 3:256 BW bepaalt dat indien het pandrecht teniet is gegaan, de pandhouder verplicht is te verrichten hetgeen zijnerzijds nodig is opdat de pandgever de hem toekomende feitelijke macht over het goed herkrijgt. De pandhouder dient de pandgever, desgewenst, een schriftelijk bewijs ter hand te stellen waaruit blijkt

281 Beperkte rechten gaan teniet door: a. het teniet gaan van het recht waaruit het beperkte recht is afgeleid; b. verloop van de tijd waarvoor, of de vervulling van de ontbindende voorwaarde waarvoor het beperkte recht is gevestigd; c. afstand; d. opzegging, indien de bevoegdheid daartoe bij de wet of bij de vestiging van het recht aan de hoofdgerechtigde, aan de beperkt gerechtigde of aan beide is toegekend; e. vermenging en voorts op de overige in de wet voor iedere soort aangegeven wijzen van teniet gaan. Verdere gronden voor tenietgaan van het beperkt recht zijn: a. Verjaring van de rechtsvordering tot opheffing van een met het beperkte recht strijdige toestand, art. 3:106 NBW; b. een derde verkrijger van het goed wordt tegen het bestaan van een beperkt recht beschermd; $c$. bij executoriale verkoop door iemand tegen wie het beperkte recht niet kan worden ingeroepen; $d$. voor afhankelijke beperkte rechten: tenietgaan van het recht waaraan zij zijn verbonden, art. 3:82. Zie H.J. Snijders, E.B. Rank-Berenschot, Goederenrecht 1994, nrs. 478-481.

282 Zie omtrent bet tenietgaan van het pandrecht, F. Molenaar, Pandrecht, Mon. Nieuw BW, B12a, $2^{\mathrm{e}}$ druk, 1991, p. 79-82; Pitlo/Reehuis, Heisterkamp, Goederenrecht, nr. 784. 
dat het pandrecht is beëindigd. Is de vordering waartoe het pandrecht tot zekerheid strekte met een beperkt recht bezwaard, dan rust een overeenkomstige verplichting op de beperkt gerechtigde. 


\section{Deel II}

Verpanding van aandelen in relatie tot enkele

vennootschapsrechtelijke aspecten 



\section{Pandrecht op aandelen en de beslotenheid van de vennootschap}

\section{II.1 Inleiding}

Hiervoo ${ }^{283}$ heb ik aangegeven dat zowel op aandelen in een besloten vennootschap als op aandelen in een naamloze vennootschap een pandrecht kan worden gevestigd. In dit deel wordt aandacht besteed aan de gevolgen die het vestigen van een pandrecht op aandelen in een naamloze en besloten vennootschap kan hebben voor de beslotenheid van het samenwerkingsverband. Alvorens een theoretische beschouwing aangaande deze materie te geven zal ik eerst trachten te komen tot een omschrijving van de term 'beslotenheid'.

Het Nederlandse positieve recht kent twee vormen van kapitaalvennootschappen, de naamloze vennootschap en de besloten vennootschap. Echter, binnen deze twee vormen zijn verschillende varianten denkbaar. Deze varianten bevinden zich op een schaal die loopt van 'zeer open' tot 'absoluut be(ge)sloten'. In § II.5 zullen de verschillende typen naamloze en besloten vennootschappen besproken worden; aandacht zal worden besteed aan de intern-besloten vennootschap, de niet intern-besloten vennootschap, de open naamloze vennootschap, de intern-besloten naamloze vennootschap en de gemengde vennootschap.

Teneinde te komen tot een verklaring voor de gradaties binnen de beslotenheid van het samenwerkingsverband en daarmee tevens invulling te geven aan het begrip 'beslotenheid', acht ik het noodzakelijk in de wetsgeschiedenis van zowel de naamloze vennootschap als de besloten vennootschap met beperkte aansprakelijkheid te duiken. Gedurende deze - historische - exercitie zal vast komen te staan dat de wetgevers van 1928 en $1971^{284}$ onmiskenbaar een verschillende inhoud aan het begrip beslotenheid toekenden.

283 Duidelijkheidshalve zal ik de hoofdregels betreffende de mogelijkheid van verpanding van aandelen nogmaals - kort - weergeven. Allereerst de regeling betreffende de naamloze vennootschap. De bevoegdheid tot verpanding van een aandeel aan toonder kan statutair niet worden uitgesloten dan wel worden beperkt. Een pandrecht op een aandeel op naam in een naamloze vennootschap kan worden gevestigd, voor zover de statuten geen andersluidende bepaling bevatten (art. 89 lid $1 \mathrm{BW}$ ). Indien de statuten van een besloten vennootschap niet anders bepalen kan ook op de aandelen in dit samenwerkingsverband een pandrecht worden gevestigd (art. 198 lid $1 \mathrm{BW}$ ). Voor de wijze van vestiging verwijs ik naar hetgeen hieromtrent wordt opgemerkt in \$ 1.5 e.v. van mijn dissertatie.

284 In 1928 werd de "naamlooze vennootschap" en in 1971 "de besloten vennootschap met beperkte aansprakelijkheid ${ }^{n}$ in het Wetboek van Koophandel ingevoerd. 
Tot 1971 kende de Nederlandse wet alleen de naamloze vennootschap als vennootschappelijke rechtspersoonsvorm. De term besloten vennootschap, zoals wij deze in onze huidige wetgeving kennen, kwam toentertijd niet voor. ${ }^{285}$

Dit betekent echter geenszins dat de Nederlandse rechtspraktijk verstoken was van een zeker besloten samenwerkingsverband, waarmee door kapitaalverschaffers werd deelgenomen aan het maatschappelijk verkeer.

285 Handboek (1992), nr. 1. Zie ook J.M.M. Maeijer, Naar een eigen rechtsvorm voor de besloten vennootschap, NV 46 (1968), p. 25. 


\section{II.2 Naamloze vennootschap en besloten naamloze vennootschap}

Met ingang van 1 oktober 1838 werd, tegelijkertijd met de invoering van de nieuwe Nederlandse wetgeving, de naamloze vennootschap in het Nederlands rechtsstelsel - in het Wetboek van Koophandel - geïntroduceerd. ${ }^{286}$

De regeling van de naamloze vennootschap stond van meet af aan bloot aan kritiek. Kritiek die zich met name richtte op de eis van de Koninklijke bewilliging als voorwaarde voor de oprichting en op de beknoptheid van de regeling. ${ }^{287}$ Het duurde echter tot 1871 eer een voorstel tot wijziging van de regeling van de naamloze vennootschap werd gedaan. In dit ontwerp, het ontwerp Jolles $^{288}$, werd voorgesteld het preventief staatstoezicht te laten varen en, ter bescherming van belanghebbenden, een zekere mate van openbaarheid in te voeren. Op de introductie van deze wettelijk voorgeschreven openbaarheid liep het ontwerp Jolles stuk. Het ontwerp werd dan ook in 1872 ingetrokken. ${ }^{289}$

Een volgende poging, om tegemoet te komen aan de kritiek op de regeling van de naamloze vennootschap, werd ondernomen door de Staatscommissie tot herziening van het Wetboek van Koophandel. In 1890 werd het ontwerp, waarin de commissie voorstelde het preventief overheidstoezicht te laten vervallen en in plaats daarvan dwingendrechtelijke bepalingen op te nemen ter waarborging van de kapitaalrealiteit van de vennootschap alsmede de invoering van een verplichting tot verstrekkende openbaarheid voor bepaalde - financiële - gegevens van de vennootschap, openbaar gemaakt. Ook dit ontwerp leidde niet tot wetswijziging. 290

286 Handboek (1992), nrs. 11 en 12; dit geschiedde bij Koninklijk Besluit van 10 april 1838, Stb. 12. Zie voor de ontwikkeling van de naamloze vennootschap, Handboek (1992), nrs. 2-12. Zie ook E.J.J. van der Heijden, De ontwikkeling van de naamlooze vennootschap in Nederland voor de codificatie, diss. 1908.

287 Handboek (1992), nr. 15.

288 Bijblad van de Nederlandsche Staatscourant 1871-1872, TK Vel 240, p. 957. Uit de MvT op dit ontwerp het volgende citaat: "Reeds eenigen tijd heeft zich de behoeften doen gevoelen aan wijziging in de wettelijke regeling der naamlooze vennootschappen, (...). De bestaande regeling beantwoordt in menig opzicht geenszins aan de eischen van het maatschappelijk verkeer, en levert aan den eene zijde den handel stof tot klagen over belemmering en doodelooze moeijelijkheid, terwijl aan de andere zijde daarin voor derden geene afdoende waarborgen worden gevonden tegen bedriegelijke handelingen. De tegenwoordige wetvoordracht strekt om in onze gebrekkigen toestand verbetering aan te brengen, en met opheffing der bepalingen, welke geacht kunnen worden belemmerend te werken op de oprichting en ontwikkeling der naamlooze vennootschappen, tevens genoegzame waarborgen te verzekeren zoowel aan de vennooten zelve als aan derden, die met de vennootschap handelen."

289 Handboek (1992), nr. 16.

290 Handboek (1992), nr. 17. 
Het volgend bedrijf in het spel om de wijziging van de regeling van de naamloze vennootschap werd geregisseerd door minister Nelissen. In zijn "Ontwerp van wet tot wijziging en aanvulling van de bepalingen in het Wetboek van Koophandel omtrent de naamloze vennootschappen en daarmee samenhangende artikelen in het Wetboek van Strafrecht", bij de Tweede Kamer ingediend op 14 februari 1910, stelde ook hij voor het preventief staatstoezicht uit de regeling te schrappen. De speerpunten van zijn ontwerp waren de openbaarheid van de inrichting en de machtsverdeling, de bescherming van het vermogen en daarmede verband houdend een regeling betreffende de inbreng van andere zaken dan geld, een nadere regeling van de persoonlijke aansprakelijkheid van bij de vennootschap betrokken personen jegens aandeelhouders en derden en de bescherming van de belangen van de minderheidsaandeelhouder(s) tegen de grillen van de meerderheidsaandeelhouder(s). ${ }^{291}$ Het ontwerp Nelissen werd later veranderd door het gewijzigd ontwerp Heemskerk. Het gewijzigd ontwerp liet het overheidstoezicht ongemoeid en voerde een zekere verplichting tot het openbaar maken van bepaalde gegevens in. Ook dit ontwerp bleef niet vrij van kritiek. Niet het voortbestaan van het preventief overheidstoezicht, maar de verplichte openbaarmaking van de jaarlijkse balans en winst- en verliesrekening die voor alle naamloze vennootschappen zou gaan gelden, vormde de voornaamste bron van weerstand. De verplichting tot openbaarmaking van de jaarstukken zou zowel rusten op de open naamloze vennootschappen ${ }^{292}$, die zich bij het plaatsen van aandelen in hun kapitaal richten tot het beleggend publiek, alsmede op de besloten of familie vennootschappen, die juist geen beroep deden op het beleggend publiek.

Het gewijzigd ontwerp Heemskerk werd gevolgd door het nader gewijzigd ontwerp Donner. In dit ontwerp bleef de publikatieverplichting ongewijzigd gehandhaafd. Op 1 april 1927 werd het ontwerp door de Tweede Kamer aangenomen. In de Eerste Kamer werd het ontwerp echter onder vuur genomen. Wederom kwam het bezwaar tegen de gelijke publikatieplicht voor open en besloten naamloze vennootschappen naar voren. ${ }^{293}$ De Eerste Kamer wilde van de minister horen welke naamloze vennootschappen buiten de toepassing van de publikatieplicht zouden vallen. ${ }^{24}$ Nadat de minister de Kamer had toegezegd, na aanname van het door hem voorgestelde ontwerp, een adviescommissie te benoemen die zich opnieuw zou buigen over het vraagstuk van de publika-

291 Handboek (1992), nr. 19; TK 1909-1910, 217. 1-2.

292 Schwarz spreekt over 'publieke vennootschappen', C.A. Schwarz, diss. p. 25.

293 Zie voor de bezwaren die geuit werden door de leden van de Eerste Kamer tegen de verplicht gestelde openbaarmaking van verschillende bescheiden der vennootschap; Belinfanse 1929, p. 291-292.

294 Zie over de geschiedenis van de wijziging van de regeling van de naamloze vennootschap ook H.J. Hellema, De beperkte publikarieplicht van de BV, NV 48 (1970/1971), p. $72-73$. 
tieplicht, werd het voorstel van wet op 19 juni 1928 door de Eerste Kamer aangenomen en trad de wet per 1 april 1929 in werking. ${ }^{295}$

De Commissie van Advies inzake de nieuwe wettelijke regeling van de naamloze vennootschap werd bij besluit van 26 juli 1928 ingesteld. Zij kreeg de opdracht de minister "voor te lichten over de vraag of, en $z 00 \mathrm{ja}$, in hoeverre wijziging is te brengen in de nieuwe wettelijke regeling van de naamloze vennootschap."

Op 24 november 1928 bracht de commissie haar advies uit. ${ }^{296}$ Ook binnen de adviescommissie divergeerden de meningen ten aanzien van de publikatieverplichting voor naamloze vennootschappen. Een tweetal leden van de commissie stelde zich op het standpunt dat het voorschrift aangaande de verplichte openbaarmaking van de balans en de winst- en verliesrekening (art. $42 \mathrm{c} \mathrm{K}$ oud) zou moeten worden geschrapt. ${ }^{297}$ Een aantal andere leden van de commissie was het met het eerder genoemde standpunt in zoverre eens, dat het enkele feit dat een samenwerkingsverband in de rechtsvorm naamloze vennootschap werd gegoten, onvoldoende rechtsgrond bood voor een verplichte openbaammaking van de jaarstukken. Deze leden waren echter wel van mening dat de wet tot publikatie mocht verplichten indien daarvoor de vereiste rechtsgrond aanwezig was. Die rechtsgrond bestond volgens deze leden:

\begin{abstract}
"in de noodzakelijkheid van bescherming van het beleggend publiek dáár, waar de naamloze vennootschap zich ter verkrijging van hare middelen tot het publiek, althans mede tot het publiek, richtre en dus op het algemeene vertrouwen een beroep deed. Zulks was volgens deze leden in de eerste plaats het geval bij die N.V., wier waarden, aandeelen of obligaties, in de officieele prijscouranten der Nederlandsche beurzen zijn opgenomen en daardoor het publiek openbaar ter neming worden aangeboden en voorts, indien worden uitgeoefend enkele bepaalde bedrijven, waarbij op bijzondere wijze het publiek vertrouwen wordt ingeroepen, als b.v. bij het bankbedrijf. ${ }^{298}$
\end{abstract}

295 Handboek (1992), nr. 24.

296 TK 283, nrs. 1-4. Zie ook Belinfanse 1929, p. 337 e.v.

297 Argumenten voor dit standpunt waren de onjuiste opvarting, dat de verplichting tot publikatie van jaarstukken, welke de wet geen enkele andere vennootschapsvorm oplegde, gemotiveerd was door het bijzondere karakter van de naamloze vennootschap, een wettelijke publikatie plicht was onnodig ("omdat die verplichting slechts kan worden voorgestaan in het belang van aandeelhouders of van derden. Aandeelhouders nu hebben daaraan geen behoefte, omdat reeds elders voor hen is gezorgd, en wel in artikel $42 \mathrm{~b}$, hetwelk, en te recht, de naamlooze vennootschap verplicht tot nederlegging der ontworpen jaarstukken gedurende eenigen tijd, voorafgaande aan de vergadering, welke tot hunne behandeling is bestemd. Derden, die met een naamlooze vennootschap in handelsrelatie willen treden en daarbij aan een inzicht in den vermogenstoestand dier associatie behoefte mochten gevoelen, kunnen dat inzicht ongetwijfeld op andere en meer doeltreffende wijze verzekeren dan door het nasnuffelen der verschillende balansen en winsten verliesrekeningen ten kantore van het handelsregister.") en gevaarlijk; zie Belinfante 1929, p. 340-341.

298 Belinfante 1929, p. 341-342. 
Een volgende groep leden van de commissie was de mening toegedaan, dat in het wezen van de naamloze vennootschap wel voldoende grond voor het opleggen van een verplichting tot het openbaar maken van de jaarstukken was gelegen.

\begin{abstract}
"Dat het gehele vermogen der N.V. voor de in haar naam aangegane verbintenissen aansprakelijk was, nam volgens hen niet weg dat de natuurlijke personen, die in dien naam het bedrijf uitoefenden, slechts verantwoordelijk waren met dat deel van hun vermogen, hetwelk zij in dat bedrijf mochten hebben gestoken. Dat klemde zeker niet minder bij de besloten of familie vennootschappen dan bij de z.g. publieke vennootschappen. Waar de wetgever hen, die voor eigen rekening een bedrijf uitoefenen, toestaat een gedeelte van hun vermogen, zij het soms ook met hulp van anderen, om te zetten in een naamlooze vennootschap en daardoor dat in die zaak gestoken vermogen als het ware een eigen persoonlijkheid verleent, welker verbintenissen geheel los staan van het prive vermogen der deelnemers, bestaat er voor den wetgever alle reden om te zorgen dat de lotgevallen van dat afgezonderde vermogen niet verborgen blijven. Het is een noodzakelijke aanvulling van de voorschriften betreffende de openbaarheid van het kapitaalbedrag en de realiteit van het kapitaal. ${ }^{\text {299 }}$
\end{abstract}

Deze leden stelden zich desalniettemin op het standpunt dat dit niet in de weg behoefde te staan aan een verzachting van de publikatieverplichting. De leden waren bereid mede te werken:

\begin{abstract}
"tot een opheffing der publicatieverplichting in al die gevallen, waarin de openbaarmaking zonder bezwaar kon worden gemist, waarin althans haar nuttig effect kon geacht worden niet op te wegen tegen het gevoel van onlust en onbevredigdheid (...), welke die verplichting bij de betrokkenen opriep. In dat verband wilden zij, afgezien dan van enkele bijzondere bedrijven, de belangen van hen, die met de naamlooze vennootschap handelsbetrekkingen onderhielden, in dit opzicht niet te boog aanslaan, en zich beperken tot de belangen van derden, voor zoover deze nemers van vennootschapswaarden, aandelen of obligaties konden worden. De publicatieplicht diende onverzwakt te worden gehandhaafd, waar zulks voor de belangen van deze derden vereischt was, en zulks was vereischt indien de door de vennootschap uitgegeven waarden door den fondsenhandel werden geraakt. ${ }^{n 300}$
\end{abstract}

Welnu, volgens deze leden stond onomstotelijk vast dat de publikatieverplichting gehandhaafd diende te worden voor die naamloze vennootschappen wier aandelen of andere waardepapieren ter beurze werden verhandeld. Ook erkenden zij dat naast de beurshandel in vennootschappelijke waarden, een omvangrijke handel in incourante fondsen bestond. Deswege achtten deze commissieleden het onvoldoende de publikatieverplichting alleen aan die naamloze vennootschappen op te leggen, die ter beurze noteerden.

"Het ging volgens deze leden (...) niet aan, al de daarbij (bij de incourante bandel; JH) betrokken naamlooze vennootschappen van publicatieplicht viij te stellen. Ongetwijfeld waren er onder de naamlooze vennootschappen, welker waarden niet in de beursnotering 
waren opgenomen, een groot aantal, waarvan de aandelen binnen beperkten kring bleven, doch de bescherming van het publiek, (...), zou onvoldoende verzekerd zijn, indien met dezen aanzienlijken handel in incourante fondsen geen rekening werd gehouden. Het kwam er dus op aan het kenmerk te vinden, waardoor de eigenlijke besloten vennootschap, d.w.z. die, wier aandelen bestemd waren in beperkten kring te blijven, voldoende werd aangeduid. ${ }^{301}$

Uit de weergegeven standpunten van de, leden van de, adviescommissie komt duidelijk naar voren, dat de meerderheid voor handhaving van de publikatieverplichting van jaarstukken van - beursgenoteerde - naamloze vennootschappen was. Fundamenteel verschil van mening ontstond binnen de commissie over de vraag of, en in hoeverre, bij het ontbreken van beursnotering, een publikatieverplichting kon worden opgelegd aan naamloze vennootschappen die wel aandelen aan toonder uitgaven. De grootst mogelijke minderheid in de commissie stelde zich op het standpunt, dat de publikatieverplichting diende te worden opgelegd indien de akte van oprichting van de naamloze vennootschap uitgifte van toonderaandelen toeliet (afgezien van de vraag of die aandelen ook daadwerkelijk werden uitgegeven). De kleinst mogelijke meerderheid in de commissie huldigde een andere opvatting. Niet de mogelijkheid tot het al dan niet uitgeven van toonderaandelen diende het criterium tot de openbaarmakingsverplichting te zijn. Volgens hen diende de maatstaf te zijn of de naamloze vennootschap een beroep deed op het publieke vertrouwen (het beleggend publiek), hetgeen volgens deze leden samenhing met de vraag of de vennootschap ter beurze noteerde.

Een compromis bracht beide kampen uiteindelijk tot elkaar. Dit compromis leidde tot het art. 42c K (oud), hetwelk op 21 juli 1929 in werking trad.

Krachtens art. 42c K (oud) was het bestuur van de vennootschap verplicht binnen acht dagen na de vaststelling van de balans en de winst- en verliesrekening, volledige afschriften hiervan plus de toelichting daarop, voor een ieder ter inzage te leggen ten kantore van het handelsregister, indien:

"a. de akte van oprichting der naamlooze vennootschap uitgifte van aandeelen aan toonder tot een gezamenlijk hooger bedrag dan vijftig duizend gulden toelaat, dan wel van de naamlooze vennootschap hetzij aandelen aan toonder en certificaten aan toonder van aandeelen op naam, hezij aan zoodanige certificaten alleen een gezamenlijk hooger bedrag dan vijftig duizend gulden in omloop is; ;02

b. de naamlooze vennootschap schuldbrieven aan toonder uitstaande heeft, dan wel certificaten aan toonder van door haar uitgegeven schuldbrieven op naam in omloop zijn;

c. aandeelbewijzen of schuldbrieven der naamlooze vennootschap, of certificaten daarvan, opgenomen zijn in de prijscourant van eenige door Ons aan te wijzen, al dan niet op gezag van het plaatselijk bestuur gehouden, beurs; of

301 Belinfante 1929 , p. 343.

302 Deze grens was door de commissie vastgesteld op $f 100.000$, = zie Belinfante 1929, p. 339. 
d. het bedrijf der naamlooze vennootschap is of mede is het opnemen van gelden van derden, dan wel de naamlooze vennootschap het verzekeringsbedrijf uitoefent". ${ }^{3 / 3}$

Door de invoering van dit artikel werd in de wet een grens aangebracht tussen de openbare naamloze vennootschap en de besloten naamloze vennootschap. Het begrip besloten naamloze vennootschap werd door de wetgever - impliciet ingevoerd.

Naar opvatting van de wetgever bezat een vennootschap die een beroep deed op het beleggend publiek voor een bedrag groter dan vijftig duizend gulden een openbaar karakter en moest dientengevolge jaarlijks de in art. $42 \mathrm{c} \mathrm{K}$ (oud) genoemde bescheiden openbaar maken.

Een vennootschap die geen beroep deed op het beleggend publiek, althans geen beroep voor een bedrag groter dan vijftig duizend gulden, gold als besloten. Voor haar werd geen publikatieplicht ingevoerd. ${ }^{304}$

303 Belinfante 1929, p. 365.

304 Volmer definieert een besloten naamloze vennootschap als een "vennootschap, waarvan noch het kapitaal, bij eerste uitgifte of bij uitbreiding, noch leeningen bij openbare inschrijving zijn geplaatst en waarvan noch voor het kapitaal noch voor de obligatiën een open markt bestaat." Zie H.F.A. Volmer, Balanspublicatie van besloten- en familievennootschappen, NV 7 (1928), p. 132. 


\section{II.3 Aard van de beslotenheid van de - naamloze - vennootschap}

De naamloze vennootschap kende dus een aantal verschijningsvormen. Voor al deze vormen gold in beginsel eenzelfde wettelijk regime. Zo was daar de grote open - naamloze vennootschap. In het Verslag op het Gewijzigd Ontwerp Heemskerk treffen wij de volgende karakteristiek van zulk een naamloze vennootschap aan.

"naamlooze vennootschappen (...) die, economisch, zijn te beschouwen als zuivere kapitaalassociaties en die, ter verkrijging van haar aandeelen- of obligatienkapitaal, een beroep plegen te doen op de geldmarkt.(curs.JH) De aandeelen in naamlooze vennootschappen van dat type worden uitgegeven als verhandelbaar papier en gaan vervolgens ook als zodanig van hand tot hand. De deelneming in zulk een vennootschap draagt in den regel geen ander karakter dan dat van geldbelegging, althans is de gedachte van vennootschappelijke samenwerking daaraan vrijwel geheel vreemd." 305

Naast de grote - open - naamloze vennootschap valt te onderscheiden de familieof besloten naamloze vennootschap. Dit type naamloze vennootschap wordt, in het eerder genoemd Verslag, omschreven als een naamloze vennootschap:

"(...) waarin de personen der deelnemers zelf een zekere rol spelen. In de eerste plaats valt hier te denken aan vele maatschappijen, beoogende de voortzetting van een zaak, tot dusverre voor rekening van een of meer personen gedreven. De aanbieding van de gelegenheid tot deelneming in zulke maatschappijen wordt gewoonlijk beperkt tot den kring van familieleden of van goede bekenden, terwijl anderzijds ook dezen alleen bereid zijn hun geld in de zaak te steken, in vertrouwen op de hun bekende hoedanigheden der oprichtersbestuurders. (...) De deelnemers in deze soort vennootschappen zijn niet uitsluitend te beschouwen als bezitters van aandeelen bij wijze van geldbelegging, doch tevens als vennooten (curs. origineel), die steeds voeling blijven houden met den medevennootbestuurder der onderneming, lief en leed der zaak van nabij volgen en op de gestie den invloed uitoefenen, welke in verband met de feitelijke omstandigheden (...) hun bij de overeenkomst van oprichting is toegekend. Een aandeel in zulk een vennootschap is geenszins bestemd telkens van eigenaar te verwisselen; integendeel, in de vennootschap deelnemende is men er vrijwel zeker van, dat die deelneming zal zijn voor langen duur, en in vele gevallen zal zelfs de mogelijkheid niet bestaan zijn belang op een willekeurig tijdstip tegen behoorlijken prijs te gelde te maken. (curs.JH) ${ }^{306}$

305 Verslag van de commissie van voorbereiding uit de Tweede Kamer met de beantwoording door den Minister van Justitie, Belinfante 1929, p. 150.

306 Verslag van de commissie van voorbereiding uit de Tweede Kamer met de beantwoording door den Minister van Justitie, Belinfante 1929, p. 150. 
Als grondslag voor de beslotenheid kiest de wetgever van 1928 voor het feit of de naamloze vennootschap al dan niet een beroep doet op het publieke vertrouwen. Vreemd genoeg is deze grondslag voor de beslotenheid van de naamloze vennootschap een andere dan die voor de beslotenheid bij de, later in te voeren, besloten vennootschap. Niet de beperking van de vrije overdracht van aandelen vormde het criterium voor het zijn van een besloten samenwerkingsverband, maar de mogelijkheid tot het - in bepaalde mate - verhandelen van deze actiën ter beurze was bepalend voor het open danwel besloten karakter van de vennootschap. Schwarz ${ }^{307}$ merkt hieromtrent op:

"Uiterst interessant is dat de begrenzing tussen open en besloten vennootschap in de jaren '20 werd gezocht in (de mogelijkheid tot) uitgifte van toonderpapier en het voorstel nimmer is gelanceerd het kenmerk van de besloten vennootschap te zoeken in het feit of binnen die vennootschap de mogelijkheid tot vrije overdraagbaarheid der aandelen al dan niet statutair was beperkt, een kenmerk dat toch in de jaren " 70 als toetssteen voor de vraag of van een besloten samenwerkingsverband sprake is, wordt aangewezen."

Wat door Schwarz wordt betiteld als "uiterst interessant" komt mij eerder merkwaardig voor. Het voorstel de beslotenheid van het samenwerkingsverband te zoeken in de mogelijkheid tot beperking van de vrije overdracht van aandelen is inderdaad nimmer geopperd, terwijl de mogelijkheid tot beperking van die overdracht wel werd geboden. Art. 39a van het Gewijzigd Ontwerp Heemskerk bepaalt immers:

"De akte van oprichting kan de bevoegdheid tot vervreemding van aandelen op naam beperken. ${ }^{33 i s}$

Ook uit de eerder geciteerde karaktertrekken van de open en besloten naamloze vennootschap blijkt dat enkele parlementariërs de idee achter de beslotenheid van het samenwerkingsverband - op zijn minst - leken te zoeken in de beperkte

307 C.A. Schwar, diss. p. 29.

308 Later (Gewijzigd Ontwerp Donner) is de geciteerde zin van art. 39a komen te vervallen. Echter de mogelijkheid tot het beperken van de vrije overdracht van aandelen op naam bleef mogelijk. De akte van oprichting zal dus, omdat de wet het niet verbiedt, de bevoegdheid tot vervreemding van aandelen op naam kunnen beperken. Zie Belinfante 1929, p. 242 (noot 3). Voorts dienen de artt. $46 \mathrm{~b} \mathrm{~K}$ (oud) en $54 \mathrm{c} \mathrm{K}$ (oud) onder de aandacht te worden gebracht. In deze beide artikelen wordt aangegeven dat een naamloze vennootschap statutair (in de akte van oprichting) de uitgifte van aandelen aan toonder kan uitsluiten. Voor deze naamloze vennootschappen golden de bepalingen omtrent de geautoriseerde bijeenroeping van de algemene vergadering en de bepalingen inzake het enquêterecht niet, tenzij de statuten anders bepaalden. Voorts kon raadpleging en besluitvorming van en door aandeelhouders op een andere wijze geschieden dan in de algemene vergadering van aandeelhouders, ook hieromtrent konden de statuten anders bepalen. De grondslag voor de beslotenheid van het samenwerkingsverband wordt hier evenwel gezocht in het al dan niet doen van een beroep op het beleggend publiek. 
overdraagbaarheid der aandelen. ${ }^{309}$ Dit laatste werd echter door de wetgever van 1928 niet gezien als onderscheid tussen de open naamloze vennootschap en zijn besloten variant.

Overzien wij dit geheel dan komen we tot de volgende conclusie. Het in 1928 ingevoerde wettelijke regime voor de naamloze vennootschap bood onderdak aan een drietal verschillende varianten van de naamloze vennootschap.

In de eerste plaats was daar de open naamloze vennootschap. De vennootschap die beschouwd wordt als een zuivere kapitaalassociatie en die voor het verkrijgen van haar kapitaal een beroep doet op het beleggend publiek, waarbij zij de in art. $42 \mathrm{c} \mathrm{K}$ (oud) gestelde grens van vijftig duizend gulden overschrijdt.

Vervolgens signaleren we de besloten (of familie) naamloze vennootschap. Een samenwerkingsvorm dat eveneens een beroep kan doen op het beleggend publiek, echter slechts voor een bedrag hetwelk de limiet van vijftig duizend gulden niet te boven gaat. ${ }^{310}$

Ten slotte kan men binnen deze besloten naamloze vennootschap nog onderscheiden het samenwerkingsverband dat in het geheel geen beroep doet op buitenstaanders. De organisatie is statutair zo ingericht dat de kring van bij de vennootschap betrokken personen - in de loop der tijd - vrijwel niet, danwel bijzonder moeilijk, kan en zal veranderen. Bij deze vennootschappen treft men dan ook vrijwel uitsluitend op naam gestelde aandelen aan, welker overdracht statutair beperkt zal zijn.

Schwarz ${ }^{311}$ maakt in zijn dissertatie een onderscheid tussen de extern en de intern besloten naamloze vennootschap. Bij het extern besloten samenwerkingsverband ziet de beslotenheid op de bescherming van het beleggend publiek. Het intern besloten samenwerkingsverband karakteriseert hij als de vennootschap:

"welke met aanzien des persoons werd aangegaan, waarbinnen het vennootschappelijk samenwerkingsverband van aandeelhouders beschermd moest worden tegen penetratie door outsiders, althans door personen welke door de samenwerkende aandeelhouders niet als mede-aandeelhouder werden gewenst. Deze, door de aandeelhouders gewenste beslotenheid naar binnen toe, (...), trachtte men te waarborgen door blokkeringsbepalingen, waarbij de vrije overdraagbaarheid der aandelen werd ingeperkt, nog versterkt met een aanbiedingsver-

309 Hieruit mag men mijns inziens afleiden dat in de praktijk statutaire regelingen tot beperking van de vrije overdraagbaarheid van aandelen ter waarborging van het 'besloten karakter' van de vennootschap voorkwamen.

310 Deze vennootschapsvorn kan natururlijk de wettelijke grens van $f 50.000,=$ overschrijden. Het gevolg hiervan is dat zij verplicht wordt de in art. $42 \mathrm{c} \mathrm{K}$ (oud) genoemde bescheiden openbaar te maken. Het belangrijkste verschil tussen de open en de besloten naamloze vennootschap is dus de publikatieplicht. Andere verschillen tussen beide rechtsvormen vinden wij in de artt. $46 \mathrm{~b}$ jo. $43 \mathrm{c}-\mathrm{d} \mathrm{K}$ (oud) en de artt. 54c jo 53d, 54a en 54b K (oud). Zie ook P. Sanders, Open en besloten N.V., NV 43 (1965), p. 53.

311 Zie C.A. Schwarz, diss. p. 36-37. 
plichting (...), waandoor bijv. voorkomen kon worden dat door vererving van aandelen een ongewenste buitenstaander blijvend aandeelhouder werd."

Samenvattend kan worden gesteld dat tot 1971 de naamloze vennootschap de enige kapitaalvennootschap in de Nederlandse wetgeving was. Met de invoering van de publikatieplicht voor grote naamloze vennootschappen bood de wetgever stilzwijgend - de mogelijkheid om met een, van de naamloze vennootschap afgeleide, besloten of familie naamloze vennootschap deel te nemen aan het maatschappelijk verkeer. Uit deze laatste categorie ontstond een rechtsvorm die qua inrichting significante overeenkomsten vertoonde met de huidige besloten vennootschap met beperkte aansprakelijkheid. Het ontstaan van deze besloten variant hing nauw samen met de voor de grote naamloze vennootschap ingevoerde publikatieplicht van de jaarstukken. De wetgever ontsloeg bepaalde naamloze vennootschappen van deze publikatieverplichting indien zij voldeden aan bepaalde vereisten. De vraag of en wanneer een naamloze vennootschap gekenschetst diende te worden als besloten hing dus af van de vraag of de vennootschap een beroep deed op het beleggend publiek c.q. of de aandelen van de vennootschap ter beurze waren genoteerd. De wetgever zag zich niet genoodzaakt voor de besloten variant van de naamloze vennootschap een aparte rechtsvorm te scheppen. Ook in de literatuur bestond geen direct verlangen naar een nieuwe rechtsvorm. ${ }^{312}$

Het algemene gevoelen, dat de bestaande toestand, waarin een regeling voor de naamloze vennootschap met daarbinnen twee verschillende verschijningsvormen, een ideale situatie vormde, verandert in de jaren ' 60 . Debet aan deze verandering was een tweetal gebeurtenissen. In de eerste plaats was daar het rapport van de Commissie Verdam tot herziening van het ondernemingsrecht. Dit rapport stelde met name een verandering voor van de publikatieplicht geregeld in art. 42c K (oud). In het voorstel van de Commissie Verdam was een naamloze vennootschap

312 W.C.L. van der Grinten, Is het wenselijk voor de zogenaamde besloten naamloze vennootschap in de civielrechtelijke wetgeving bijzondere voorzieningen te treffen, al dan niet met invoering van een afzonderlijke rechtsvorm?, Handelingen der Nederlandse Juristen Vereniging, 1953, Deel I, p. 97. Van der Grinten schrijf: "Ons geldend n.v.-recht houdt geen bepalingen in, die voor de besloten vennootschap beter ongeschreven hadden kunnen blijven. Aan een bevredigende inrichting van de besloten vennootschap staat ons n.v.-recht niet in de weg. Wellicht mag men zelfs poneren, dat ons n.v.-recht veelmeer is ingesteld op de besloten dan op de open vennootschap. Betekent dit nu, dat een afzonderlijke rechtsvorm voor de besloten vennootschap voor ons recht volkomen verwerpelijk is? Deze conclusie ware voorbarig." Aan het einde van het door Van der Grinten geschreven preadvies voor de NJV concludeert hij: "Ons n.v.-recht heeft een eigen karakter. Het verschilt in niet onbelangrijke mate met dat van de ons omringende landen. Ons n.v.-recht is dat van de bedachtzame, vrijheidslievende Hollandse koopman. Zolang wij trots zijn op onze nationale deugden en ondeugden in de handel, zou ik willen bepleiten ons eigen n.v.-recht te blijven behouden." 
verplicht haar balans plus winst- en verliesrekening met de toelichting daarop en de verplicht gestelde accountantsverklaring bij het handelsregister te deponeren, indien de naamloze vennootschap aandelen aan toonder heeft geplaatst tot een bedrag van tenminste $f 250.000$, =, of tot dat bedrag certificaten aan toonder van aandelen op naam in omloop zijn, danwel aan aandelen aan toonder en certificaten aan toonder van aandelen op naam tezamen een bedrag van tenminste $f 250.000,=$ in omloop is. Het valt op dat de eerder gestelde grens van $f 50.000,=$ wordt opgetrokken naar $f 250.000,=$. Hiermee wordt het verschil tussen het zijn van een open- danwel besloten naamloze vennootschap wel erg in het oog springend. Sanders pleit dan ook krachtig voor het opnemen van de begrippen open- en besloten naamloze vennootschap in de wettelijke regeling.

\footnotetext{
"Wanneer ik ten slotte tot ons nationale terrein mag terugkeren, dan meen ik ook, zuiver nationaal bezien, (dat; $\mathrm{JH})$ er redenen genoeg zijn aan te voeren om het maken van een onderscheid, ook in de wet, te overwegen. De ter beurze genoteerde n.v. is nu eenmaal iets anders dan de n.v. waarin de kleine middenstander zijn zaak omzet. Wanneer wij in het algemeen over de n.v. spreken dreigt steeds verwarring. De economische realiteit toont ons nu eenmaal grote verschillen. Wanneer de wetgever daaraan tot op zekere hoogte en zonder in perfectionisme te vervallen vorm zou weten te geven, door althans tussen de besloten en de open n.v. een duidelijk onderscheid te maken en daarbij voor beide typen de grote soepelheid, welke tot nu toe onze wetgeving op dit gebied kenmerkte, zou weten te bewaren, zou dit mijns inziens ook zuiver nationaal gezien winst kunnen opleveren. ${ }^{\text {.313 }}$
}

Naast deze nationale ontwikkelingen zijn er ook ontwikkelingen bespeurbaar op het internationale vlak. Voor de opvatting dat in het Nederlandse recht een duidelijk onderscheid gemaakt dient te worden tussen de open en de besloten naamloze vennootschap is dan ook een tweede oorzaak aan te geven.

313 P. Sanders, NV 43 (1965), p. 55. 



\section{II.4 De Eerste EG-richtlijn en de besloten vennootschap met beperkte aansprakelijkheid}

Op 9 maart 1968 werd de Eerste richtlijn van de Raad van de Europese Gemeenschappen tot harmonisatie van het Vennootschapsrecht vastgesteld. De strekking van deze richtlijn was het coördineren van de waarborgen, welke in de Lid-Staten worden verlangd van de vennootschappen in de zin van de tweede alinea van art. 58 van het Verdrag, om de belangen te beschermen zowel van de deelnemers in deze vennootschappen als van derden, zulks ten einde die waarborgen gelijkwaardig te maken. ${ }^{314}$

"De door deze richtlijn voorgeschreven coördinatiemaatregelen zijn van toepassing op de wettelijke en bestuursrechtelijke voorschriften van de Lid-Staten die betrekking hebben op vennootschappen van de volgende rechtsvorm: (...) de naamloze vennootschap, de commanditaire vennootschap op aandelen; $(. . .)^{m 315}$

In tegenstelling tot de naamloze vennootschap (en de commanditaire vennootschap op aandelen ${ }^{316}$ ) behoefde de besloten naamloze vennootschap ${ }^{317}-$ nog - niet te

314 Publicatieblad van de Europese gemeenschappen nr. 165, 14-03-1968 (68/151/EEG). De richtijn stelt zich tot doel het coördineren van de nationale bepalingen betreffende de openbaarmaking, de rechtsgeldigheid van de verbintenissen en de nietigheid van vennootschappen; dit is namelijk van belang met het oog op de bescherming van de belangen van derden.

315 Art. 1 Eerste EG-richtijn.

316 In het vervolg van dit betoog zal geen rekening worden gehouden met deze rechtsvorm gezien het feit dat de commanditaire vennootschap op aandelen bij wet van 28 mei 1975, Stb. 277 uit het Nederlandse rechtssysteem werd geschrapt.

317 In het tweede lid van art. 2 van de richtlijn lezen we:

"Voor de toepassing van het eerste lid onder $f$ worden als besloten naamloze vennootschappen beschouwd die naamloze vennootschappen welke voldoen aan de volgende voorwaarden:

a. zij kunnen geen aandelen aan toonder uitgeven;

b. geen "certificaat aan toonder van aandelen op naam" in de zin van art. $42 \mathrm{c}$ (oud; JH) van het Nederlands Wetboek van Koophandel, kan door wie dan ook in omloop worden gebracht;

c. de aandelen kunnen niet ter beurze worden genoteerd;

d. in de statuten wordt een bepaling opgenomen volgens welke de vennootschap haar goedkeuring moet verlenen voor iedere overdracht van aandelen aan derden, met uitzondering van de overgang ten gevolge van overlijden en, indien de statuten hierin voorzien, met uitzondering van overgang op de echtgenoot en op verwanten in opgaande en nederdalende lijn; de overdracht moet, met uitsluiting van elke blanco overdracht, plaatsvinden, hetzij bij onderhandse akte, getekend door hem die overdraagt en door de verkrijger, hetzij door authentieke akte;

e. het karakter van besloten naamloze vennootschap blijkt uit de statuten; in de naam van de vennootschap komen de woorden "Besloten Naamloze Vennootschap" of de afkorting "B.N.V." voor." Zie voor een voorstel tot aanpassing van de richtlijn, C.A. Schwarz, "Private" as in 
voldoen aan de publikatieplicht van balans en winst- en verliesrekening. Zoals reeds eerder werd opgemerkt kende de Nederlandse wetgeving geen omschrijving van de besloten naamloze vennootschap.

Naar aanleiding van de Eerste richtlijn van de Raad van de Europese Gemeenschap ter Harmonisatie van het Vennootschapsrecht van 9 maart 1968 werd in ons land een wetsontwerp aanhangig gemaakt dat zag op de invoering van een nieuwe rechtspersoonsvorm in het Nederlandse recht. ${ }^{318}$ Op advies van de door de Minister ingestelde Commissie Vennootschapsrecht ${ }^{319}$ werd gekozen voor het maken van een onderscheid tussen twee kapitaalvennootschappen. Een afzonderlijke rechtsvorm diende te worden ingevoerd voor het besloten samenwerkingsverband van aandeelhouders. In de MvT lezen wij:

"De vraag rijst of niet aan een ander stelsel de voorkeur moet worden gegeven. Dit andere stelsel zou dan moeten zijn, dat naamloze vennootschap en besloten vennootschap tot twee onderscheiden rechtsvormen worden gemaakt. Op deze wijze wordt bereikt, dat de eenheid van de regeling van de naamloze vennootschap gehandhaafd blijft en dat voor de besloten vennootschapsvorm een eigen aan deze figuur aangepaste rechtsvorm wordt gegeven. (...) Aldus verkrijgt de Nederlandse wetgeving nimte om de structuur van de besloten vennootschap naar eigen inzicht te bepalen. ${ }^{n 320}$

$317 \rightarrow$

Private Companies, in: 'The European Private Company?', H.J. de Kluiver, W. van Gerven (eds.), 1995 , p. 227.

De besloten naamloze vennootschap naar Brussels model kende dus een tweeledige beslotenheid. De bepalingen van art. 2 lid 2 onder a-c van de richtlijn zien op een, ons bekende, beslotenheid ten opzichte van het beleggend publiek: geen aandelen aan toonder, geen certificaten aan toonder van op naam gestelde aandelen en geen notering ter beurze. Het beding opgenomen onder punt d van genoemd artikel ziet op een andere beslotenheid. Een beslotenheid naar binnen toe. Statutair dient te worden bepaald dat de vennootschap haar goedkeuring dient te verlenen aan iedere overdracht van aandelen in haar kapitaal. Voor de Nederlandse wetgeving min of meer een nieuw aspect (De wet van 1928 opende weliswaar de mogelijkheid om de overdracht van aandelen statutair te beperken, maar stelde deze niet verplicht; zie art. $39 \mathrm{a} \mathrm{K}$ (oud)). Uitzondering wordt gemaakt voor de overgang van aandelen ten gevolge van overlijden van de aandeelhouder.

318 TK 10689 , nrs. 1 en 2.

319 Ingesteld 9 juli 1968, Stcr. 138, 18 juli 1968.

320 "Een voordeel van dit stelsel is ook, dat hiermede een verschil tussen de Nederlandse wetgeving en die van alle andere E.E.G.-staten wordt opgeheven. Deze staten kennen een aparte rechtsvorm voor de besloten vennootschap. In verband met de verdere rechtsontwikkeling in de E.E.G. is het van belang. dat Nederland zich aan elders bestaande rechtssituaties conformeert. Te verwachten valt, dat verdere E.E.G.-richtlijnen voor het vennootschapsrecht tot stand zullen komen, waarbij uiteenlopende regels zullen worden gegeven voor het N.V.- en B.V.-type." aldus de Commissie Vennootschapsrecht, TK 10 689, Bijlage MvT nr. 4, p. 21. Op deze plaats ga ik niet in op de parlementaire behandeling van het wetsvoorstel tot invoering van de besloten vennootschap. Ik zal mij met name beperken tot het besloten karakter van de BV. 
Het eigen inzicht, volgens welke de wetgever de regeling van de besloten vennootschap inrichtte, wordt gekenmerkt door de wijze van overdracht van de aandelen in het kapitaal van de besloten vennootschap. In de MvT wordt hieromtrent opgemerkt:

\begin{abstract}
"Naamloze vennootschap en besloten vennootschap vertonen een vrij grote mate van verwantschap. Het belangrijkste verschil is gelegen in de regeling omtrent de overdracht van aandelen. Het ontwerp stelt voorop, dat overdracht van aandelen in een besloten vennootschap slechts kan geschieden met goedkeuring van de algemene vergadering van aandeelhouders of van een ander orgaan van de vennootschap. Bepaalde overdrachten worden vrij gelaten, behoudens andere statutaire regeling. Echter staat bet belanghebbenden vrij de aandelen op andere wijze te blokkeren en wel in dier voege, dat de aandeelhouder die aandelen wil vervreemden, deze eerst moet aanbieden aan zijn mede-aandeelhouders, c.q. aan personen die door de vennootschap daantoe worden aangewezen. Het is duidelijk dat het besloten karakier van de vennootschap wordt geaccentueerd. (curs; JH) ${ }^{\mathrm{n} 32 !}$
\end{abstract}

De beslotenheid van de vennootschap diende aldus tot uitdrukking te komen in de wettelijk verplicht gestelde beperking van de overdracht van aandelen. Hiertoe schreef de wetgever dwingendrechtelijk een blokkeringsregeling voor. De verplichte blokkering kwam tot uiting in art. $57 / \mathrm{K}$ (oud) waarin werd voorgeschreven dat voor iedere overdracht van aandelen, behalve wanneer die binnen de wettelijk vastgestelde vrije kring plaatsvond, goedkeuring was vereist van de algemene vergadering van aandeelhouders of van een ander bij de statuten aangewezen orgaan van de vennootschap. ${ }^{322}$

Duidelijk zien wij hier het verschil betreffende de invulling van het begrip beslotenheid van de vennootschap. Bescherming van het beleggend publiek (bij de naamloze besloten vennootschap) versus bescherming van de aandeelhouders tegen indringers van buiten (bij de besloten vennootschap).

Zoals reeds eerder gezegd kan in de huidige wetgeving een onderscheid gemaakt worden tussen de twee rechtsvormen voor kapitaalvennootschappen. Aan de ene zijde de naamloze vennootschap, veelal gebruikt door grote ondernemingen die ter verkrijging van hun kapitaal een beroep doen op het beleggend publiek. Aan de andere zijde de besloten vennootschap. De rechtsvorm voor de kleine(re) samenwerkingsverbanden die geen behoefte hebben aan investeringen in hun onderneming door buitenstaanders. Sterker, in beginsel staat de verplichte blokkering van de aandelen in het kapitaal van de besloten vennootschap een beroep, op ruime schaal, op risicodragend vermogen in de weg. In de praktijk zijn echter vele varianten van beide rechtsvormen ontstaan. Een ieder die met een onderneming wenst deel te nemen aan het maatschappelijk verkeer zal op zoek gaan naar een rechtsvorm die het meest beantwoordt aan zijn bedoelingen. Hij zal

321 J.M.M. Maeijer, Wetsgeschiedenis, p. IXc-18.

322 Zie omtrent blokkering van aandelen uitgebreid C.A. Schwarz, diss. 
de organisatie van zijn rechtsvorm naar zijn wens trachten in te richten. Men kan dus niet spreken van één type naamloze vennootschap en één type besloten vennootschap.

Een naamloze vennootschap behoeft niet per se een open karakter te bezitten. Haar organisatie kan gelijk die van een besloten vennootschap worden ingericht. Statutair kan bepaald zijn dat zij slechts aandelen op naam mag uitgeven. Deze aandelen kunnen geblokkeerd worden en er kunnen kwaliteitseisen verbonden worden aan het aandeelhouderschap. Naast deze volledig besloten naamloze vennootschap komen in de praktijk veelvuldig naamloze vennootschappen voor die in beginsel open zijn, en eventueel ter beurze noteren, maar in de organisatie besloten kernen kennen. Men denke hierbij vooral aan de grote beursgenoteerde vennootschappen, die naast gewone aandelen aan toonder, preferente beschermingsaandelen hebben geplaatst. Ook kan men denken aan vennootschappen die een bepaalde mate van zeggenschap hebben geconcentreerd bij de houders van prioriteitsaandelen. Voorts denke men aan een naamloze vennootschap die statutair voorzien is van een $1 \%$-regeling, die niet geldt voor het administratiekantoor, en die aandelen op naam heeft uitgegeven aan een stichting administratiekantoor, welke stichting van deze aandelen royeerbare certificaten laat noteren op de beurs. ${ }^{323}$

Een besloten vennootschap daarentegen kan, in theorie, niet als een open vennootschap ingericht worden. Immers, de wet bepaalt dwingendrechtelijk dat de overdracht van aandelen in een besloten vennootschap steeds statutair dient te worden beperkt. Dit betekent evenwel niet dat deze statutaire bepaling in de praktijk een onoverkomelijke blokkade opwerpt tegen een vrije overdracht van aandelen. Aandeelhouders kunnen - incidenteel - met elkaar overeenkomen dat, in geval de blokkeringsregeling bestaat uit een goedkeuringsblokkade, voor de overdracht goedkeuring wordt verleend of dat, in geval van een statutaire aanbiedingsblokkade, niet op de aandelen zal worden gereflecteerd door zittende aandeelhouders. ${ }^{324}$ Op deze wijze kan ook de besloten vennootschap, praktisch gezien, een 'open' karakter hebben.

323 Zie omtrent deze problematiek C.A. Schwarz, Versterking van het beschermend effect van certificering van aandelen, WPNR 6104 (1993), p. 617 e.v.

324 Zie omtrent de relatie blokkeringsregelingen en stemovereenkomsten $B$. Wachter, Blokkeringsclausules en stemrecht, in: 'Verzekeringen van vriendschap' (Dorhout Mees-bundel), 1974, p. 231 e.v.; m.n. p. 239-240. Zie ook J.M.M. Maeijer, De stemovereenkomst van aandeelhouders, in: 'Recht zo die gaat' (P.W. van der Ploeg-bundel), 1976, p. 95 e.v. Algemeen over stemovereenkomsten A.M. Brenninkmeijer, Stemovereenkomsten van aandeelhouders: de gebondenheid aan stemovereenkomsten, tegen de achtergrond van het Franse en Duitse vennootschapsrecht, diss. Zie voor een bloemlezing van opvattingen van Nederlandse juristen en rechterlijke uitspraken betreffende de geoorloofdheid van stemovereenkomsten A.L. Mohr; Spijkers, Ondernemingsrecht op de breuklijn van praktijk en wetenschap, rede, 1993. Zie verder $H$.J. de Kluiver, Joint ventures en stemovereenkomsten. Een rechtsvergelijkend perspectief, A.Ae 44 (1995) 5, p. 104 e.v. 
Alvorens in te gaan op de vragen naar de gevolgen van verpanding van aandelen en de relatie tussen verpanding en beslotenheid, nog enkele overwegingen ten aanzien van de dwingendrechtelijke blokkering van aandelen.

De op 9 maart 1968 vastgestelde Europese richtlijn zag - onder andere - op de invoering van een verplichte openbaarmaking van enkele financiële- en beleidsstukken van, voor wat Nederland betreft, naamloze vennootschappen. Van deze publikatieplicht werden de besloten naamloze vennootschappen vrijgesteld. ${ }^{325}$ In het systeem van de richtlijn kon een naamloze vennootschap door middel van twee varianten deel nemen aan het maatschappelijk- en rechtsverkeer, ten eerste in de vorm van de gewone, open naamloze vennootschap, ten tweede als een besloten variant daarvan. In tegenstelling tot hetgeen de richtlijn doet vermoe$\operatorname{den}^{326}$, kende de Nederlandse wet, anders dan de rechtspraktijk, het instituut besloten naamloze vennootschap niet. ${ }^{327}$ Er moest dus in de Nederlandse wetgeving op de een of andere manier een oplossing worden gezocht voor dit probleem. Er kwam een oplossing waarbij werd afgeweken van de in de richtlijn geboden uitweg. Niet gekozen werd voor het voorstel van Sanders om in art. 42c $\mathrm{K}$ (oud) te volstaan met het wettelijk "labellen" van de open en besloten naamloze vennootschap. ${ }^{328}$ Kritiek op dit voorstel kwam van de zijde van Maeijer ${ }^{329}$ :

"Is er aldus door de ontwikkelingen op het Europese vlak reeds voldoende aanleiding om het scheppen van een eigen rechtsfiguur voor de vennootschap met beperkte aansprakelijkheid emstig te overwegen, ik meen dat er ook nationaal bezien, gewichtige redenen zijn die hiertoe nopen. En daarbij zou ik bepaald verder willen gaan dan Sanders in 1965, wiens voorstel - materieelrechtelijk gezien - eigenlijk alles bij het oude liet en enkel beoogde om in een aangepast art. 42c W.v.K. de naambordjes 'open' en 'besloten' op te hangen.

De economische en sociale realiteit van de publieke ter beurze genoteerde n.v. is een andere dan die van de besloten familie-n.v. Dit wezenlijke verschil behoort naar mijn overtuiging zijn weerslag te vinden in een voor ieder type speciaal gemodelleerd wettelijk regime."

325 Zie art. 2 lid 1 sub f van de Eerste EG-richtlijn. Het tweede lid van art. 2 geeft, zoals we reeds eerder zagen, aan wat volgens de richtlijn onder een besloten naamloze vennootschap wordt verstaan. Een naamloze vennootschap wordt als besloten gezien wanneer zij geen aandelen aan toonder uitgeeft, geen certificaten van aandelen aan toonder in omloop brengt, haar aandelen niet ter beurze noteren, haar statuten een goedkeuringsblokkade kennen voor de overdracht van aandelen aan derden buiten de gedefinieerde vrije kring en haar staruten blijk moeten geven van het karakter van besloten naamloze vennootschap (voorts dient in de naam van de vennootschap naar voren te komen dat het gaat om een besloten naamloze vennootschap).

326 In art. 2 lid 1 sub f wordt immers expliciet gesproken over een besloten naamloze vennootschap naar Nederlands recht.

327 Zie ook H.J. de Kluiver, The European Private Company? A Dutch Perspective, in: 'The European Private Company?' eds. H.J. de Kluiver, W. van Gerven, 1995, p. 109.

328 P. Sanders, NV 43 (1965), p. 54.

329 J.M.M. Maeijer, NV 46 (1968), p. 28. 
De Nederlandse wetgever koos voor een nieuwe rechtsvorm die op enkele punten afweek van de regeling van de bestaande naamloze vennootschap. ${ }^{330}$

Wilde de nieuw gecreëerde rechtsvorm ontspringen aan de verplichte publikatie van jaarstukken dan diende zij een niet-naamloos karakter te bezitten. ${ }^{331}$ Zoals eerder opgemerkt, zocht de wetgever de beslotenheid in de beperking van de overdraagbaarheid van de aandelen van de besloten vennootschap, de dwingendrechtelijk voorgeschreven blokkering van aandelen. De wetgever zag er bij wege van dwingend recht op toe dat het door enkele personen aangegane samenwerkingsverband ook werkelijk een streng besloten karakter kende en zou behouden. De aandeelhouders werden als het ware verplicht beschermd tegen invloed van buiten. De vraag of deze actie van de wetgever geldt als de meest geschikte betwijfel ik ten zeerste. De wetgever gebruikt de verplichte blokkering van aandelen om een onderscheid aan te brengen tussen de naamloze en de besloten vennootschap. Meer specifiek om ervoor te zorgen dat de besloten vennootschap niet viel onder de verplichte openbaarmaking der jaarstukken. Als argument gold wellicht dat wanneer een samenwerkingsverband niet wenst dat haar financiële gegevens voor een ieder kenbaar worden of zijn, zij het juk van de verplichte blokkering dient te tolereren.

De vraag naar de legitimering van de wettelijke blokkade dringt nog meer nu in 1984, naar aanleiding van de Aanpassingswet Vierde EG-richtlijn, de besloten vennootschap werd onderworpen aan eenzelfde plicht tot openbaarmaking van de jaarstukken als de naamloze vennootschap. Het voordeel dat de besloten vennootschap jaren had geboden verviel, de verplichte blokkering bleef. Heeft de wetgever hier geen steek laten vallen? Mijns inziens wel. Welk valide argument is aan te dragen voor het handhaven van de wettelijk verplichte blokkade van aandelen? Het feit dat de wettelijk voorgeschreven blokkering van aandelen puur en alleen gebruikt zou worden als kenmerk van de besloten vennootschap ter onderscheiding van de naamloze vennootschap zou ik met kracht willen bestrijden. Immers, de wettelijke regeling biedt voldoende andere aspecten waardoor een besloten vennootschap zich kan onderscheiden van de naamloze vennootschap. Schwarz neemt ten aanzien van deze materie een duidelijk standpunt in. Hij stelt ${ }^{332}$ :

330 De belangrijkste punten van verschil tussen de regeling van de naamloze vennootschap en die der besloten vennootschap waren: de wijze van overdracht van aandelen op naam; de publikatieplicht van de jaarstukken van de naamloze vennootschap en de mogelijkheid tot ontbinding van de vennootschap door de rechter op, een op gewichtige redenen gebaseend, verzoek van een belangrijke minderheid van de aandeelhouders.

331 Zie ook art. 13 Eerste EG-richtlijn: "De in art. 2, lid 1, sub $f$ (curs.origineel), opgelegde verplichting tot openbaarmaking treedt voor andere naamloze vennootschappen naar Nederlands recht dan die bedoeld in het eerste lid van art. $42 c$ (curs.origineel) van het Nederlandse Wetboek van Koophandel, eerst in werking dertig maanden na de kennisgeving van deze richtijn."

332 C.A. Schwar, diss. p. 60-61. 
"(...) bij de invoering van de gelijke publikatieplicht voor besloten en naamloze vennootschap is in ieder geval iedere bestaansgrond voor dit wettelijke voorschrift komen te vervallen. Ook in die afwijkende visie moet immers geconcludeerd worden dat, nu binnen besloten vennootschappen het 'voordeel' van het ontbreken van de publikatieplicht verdwenen is, er geen redenen aanwijsbaar zijn het 'nadeel' van de niet-vrije overdraagbaarheid van aandelen te laten voortbestaan.

Conclusie is dat de wettelijke verplichting tot het statutair beperken van de vrije overdraagbaarheid van aandelen in besloten vennootschappen, zoals vervat in art. 2:195 BW, dient te worden geschrapt. ${ }^{\text {"333 }}$

Mijns inziens is de conclusie die door Schwarz verbonden wordt aan het invoeren van de publikatieplicht voor de besloten vennootschap de meest voor de hand liggende. Maeijer ${ }^{334}$ deelt Schwarz' opvatting niet. Hij is van mening dat het betoog van Schwarz, dat de wetgever blokkering van aandelen niet voorschreef ter bescherming tegen inmenging in het interne samenwerkingsverband, door Schwarz aangeduid als bescherming van de 'interne beslotenheid', maar als bescherming van de belegger tegen de niet publicerende vennootschap, de zogenaamde 'externe beslotenheid', ${ }^{335}$ onvoldoende steun vindt in de wetsgeschiedenis. Hij verwijst naar een citaat uit de MvA bij het Ontwerp van Wet 10 689 betreffende de 'Regeling van de besloten vennootschap met beperkte aansprakelijkheid' en geeft aan dat het bij de besloten vennootschap niet alleen ging om het uitsluiten van een beroep op de kapitaalmarkt, maar dat de regeling van - het huidige - art. $195 \mathrm{BW}$, in de ogen van de wetgever, tevens zag op de uit te oefenen invloed van een orgaan van de vennootschap op de keuze van nieuwe aandeelhouders. Maeijer merkt voorts op:

\footnotetext{
"Uit de MvA blijkt voorts dat net zo als bij de emissie van aandelen, ook bij het bewaken van het besloten karakter van de vennootschap essentieel is: dat steeds een besluit van een orgaan van de vennootschap noodzakelijk is. Of dit orgaan de algemene vergadering is dan wel een ander orgaan, wordt in beide gevallen aan de stasusen overgelaten. (curs.JH)"
}

Geeft Maeijer, onder verwijzing naar de MvA, ondanks zijn kritiek op de zienswijze van Schwarz, niet eveneens aan dat de stelling 'de besloten vennootschap is zo besloten als zij is' juist is? Aan de statuten van de besloten vennootschap, dus aan de oprichters/aandeelhouders, wordt overgelaten te bepalen welk orgaan beslist over de toelating van nieuwe leden tot het samenwerkingsverband. Dit kan dus de algemene vergadering van aandeelhouders zijn, in het geval waarin sprake is van een echt 'intern' besloten samenwerkingsverband. Het kan echter evenzo het bestuur of de raad van commissarissen zijn. Naar mijn mening kan men zelfs niet spreken van een blokkering in de eigenlijke zin van het woord

333 Instemmend $P$. van Schilfgaarde, van de BV en de NV, $10^{\circ}$ druk, nr. 35.

334 Asser-Maeijer-2-III, nr. 210.

335 Zie omtrent de termen 'interne' en 'exteme' beslotenheid C.A. Schwar, diss. p. 52 e.v. 
wanneer de raad van commissarissen het goedkeurende orgaan is in het kader van een blokkeringsregeling. Deze is dan, mijns inziens, eerder te beschouwen als een beschermingsconstructie. In het geval waarin niet de algemene vergadering van aandeelhouders maar een ander vennootschapsorgaan statutair als goedkeurend orgaan is aangewezen, kan men naar mijn mening vraagtekens plaatsen bij het waarborgen van - de ratio van - het 'besloten' karakter van het samenwerkingsverband. Niet de 'leden' van het besloten samenwerkingsverband, maar 'vreemden' beslissen over het al dan niet toelaten van derden tot de kring van aandeelhouders. Vormt dit geen reden te meer om te bepleiten dat de regeling van art. $195 \mathrm{BW}$ facultatief zou moeten worden? Laat de 'leden' van de vennootschap beslissen of hun samenwerkingsverband - binnen de grenzen van de wet open danwel besloten is. Waarom aandeelhouders wettelijk verplichten de overdraagbaarheid van hun aandelen aan strikte beperkingen te onderwerpen, nu het voordeel van de ratio, namelijk het beschermen van het beleggend publiek bij de niet publicerende vennootschap, van de besloten vennootschap geheel is komen te vervallen? Is het niet beter de Nederlandse wetgeving op dit punt aan te passen, in die zin dat de wettelijk verplichte blokkade wordt geschrapt en daarvoor in de plaats een facultatieve regeling op te nemen? Men kan dan denken aan het voorbeeld dat de Duitse wetgever ons biedt. ${ }^{336}$

Bij gelijke publikatieverplichtingen voor naamloze en besloten vennootschappen, dient de wetgever aandeelhouders vrij te laten hun samenwerkingsvorm naar eigen wens in te richten. ${ }^{337}$

336 In lid 5 van $\$ 15$ GmbHG wordt ten aanzien van de overdracht van aandelen in een Gesellschaft mit beschränkter Haftung bepaald: "Durch den Gesellschaftsvertrag kann die Abtretung der Gesellschaftsanteile an weitere Voraussetzungen geknüpft werden, insbesondere von der Genehmigung der Gesellschaft abhängig gemacht werden." De Duitse wetgever heeft dus niet gekozen voor een verplichte blokkade van aandelen. Statutair kunnen aan de overdracht van aandelen nadere verplichtingen en vereisten worden gesteld.

337 Zo was ook de praktijk voor 1972 . Wilde personen samenwerken in een kleine, vastomlijnde en niet of weinig veranderende kring van aandeelhouders dan blokkeerden zij hun aandelen door middel van een bepaling in de statuten. Wilden zij dit niet dan werd gekozen voor een grote, dan wel kleine open naamloze vennootschap met aandelen aan toonder die al of niet ter beurze noteerden of in de toekomst wellicht zouden noteren. Zie in gelijke zin C.A. Schwar, Overdracht van aandeelhouderschap en art. 195 Boek 2 BW, NV 61 (1983), p. 223. 


\section{II.5 Verschijningsvormen van kapitaalvennootschappen}

Zoals werd opgemerkt kent ons positieve recht twee vormen kapitaalvennootschappen, de naamloze vennootschap en de besloten vennootschap. Binnen deze twee vormen kunnen zich - binnen de grenzen door wet en statuten getrokken een aantal variaties ontplooien. De revue passerend treft men aan: de internbesloten vennootschap, de niet intern-besloten vennootschap, de open naamloze vennootschap, de intern-besloten naamloze vennootschap en de naamloze vennootschap met een 'gemengd karakter'. ${ }^{338}$

\section{a. De intern-besloten vennootschap}

Het samenwerkingsverband dat met aanzien des persoons is aangegaan en dat, met de door de wet geboden middelen, haar besloten karakter tegen de invloed van buitenstaanders wenst te beschermen, karakteriseren we als de intern-besloten vennootschap. ${ }^{339}$ De statuten van deze rechtspersoon zullen een aanbiedingsblokkade bevatten, versterkt met een aanvullende goedkeuringsregeling (met de algemene vergadering van aandeelhouders als goedkeurend orgaan) of omgekeerd, zullen geen vrije kring kennen, zullen de mogelijkheid tot verpanding van aandelen uitgesloten danwel sterk beperkt hebben en zullen een erfrechtelijke blokkade bevatten. Voorts zal de mogelijkheid van volmachtverlening, tussen aandeelhouders onderling en tussen aandeelhouders en derden, betrekkelijk het uitoefenen van het stemrecht verbonden aan de aandelen beperkt zijn, en wel in die zin dat het verlenen van een incidentele volmacht, onder omstandigheden, toelaatbaar kan zijn maar het verlenen van een doorlopende volmacht te allen tijde uitgesloten is. Kortom, de intern-besloten vennootschap heeft het kenmerk van een intuitu personae aangegaan samenwerkingsverband van aandeelhouders, waarbinnen de aandeelhouders zoveel mogelijk de samenstelling van het verband zullen bepalen.

338 Zie F.J.P. van den Ingh, De medewerkingseis van art. 3.9.3.1. INBW, (I), WPNR 5943 (1989), p. $627-628$.

339 Zie C.A. Schwar, 'Ach, eindeloos getob', Over toelating van de echtgenoot van de aandeelhouder tot het stemrecht op aandelen, NJB 1994, p. 1069 (lk). 


\section{b. De niet intern-besloten vennootschap}

Zo kan het samenwerkingsverband gekenschetst worden waarbinnen geen of minder behoefte bestaat aan het weren van inmenging van buitenaf. ${ }^{340}$ In beginsel zullen de statuten van deze vennootschap een - binnen de grenzen van het positieve recht passend - liberaler karakter hebben dan die van de intern-besloten vennootschap. Liberaler in die zin dat de statuten een uitgebreide vrije kring kennen waarbinnen de aandelen zonder inachtneming van de blokkeringsregeling kunnen worden overgedragen, een goedkeuringsblokkade kennen met een andere instantie dan de algemene vergadering van aandeelhouders als goedkeurend orgaan, verpanding van aandelen toestaan en geen erfrechtelijke blokkade kennen. $\mathrm{Bij}$ de niet intern-besloten vennootschap bestaat geen bezwaar tegen het afgeven van volmachten met betrekking tot het uitoefenen van het stemrecht door anderen dan de stemgerechtigden. Ook het verlenen van een doorlopende volmacht zal niet op weerstand stuiten. De aandeelhouder zal zich zonder bezwaar kunnen laten vertegenwoordigen bij het uitoefenen van zijn stemrecht. Kortom, bij de niet intern-besloten vennootschap staat het intuitu personae karakter veel minder op de voorgrond, terwijl, daarmee samenhangend, de aandeelhouders nauwelijks geïnteresseerd zijn in de samenstelling van de aandeelhoudersvergadering.

\section{c. De open naamloze vennootschap}

De open naamloze vennootschap is de vennootschap die alleen aandelen aan toonder danwel vrij royeerbare certificaten van aandelen aan toonder heeft uitgegeven die al dan niet ter beurze noteren. De aandelen c.q. certificaten van de vennootschap zijn verspreid over een groot aantal onbekende beleggers.

\section{d. De intern-besloten naamloze vennootschap}

Het tweede lid van art. 335 BW geeft een definitie van een (intern-) besloten naamloze vennootschap. Een naamloze vennootschap wier statuten uitsluitend aandelen op naam kennen, een blokkeringsregeling bevatten en niet toelaten dat met medewerking van de vennootschap certificaten aan toonder worden uitgegeven, wordt gelijk gesteld aan een besloten vennootschap. Voor deze variant geldt in principe hetzelfde als eerder werd opgemerkt voor de intern-besloten vennootschap. ${ }^{341}$ Tot deze categorie zou ik ook de naamloze vennootschap rekenen die - geblokkeerde - aandelen op naam plaatst bij het AK, dat vervolgens van de op

340 In deze zin C.A. Schwarz, diss. p. 73.

$34 \mathrm{l}$ De statuten van deze intern-besloten naamloze vennootschap zullen een aanbiedingsblokkade bevatten, zullen geen vrije kring kennen, zullen de mogelijkheid tot verpanding van aandelen uitgesloten dan wel sterk beperkt bebben en zullen een erfrechtelijke blokkade bouden. 
naam gestelde aandelen certificaten aan toonder uitgeeft, terwijl de certificaten niet of uiterst beperkt royeerbaar zijn, danwel slechts vrij royeerbaar in combinatie met een $1 \%$-regeling.

\section{e. De gemengde naamloze vennootschap}

Tussen de open naamloze vennootschap en de besloten naamloze vennootschap bevindt zich het terrein van de gemengde naamloze vennootschap. Dit genre vennootschap vertoont zowel kenmerken van de open als van de besloten naamloze vennootschap. Zij kent naast aandelen aan toonder (danwel certificaten aan toonder van deze aandelen) aandelen die op naam zijn gesteld. De overdracht van laatstgenoemde aandelen zal onderworpen zijn aan een statutaire blokkeringsregeling. Het bijzondere kenmerk van deze aandelen is dat er veelal speciale zeggenschapsrechten of financiële rechten aan verbonden zijn. De aandelen zullen in de voorkomende gevallen een prioriteits danwel preferent karakter hebben.

Alvorens nader ingegaan wordt op de rol die de verpanding van aandelen speelt in het spel om de beslotenheid van het samenwerkingsverband, volgt eerst een reflectie met betrekking tot hetgeen werd opgemerkt ten aanzien van de wenselijkheid van - verplichte blokkering van aandelen. Gezien het onderwerp van de volgende paragrafen zal onze aandacht voornamelijk uitgaan naar de intern-besloten vennootschap, de naamloze vennootschap met een besloten karakter en de gemengde naamloze vennootschap. Zijdelings zal evenwel aandacht worden besteed aan de 'open' naamloze vennootschap. 



\section{II.6 Een pas op de plaats; herbezinning}

Thans zal kort worden geïnventariseerd welke ruimte de wet laat om te nuanceren in de beslotenheid van het samenwerkingsverband. Men realisere zich echter dat nuanceren aantrekkelijk is, maar dat bij het behandelen van de relatie pandrecht beslotenheid de wettelijk voorgeschreven blokkeringsregeling bij de besloten vennootschap het uitgangspunt is.

\section{a. Wel of geen vrije kring}

In de eerste plaats is daar de mogelijkheid van het hebben van een statutaire vrije kring, waarbinnen de aandelen zonder beperkingen kunnen worden overgedragen. Art. 195 Lid 1 BW bepaalt:

\footnotetext{
"Een aandeelhouder kan, voor zover de statuten deze bevoegdheid niet beperken of uitsluiten, een of meer van zijn aandelen vrijelijk overdragen aan zijn echtgenoot, aan zijn bloed- en aanverwanten, in de rechte lijn onbeperkt en in de zijlijn in de tweede graad, aan een mede-aandeelhouder en aan de vennootschap. De kring van personen aan wie de aandeelhouder een of meer van zijn aandelen vrijelijk kan overdragen, kan bij de statuten worden uitgebreid tot zijn bloed- en aanverwanten in de zijlijn, of sommigen van hen, in de derde en vierde graad."
}

Binnen een intern-besloten samenwerkingsverband zal deze vrije kring, alsmede de uitbreidingsmogelijkheden, volledig uitgesloten zijn. Bij die samenwerkingsverbanden waar geen grote waarde wordt gehecht aan de interne beslotenheid zal de vrije kring niet alleen aanwezig zijn, maar ook, conform de wettelijke mogelijkheden, zijn uitgebreid.

\section{b. Goedkeuren of aanbieden}

In de tweede plaats biedt de wet een tweetal ${ }^{342}$ stelsels ter waarborging van de beslotenheid: de goedkeuringsblokkade en de aanbiedingsblokkade. In het geval van een statutaire goedkeuringsblokkade dient voor iedere overdracht, afgezien van de overdrachten die binnen de vrije kring plaatsvinden, goedkeuring te worden verleend door het daartoe bij de statuten aangewezen orgaan. Eerder in

342 Zo men wil "drietal", in de statuten kan immers een combinatie van beide stelsels worden opgenomen. Zo'n combinatie van het goedkeurings- en aanbiedingsstelsel kan een extra bescherming bieden voor het besloten karakter van de vennootschap. Op deze wijze worden namelijk twee toetsingsmomenten gecreëerd in het geheel van de overdracht van aandelen op naam. Zie ook Handboek (1992), nr 181.3. 
mijn betoog merkte ik op dat, in het geval waarin de samenwerkenden de beslotenheid van de vennootschap nastreven, dit goedkeurend orgaan steeds de algemene vergadering van aandeelhouders zal moeten zijn. Immers, kenmerk van de beslotenheid is dat de aandeelhouders bepalen wie tot hun samenwerkingsverband toetreedt. Statutair kan echter worden bepaald dat de goedkeuring voor de overdracht van aandelen dient te worden verkregen van de raad van commissarissen, het bestuur of een ander orgaan van de vennootschap dan de algemene vergadering. ${ }^{343}$ De goedkeuringsblokkade zal dus met name worden benut door die vennootschappen die ondanks het aan hun opgelegde besloten karakter, min of meer open willen zijn. Daarnaast is, bij een goedkeuringsblokkade waar de algemene vergadering van aandeelhouders als goedkeurend orgaan optreedt, de vennootschap zo besloten als de meerderheidsaandeelhouder wenst. Binnen een vennootschap met een werkelijk besloten karakter zal steeds voor een aanbiedingsblokkade worden gekozen, danwel voor een goedkeuringsblokkade waarbij de AVA steeds het goedkeurend orgaan is en het besluit tot het al dan niet verlenen van goedkeuring aan de overdracht van aandelen op naam met algemene stemmen moet worden genomen.

In geval van een statutaire aanbiedingsblokkade wordt een aandeelhouder die zijn aandelen wenst over te dragen verplicht deze eerst aan te bieden aan zijn medeaandeelhouders. Een aanbiedingsblokkade, waarbij ieder lid van het samenwerkingsverband in staat wordt gesteld te reflecteren op de aangeboden aandelen, past dan ook bij uitstek binnen het kader van de intern-besloten vennootschap. Iedere afzonderlijke aandeelhouder kan waken over het besloten karakter van de vennootschap. Het besloten karakter van het samenwerkingsverband kan nader worden geaccentueerd door te bepalen dat, wanneer aandeelhouders, tot wie zich het aanbod richt, om welke reden dan ook, dit aanbod niet - kunnen - aanvaarden, de statuten voorschrijven dat het aanbod dient te geschieden aan andere gegadigden. Deze worden aangewezen door een bij de statuten daarmee belast orgaan van de vennootschap. Mijns inziens zal dit bij voorkeur wederom de algemene vergadering moeten zijn. Ook hier acht ik het zeer wel verdedigbaar dat aan het besluit tot aanwijzing van een andere gegadigde een versterkte meerderheid wordt verbonden.

343 Ingevolge de Departementale Richtlijnen 1986 kunnen statutair als goedkeurend orgaan worden aangewezen: de algemene vergadering van aandeelhouders, de vergadering van houders van een bepaald soort, het bestuur, de raad van commissarissen en de gecombineerde vergadering van het bestuur en de raad van commissarissen. 


\section{c. Verpanding van aandelen; uitgesloten of niet}

De wettelijk voorgeschreven beslotenheid kan enigszins worden versoepeld door statutair de weg voor de verpanding van aandelen open te stellen. In de volgende paragraaf zal nader worden ingegaan op de gevolgen voor de beslotenheid van het samenwerkingsverband indien een pandrecht op aandelen op naam in een besloten vennootschap wordt gevestigd. Op deze plaats een schot voor de boeg. Conform de regeling van art. $198 \mathrm{BW}$ kan een pandrecht op aandelen op naam worden gevestigd. Statutair kan dit worden uitgesloten. Indien een pandrecht op de aandelen in de besloten vennootschap kan worden gevestigd, blijft het stemrecht dat aan die aandelen is verbonden in principe bij de aandeelhouder berusten. Men zou kunnen concluderen dat door het vestigen van een pandrecht op aandelen in een besloten samenwerkingsverband, de beslotenheid in beginsel niet op de tocht komt te staan. Immers, de financiële rechten verbonden aan het aandeel worden uitgeoefend door de pandhouder, maar de zeggenschapsrechten, die bepalend zijn voor het besloten karakter van de vennootschap, blijven bij het oorspronkelijke lid van het samenwerkingsverband. Deze conclusie is mijns inziens slechts gedeeltelijk correct. Het stemrecht blijft, zonder afwijkende statutaire danwel contractuele regeling, weliswaar bij de andeelhouder/pandgever berusten, echter, de pandhouder kan, indien de statuten hiertoe de mogelijkheid creëren, daarentegen wel de rechten die door de wet worden toegekend aan de houders van met medewerking der vennootschap uitgegeven certificaten van aandelen verkrijgen. Een van deze rechten verschaft de pandhouder toegang tot de algemene vergadering van aandeelhouders alwaar hij het recht heeft het woord te voeren. De pandhouder heeft alsdan geen stemrecht, wel kan hij trachten binnen de algemene vergadering, door middel van het uitoefenen van zijn sprekersrecht, van zijn gevoelen blijk te geven en op deze wijze het stemgedrag binnen de algemene vergadering te beïnvloeden. Hierdoor wordt de beslotenheid van het besloten samenwerkingsverband van aandeelhouders doorbroken, zij het niet in directe maar wel in indirecte zin. Bij een intern-besloten samenwerkingsverband zal de vestiging van een pandrecht dan ook steeds uitgesloten zijn. Voorts zal de mogelijkheid zijn uitgesloten dat de pandhouder de rechten van houders van bewilligde certificaten kan uitoefenen. Wanneer verpanding van aandelen bij een echt besloten samenwerkingsverband toch mogelijk is, zou ik willen aanbevelen dat de statuten van de vennootschap de blokkeringsregeling, die geldt voor de overdracht van aandelen op naam, van overeenkomstige toepassing verklaren op de vestiging van een pandrecht op die aandelen.

Het tegengestelde zal men aantreffen bij een samenwerkingsverband dat minder of geen behoefte heeft aan een intern-besloten karakter. De statuten van deze vennootschap zullen de mogelijkheid van verpanding van aandelen op naam niet uitsluiten en aan de pandhouder zullen de rechten verbonden aan bewilligde certificaten toekomen. Sterker nog, de mogelijkheid tot overgang van stemrecht 
van aandeelhouder/pandgever op pandhouder zal eveneens niet uitgesloten zijn. Het feit dat de wetgever het besloten karakter dwingendrechtelijk wenst aan te geven leidt er wel toe dat bij de overgang van het stemrecht steeds de procedure van art. 198 BW dient te worden gevolgd. Het gegeven dat het hier een dwingendrechtelijke regeling betreft lijkt met zich te brengen dat stemovereenkomsten met een onbepaalde looptijd, die ervoor moeten zorgen dat de overgang van het stemrecht de facto onbeperkt mogelijk is, nietig zijn. ${ }^{344}$

\section{d. Wel of geen enfrechtelijke blokkade}

In het kader van de nuancering van het wettelijk gedicteerde besloten karakter van de vennootschap dient bovendien gewezen te worden op de erfrechtelijke blokkade. Ingeval van overlijden van de aandeelhouder treedt zijn erfgenaam in de rechten en plichten van de aandeelhouder ten opzichte van de vennootschap. De erfgenaam verkrijgt de aandelen onder algemene titel. Men spreekt van een 'overgang' van aandelen en niet van een overdracht, zijnde een eigendomsoverdracht onder bijzondere titel. De wettelijk voorgeschreven blokkeringsbepalingen zien slechts op een overdracht van aandelen. De zittende aandeelhouders zullen dus bij overlijden van een collega geconfronteerd worden met een doorbraak van de beslotenheid van het samenwerkingsverband, althans als de erfrechtelijke verkrijging aan een persoon buiten de, mogelijk statutair uitgesloten, vrije kring te beurt valt. Door middel van het opnemen van een statutaire 'erfrechtelijke blokkade' kan voorkomen worden dat het besloten karakter van de vennootschap wordt gefrustreerd. Schwarz schrijft hierover:

"De erfrechtelijke blokkade wil het effect van deze inbreuk op de beslotenheid bestrijden. In interm-besloten vennootschappen zal veelal statutair zijn voorzien in een aanbiedings- c.q. overdrachtsverplichting voor de aandeelhouder die aandelen krachtens erfrecht heeft verkregen, dan wel, in ruimere zin, aandelen anders dan door overdracht heeft verkregen. Op laatstbedoelde manier ontstaat derhalve een aanbiedingsverplichting in die gevallen waarin de statutaire blokkade toepassing mist bij een overgang van aandeelhouderschap. Aanbieding zal binnen het intern-besloten samenwerkingsverband, aan de mede-aandeelhouders moeten plaatsvinden. ${ }^{344}$

344 Zie voor een rechtseconomische benadering van het fenomeen stemovereenkomst $H$.J. de Kluiver, Joint ventures en stemovereenkomsten. Een rechtsvergelijkend perspectief. A.Ae 44 (1995) 5, p. 104 e.v. Schrijver signaleert een tweetal nadelen ten aanzien van stemovereenkomsten, maar staat voor het overige positief tegenover de stemovereenkomst aan het einde van zijn artikel doet hij enkele voorstellen die de regeling van stemovereenkomsten zou kunnen verbeteren.

345 C.A. Schwar, diss. p. 122. 
Bij een intern-besloten samenwerkingsverband zal een erfrechtelijke overgang van aandelen steeds statutair zijn geblokkeerd. ${ }^{346}$ Dit betekent evenwel niet dat de aandelen niet op de erfgenaam overgaan. Tot op het moment van de overdracht van de aandelen krachtens de erfrechtelijke blokkade kan de erfgenaam/aandeelhouder alle rechten verbonden aan de verkregen aandelen uitoefenen. Onder verwijzing naar de Departementale Richtlijnen '76 stelt Schwarz:

(...) aan het enkel intreden van de omstandigheid dat de aandeelhouder statutair tot overdracht van aandelen verplicht is, (kan) niet het gevolg worden verbonden dat de aandeelhouder het vergader- en stemrecht niet kan uitoefenen. Het vergader- en stemrecht kan de aandeelhouder wel ontzegd worden - en het recht op dividend kan worden opgeschor - indien en voor zolang de aandeelhouder in gebreke is aan de statutaire verplichting tot aanbieding c.q. overdracht te voldoen. ${ }^{347}$

Het komt mij voor dat een constructie van gelijke aard als de erfrechtelijke blokkade bruikbaar is in geval van een verervende crediteurspositie met daaraan gekoppeld een pandhouderschap met overdracht van het stemrecht. Stel, A en B zijn beide $50 \%$-aandeelhouder in een echt besloten vennootschap. A verpandt zijn aandelen, met overgang van het stemrecht, aan C. C komt te overlijden en zijn erfgenaam $X$ volgt hem op in al zijn rechten en verplichtingen. Dus, $X$ wordt crediteur van $A$ en wordt tevens stemgerechtigd pandhouder. De beslotenheid van het samenwerkingsverband kan hierdoor onder druk komen te staan. Dat A en B, C accepteerden als stemgerechtigd pandhouder, dus als 'lid', wil niet automatisch zeggen dat $\mathrm{X}$ ook als zodanig wordt ontvangen. Ter voorkoming van deze ongeregeldheden zou men in de statuten van een echt besloten samenwerkingsverband kunnen bepalen dat wanneer een pandrecht op aandelen op naam in de besloten vennootschap, krachtens overgang of overdracht, door een derde wordt verkregen, deze verplicht is het recht van pand, inclusief het stemrecht, aan te bieden aan de overige aandeelhouders conform de regeling van de aanbiedingsblokkade van het vierde lid van art. $195 \mathrm{BW}$. Hier ontstaat een probleem. Het gaat hier immers om een accessoir recht dat niet als zodanig en onder deze omstandigheden kan worden overgedragen. Een oplossing zou kunnen liggen in de bepaling, onderdeel uitmakend van de pandakte, dat het stemrecht, na het overlijden van de stemgerechtigde pandhouder, toekomt aan de pandgever. De andere oplossing voor het probleem, als hierboven aangegeven, lijkt ook werkbaar en niet in strijd met het bepaalde in art. $192 \mathrm{BW}$. Immers, in zodanige oplossing zou het de andere aandeelhouders vrijstaan te reflecteren op wat in feite een schuldvordering is. Dit zou betekenen dat A verplicht wordt zijn schuld aan

346 In zijn algemeenheid zal dit gelden voor iedere verkrijging onder algemene titel, dus anders dan door overdracht.

347 C.A. Schwarz, diss. p. 122-123. Schrijver verwijst naar $\S 22$ en $\S 25$ van de Departementale Richtlijnen 1976, deze Richtlijnen zijn in 1986 gewijzigd, maar hebben geen wijzigingen aangebracht in de tekst en strekking van de genoemde paragrafen. 
$\mathrm{X}$ af te lossen of, in het geval A hiertoe niet in staat is, dat de andere aandeelhouder, B, de aflossing van de schuld voor zijn rekening dient te nemen. Vindt er geen aflossing plaats dan zullen A en B moeten aanvaarden dat de beslotenheid van hun samenwerkingsverband door de stemgerechtigde pandhouder $\mathrm{X}$ wordt doorbroken.

Bij de niet intern-besloten vennootschap zal, op grond van de argumenten die reeds eerder werden aangedragen, geen behoefte bestaan aan een statutaire erfrechtelijke blokkering.

\section{e. Wel of geen vertegenwoordiging krachtens volmacht bij het uitbrengen van stemmen; stemovereenkomsten}

Zoals eerder opgemerkt zal de mogelijkheid van stemovereenkomsten en vertegenwoordiging bij het uitbrengen van stemmen bij de intern-besloten vennootschap sterk beperkt, danwel uitgesloten zijn. ${ }^{348}$ Het gaat niet aan dat aandeelhouders derden - op welke wijze dan ook - enige invloed kunnen verschaffen op het besluitvormingsproces binnen een echt besloten vennootschap. De aandeelhouder zal zijn stem persoonlijk of, in hoogst uitzonderlijke gevallen - men denke aan ziekte of langdurige afwezigheid - door middel van een vertegenwoordiger dienen uit te brengen.

Wanneer een pandhouder in een organisatorische betrekking tot de vennootschap staat, dus stemrecht kan uitoefenen, zal deze zich ook niet mogen laten vertegenwoordigen bij het uitbrengen van de stem verbonden aan het verpande aandeel. Ook zal hij zich niet mogen binden aan stemovereenkomsten met derden.

Bij de 'open' besloten vennootschap zal het probleem van doorbraak van beslotenheid, als gevolg van vertegenwoordiging bij volmacht of stemovereenkomsten met aandeelhouders of derden, niet spelen, daar de oprichters/aandeelhouders kennelijk geen waarde hechten aan het besloten karakter van het samenwerkingsverband.

Aan het voorgaande kan mijns inziens de volgende conclusie worden verbonden. Het positieve recht verplicht besloten vennootschappen met beperkte aansprakelijkheid een blokkeringsregeling in haar statuten op te nemen, waardoor de overdracht van aandelen in het kapitaal van het besloten samenwerkingsverband beperkt wordt. Voorbijgaand nu aan de vraag of voor deze wettelijke verplichting enige legitieme grond kan worden gegeven, kan worden gesteld dat de wetgever bewust of onbewust - binnen de regeling van de verplichte blokkering van

348 Zie voor een andersluidende opvatting ten aanzien van de stemovereenkomst bij een besloten vennootschap H.J. de Kluiver, Joint ventures en stemovereenkomsten. Een rechtsvergelijkend perspectief. A.Ae 44 (1995) 5, p. 105-106. 
aandelen enkele mogelijkheden biedt om het stringente overdrachtsbeleid ten aanzien van deze aandelen enigszins te versoepelen. 



\section{II.7 Verpanding van aandelen; de beslotenheid in gevaar?}

\section{II.7.1 Inleiding}

De beslotenheid van het samenwerkingsverband kan op een aantal wijzen in het gedrang komen. Als de pandhouder het stemrecht verbonden aan de verpande aandelen gaat uitoefenen dringt hij binnen in het besloten samenwerkingsverband. De overgang van het stemrecht is echter geen noodzakelijke voorwaarde voor doorbraak van de beslotenheid. De pandhouder die geen stemrecht heeft kan, indien de statuten dit bepalen en bij de akte van vestiging van het pandrecht niet anders is bepaald, de rechten uitoefenen die worden toegekend aan de houders van met medewerking der vennootschap uitgegeven certificaten van aandelen. In de situatie waarin de pandhouder geen stemrecht kan uitoefenen, maar wel de certificaathoudersrechten heeft, is hij gerechtigd ter vergadering te verschijnen en aldaar het woord te voeren. Op deze wijze kan hij invloed trachten uit te oefenen op die handelingen en besluiten die het besloten karakter van de vennootschap kunnen aantasten. ${ }^{349}$

Men stelle zich voorts het geval voor dat de pandhouder gerechtigd is tot het uitbrengen van de aan de verpande aandelen verbonden stemmen. De overdracht van de aandelen is geblokkeerd door middel van een goedkeuringsregeling. Op enig moment wenst een van de zittende aandeelhouders zijn aandelen over te dragen. Deze overdracht is onderworpen aan de goedkeuringsblokkade. Goedkeuring dient, in het geval van een intern-besloten samenwerkingsverband, verleend te worden door de algemene vergadering van aandeelhouders. De leden van dit orgaan worden geconfronteerd met de aandeelhouder/pandgever die ter vergadering verschijnt en daar ook het woord mag voeren, alsmede met de stemgerechtigde pandhouder. Deze laatste kan door middel van het uitbrengen van zijn stem meebepalen of de goedkeuring al dan niet zal worden verleend, danwel een andere gegadigde zal worden aangewezen aan wie de aandelen worden overgedragen. Zeker indien de pandhouder een pakket van $51 \%$ in pand heeft verkregen zal hij de dienst binnen het samenwerkingsverband kunnen uitmaken. De beslo-

349 Ook kan de pandhouder - onder omstandigheden - zeggenschap verkrijgen in de vennootschap na executie van het pand. 
tenheid van het met aanzien des persoons aangegane samenwerkingsverband is daarmee in ieder geval doorbroken. ${ }^{350}$

Het zal duidelijk zijn dat in geval de statuten van de vennootschap een aanbiedingsblokkade kennen dit gevaar minder aanwezig is. Het aanbod van de overdragende aandeelhouder richt zich immers tot de aandeelhouder/pandgever en niet tot de pandhouder.

De vraag naar de mogelijke doorbraak van de beslotenheid zal hierna worden behandeld in een aantal vennootschapsrechtelijke situaties waarbij een pandrecht, onder verschillende condities, op een meerderheidspakket wordt gevestigd. Dit alles zal geschieden tegen de achtergrond van een inhoudelijke analyse van de artt. 89 en $198 \mathrm{BW}$. In de eerste situatie wordt een pandrecht gevestigd op de toonderaandelen in een grote 'open' naamloze vennootschap. Het tweede geval behandelt de verpanding van een pakket aandelen op naam in een besloten vennootschap met beperkte aansprakelijkheid. In het derde geval zal aandacht worden besteed aan de situatie waarin een pandrecht wordt gevestigd op, enerzijds aandelen op naam en anderzijds aandelen aan toonder, in een gemengde vennootschap. Hierbij kan gedacht worden aan een grote ter beurze genoteerde, vennootschap, die preferente beschermingsaandelen heeft geplaatst bij een stichting, aan een naamloze vennootschap die een aantal machtsaandelen (prioriteitsaandelen) heeft uitgegeven aan bepaalde personen of aan een, al dan niet ter beurze genoteerde, naamloze vennootschap die naast aandelen aan toonder een aanzienlijk pakket geblokkeerde aandelen op naam heeft geplaatst.

Vervolgens zal aandacht worden besteed aan het mogelijke probleem van de doorbraak van het besloten karakter van de verschillende typen vennootschappen ten gevolge van het vestigen van een stil pandrecht op aandelen in het kapitaal van deze vennootschappen.

Aan het einde van dit hoofdstuk zal worden ingegaan op de middelen die de wetgever heeft gecreëerd die zien op het in stand houden en beschermen van de beslotenheid van de vennootschap.

350 In dit verband zou de vrasg kunnen opkomen of art. 12 BW hier een onneembare barrage zou kunnen vormen. Immers, verdedigbaar lijkt het standpunt dat, wanneer de algemene vergadering van aandeelhouders dient te besluiten over toekenning van het stemrecht op verpande aandelen aan de pandhouder, de aandeelhouder in het licht van dit artikel het stemrecht dient te worden ontzegd. Ik zou menen dat de zakelijk gerechtigde op het aandeel, onder de omstandigheden als hier aan de orde zijnd, dient te worden beschouwd als 'aandeelbouder' in de zin van dit artikel. Indien men een andere mening op dit punt zou hebben, zou de materielle beslotenheid van de vennootschap, ten aanzien van de pandhouder, verder gaan dan ten aanzien van de aandeelhouder. Immers, indien er sprake is van een statutaire goedkeuringsblokkade, en het niet zou gaan over toekenning van het stemrecht aan de pandhouder, maar om overdracht van aandelen aan een derde, zou de aandeelhouder mijns inziens steeds ten volle van zijn zeggensmacht in de algemene vergadering van aandeelhouders gebruik kunnen maken. 
II.7.2 Artikel $89 \mathrm{BW}$; open naamloze vennootschap; geen schending van de beslotenheid

De relatie open naamloze vennootschap ${ }^{351}$ en beslotenheid kan relatief kort worden afgehandeld.

De beslotenheid van het samenwerkingsverband zal in het algemeen geen rol spelen bij de open naamloze vennootschap. Het samenwerkingsverband dat in de vorm van zo'n naamloze vennootschap wordt aangegaan, zal veelal de intentie hebben door middel van een beroep op het beleggend publiek deel te nemen aan het maatschappelijk verkeer. De leden van dit verband zullen er dan ook, in beginsel, geen belang bij hebben dat toetreding tot en/of uittreding uit hun vennootschap op welke wijze dan ook wordt belemmerd.

De bevoegdheid tot verpanding van aandelen aan toonder kan dan ook nimmer bij statuten worden uitgesloten of beperkt. ${ }^{352} \mathrm{Er}$ is in dit geval geen vennootschappelijk belang dat zich tegen verpanding van toonderaandelen verzet.

Ten aanzien van het stemrecht geldt de hoofdregel dat dit toekomt aan de aandeelhouder. Van deze hoofdregel kan worden afgeweken. In de akte waarbij het pandrecht wordt gevestigd kan daartoe worden bepaald dat het stemrecht aan de pandhouder toekomt indien deze een persoon is aan wie de aandelen vrijelijk mogen worden overgedragen. In het algemeen kan men stellen dat toonderaandelen steeds vrijelijk van hand tot hand kunnen gaan.

In afwijking van het vorenstaande kan, als de statuten der vennootschap hiertoe de mogelijkheid bieden in de pandakte worden bepaald, dat het stemrecht bij de aandeelhouder/pandgever blijft berusten tot het moment waarop deze, na eerst in gebreke te zijn gesteld, zijn lossingsverplichtingen niet nakomt. ${ }^{333}$ Deze latere overgang van het stemrecht wordt mogelijk gemaakt door de laatste volzin van het derde lid van art. 89 BW. ${ }^{354}$

Een andere consequentie van deze volzin is dat de overgang van het stemrecht van aandeelhouder/pandgever naar pandhouder statutair kan worden uitgesloten. Aardig is in dit verband te wijzen op een passage uit het Handboek. In tegenstelling tot de opvatting verkondigt in de elfde druk van het Handboek,

"De statuten kunnen bepalen, dat het stemrecht niet aan de pandhouder kan toekomen. "3ss

$35 I$ In $\S$ II.5 werd de open naamloze vennootschap omschreven als een vennootschap die alleen aandelen aan toonder dan wel certificaten van aandelen aan toonder heeft uitgegeven die al dan niet ter beurze noteren. De aandelen c.q. certificaten van aandelen in deze vennootschap zijn verspreid over een groot aantal onbekende beleggers.

352 Zie over deze materie § I.3.3.

353 Zie in dit verband HR 6 april 1990, NJ 1991, 559 (Canadian Land).

354 Deze latere overgang dient wel te worden geregistreerd in het aandeelhoudersregister, daar anders legitimatieproblemen kunnen ontstaan wanneer de stemgerechtigde pandhouder ter vergadering verschijnt.

355 Handboek (1989), nr. 184. 
lezen wij in de twaalfde druk,

"De statuten van een n.v. kunnen de eigenaar van een toonderaandeel niet het recht ontzeggen om aan de pandhouder het stemrecht op de aandelen te verlenen. ${ }^{\text {n36 }}$

Deze opvatting lijkt mij regelrecht in strijd met de wet. Kan het zijn dat Van der Grinten zich heeft laten verwarren door de wettelijke regeling van het vruchtgebruik op aandelen. Immers, bij het vestigen van een vruchtgebruik op aandelen kunnen de statuten van een vennootschap niet bepalen dat het stemrecht te allen tijde aan de vruchtgebruiker kan worden onthouden. Slechts in het geval waarin de vruchtgebruiker een persoon is aan wie de aandelen niet vrijelijk kunnen worden overgedragen, kan het goedkeurend orgaan haar goedkeuring weigeren zodat het stemrecht niet overgaat. ${ }^{357}$

Reeds eerder merkte ik op dat ik dit een merkwaardige situatie vind. De aandeelhouder zou zijn aandelen wel aan een potentiële pandhouder kunnen verkopen, maar enkel het overdragen van het stemrecht zou aan de pandhouder verboden kunnen worden. Ik zou willen verdedigen dat voor een dergelijke statutaire bepaling, onder omstandigheden, geen ratio aanwijsbaar is. Het zal immers veelal het geval zijn dat een pandhouder slechts dan tot kredietverlening aan de aandeelhouder/pandgever zal overgaan indien hij het stemrecht verbonden aan deze aandelen kan uitoefenen. Immers, door uitoefening van het stemrecht kan hij trachten de waarde van het pand te bewaken. ${ }^{358}$ Verbieden de statuten de overgang van het stemrecht, dan bestaat de kans dat de aandeelhouder van een zekere kredietfaciliteit verstoken blijft.

\section{II.7.3 Artikel 198; de intern-besloten vennootschap; gevaar voor doorbraak}

In paragraaf I.6. werd kort aandacht besteed aan de overgang van het stemrecht verbonden aan verpande aandelen in een besloten vennootschap. Op het eerste gezicht bestaat er uniformiteit tussen de regeling van de naamloze en besloten vennootschap op dit punt. Toch is er een groot verschil dat direct verklaarbaar is tegen de achtergrond van het door de wetgever gedicteerde karakter van de besloten vennootschap.

De hoofdregel is dat ook bij de besloten vennootschap het stemrecht op de verpande aandelen in beginsel bij de aandeelhouder/pandgever blijft. Van deze hoofdregel kan worden afgeweken. Het stemrecht kan op de pandhouder overgaan indien dit bij de vestiging van het pandrecht is bepaald en de pandhouder

356 Handboek (1992), nr. 184.

357 Zie art. 88 lid 3 BW.

358 Dit zal zeker het geval zijn als de pandhouder een aanzienlijk pakket aandelen in pand onder zich heeft. 
een persoon is aan wie de aandelen vrijelijk kunnen worden overgedragen. De pandhouder behoort in dit geval dan tot de vrije kring beschreven in art. 195 lid $1 \mathrm{BW}$. In de praktijk is deze vrije kring bij de intern-besloten samenwerkingsverbanden veelal uitgesloten omwille van het besloten karakter van de vennootschap. Behoort de pandhouder niet tot de vrije kring dan kan hij het stemrecht slechts verkrijgen indien de overgang in de pandakte wordt vastgelegd en de vestiging van het pandrecht is goedgekeurd door het orgaan dat statutair is aangewezen goedkeuring te verlenen aan een voorgenomen aandelenoverdracht. Dit orgaan zal idealiter de algemene vergadering van aandeelhouders zijn. Immers, dat is, bij de werkelijk besloten vennootschap, bij uitstek het orgaan dat dient te beslissen wie deel kan uitmaken van het samenwerkingsverband. Zou dit een ander vennootschapsorgaan zijn, bijvoorbeeld het bestuur of de raad van commissarissen, dan zou de beslissing omtrent het al dan niet instandhouden van het besloten karakter van het samenwerkingsverband onttrokken worden aan de personen die, in eerste instantie, omwille van die beslotenheid en met het oog op een ieders persoonlijke kwaliteiten, met elkaar in zee zijn gegaan. ${ }^{359}$

De laatste volzin van art. 198 lid $3 \mathrm{BW}$ vormt het sluitstuk van de regeling inzake de overgang van het stemrecht.

"De bevoegdheid tot toekenning van het stemrecht aan de pandhouder kan in de statuten worden uitgesloten."

In deze bepaling ligt het verschil met de regeling van de naamloze vennootschap. De statuten van de besloten vennootschap kunnen, indien de mogelijkheid van verpanding van aandelen niet is uitgesloten, limitatief de volgende mogelijkheden inhouden: a. het stemrecht op de verpande aandelen verblijft te allen tijde bij de aandeelhouder/pandgever of b. niet de aandeelhouder/pandgever heeft het stemrecht, maar de pandhouder indien zulks bij de vestigingsakte is bepaald en de pandhouder een persoon is die behoort tot de personen genoemd in art. 195 lid 1 BW, danwel een persoon is die niet tot die kring behoort maar aan de overgang

359 Eerder in dit hoofdstuk beschreef ik dat de intem-besloten vennootschap bij voorkeur een aanbiedingsblokkade boven een goedkeuringsblokkade in haar statuten zal opnemen dit ter meerdere waarborging van het besloten karakter van de vennootschap. De goedkeuringsregeling zoals vervat in art. 198 lid 3 BW ten aanzien van de overgang van het stemrecht van aandeelhouder naar pandhouder verhoudt zich slecht met de regeling ter beveiliging van het besloten karakter. De doorbraak van de beslotenheid staat hier immers weer ter discretie van de meerderheid van de - algemene vergadering van aandeelhouders. Een pandgever/aandeelhouder die zijn meerderheidspakket verpandt zal, mogelijkerwijs voorbijgaand aan de belangen van de minderheidsaandeelhouders, het besloten karakter van de vennootschap illusoir kunnen maken. De oplossing voor dit probleem ligt mijns inziens in het verbieden van de overgang van het stemrecht. 
van het stemrecht goedkeuring is verleend door de algemene vergadering van aandeelhouders.

Een regeling in strijd met de hierboven genoemde zal rechtens niet geldig zijn. De wet biedt immers geen gelegenheid, in afwijking van de regeling van de naamloze vennootschap, om een bepaling in de statuten op te nemen die verschilt van het bepaalde in art. 198 lid $3 \mathrm{BW}$. Een contractuele bepaling houdende een overgang van het stemrecht op het moment waarop de aandeelhouder/pandgever zijn verplichtingen niet nakomt, is in strijd zijn met de wet; het is immers een regeling die niet gedekt wordt door de tekst van art. $198 \mathrm{BW}$.

Dat de BV-regeling ten aanzien van de overgang van het stemrecht op verpande aandelen meer rigide is dan die van de naamloze vennootschap is goed verklaarbaar. Uitgaande van het wettelijk verplichte besloten karakter van de vennootschap zal alles in het werk moeten worden gesteld om de beslotenheid van het samenwerkingsverband te beschermen. Indien de wetgever aan het einde van het derde lid van art. $198 \mathrm{BW}$ een open bepaling, gelijk die van de naamloze vennootschap, zou hebben opgenomen, dan zou dit, bij de intern-besloten vennootschap, kunnen leiden tot een doorbraak van het besloten karakter van de vennootschap.

Is er sprake van een intern-besloten samenwerkingsverband, dan zal mijns inziens statutair worden bepaald dat het stemrecht op de verpande aandelen berust bij de aandeelhouder en dat de pandhouder nimmer aanspraak kan maken op het stemrecht verbonden aan de verpande aandelen. Men zou nu kunnen opmerken dat hier een gelijke situatie ontstaat als bij de naamloze vennootschap. Een persoon aan wie een aandeelhouder wel zijn aandelen zou kunnen overdra$\operatorname{gen}^{360}$, zou als pandhouder nimmer stemrecht kunnen verkrijgen op de aan hem in pand gegeven aandelen. Voor de naamloze vennootschap verdedigde ik dat voor deze situatie, onder omstandigheden, geen ratio aanwijsbaar is. Hier zou ik evenwel anders willen concluderen. Het belang van de vennootschap, het handhaven van het besloten karakter, indien gewenst, prevaleert boven enig economische belang van de aandeelhouder. ${ }^{361}$

360 Deze situatie doet zich voor wanneer de statuten van de intern-besloten vennootschap een aanbiedingsregeling kennen terwijl de zittende aandeelhouders niet op het aanbod hebben gereflecteerd, dan wel er statutair een goedkeuringsblokkade is opgenomen en het goedkeurend orgaan toestemming heeft gegeven aan de voorgenomen overdracht. De vrije kring, binnen welke aandelen zonder inachtneming van de blokkeringsregeling kunnen worden overgedragen, zal bij een interm-besloten samenwerkingsverband veelal uitgesloten zijn.

361 Ter nuancering de volgende opmerking. Er zijn omstandigheden denkbaar waarin het belang van de vennootschap en het belang van de aandeelhouder identiek zijn. Men denke aan de het geval van de directeur-groot (enig) aandeelhouder van een besloten vennootschap die in zijn eigen belang een lening aangaat onder verpanding van al zijn aandelen. Het feit dat hierbij het stemrecht verbonden aan die aandelen overgaat op een derde partij betekent sec het einde van de beslotenheid. Echter, het vennootschappelijk belang wordt in beginsel niet geschaad. 
Kan men bewerkstelligen dat in geen enkel geval de beslotenheid van de vennootschap in gevaar komt indien een der deelnemers aan het samenwerkingsverband zijn aandelen aan een derde in pand geeft? Mijns inziens is dit mogelijk. Statutair zal dan echter een regeling zoals in de vorige alinea geschetst moeten worden opgenomen. ${ }^{362}$

Neemt men in de statuten een regeling op gelijk die van de eerste en tweede volzin van het derde lid van art. $198 \mathrm{BW}$, dan loopt men de kans dat de beslotenheid van de vennootschap barsten gaat vertonen of geheel doorbroken wordt. Zelfs door het uitsluiten van een vrije kring kan men dit niet voorkomen. Men stelle zich het volgende geval voor: $A$ is een van de aandeelhouders in een internbesloten vennootschap. Voor de overdracht van de aandelen in deze vennootschap geldt een statutaire aanbiedingsblokkade. A wenst zijn pakket aandelen, groot $51 \%$, te verpanden aan een niet met de vennootschap verbonden derde. Tevens is hij voornemens het stemrecht, verbonden aan de te verpanden aandelen, te laten toekomen aan de pandhouder. Het pandrecht wordt gevestigd onder de ontbindende voorwaarde dat de algemene vergadering van aandeelhouders haar goedkeuring niet verleent aan de vestiging van het pandrecht (waarbij het stemrecht overgaat). In een bijeengeroepen vergadering legt A zijn plannen voor aan zijn mede-aandeelhouders. Deze zijn niet erg blij met A's voomemen. Het komt op een stemming aan waarbij, door het stemgedrag van A, de aandeelhoudersvergadering aan het vestigen van het pandrecht met overgang van het stemrecht goedkeuring verleent. Hiermede heeft de algemene vergadering gesproken en worden de mede-aandeelhouders van A geconfronteerd met een 'vreemde eend in de bijt'.

Wij zien ons hier geplaatst voor een curiositeit in het wettelijk systeem betreffende de overdracht en verpanding van aandelen op naam. Inventariseren wij de feiten: een intern-besloten samenwerkingsverband beperkt de overdracht van aandelen in haar kapitaal door middel van een aanbiedingsregeling. Verpanding van aandelen is niet verboden. Statutair is ook de bevoegdheid tot toekenning van het stemrecht aan een pandhouder niet uitgesloten.

Laten wij er nu even van uitgaan dat A zijn aandelen niet wenst te verpanden maar wil overdragen aan een derde. Ten gevolge van de statutaire aanbiedingsregeling dient A zijn pakket eerst aan te bieden aan de overige aandeelhouders. Op

362 Opmerking verdient het feit dat de pandhouder die geen stemrecht heeft, onder omstandigheden, de rechten verkrijgt die de wet toekent aan de houders van bewilligde certificaten. De pandhouder verkrijgt alsdan het recht ter vergadering te verschijnen en aldaar het woord te voeren. Op deze wijze kan hij enige invloed doen gelden binnen het intern-besloten samenwerkingsverband. In voorkomende gevallen zullen deze rechten aan de pandhouder onthouden worden, gezien het karakter van het samenwerkingsverband. De laatste volzin van het vierde lid van art. 2:198 BW opent hiertoe de mogelijkheid. 
dit punt aanbeland zijn er twee scenario's denkbaar. In het eerste - en gunstigste geval reflecteren de aandeelhouders en aanvaarden het aanbod. Dit heeft tot gevolg dat het intern-besloten samenwerkingsverband daadwerkelijk haar karakter behoudt. Het tweede geval is gecompliceerder van aard. Het aanbod wordt niet aanvaard door de zittende aandeelhouders, er vindt dus geen reflectie plaats. Alsdan zal A zijn aanbod moeten richten tot andere gegadigden die door een statutair daarmee belast orgaan - de algemene vergadering - worden aangewezen. Ook hier zijn twee opties denkbaar. De aangewezen gegadigde koopt à contant de aangeboden aandelen. Er van uitgaande dat de aangewezen derde de voorkeur geniet van de - meerderheid van de - algemene vergadering, kan men stellen dat het intern-besloten karakter van de vennootschap in principe behouden blijft. De tweede optie kan leiden tot doorbraak van het besloten karakter. Indien mocht blijken dat de aangewezen gegadigde er niet in slaagt het gehele pakket tegen contante betaling over te nemen is de aanbieder, binnen een periode van drie maanden na deze vaststelling, vrij de aandelen aan een ander overdragen. De invloed die de individuele aandeelhouders kunnen doen gelden in geval van een aanbiedingsblokkade is aanzienlijk.

Terug naar de casus. A wenst zijn pakket te verpanden met overgang van het stemrecht aan een derde en bewandelt de voorgeschreven weg. De wet bepaalt in art. 198 lid $3 \mathrm{BW}$ dat, indien de pandhouder niet een persoon is die behoort tot de vrije kring van art. 195 lid $1 \mathrm{BW}$, hem het stemrecht verbonden aan de verpande aandelen slechts kan toekomen als dit bij de vestiging van het pandrecht is bepaald en de vestiging van het pandrecht is goedgekeurd door het vennootschapsorgaan dat statutair is aangewezen om goedkeuring te verlenen tot een voorgenomen overdracht van aandelen. Is zo'n orgaan niet aangewezen, dan dient de gocdkeuring te worden verkregen van de algemene vergadering. ${ }^{363}$

Deze wettelijke regeling lijkt niet te stroken met het door de wetgever gedicteerde besloten karakter van de vennootschap. Enerzijds wordt het intern-besloten samenwerkingsverband tegen indringers beschermd door de werking en de strekking van de aanbiedingsregeling in de statuten van de vennootschap. Anderzijds wordt een mogelijke doorbraak van het besloten karakter van de vennootschap, ten gevolge van de overgang van het stemrecht op de pandhouder, overgelaten aan de goedkeuring van (de meerderheid van) de algemene vergadering.

363 Zo'n goedkeuring verlenend orgaan zal in geval van een statutaire aanbiedingsblokkade veelal niet zijn aangewezen, tenzij er sprake is van een beperking van de overdracht van aandelen door middel van een combinatie van een aanbiedingsblokkade en een goedkeuringsregeling. Is er geen goedkeurend orgaan aangewezen zal de algemene vergadering van aandeelhouders moeten beslissen over het al dan niet toestaan van de vestiging van het pandrecht met overgang van het stemrecht op de pandhouder. 
Deze conclusie zou afgezwakt kunnen worden door de opmerking dat het opnemen van een aanbiedingsblokkade niet te allen tijde hoeft te betekenen dat een der zittende aandeelhouders op het aanbod kan en zal reflecteren en zo de beslotenheid van het samenwerkingsverband weet te waarborgen. Vindt er geen reflectie plaats, dan zal het daartoe aangewezen orgaan een andere gegadigde kunnen aanwijzen die de aandelen koopt. Dit orgaan zal de algemene vergadering van aandeelhouders zijn. De vraag is nu aan de orde of we hier inderdaad te maken hebben met een curiositeit in de wettelijke regeling die zich geenszins verhoudt met het wettelijk voorgeschreven, en door de vennootschap ook gewenste, besloten karakter van de vennootschap. De aanbiedingsblokkade, die in beginsel een sterke waarborg biedt ter bescherming van het besloten karakter van de intern-besloten vennootschap, wordt als het ware ter zijde gesteld door een goedkeuringsregeling. Deze goedkeuring wordt, in tegenstelling tot de gang van zaken bij een aanbiedingsregeling waarbij alle individuele aandeelhouders kunnen beslissen over het al dan niet teloor gaan van de beslotenheid, volledig aan discretie van de meerderheidsaandeelhouder over gelaten. De minderheidsaandeelhouders zijn niet bij machte de vestiging van het pandrecht met overgang van stemrecht te verhinderen. Echter, is dit niet gelijk aan de situatie waarin de vennootschap zich bevindt indien geen der aandeelhouders kan reflecteren op het aanbod van een meerderheidsaandeelhouder. De algemene vergadering zal ook dan een andere gegadigde dienen aan te wijzen aan wie de overdragende aandeelhouder zijn aandelen kan verkopen. Deze gegadigde zal ook door de meerderheid van de algemene vergadering worden aangewezen.

Deze redenering behelst een kern van waarheid. Echter, deze kern is niet zo hard dat daarmee de eerder ingenomen stelling, dat de wettelijke regeling van art. 198 lid 3 BW niet strookt met het idee van de verplichte beperking van de overdracht van aandelen op naam in een besloten vennootschap, ontkracht kan worden. In geval van een aanbiedingsblokkade is, zoals reeds werd opgemerkt, de invloed van de individuele aandeelhouders bijzonder groot. Zij zijn - op diverse momenten in het proces - in staat te waken over het besloten karakter van de vennootschap. De bepaling van art. 198 lid 3 BW biedt duidelijk minder mogelijkheden ter bescherming van het karakter van de interm-besloten vennootschap. Namelijk niet iedere individuele aandeelhouder beslist over het toekennen van stemrecht aan de pandhouder, maar de meerderheid.

Concluderend kan gesteld worden dat, wanneer men de beslotenheid van de vennootschap te allen tijde wenst te garanderen, de mogelijkheid van verpanding van aandelen statutair uitgesloten dient te worden. Wordt de mogelijkheid van verpanding van aandelen geboden, dan dient men te bepalen dat aan de pandhouder nimmer het stemrecht kan toekomen. Hiermede wordt de beslotenheid van het samenwerkingsverband slechts in eerste instantie gewaarborgd. Immers, komt de pandgever zijn verplichtingen jegens de pandhouder niet na dan kan de pandhouder overgaan tot executie van het pand. Dit kan het einde der beslotenheid met 
zich brengen. ${ }^{364}$ Ware het niet beter geweest in het kader van de, voor de wetgever zo belangrijke, beslotenheid in de wet vast te leggen dat aandelen op naam in een besloten vennootschap niet kunnen worden verpand? Mijns inziens creëert de wetgever een zekere contradictie door enerzijds vast te houden aan een strikte blokkeringsregeling en anderzijds, wellicht ongewild of ondoordacht, een reële mogelijkheid tot doorbraak van de beslotenheid te aanvaarden.

Aan het einde van deze paragraaf is een relativerende opmerking op zijn plaats. Men kan zich afvragen of aan het gevaar van doorbraak van de beslotenheid van het vennootschappelijk verband wel zo zwaar moet worden getild. Bouwen wij voort op de gedachte, geopperd in paragraaf II.4, waarin werd gepleit voor de afschaffing van de wettelijk voorgeschreven beperking van de overdracht van aandelen op naam in een besloten vennootschap, dan zou gesteld kunnen worden dat het feit, dat ten gevolge van verpanding van aandelen de beslotenheid doorbroken wordt, ook niet aan de eigen verantwoordelijkheid van de vormgevers van de statuten dient te worden overgelaten. De besloten vennootschap is - in beginsel - een intuitu personae aangegaan, dus besloten samenwerkingsverband. Op een aantal plekken doorbreekt de regeling van het pandrecht op aandelen die beslotenheid. De wettelijke regeling maakt het de leden van een echt besloten samenwerkingsverband evenwel mogelijk om iedere inbreuk op het besloten karakter tegen te gaan, terwijl de mogelijkheid van een inbreuk kan worden genuanceerd al naar gelang de mate van verlangde beslotenheid. Vormt deze constatering geen bijkomend argument voor het facultatief maken van de nu nog wettelijk voorgeschreven blokkering van aandelen in een besloten vennootschap?

\section{II.7.4 Besloten en gemengde naamloze vennootschap; het gevoelige raakvlak}

Met de invoering van de geschillenregeling ${ }^{365}$ in de Nederlandse wetgeving werd tevens een wettelijke omschrijving gegeven van een besloten naamloze vennootschap. Deze besloten naamloze vennootschap is qua organisatie en doelstelling gelijk aan de (intern-) besloten vennootschap. ${ }^{366}$ Betreffende de verpanding van aandelen op naam in een besloten naamloos samenwerkingsverband verwijs ik naar hetgeen werd opgemerkt in § II.7.3.

364 Men kan hier de relatie leggen tussen de wenelijk gedicteerde beslotenbeid enerzijds en de liberale invullingsmogelijkheid van die beslotenheid anderzijds. De blokkering van aandelen is verplicht, maar de wijze van blokkering wordt overgelaten aan de wensen van de leden van het samenwerkingsverband, zij het binnen smalle marges.

365 Ingevoerd bij Wet van 10 november 1988, Stb. 1988, 516.

$366 \mathrm{Nu}$ ten aanzien van de naamloze vennootschap geen wettelijk verplichte beperking van de overdracht van aandelen op naam geldt, zullen de vormgevers van de statuten van zo'n vennootschap, die de organisatie van de vennootschap conform de eisen van art. 335 lid 2 inrichten, steeds de intentie hebben het samenwerkingsverband intem besloten te doen zijn. 
De in de vorige twee paragrafen beschreven regelingen smelten samen in het geval waarin men wordt geconfronteerd met een gemengde naamloze vennootschap, een open naamloze vennootschap met een besloten kern.

Met name de grote, ter beurze genoteerde, naamloze vennootschap zal naast aandelen aan toonder, een aanzienlijk pakket aandelen van een bijzondere soort hebben geplaatst, danwel certificaten aan toonder van aandelen op naam hebben uitgegeven. Hetgeen werd opgemerkt ten aanzien van verpanding van aandelen bij 'open' naamloze vennootschappen geldt ook hier voor wat de uitgegeven aandelen aan toonder betreft. Ten aanzien van de aandelen op naam geldt, in beginsel, dezelfde regeling als omschreven bij verpanding van aandelen in een besloten samenwerkingsverband. ${ }^{367}$ Toch is dit raakvlak van regelingen hiermee niet afgedaan. Het bijzondere karakter van de uitgegeven aandelen in relatie tot verpanding dient nader te worden belicht. Aandelen op naam, uitgegeven door een grote naamloze vennootschap, dienen een bepaald doel. Het zijn veelal geen 'gewone' aandelen op naam. Aan deze aandelen zijn bepaalde - extra - zeggenschaps en/of financiële rechten verbonden. Een andere mogelijkheid is dat, in plaats van het toekennen van extra rechten aan het aandeel, bepaalde rechten voortvloeiend uit het aandeel worden gescheiden. Deze aspecten verdienen nadere overweging.

In de eerste plaatst wordt stil gestaan bij het karakter van het uitgegeven aandeel op naam en in de tweede plaats volgt een opmerking verband houdend met de laatste volzin van het derde lid van art. $89 \mathrm{BW}$.

Veruit de meeste van de ter beurze noterende fondsen hebben een statutaire beschermingswal opgeworpen ter voorkoming, danwel vertraging, van onvrijwillige overnames. ${ }^{368}$ Voor zo'n beschermingswal zijn tal van constructies bedacht en in praktijk gebracht. In het licht van het onderhavige thema zijn die constructies van belang waarbij, ter bescherming, aandelen op naam zijn of worden uitgegeven. Men kan hierbij denken aan de uitgifte van preferente beschermingsaandelen, prioriteitsaandelen en het plaatsten van aandelen op naam bij een administratiekantoor dat op haar beurt voor deze aandelen certificaten aan toonder danwel op naam uitgeeft.

De stelling dat verpanding van deze aandelen uitermate grote gevolgen kan hebben voor de semi-beslotenheid en de bescherming van de naamloze vennootschap spreekt eigenlijk voor zich. Met het bieden van de mogelijkheid tot verpanding van deze aandelen dient dan ook uiterst voorzichtig te worden omgespron-

367 In beginsel geldt dezelfde regeling, afgezien van een tekstueel verschil in de leden I van de artt. 89 en $198 \mathrm{BW}$, voor de verpanding van aandelen op naam in een besloten vennootschap als voor de verpanding van die aandelen in een naamloze vennootschap. Het verschil in de regelingen ligt verscholen in lid 3 van genoemde bepalingen. Hierop zal later in deze paragraaf worden ingegaan.

368 Zie R.P. Voogd, diss. p. 449 e.v. 
gen. In het meest ideale geval zou de verpanding van genoemde aandelen statutair uitgesloten dienen te zijn. De mogelijkheid hiertoe wordt, zoals reeds eerder opgemerkt ${ }^{369}$, geboden.

\section{a. Prioriteitsaandelen}

In beginsel zijn aan alle aandelen gelijke rechten verbonden, zo leren ons de artikelen 92 en 201 BW. De statuten kunnen echter andersluidende bepalingen inhouden. In $\S 17$ Departementale Richtlijnen 1986 lezen we:

"Het is geoorloofd statutair te bepalen dat aan zekere aandelen (prioriteitsaandelen) bepaalde machtsrechten zullen zijn verbonden die nauwkeurig in de statuten moeten zijn omschreven."

Een vennootschap zal deze op naam luidende aandelen, die zwaar geblokkeerd zijn en veelal gehouden worden door een stichting, hebben geplaatst teneinde de macht ${ }^{370}$ in de vennootschap te concentreren bij een selecte groep aandeelhouders. Van deze prioriteitsaandelen, benut in het kader van een oligarchische regeling, gaat zeker een beschermende werking uit. Een overnemer kan er in slagen een meerderheidspakket in de over te nemen vennootschap op te bouwen, echter, hij zal er voorshands niet in slagen binnen de vennootschap de dienst uit te maken, daar de meest essentiële bevoegdheden, zoals de benoeming van bestuurders, worden gecontroleerd door de vergadering van houders van prioriteitsaandelen. Het prioriteitsaandeel vertegenwoordigt veelal geen financieel belang, het heeft een duidelijk machtskarakter. Hierin ligt dan ook de besloten kern van de vennootschap. Gezien het feit dat het prioriteitsaandeel slechts een beperkt financieel belang in de vennootschap vertegenwoordigt, zal het zelden voorwerp van verpanding zijn. Sterker nog, vanwege het bijzondere machtskarakter van deze aandelen ligt uitsluiting van de mogelijkheid van verpanding voor de hand.

369 Zie § 1.3.3.3 en § II.7.3.

370 Voogd noemt in zijn dissertatie, verwijzend naar J.H.F.J. Cremers (Prioriteitsaandelen, diss.), de volgende prioriteitsrechten: bindende voordracht voor de benoeming van bestuurders en commissarissen, schorsing en ontslag van bestuurders en commissarissen (de bevoegdheid bestuurders te ontslaan is naar mijn mening in strijd met het bepaalde in de artt. 132 jo 134 $B W$ ), statutenwijziging en ontbinding. emissie van aandelen. Voorts noemt Voogd nog de volgende rechten die, blijkens een door hem gehouden statutenonderzoek, aan de prioriteit worden toegekend: het vaststellen van het aantal directeuren en commissarissen, het vaststellen van de bezoldiging van directeuren en commissarissen en het vormen van reserves. Zie R.P. Voogd, diss. p. 41. 


\section{b. Preferente beschermingsaandelen}

In tegenstelling tot de prioriteitsaandelen zullen preferente beschermingsaandelen wel als pandobject in aanmerking komen. In deze paragraaf staat de relatie tussen verpanding van preferente beschermingsaandelen en de beslotenheid van het samenwerkingsverband centraal. Hoe groot en verstrekkend de gevolgen kunnen zijn van executie van een in pand gegeven pakket aandelen wordt duidelijk indien men zich realiseert dat bijvoorbeeld ter financiering van een constructie waarbij een groot pakket preferente beschermingsaandelen wordt geplaatst, het hele pakket prefs veelal ter meerdere zekerheid aan de financier zal worden verpand. Verzuimt de eigenaar van de prefs zijn verplichtingen jegens de financier na te komen, dan is deze laatste - in principe - vrij de aan hem in pand gegeven aandelen te verkopen aan derden. Het beschermend karakter van de prefs zal hiermee verdwenen zijn.

Alvorens in te gaan op de relatie tussen emissie van beschermingsprefs en pandrecht, kort iets over de constructie in het algemeen en het karakter van de preferente beschermingsaandelen in het bijzonder.

Emissie van preferente beschermingsaandelen komt veelvuldig voor. Men bedenke evenwel dat wanneer sprake is van daadwerkelijk geplaatste prefs er ook sprake zal zijn van een - feitelijke - overnamedreiging. De idee is dat de vennootschap die de dreiging van een overname voelt een pakket preferente aandelen plaatst bij een bevriende relatie, veelal een daartoe in het leven geroepen 'stichting continuïteit'. ${ }^{371}$ Deze stichting, dat wil zeggen het bestuur van de stichting, oefent het stemrecht verbonden aan de aandelen uit, en wel op een wijze die geheel overeenkomt met de (beschermings-)wensen van het bestuur van de uitgevende vennootschap. In wezen sorteert deze beschermingsconstructie pas echt effect wanneer het aantal uitgegeven preferente aandelen groter of gelijk is aan het totale aantal geëmitteerde gewone aandelen. Is dit het geval, dan kan een overnemer nooit meer dat de helft van het totaal aantal stemmen bemachtigen.

Waarom wordt nu bij deze constructie gebruik gemaakt van 'preferente aandelen'? In de eerste plaats delen deze aandelen slechts voor een bepaald - vooraf vastgesteld preferent - gedeelte in de winst van de vennootschap en geeft het aandeel daarenboven geen verder recht op winstdeling. Het preferente aandeel geeft evenmin recht op een gedeelte van het liquidatiesaldo. Hierdoor kunnen preferente aandelen a pari worden geplaatst. Omdat de aandelen niet worden uitgegeven ter vergroting van het geplaatste kapitaal, maar ter beïnvloeding van de zeggenschaps- en machtsstructuur binnen de vennootschap, luiden zij altijd op naam. Dit betekent op zijn beurt dat bij het nemen van deze aandelen - in

371 Door het beursbestuur worden enkele voorwaarden gesteld aan het bestuur van de stichting. Op deze plaats zal ik niet ingaan op deze voorwaarden. Verwezen zij naar Bijlage $X$ van het Fondsenreglement. 
beginsel - volstaan kan worden met een storting van $25 \%$ van de nominale waarde. ${ }^{3 n}$ Hierdoor wordt de financiële last die door de 'stichting continuïteit' dient te worden gedragen aanzienlijk verkleind. ${ }^{373}$ Toch zal met deze constructie, zeker wanneer het te emitteren pakket prefs even groot of zelfs groter is dan het pakket uitstaande gewone aandelen, een aanzienlijk bedrag gemoeid zijn, dat door de 'stichting continuïteit' op tafel dient te worden gelegd. Dit bedrag kan niet door de uitgevende instelling worden betaald, ook kan zij dit bedrag niet aan de stichting schenken. Hiertegen verzet zich art. 98c BW. De stichting zal dus een financier moeten zoeken, die bereid is het betreffende krediet aan haar te verlenen. Echter, de kredietverschaffer zal zekerheid bedingen van de stichting. Ook hier kan de uitgevende vennootschap zich niet sterk maken voor haar beschermengel. Immers, het garant staan en het stellen van een borg valt eveneens onder de werking van art. 98c BW. De zekerheid zal dus gevonden moeten worden bij de stichting zelf. Verpanding van het pakket preferente beschermingsaandelen biedt uitkomst. De relatie verpanding en prefs is gelegd.

In het algemeen zou men moeten oordelen dat verpanding van preferente beschermingsaandelen geen geweldige optie is. Echter, het is zeker niet ondenkbaar dat de 'stichting continuïteit', teneinde te kunnen voldoen aan de minimale stortingsplicht van $25 \%$ nominaal, het pakket preferente aandelen aan een kredietverschaffer moet verpanden om zo aan de benodigde liquiditeiten te komen. ${ }^{374}$ Het stemrecht verbonden aan deze aandelen zal te allen tijde bij het bestuur van de stichting - de aandeelhouder - blijven berusten. Is dit immers niet het geval en gaat het stemrecht, ten gevolge van een statutaire bepaling danwel ten gevolge van een daartoe strekkende bepaling in de vestigingsakte van het pandrecht, over op de pandhouder, dan wordt het beschermend karakter van de uitgegeven preferente aandelen gefrustreerd. Blijft het stemrecht in handen van de stichting dan lijkt een bevredigende situatie te zijn ontstaan. Enerzijds hoeft de stichting geen financiële escapades te ondernemen, anderzijds wordt de beoogde bescherming niet aangetast. Er zit evenwel een adder onder het gras. Stel dat de stichting niet in staat is aan zijn financiële verplichtingen te voldoen, omdat zij bijvoorbeeld moet gaan procederen tegen de vennootschap. Zij verzuimt herhaaldelijk de overeengekomen rente-afdrachten te voldoen. ${ }^{375}$ Onder deze omstandigheden zal

372 Zie art. 80 lid $1 \mathrm{BW}$.

373 Althans in beginsel. Het obligo, bestaande uit $75 \%$ van de nominale waarde van de aandelen, blijft als latente schuld op de stichting rusten. Het kan niet worden kwijtgescholden en kan te allen tijde door de vennootschap (of door de curator in faillissement) worden opgevraagd.

374 Gezien het beoogd beschermend effect van de preferente aandelen, zou men moeten concluderen dat verpanding van deze aandelen niet strookt met de ratio en strekking van de maatregel. Echter, in de praktijk zal een verbod tot verpanding veelal bezwaarlijk zijn omwille van bovengenoemde reden.

375 Veelal wordt bij het gebruik van de beschermingsprefs bepaald, dat het te betalen dividend op deze aandelen - ongeveer - gelijk zal zijn aan de grootte van het bedrag dat de houder van die aandelen in de vorm van rente zal moeten betalen aan diens geldschieter. 
de bank over kunnen gaan tot executie van het pand. Op dat moment kan zich een aantal situaties voordoen. In de eerste plaats is denkbaar dat de bank de prefs executeert overeenkomstig de daarvoor geldende wettelijke bepalingen. De preferente aandelen worden gekocht door een - willekeurige - (rechts)persoon. De bescherming is op dat moment weg. Maar het gevaar van overname van de uitgevende vennootschap is nog niet meteen aan de orde.

Worden de preferente aandelen evenwel gekocht door een persoon die reeds een aanzienlijk belang in de uitgevende vennootschap heeft opgebouwd, wellicht degene wiens overnamedreiging ten grondslag aan de beschermingsconstructie lag, dan is het gevaar van een dreigende overname plotseling niet meer zo latent als in het vorige geval. ${ }^{376}$

In de praktijk wordt, in het kader van de gecontroleerde overdracht van aandelen, veelal gebruik gemaakt van een aanbiedingsblokkade. Stel dat in de statuten van de uitgevende vennootschap een aanbiedingsblokkade is opgenomen voor de overdracht van de preferente aandelen. Gezien het feit dat er veelal maar een houder van preferente aandelen zal zijn en er dus geen reflectie zal plaatsvinden, het aanbieden van preferente aandelen aan de houders van - gewone - aandelen de bescherming doorbreekt en het bestuur geen potentiële gegadigde voor de overname van de aandelen zal kunnen aanwijzen, kan de verkoop van de preferente aandelen doorgang vinden, hetgeen zal leiden tot het ter ziele gaan van de beschermingsconstructie en wellicht tot overname van de vennootschap.

Is er statutair een goedkeuringsblokkade aangebracht dan zal het daartoe aangewezen orgaan, de houder van de preferente beschermingsaandelen, geen goedkeuring verlenen aan de overdracht, zodat de pandhouder vrij is de aandelen te verkopen aan een derde partij. De kans dat deze partij de reden vormde voor het opwerpen van de beschermingswal is niet denkbeeldig. Zowel in geval van een aanbiedings- als van een goedkeuringsblokkade kan het orgaan, onder weigering van goedkeuring, andere gegadigden aanwijzen aan wie de verpande aandelen tegen contante betaling kunnen worden aangeboden. Op deze wijze hoeft de beschermende werking van de prefs niet verloren te gaan. ${ }^{3 n}$ Echter, indien men bedenkt dat het pakket preferente beschermingsaandelen even groot of zelfs

376 Het is mijns inziens zeer wel denkbaar dat, op het moment waarop het in pand gegeven pakket beschermingsaandelen geẻxecuteerd wordt, de vennootschap over zal gaan tot het opvragen van het obligo. Dit zal zeker gebeuren indien de vennootschap in staat van faillissement komt. Het feit dat op de koper van de preferente aandelen een stortingsplicht (groot $75 \%$ ) komt te rusten, zal naar mijn mening een zekere bescherming met zich mee brengen. Immers, het gaat om een aanzienlijk bedrag.

377 Denkbaar is dat een tweede stichning in het leven wordt geroepen die de preferente aandelen overneemt, en die ten gevolge daarvan in het zelfde - financiële - schuitje terecht kan komen als waarin de eerste stichting momenteel zit. Met toestemming van de aandeelhouder (stichting) kan ook de uitgevende vennootschap als gegadigde optreden. Hierbij zal de vennootschap echter de grens in ogenschouw moeten nemen die gesteld wordt aan de inkoop van eigen aandelen. 
groter is dan het totaal van het geplaatste kapitaal, zal het vinden van zo'n redder in de nood geen eenvoudige klus zijn. Vooral niet omdat, gezien het gegeven dat de vennootschap gedwongen is het preferent dividend te passeren, die vennootschap geen interessant beleggingsobject zal vormen.

Verpanding van preferente beschermingsprefs kan dus - onder bepaalde omstandigheden - leiden tot een doorbraak van het besloten karakter van de vennootschap.

\section{c. Certificering van aandelen}

In paragraaf $\mathrm{I} .10$ ging ik in op het - wettelijk - pandrecht van certificaathouders en de certificeringsconstructie in het algemeen. Aandacht werd besteed aan de vraag wanneer gesproken kan worden van medewerking van de vennootschap aan de certificering van aandelen. Besproken werd wanneer het wettelijk pandrecht wel en wanneer het niet ontstaat. Tevens werd een relatie gelegd tussen het wettelijk pandrecht en het tot stand komen van bepaalde lidmaatschapsrechten voor de certificaathouder/pandhouder. In deze paragraaf zal de vraag centraal staan of ten gevolge van het wettelijk pandrecht van art. 3:259 BW de besloten kern van de extern open naamloze vennootschap teloor kan gaan.

Het wettelijk pandrecht geeft certificaathouders de bevoegdheid in geval van nietuitbetaling van het hun verschuldigde het pand geheel of gedeeltelijk te doen verkopen en zich uit de opbrengst te voldoen. De wijze waarop dit dient plaats te vinden wordt beschreven in art. 3:259 lid $3 \mathrm{BW}$.

Stel dat op een zeker moment het administratiekantoor niet langer kan voldoen aan de uitbetaling van hetgeen aan de certificaathouders verschuldigd is. De certificaathouders kunnen op dat moment overgaan tot executie van het pand, i.e. de aandelen die gehouden worden door het administratiekantoor. Hiertoe wenden de certificaathouders zich tot de president van de rechtbank in de woonplaats van de vennootschap die de certificaten heeft doen uitgeven. Zij verzoeken hem een bewindvoerder over de aandelen te benoemen, die voor de verkoop en de verdeling van de opbrengst zorgdraagt. De bewindvoerder is verplicht om bij de verkoop van de aandelen de statutaire blokkeringsregeling in acht te nemen. ${ }^{378}$ Dit wil zeggen dat hij, in geval van een aanbiedingsregeling 379 , de aandelen moet aanbieden aan de (overige) houders van aandelen op naam. De vraag is nu

378 Dit vloeit voort uit art. 2:198 lid 5 BW. Zie ook F.J.P. van den Ingh, diss. p. 189 en de in noot 121 (p. 189) aangehaalde literatuur.

379 In geval van een statutaire goedkeuringsregeling zal het goedkeurend orgaan de vergadering van houders van aandelen op naam zijn, dit is het administratiekantoor. Zij zal haar goedkeuring aan de voorgenomen verkoop weigeren en zo mogelijk zichzelf als andere gegadigde aanwijzen. 
of dit aanbod zich ook richt tot het administratiekantoor. Het administratiekantoor zal veelal de enige houder van aandelen op naam zijn. Kan het kantoor reflecteren op het aanbod? Teneinde deze interessante vraag te beantwoorden zullen een tweetal situaties worden beschreven. In de eerste plaats het geval waarin het administratiekantoor ten gevolge van royement van de certificaten overgaat tot aanbieding van de aandelen. Richt in dit geval het aanbod zich ook tot het AK en, zo ja, mag het AK op dit aanbod reflecteren? In de tweede plaats wordt bezien of in het geval van executie van het wettelijk pandrecht ten behoeve van de houders van bewilligde certificaten de hiervoor gestelde vragen op gelijke wijze beantwoordt kunnen worden. ${ }^{380}$

\section{Aanbod ten gevolge van royement}

In het geval waarin aandelen op naam, wier overdracht door middel van een statutaire aanbiedingsregeling is beperkt, zijn gecertificeerd kan in de administratie-overeenkomst tussen AK en houder van certificaten worden bepaald dat de certificaten niet, beperkt, danwel volledig royeerbaar zijn. Zijn de certificaten niet royeerbaar, dan zal zich het probleem van het aanbod ten gevolge van royement niet voordoen. Verdedigd wordt door Van den Ingh dat de houder van een niet royeerbaar certificaat wel het recht heeft op omwisseling van het door hem gehouden stuk indien het $\mathrm{AK}$ zijn beheerstaak beëindigt. Het recht op omwisseling vloeit volgens schrijver voort "uit de economische gerechtigdheid

380 Mijns inziens ligt aan de beantwoording van deze vraag nog een andere vraag ten grondslag, namelijk de vraag op welke wijze het medewerkingscriterium dient te worden uitgelegd. C.A. Schwarz merkt in zijn bijdrage voor TVVS $1992 \mathrm{nr}$. 1 (Enkele vragen bij de certificering van aandelen) het volgende op: "Over het antwoord op de vraag wat medewerking aan de certificering inhoudt, zijn de meningen verdeeld. Als ik het goed zie, is dit een gevolg van twee verschillende invalshoeken, van waaruit naar dit medewerkingscriterium wordt gekeken." De twee zienswijzen die in deze verdedigd worden houden enerzijds een nuime en anderijds een enge interpretatie van het medewerkingscriterium in. Eng is de interpretatie waarbij uitgegaan wordt van het belang van de vennootschap waar, met name bij de besloten vennootschap, wordt gewezen op het wettelijk voorgeschreven besloten karakter van dit samenwerkingsverband. Daarentegen kan het medewerkingscriterium ook worden benaderd vanuit de belangen van de certificaathouders, wier positie jegens de vennootschap wordt versterkt. Deze opvatting vraagt: voor een ruime uitleg van de medewerkingseis. Zie over deze materie $F$.J.P. van den Ingh, diss. \$ 4.4; C.A. Schwarz. TVVS 1992, p. 7 en F.J.P. van den Ingh, Een andere kijk op enkele problemen bij certificering van aandelen, TVVS 1992 , p. 77. Zie ook $\$ 1.10 .3-4$. Naar mijn mening speelt de vraag welke belangen primair behartigd dienen te worden, die van de vennootschap of die van de certificaathouders, een grote rol bij de beantwoording van de vraag of het AK gerechtigd is te reflecteren op de door haar aangeboden aandelen, dan wel of het aanbod van de aandelen bij executie zich mede tot het AK richt. 
van de certificaathouder tot een aan het certificaat ten grondslag liggend aandeel ${ }^{n} .381$

Ten gevolge van royering door de certificaathouder zal het AK de aan het certificaat ten grondslag liggende aandelen, danwel gedeelten daarvan, ten titel van beëindiging van beheer ${ }^{382}$ aan de certificaathouder moeten overdragen. Geldt ten aanzien van de over te dragen aandelen echter een statutaire aanbiedingsverplichting, dan zal het $\mathrm{AK}$, alvorens deze aandelen over te dragen aan de royerende certificaathouder, de aandelen eerst moeten aanbieden aan de 'overige' aandeelhouders. De vragen die hier nu aan de orde zijn, zijn of dit aanbod zich ook richt tot het aanbiedend AK zelf en, bij een bevestigende beantwoording van deze vraag, of het AK gerechtigd is te reflecteren op dit aanbod.

De eerste vraag wordt in de literatuur in het algemeen bevestigend beantwoord. ${ }^{383}$ Als argument voor aanvaarding van de stelling dat het door het AK gedane aanbod zich mede richt tot het aanbiedend AK zelf voert Schwarz ${ }^{384}$ aan:

"Het sterkste argument voor bevestigende beantwoording van deze voorvraag is, dat de aanbiedingsregeling gecreëerd is ter bescherming van het besloten samenwerkingsverband van aandeelhouders."

Schrijver lijkt er dus van uit te gaan dat het meest zwaarwegende argument pro 'aanbieding mede aan het $\mathrm{AK}$ ' is gelegen in het waarborgen van het besloten karakter van de vennootschap. Dat schrijver dit argument gebruikt is, in genoemd kader, goed denkbaar. Immers, een van de voornaamste redenen die ten grondslag ligt aan het hanteren van de certificeringsconstructie is het beschermen van de beslotenheid van het samenwerkingsverband. In de situatie waarin het AK de

381 F.J.P. van den Ingh, diss. p. 78-79. In dit kader wordt door Van den Ingh, diss. p. 172 opgemerkt: "Ten slotte vloeit uit de economische gerechtigdheid tot het onderliggend aandeel voor dat in beginsel een conversierecht ten gunste van de certificaathouders ontstaat na beëindiging van de beheersovereenkomst." In noot 59, p. 172, vervolgt schrijver zijn betoog. "Alleen bij cerificering tegen aandelen kan men zeggen dat de gerechtigdheid tot de aandelen terugkeert bij de aandeelhouders die hebben gecertificeerd resp. bij hun rechtsopvolgers. Bij certificering tegen contanten kan van een dergelijke terugkeer geen sprake zijn, aangezien de aandelen destijds rechtstreeks aan het AK zijn uitgegeven."

382 F.J.P. van den Ingh, diss. p. 80.

383 C.A. Schwart. TVVS 1992, p. 8 en zijn verwijzing naar $L$. Timmerman, De beslotenheid nader beschouwd, TVVS 1975 , p. 248 en F.J.P. van den Ingh, diss. p. 122. In eerste instantie opteen Schwarz voor een kritische benadering van het probleem, later beantwoordt hij de vraag echter volmondig positief.

384 C.A. Schwar, TVVS 1992, p. 8. Schrijver geeft (t.a.p. p. 8 en 9) nog een tweetal andere argumenten voor het standpunt dat het aanbod door het AK zich tevens tot datzelfde AK richt. Hij verwijst hierbij naar het arrest van Hof 's-Hertogenbosch, 28 mei 1957, NJ 1958, 129 en HR 11 april 1958, NJ 1958, 302 (Schellens/Schellens). 
enige houder van aandelen op naam is, zou een negatieve beantwoording van de vraag de teloorgang van het besloten karakter van het samenwerkingsverband teweegbrengen. Het royement door de certificaathouder heeft de overdracht, ten titel van beëindiging van het beheer, van het onderliggend aandeel tot gevolg. Door het feit dat de certificaathouder aandelen verkrijgt, dringt hij binnen in het in beginsel besloten - samenwerkingsverband van aandeelhouders. Met Schwarz ben ik dan ook van mening dat 'een aanbod dat zich mede tot het aanbiedend AK zelf richt' een mogelijkheid biedt ter intensivering van het beschermend karakter van de constructie. Mijns inziens moet men zich echter afvragen of dit argument, zonder nadere motivering, ook rechtens houdbaar is. Bezien wij de volgende casus:

NV X heeft ter bescherming alle aandelen op naam geplaatst bij een administratiekantoor. Naast het AK is er geen andere houder van aandelen op naam in de NV X. Y houdt een groot pakket certificaten van aandelen $X$ en wenst op enig moment zijn certificaten te royeren. Alvorens het royement plaats kan vinden dient het $\mathrm{AK}$ de aandelen aan te bieden aan de 'overige' aandeelhouders conform de statutaire aanbiedingsblokkade van NV X. Gezien het feit dat het AK niet bepaald staat te springen $Y$ als mede-aandeelhouder te verwelkomen stelt het zich op het standpunt dat het gedane aanbod aan de 'overige' aandeelhouders, mede inhoudt een aanbod aan het aanbiedend AK zelf.

Is deze stelling zonder meer houdbaar? Ik ben geneigd deze vraag, met een beroep op het algemeen verbintenissenrecht, ontkennend te beantwoorden. De intentie van de aanbiedingsverplichting ziet onder andere op het feit dat er een overeenkomst tot stand wordt gebracht tussen de aanbiedende aandeelhouder en de aandeelhouder die het aanbod aanvaard. Deze overeenkomst zal ontstaan ten gevolge van een wilsovereenstemming, die aldus moet worden geïnterpreteerd dat de ene partij een aanbod doet dat door de andere partij wordt aangenomen. ${ }^{385}$ Het kan toch niet zo zijn dat het AK, in de hoedanigheid van houder van aandelen, een aanbod aan zichzelf doet, nog los van de vraag of hij dit aanbod überhaupt zal kunnen aanvaarden. ${ }^{386}$

385 Asser-Hartkamp II, nr. 135; "Onder aanbod wordt dan verstaan: een aan de wederpartij gedaan voorstel tot het aangaan van een overeenkomst, welk voorstel zodanig is bepaald dat door de aanvaarding daarvan onmiddellijk een overeenkomst bestaat."

386 Als ik het goed zie doet zich hier een geval voor als omschreven in het eerste lid art. 6:161. Indien een aandeelhouder aandelen die hij zelf houdt aan zichzelf aanbied en dit aanbod vervolgens aanvaard vindt een vermenging plaats van de kwaliteiten schuldeiser en schuldenaar. Volgens genoemd artikel leidt dit tot het tenietgaan van de verbintenis. 
Van den Ingh kiest voor een andere benadering van deze 'voorvraag'. Hij stelt $^{387}$ :

"Het AK is te beschouwen als een persoon die in eigen naam, maar voor rekening van anderen handelt. Het is heel goed mogelijk dat het AK voor rekening van de ene certificaathouder aandelen aanbiedt en voor rekening van een andere certificaathouder reflecteert."

Schrijver brengt hier het wapen van de middellijke vertegenwoordiging in de strijd. In zijn visie behartigt het $\mathrm{AK}$ enerzijds de belangen van de royerende certificaathouder, door de aandelen waarop het royement betrekking heeft aan te bieden, anderzijds treedt het AK op voor de andere certificaathouders voor wie hij het aanbod aanvaardt. Hoe moeten wij dit rechtens zien? In welke hoedanigheid biedt het $\mathrm{AK}$ aan en in welke hoedanigheid reflecteert hij? Welke c.q. wiens rechten worden door het $\mathrm{AK}$ uitgeoefend? De aanbieding geschiedt door het $\mathrm{AK}$ als aandeelhouder. Hij dient aan te bieden aan de 'overige' aandeelhouders. Die zijn er echter in het gegeven geval niet. Dient het AK dan te reflecteren als aandeelhouder, namens andere certificaathouders? Maakt het verschil wanneer men de situatie zou zien als een reflecterend $A K$ op basis van de wensen van de certificaathouders wier belangen worden behartigd? Naar mijn mening dient gesteld te worden dat de omstandigheid dat het AK optreedt als middellijke vertegenwoordiger van zowel de royerende certificaathouder als de overige houders niet kan leiden tot een andere visie op het gegeven probleem. In beide gevallen treedt het $\mathrm{AK}$ op als aandeelhouder. Mijns inziens kan het AK niet voor rekening van de 'andere' certificaathouders reflecteren vanwege het feit dat zij geen recht hebben op reflectie. $\mathrm{Zij}$ behoren immers niet tot de kring tot wie het aanbod (van de aandelen) gericht is. ${ }^{388}$

Met betrekking tot de vraag of het AK gerechtigd is te reflecteren op de aangeboden aandelen kan het volgende worden opgemerkt. Ondanks het feit dat Schwarz de mening is toegedaan dat het aanbod van het AK zich ook tot het AK zelf richt, beantwoordt hij de vraag of het AK mag reflecteren negatief. Hij stelt:

"Beantwoording van deze vraag lijkt eenvoudig nu de rechtsverhouding, die aanleiding tot
de voorgenomen overdracht geeft, het AK steeds het recht op reflectie lijkt te ontzeggen.
Het beheer wordt beêindigd hetzij doordat de certificaathouder gebriikt maakt van zijn
conversierecht, hetzij om andere redenen, (...). In alle gevallen zal de beëindiging van het
beheer plaatsvinden uit hoofde van een overeenkomst tussen certificaathouder en AK.
Indien nu het AK zou reflecteren op de in het kader van de voorgenomen overdracht
aangethoden aandelen, zou daarmee de overdracht van de aandelen aan de certificaathouder
worden gefrustreerd. Er zou alsdan sprake zijn van een handelen in strijd met de redelijk-

387 F.J.P. van den Ingh, TVVS 1992, p. 77.

388 Mijns inziens spreekt F.J.P. van den Ingh (TVVS 1992, p. 78) dan ook ten onrechte over een aan de certificaathouders toekomend 'indirect reflectierecht'. 
heid en billijkheid die het AK jegens de certificaathouders in acht moet nemen, terwijl het gebruikmaken van de reflectiebevoegdheid misbruik van recht zou opleveren. (...)

De kwestie overdenkend zou ik menen dat het $\mathrm{AK}$, bij royering van certificaten, nimmer gebruik mag maken van het hem toekomend reflectierecht. Indien de mogelijkheid tot conversie in de administratievoorwaarden is voorzien, gaat het niet aan dat het AK de mogelijkheid van verkrijging van de aandelen door de certificaathouder breidelt, ongeacht de vraag of de certificering al dan niet tegen contanten heeft plaatsgevonden en ongeacht de belangen van de overige certificaathouders. Bij het nemen van de certificaten was hen de inhoud van de voorwaarden bekend. ${ }^{\text {n389 }}$

Schrijver is dus de mening toegedaan dat, ten gevolge van het feit dat het aanbod zich mede richt tot het aanbiedend $\mathrm{AK}$, het $\mathrm{AK}$ wel een reflectierecht heeft maar dit, gezien de rechtsverhouding tussen $\mathrm{AK}$ en certificaathouder en ongeacht de belangen van andere certificaathouders, niet mag uitoefenen.

Door Van den Ingh wordt de vraag naar het bestaan van het reflectierecht - of moeten wij, in zijn visie, spreken over een reflectieplicht - op een andere wijze benaderd. Schrijver meent onderscheid te moeten maken tussen gevallen van gedeeltelijke en volledige certificering. Van den Ingh ${ }^{390}$ stelt:

"In het eerste geval (gedeeltelijke certificering; $\mathrm{JH}$ ) wordt nogal eens in de administratievoorwaarden bepaald dat het $\mathrm{AK}$ op bet in het kader van de blokkeringsregeling aangeboden aandelen dient te reflecteren, indien de certificaathouders de wens te kennen geven om van de aangeboden aandelen certificaten te verkrijgen. Gebeurt dit laatste, dan staat het AK voor het dilemma de rangorde te bepalen tussen de verplichting jegens de royerende certificaathouder om aan royement mede te werken en zich dus van reflectie te onthouden en de verplichting jegens de overige certificaathouders om wel te reflecteren.

In het tweede geval (volledige certificering; $\mathrm{JH}$ ) ontbreekt meestal een bepaling als hiervoor bedoeld, doch daarmee is botsing van rechtsplichten nog niet uitgesloten! (...)

Welke rechtsplicht weegt nu zwaarder? Ik zou menen dat het belang van de certificaathouder die gerechtigd is de rechtsverhouding met het AK te beëindigen zwaarder dient te wegen dan het belang van de overige certificaathouders om hun rechtsverhouding met het AK (en indirect ook met de vennootschap) te intensiveren."

Aan de vraag of het AK gerechtigd is te reflecteren op de, door hemzelf, aangeboden aandelen komt men naar mijn mening niet toe indien, op basis van de hiervoor aangegeven gronden, de voorvraag ontkennend wordt beantwoord.

389 C.A. Schwarz, TVVS 1992, p. 9.

390 F.J.P. van den Ingh, TVVS 1992, p. 78. Zie ook F.J.P. van den Ingh, diss. p. 81 alwaar schrijver stelt: "Geldt een aanbiedingsregeling, dan is het AK verplicht een te decertificeren aandeel eerst aan zijn mede-aandeelhouders aan te bieden." In noot 38 op de aangehaalde p. vervolgt schrijver zijn betoog: "Mijns inziens kan het AK niet reflecteren op basis van de overige aandelen die het houdt. Ziet men dit anders, dan zal het AK, gezien haar doelomschrijving, alleen kunnen reflecteren indien het ervan verzekerd is dat er gegadigden zijn voor de tegenover deze aandelen uit te geven certificaten." Van den Ingh lijkt dus te erkennen dat, onder gegeven omstandigheden, het AK wel bevoegd is te reflecteren. 
Naast de eerder genoemde argumenten die tegen een bevestigend antwoord van de voorvraag spreken, wijs ik op het feit dat een reflectie door het AK op de, door het AK zelf, aangeboden aandelen kan leiden tot wanprestatie. Immers, conform de afspraak in de administratievoorwaarden is de certificaathouder gerechtigd zijn certificaten, met inachtneming van de daarvoor geldende beperkingen, te converteren in aandelen. Indien het $\mathrm{AK}$ dit recht frustreert door reflectie zijnerzijds, wanpresteert hij in zijn contractuele relatie jegens de certificaathouder.

Concluderend zou ik willen stellen dat het aanbod van aandelen door een $\mathrm{AK}$, in een geval waarin een certificaathouder over gaat tot royering van zijn certificaten, zich nimmer tot het aanbiedend $\mathrm{AK}$ richt. De stellingname dat het $\mathrm{AK}$, in dit geval, ook geen reflectierecht heeft behoeft naar mijn mening dan ook geen betoog. In dit kader ben ik met Van den Ingh van mening het AK slechts dan een reflectierecht (-plicht) ${ }^{391}$ heeft, indien door andere aandeelhouders dan het AK aandelen worden aangeboden. ${ }^{392}$

\section{Aanbod ten gevolge van executie van het wettelijk pandrecht}

Hiervoor wierp ik de vraag op of ten gevolge van de executie van het wettelijk pandrecht (art. 3:259 BW) de besloten kern van de gemengde vennootschap in gevaar zou kunnen komen. Indien het $\mathrm{AK}$ niet langer kan voldoen aan haar verplichtingen jegens de houders van certificaten, kunnen deze, zoals reeds eerder gezegd, zich wenden tot de president van de rechtbank met het verzoek een bewindvoerder aan te stellen die de verkoop van de aandelen in goede banen zal leiden.

Van den Ingh ${ }^{393}$ schrijft hierover:

"De verkoop door de bewindvoerder als wettelijk vertegenwoordiger van de certificaathouders (curs. $J H$ ) die met de verkoop hebben ingestemd, wordt beheerst door de algemene regels omtrent verkoop van een pand, te weten de art. 3:248-253. De verkoopopbrengst

391 Zie F.J.P. van den Ingh, TVVS 1992, p. 78.

392 Door C.A. Schwarz, TVVS 1992, p. 8-9 wordt verwezen naar de procedure Schellens/Schellens, Hof 's-Hertogenbosch, 28 mei 1957, NJ 1958, 129/ HR 11 april 1958, NJ 1958, 302. Voorts wordt door deze schrijver t.a.p. bepleit "dat een aandeelhouder, op grond van zijn resterend aandelenbezit, mag reflecteren op de door hem zelf aangeboden aandelen, (indien; $\mathrm{JH}$ ) de aandeelhouder die, door vererving, aandelen verkrijgt, terwijl de statuten verplichten tot aanbieding van aandelen, verkregen anders dan door overdracht. (...) Zo men al, met mij, zou willen aannemen dat het aanbod zich mede richt tot de aanbiedende aandeelhouder, dient in ieder geval te worden geconcludeerd dat slechts in bijzondere omstandigheden de aandeelhouder het reflectierecht toekoms." (curs.JH). Zie ook C.A. Schwar, Versterking van het beschermend effect van certificering van aandelen, WPNR 6104 (1993), p. 617-620.

393 F.J.P. van den Ingh, diss. p. 188. 
wordt door de bewindvoerder onder de betrokken certificaathouders verdeeld. Lid 3 (van art. 3:259 $\mathrm{BW} ; \mathrm{JH}$ ) bepaalt uitdrukkelijk dat hun rechten (jegens het $\mathrm{AK}$ ) door de verdeling teniet gaan."

Uit het vijfde lid van art. 198 BW vloeit voort dat ook de executerende bewindvoerder zich moet richten naar de wettelijke en statutaire bepalingen ten aanzien van de vervreemding en de overdracht van aandelen. ${ }^{344}$ Dit wil zeggen dat, indien de statuten van de uitgevende vennootschap een aanbiedingsblokkade kennen ten aanzien van de overdracht van aandelen op naam, de bewindvoerder, alvorens hij tot executie van het pand kan overgaan, de aandelen eerst moet aanbieden aan de overige aandeelhouders. In de praktijk zal het evenwel zo zijn dat er slechts één houder van gecertificeerde aandelen van een bepaalde soort ${ }^{395}$ is, namelijk het AK. Het feit dat de bewindvoerder, ter uitvoering van de statutaire blokkeringsregeling, de aandelen moet aanbieden aan de 'overige' aandeelhouders heeft in dit geval dus niets om het lijf. In deze lezing zou er dus een abrupt einde komen aan de beschermende werking van de certificeringsconstructie. Ook hier dient men zich dus af te vragen of het aanbod, in dit geval gedaan door de bewindvoerder, zich mede richt tot het AK en of het AK alsdan gerechtigd is op dit aanbod te reflecteren.

In mijn opvatting is de bewindvoerder vrij de aandelen aan iedere gegadigde over te dragen. In de andere opvatting, dus die waarin de executerende bewindvoerder de aandelen zou moeten aanbieden aan het administratiekantoor, zou zich de ongerijmdheid voordoen van de situatie waarin de aanbieding plaatsvindt aan degene onder wie wordt geëxecuteerd. In zo'n situatie blijkt trouwens ook een $x \%$-regeling geen effect te sorteren, immers, stel dat een bewindvoerder $20 \%$ van de onder het wettelijk pandrecht vallende aandelen executeert, terwijl een $1 \%$ regeling zou gelden, dan zou de overdracht van de aandelen aan het administratiekantoor geen mogelijkheid $z i j n^{396}$ terwijl de vennootschap niet tot inkoop van de aandelen zou kunnen overgaan. In dat geval zou dus van de bewindvoerder gevraagd moeten worden twintig natuurlijke personen te zoeken die allen bereid zijn $1 \%$ van de aandelen over te nemen. Met Schwarz ${ }^{397}$ ben ik van mening dat

394 Zie ook F.J.P. van den Ingh, diss. p. 102 en 189 en de aldaar aangehaalde literatuur.

395 Veelal zal het zo zijn dat de blokkeringsregelingen zien op aandelen van een bepaalde soort. Denkbaar is echter dat het statutaire reflectierecht bij aanbieding van aandelen $A$ aan de houders van aandelen $B$ is toegekend.

396 Niet vanwege de stantaire $1 \%$-regeling, het administratiekantoor zal in de voorkomende gevallen zijn vrijgesteld van de regeling, maar gezien het gegeven dat het kantoor, in de hoedanigheid van pandgever, niet zal kunnen reflecteren.

397 C.A. Schwar, WPNR 6104 (1993), p. 619. Schwarz merkt t.a.p. op: "De verkopend bewindvoerder zal zich in principe dienen te houden aan de beperkingen die de $1 \%$-regeling met zich brengt. Deze regeling zal verkoop van de aandelen veelal feitelijk onmogelijk maken nu inkoop door de vennootschap niet tot de mogelijkheden zal behoren (noot 17: zeker niet wan- 
een zodanige blokkeringsregeling de overdracht van aandelen uiterst bezwaarlijk, ja zelfs onmogelijk, maakt, op welke grond de executerend bewindvoerder dan ook de statutaire bepaling naast zich neer kan leggen. Hij zal dan ook in staat zijn, ondanks de $1 \%$-regeling, meer dan $1 \%$ van de aandelen aan de certificaathouders/pandhouders te doen verblijven.

Van den Ingh oppert de mogelijkheid dat, naast het AK, een tweede stichting in het leven wordt geroepen. Schrijver gebruikt deze constructie in het geval waarin voor de overdracht van certificaten een blokkeringsregeling geldt, waarmee men wil bewerkstelligen dat de kring van houders van certificaten een besloten karakter heeft. Van den Ingh stelt ${ }^{398}$ :

\begin{abstract}
"Soms bestaat er naast het AK een stichting, die is opgericht met het oog op het probleem dat een certificaathouder, die zijn certificaten wil of moet overdragen, binnen de vrije kring geen gegadigden kan vinden. Zo is het denkbaar, dat een werknemer die in het kader van werknemersparticipatie certificaten houdt, op grond van de beëindiging van zijn dienstverband tot aanbieding van zijn certificaten verplicht is, terwijl er geen werknemers zijn die tot aankoop van deze certificaten kunnen of willen overgaan. Alsdan kan een stichting tot bevordering van de verhandelbaarheid van certificaten van aandelen in BV X een regulerende functie vervullen. Bepaalt de blokkeringsregeling dat aanbieding aan de mede-certificaathouders tegen nominale waarde dient te geschieden, dan zal die bepaling ongetwijfeld bijdragen aan de bereidheid van laatstgenoemden om de certificaten over te nemen en daarmede aan de beslotenheid."
\end{abstract}

Waarom zou men Van den Ingh's voorstel niet projecteren op een situatie waarin een bewindvoerder, namens de certificaathouders, gaat executeren onder het AK enig aandeelhouder - dat niet langer in staat is aan zijn verplichtingen te voldoen. Indien men delicate vragen als "mag het AK reflecteren op een aanbod dat door haar zelf wordt gedaan, in geval er geen andere aandeelhouders zijn en/of handelt het $\mathrm{AK}$ in strijd met de redelijkheid en billijkheid jegens de certificaathouders indien zij gebruik maakt van haar reflectierecht en maakt het AK in zo'n geval misbruik van haar recht?" wil voorkomen, dan is naar mijn mening, in navolging van Van den Ingh, goed denkbaar dat er in geval van certificering van aandelen naast het $\mathrm{AK}$ een tweede rechtspersoon wordt opgericht, aan wie een of meerdere

$397 \rightarrow$

neer, in dit voorbeeld, een fiks antal certificaathouders met de verkoop instemt. Vgl. art. 2:98 lid 2.) en de bewindvoender geen serieuze mogelijkheden zal zien om voldoende geünteresseerde natuurlijke personen te vinden, die allemaal bereid zijn om $1 \%$ van de aandelen te kopen. Daamaast is het AK, als pandgever, geen potentieel koper. In zodanige situatie lijkt een beroep van de executerend bewindvoerder op de niet toepasselijkheid van de $1 \%$-regeling in dit geval, op grond van de derogerende werking van de redelijkheid en billijkheid (noot 18: Vgl. HR 19 maart 1976, NJ 1978, 52 (nt. Wachter) en de noot van Scholten bij HR 15 juli 1968, NJ 1969, 101.), uiterst kansrijk."

398 F.J.P. van den Ingh, diss. p. 130. 
aandelen worden uitgegeven. ${ }^{399}$ Stel nu dat op enig moment het AK niet meer aan haar verplichtingen jegens de houders van certificaten kan voldoen en de certificaathouders, door middel van een bewindvoerder, hun wettelijk pandrecht gaan executeren, dan zal de bewindvoerder, conform de statutaire blokkeringsregeling, de te executeren aandelen eerst dienen aan te bieden aan de 'overige' aandeelhouders. Op dit punt stuitte men op de reeds beschreven problemen. In dit geval echter, is er geen sprake van enig probleem. De bewindvoerder biedt de aandelen aan aan de 'andere' houder van aandelen. Deze zal op zijn beurt gerechtigd zijn te reflecteren en, ervan uitgaande dat de financiële positie van deze aandeelhouder dit toestaat, de aandelen in eigendom te verwerven. De certificaathouders ontvangen dan een bepaald bedrag aan contanten en hun rechtsverhouding met het $\mathrm{AK}$, gaat teniet. De 'andere' aandeelhouder kan de verkregen aandelen certificeren, danwel overdragen aan het AK. Op deze manier blijft de kring van houders van aandelen in de gemengde vennootschap besloten. ${ }^{400}$ Men lette er op dat het hiervoor beschreven probleem zich alleen kan voordoen in het geval waarin de statuten van de vennootschap een aanbiedingsblokkade in combinatie met een $1 \%$-regeling kennen. Een statutaire combinatie van een $1 \%$-regeling met een goedkeuringsblokkade zou deze problemen kunnen voorkomen.

Mijns inziens is de oplossing die door Van den Ingh en Schwarz wordt aangedragen, waarbij wordt voorgesteld een tweede stichting op te richten die een of meer aandelen (danwel certificaten) in het kapitaal van de gemengde vennootschap houdt en aldus fungeert als 'andere' aandeelhouder, de enige mogelijkheid om, zowel in geval van conversie door de certificaathouder als executie door de bewindvoerder, de besloten kern van de gemengde naamloze vennootschap te behouden.

Aan het einde van deze paragraaf nog een opmerking aan het adres van de kritische practici. Zij kunnen immers het standpunt innemen dat de gegeven oplossing wellicht erg aardig is, maar geen uitkomst biedt indien het royeringsen/of executieproces reeds een aanvang genomen heeft. In deze stelling ligt een kem van waarheid verscholen. Er is mijns inziens nog een andere uitweg mogelijk waardoor het besloten karakter van de gemengde vennootschap gewaarborgd wordt. Kan de bewindvoerder de aandelen niet aanbieden aan de overige houders van aandelen op naam, simpel vanwege het feit dat die er niet zijn, dan dient een andere gegadigde te worden aangewezen door het daartoe bevoegde orgaan. Dit zal veelal de vergadering van houders van (gecertificeerde) aandelen op naam zijn, het administratiekantoor dus. Het administratiekantoor kan een

399 Deze aandelen zouden ook gecertificeerd kunnen worden.

400 Zie in gelijke zin C.A. Schwar, WPNR 6104 (1993), p. 617-620. 
bevriende relatie aanwijzen die, als gegadigde, in staat is de aan te bieden aandelen over te nemen. De besloten kern van de naamloze vennootschap wordt alsdan beschermo.

Tenslotte lijkt mij dat het nimmer de bedoeling zal zijn het stemrecht op gecertificeerde aandelen over te dragen aan derden, zoals bijvoorbeeld pandhouders op die aandelen. Derhalve zal steeds een verbod van overdracht van stemrecht op gecertificeerde aandelen moeten zijn gecreëerd. In geval van een volledige certificering zou dit kunnen geschieden door de mogelijkheid van overdracht van het stemrecht bij vestiging van het pandrecht in de statuten van de vennootschap uit te sluiten. In geval van een deelcertificering, waarin in de statuten van de vennootschap betrekkelijk deze aandelen zo'n verbod niet is opgenomen, zal dit verbod in de statuten van het administratiekantoor kunnen worden neergelegd.

\section{II.7.5 Gevolgen van stil pandrecht voor de beslotenheid van het samenwer- kingsverband}

In $\S$ 1.5.2.1. werd kort aandacht besteed aan de vraag naar de mogelijkheid van de vestiging van een stil pandrecht op aandelen op naam in een besloten vennootschap en in een niet beursgenoteerde naamloze vennootschap. Verdedigd werd aldaar dat, ten gevolge van een analoge toepassing van art. $86 \mathrm{c}$ lid 4 jo 89 lid 6 $B W$, een stil pandrecht gevestigd kan worden op aandelen op naam in besloten vennootschappen en niet beursgenoteerde naamloze vennootschappen. De vraag die zich nu aandient is of het vestigen van zo'n stil pandrecht gevolgen met zich mee brengt voor het besloten karakter van het samenwerkingsverband. Kan de vestiging van een stil pandrecht leiden tot doorbraak van de beslotenheid van de vennootschap, doordat de houder van een stil pandrecht stemrecht verkrijgt in de algemene vergadering van aandeelhouders? Getracht wordt deze vraag te beantwoorden tegen de achtergrond van de drie hiervoor geschetste samenwerkingsverbanden.

\section{a. De open naamloze vennootschap}

Binnen deze categorie kan een tweedeling worden gemaakt. Enerzijds is daar de gewone open naamloze vennootschap, anderzijds de beursnoterende open naamloze vennootschap. Voor deze laatste variant bepaalt de wet expliciet in art. $86 \mathrm{c}$ lid $4 \mathrm{BW}$ dat een pandrecht op aandelen in haar kapitaal kan worden gevestigd zonder erkenning door of betekening aan de vennootschap. Het stille pandrecht behoeft niet gevestigd te worden bij notariële akte. Een geregistreerde onderhandse akte volstaat. Voor de stille verpanding van aandelen op naam in een gewone naamloze vennootschap schets de wet geen aparte regeling. Verdedigd werd dat stille verpanding hier ook mogelijk is. Evenwel dienen hierbij kanttekeningen te worden geplaatst. De vestiging van het stille pandrecht dient mijns 
inziens te geschieden bij notariële akte. Zou men immers deze eis niet stellen dan kan het wettelijke regime van de registratie eenvoudig worden ontdoken door geen gewoon, maar een stil pandrecht op de aandelen te vestigen.

In art. 89 lid $6 \mathrm{BW}$ wordt bepaald dat, wanneer op aandelen een stil pandrecht is gevestigd, de pandhouder de rechten verbonden aan het aandeel eerst na erkenning door of betekening aan de vennootschap kan uitoefenen.

Al eerder werd opgemerkt dat het aspect van de beslotenheid van het samenwerkingsverband zowel bij de beursgenoteerde open naamloze vennootschap als bij de gewone open vennootschap in het algemeen geen rol van betekenis zal spelen. Wat is nu rechtens ten aanzien van de vraag wanneer de houder van het stille pandrecht gerechtigd is tot het uitoefenen van het stemrecht verbonden aan de verpande aandelen?

Ervan uitgaande dat de door mij verdedigde stelling, dat ook op aandelen op naam in een niet-beursgenoteerde naamloze vennootschap een stil pandrecht gevestigd kan worden, houdbaar is, komt het mij voor dat de houder van een stil pandrecht op aandelen op naam in al dan niet beursgenoteerde naamloze vennootschappen slechts dan stemrecht kan verkrijgen indien het stille pandrecht, ten gevolge van erkenning door danwel betekening aan de vennootschap, openbaar is geworden. ${ }^{401}$ Echter, het openbaar worden van het pandrecht betekent naar mijn mening niet automatisch dat de pandhouder het stemrecht kan uitoefenen. De vraag of de pandhouder stemrecht kan uitoefenen is namelijk afhankelijk van hetgeen terzake in de pandakte is opgenomen en de statutaire bepalingen hieromtrent. Ik ben van mening dat de statuten van zowel de beursgenoteerde open naamloze vennootschap als die van een gewone open naamloze vennootschap een breed scala van regelingen ten aanzien van het uit te oefenen stemrecht verbonden aan de verpande aandelen kunnen bevatten. Art. 89 lid 3 BW biedt hiertoe de mogelijkheid. Zoals reeds eerder vermeld kunnen de statuten van een naamloze vennootschap - beursgenoteerd of niet - bepalen dat het stemrecht te allen tijde bij de aandeelhouder/pandgever blijft. In het licht van de eerder gemaakte opmerking dat het aspect van de beslotenheid bij deze vennootschap in beginsel geen rol van betekenis speelt, zal dit statutaire voorbehoud niet snel nodig zijn. In het algemeen zal de regeling van art. 89 lid $3 \mathrm{BW}$ gevolgd worden. Dit betekent dat er drie scenario's denkbaar zijn.

In de eerste plaats kan de houder van het stille pandrecht een persoon zijn aan wie de aandelen vrij kunnen worden overgedragen en in de vestigingsakte is bepaald dat hem het stemrecht verbonden aan de verpande aandelen toekomt. In

401 Zo ook G.M. ter Huume, diss. p. 207. Naar mijn mening dient hier een kanttekening te worden gemaakt. De vestiging van een stil pandrecht lijkt mij rechtens zonder gevolg te blijven wanneer de statuten van de vennootschap het vestigen van een pandrecht op aandelen in haar kapitaal verbieden. 
dit geval zal de pandhouder na omzetting van het stille pand in een openbaar pand het stemrecht in de algemene vergadering kunnen uitoefenen.

In de tweede plaats kan de houder van het stille pand een persoon zijn aan wie de aandelen niet vrij kunnen worden overgedragen. De zaken liggen nu gecompliceerder. De wet bepaalt immers:

"Indien de pandhouder een persoon is aan wie de aandelen niet vrijelijk kunnen worden overgedragen, komt hem het stemrecht uitsluitend toe, indien dit bij de vestiging van het pandrecht is bepaald, en de bepaling is goedgekeurd door het vennootschapsorgaan dat bij de statuten is aangewezen om goedkeuring te verlenen tot een voorgenomen overdracht van aandelen, dan wel (...) door de algemene vergadering van aandeelhouders."

De schuldeiser kan in dit geval weliswaar met de aandeelhouder overeenkomen dat de laatste zijn aandelen stil aan hem verpand en tevens in de vestigingsakte bepalen dat de houder van het stille pandrecht gerechtigd zal zijn tot het stemrecht verbonden aan de betreffende aandelen, echter het vennootschapsorgaan dat statutair aangewezen is goedkeuring te verlenen tot een voorgenomen aandelenoverdracht respectievelijk de algemene vergadering van aandeelhouders zal deze bepaling dienen goed te keuren alvorens het stemrecht feitelijk door de pandhouder kan worden uitgeoefend. Het is mijns inziens deze laatste restrictie die een halt toe roept aan het daadwerkelijk kunnen uitoefenen van het stemrecht door de pandhouder op het moment waarop het stille pandrecht wordt omgezet in een gewoon pandrecht. Verleent het daartoe aangewezen vennootschapsorgaan geen goedkeuring aan de overgang van het stemrecht dan blijft de pandhouder hiervan verstoken.

In het derde geval liggen de kaarten weer een stuk eenvoudiger. De laatste volzin van het derde lid van art. $89 \mathrm{BW}$ bepaalt dat de statuten van de vennootschap, ten aanzien van de overgang van het stemrecht van de aandeelhouder naar de pandhouder, een geheel eigen regeling kunnen inhouden. Een regeling die volledig afwijkt van het bepaalde in de eerste drie volzinnen van het genoemde lid. De statuten van de open naamloze vennootschap kunnen dus bijvoorbeeld een regeling toestaan waarbij wordt bepaald dat het stemrecht niet op het moment van vestiging van het stille pandrecht overgaat maar eerst op het moment van het openbaar worden van het pandrecht.

De vormgevers van de statuten bij de open naamloze vennootschap zijn dus vrij in het creëren van een regeling betreffende het stemrecht bij stille verpanding van aandelen op naam.

Niet eens ben ik het met Ter Huurne wanneer zij schrijft:

"dat het niet in het systeem van de nieuwe regeling van de levering van aandelen op naam past dat een pandnemer door de enkele mededeling van het pandrecht aan de vennootschap 
(art. 3:239 lid 3 BW) kan bewerkstelligen dat hij stemrecht heeft. Dat is in strijd met de formaliteiten die in art. 2:196a (86a) BW voorschrijft bij een 'gewoon' pandrecht." ${ }^{402}$

Naar mijn mening biedt de wetgever namelijk zelf de mogelijkheid om bij een al dan niet beursgenoteerde - naamloze vennootschap een statutaire regeling te ontwerpen ten gevolge waarvan het stemrecht direct na het openbaar worden van het stille pandrecht overgaat van de aandeelhouder/pandgever naar de pandhouder. Ten aanzien van de intern-besloten vennootschap en de gemengde vennootschap deel ik opvatting van Ter Huurne.

\section{b. De intern-besloten vennootschap}

Voor wat de intern-besloten vennootschap betreft dient mijns inziens een andere redenering te worden gevolgd. Bij dit type vennootschap staat, zoals reeds eerder werd aangegeven, de beslotenheid van het samenwerkingsverband centraal. De wettelijke regeling met betrekking tot het uitoefenen van het stemrecht verbonden aan de verpande aandelen is dan ook een andere dan bij de onder a. beschreven naamloze vennootschappen. Volgens art. 198 lid 2 BW blijft het stemrecht op verpande aandelen in beginsel bij de aandeelhouder/pandgever berusten. Van dit beginsel kan echter worden afgeweken. Is de pandhouder een persoon aan wie de aandelen vrijelijk kunnen worden overgedragen en is de overgang van het stemrecht van aandeelhouder naar pandhouder bij de vestiging van het pandrecht bepaald, dan is de pandhouder gerechtigd in de algemene vergadering het stemrecht op de verpande aandelen uit te oefenen.

Bij een intern-besloten vennootschap zal evenwel de vrije kring van art. 195 lid 1 BW veelal zijn uitgesloten. Alsdan dienen we de tweede volzin van art. 198 lid 3 BW te volgen. Hier beginnen de verschillen ten opzichte van de NV-regeling.

\footnotetext{
"Indien de pandhouder niet zulk een persoon is, komt hem het stemrecht uitsluitend toe indien dit bij de vestiging van het pandrecht is bepaald en de vestiging van het pandrecht is goedgekeurd door het vennootschapsorgaan dat bij de stawten is aangewezen om goedkeuring te verlenen tot een voorgenomen overdracht van aandelen dan wel (...) door de algemene vergadering van aandeelhouders."
}

De vestiging van een stil pandrecht met overgang van het stemrecht van aandeelhouder naar pandhouder lijkt mij niet mogelijk onder deze omstandigheden. Met het eerste wettelijke vereiste zullen partijen nog wel kunnen leven. In de pandakte kan immers worden bepaald dat de pandhouder gerechtigd is tot het stemrecht verbonden aan de aandelen. Het tweede vereiste werpt evenwel roet in het eten. Ten gevolge van de goedkeuringseis wordt het pandrecht namelijk bekend bij de vennootschap. Het pandrecht behoudt zijn stille karakter in die zin dat het niet

402 G.M. ter Huume, diss. p. 206. 
'openbaar' wordt door erkenning danwel betekening maar de idee achter het stille pandrecht gaat mijns inziens teniet. De vestiging van een stil pandrecht zonder overgang van stemrecht kan naar mijn mening te allen tijde plaatsvinden, tenzij de mogelijkheid van verpanding van aandelen statutair is uitgesloten, door het achterwege laten van de betekening aan danwel erkenning door de vennootschap. Op het moment waarop het stille pandrecht zijn stille karakter verliest verkrijgt de pandhouder echter niet het stemrecht, ook al is dit in de vestigingsakte bepaald. Ik acht het echter wel verdedigbaar dat, indien het door de statuten aangewezen goedkeurende orgaan respectievelijk de algemene vergadering van aandeelhouders achteraf goedkeuring verleend aan de vestiging van het pandrecht met overgang van het stemrecht, de pandhouder alsnog het stemrecht kan verkrijgen. In een werkelijk besloten vennootschap acht ik deze gang van zaken niet opportuun. De algemene vergadering zal immers onder deze omstandigheden geen goedkeuring verlenen aan de vestiging van een pandrecht met overgang van stemrecht. In een werkelijk besloten samenwerkingsverband zal mijns inziens dan ook altijd gebruik worden gemaakt van de laatste volzin van het derde lid van art. 198 BW. De statuten van zo'n samenwerkingsverband zullen de bevoegdheid tot toekenning van het stemrecht aan de pandhouder uitsluiten.

\section{c. De gemengde vennootschap}

Hetgeen hiervoor onder a. en b. werd opgemerkt komt tezamen indien we spreken over de stille verpanding van aandelen op naam in een gemengde vennootschap.

In § II.7.4 beschreef ik de gemengde vennootschap als een open naamloze vennootschap met een besloten kern. De gemengde vennootschap kan een beursnoterende vennootschap zijn. Naast aandelen aan toonder zal deze vennootschap gewone aandelen op naam hebben uitgegeven alsmede bijzondere aandelen op naam, waarbij gedacht kan worden aan preferente beschermingsaandelen en prioriteitsaandelen. Ook komt het voor dat zo'n vennootschap een pakket naamaandelen ter certificering bij een administratiekantoor heeft geplaatst. Ten aanzien van de stille verpanding van gewone aandelen op naam zou ik willen verwijzen naar hetgeen hieromtrent werd opgemerkt ten aanzien van de stille verpanding bij de naamloze vennootschappen. Voor de stille verpanding van bijzondere naamaandelen, de zogenaamde machtsaandelen, geldt hetgeen beschreven is bij de intern-besloten vennootschap.

Aan het einde van deze paragraaf een opmerking over de twee systemen die te onderscheiden zijn ten aanzien van de verpanding van aandelen op naam in gewone naamloze vennootschappen en besloten samenwerkingsverbanden enerzijds en verpanding van aandelen in beursgenoteerde samenwerkingsverban- 
den anderzijds. Met Ter Huurne ${ }^{403}$ ben ik van mening dat het bestaan van twee wettelijke regimes bijzonder ongelukkig is en tot verwarring aanleiding kan geven. Ik zou er dan ook voor willen pleiten de regeling van de - stille - verpanding bij al dan niet beursgenoteerde naamloze vennootschappen en besloten vennootschappen gelijk te trekken, en wel in die zin dat de wetgever expliciet bepaald dat stille verpanding van aandelen die op naam luiden ook bij de besloten samenwerkingsverbanden en de gewone naamloze vennootschap mogelijk moet zijn en dat het vestigen van een stil pandrecht te allen tijde bij notariële akte dient te geschieden.

II.7.6 Wettelijke bescherming van de beslotenheid in geval van verpanding van aandelen

In de voorafgaande paragrafen werd beschreven op welke wijze de beslotenheid van het samenwerkingsverband van binnen uit, door middel van statutaire bepalingen, kan worden beschermd. In deze paragraaf zal aandacht worden besteed aan de externe bescherming van de beslotenheid, de bepalingen die de wetgever expliciet heeft opgenomen. Op een drietal plaatsten vindt men die bepalingen, te weten in art. 89 lid $5 \mathrm{BW}$, in art. 198 lid $5 \mathrm{BW}$ en in het vierde lid van art. 474g Rv.

De strekking van art. $474 \mathrm{~g}$ lid $4 \mathrm{Rv}$ is gelegen in het waarborgen van het besloten karakter van de vennootschap. In geval van executie van een beslag rustend op de aandelen zal de deurwaarder gehouden zijn de rechten en verplichtingen ten aanzien van de vervreemding van aandelen die wet en statuten hem opleggen na te leven. Dit betekent dat de executerende deurwaarder de regels van de blokkering van aandelen in acht moet nemen. Indien de statutaire blokkade de executie van de aandelen onmogelijk maakt, kan de rechtbank van deze bepalingen afwijken.

Betreffende de leden 5 van de artt. 89 en 198 BW geldt een gelijke redenering. De executerende pandhouder is gehouden de wettelijke en statutaire regels betreffende de vervreemding en overdracht van aandelen na te leven. Houden de statuten een aanbiedingsblokkade in dan zal de pandhouder de aandelen eerst aan de aandeelhouders dienen aan te bieden, is er een goedkeuringsblokkade, dient goedkeuring te worden verkregen voor de verkoop. De bescherming die door de genoemde artikelen wordt geboden is relatief. Gaat het om een groot pakket aandelen dan zal het voor degenen die het recht hebben op de aangeboden aandelen te reflecteren veelal moeilijk zijn financiën bijeen te garen teneinde het pakket over te nemen. Voor de goedkeuring geldt in principe hetzelfde. Bij weigering van de goedkeuring, dient een andere gegadigde te worden aangewezen die bereid is het pakket te kopen. Deze gegadigde zal zich voor het zelfde

403 G.M. ter Huume, diss. p. 208. 
probleem gesteld zien. In deze gevallen zal ondanks alle mogelijk beschermingspogingen de beslotenheid van de vennootschap worden doorbroken. 


\section{Pandrecht op aandelen en de juridische fusie}

\section{II.8 De positie van de pandhouder in geval van een juridische fusie}

\section{II.8.1 Inleiding}

In titel 7 van Boek $2 \mathrm{BW}$ wordt de juridische fusie geregeld. ${ }^{404}$ Deze wordt omschreven als een rechtshandeling van twee of meer rechtspersonen waarbij een van deze het vermogen van de andere onder algemene titel verkrijgt of waarbij een nieuwe rechtspersoon die bij deze rechtshandeling door hen samen wordt opgericht, hun vermogen onder algemene titel verkrijgt. ${ }^{405}$ Deze fusievorm staat slechts open voor rechtspersonen die dezelfde rechtsvorm hebben. ${ }^{406}$ In deze paragraaf zal aandacht worden besteed aan de fusie tussen twee vennootschappen met een besloten karakter, waarbij de ene optreedt als verkrijgende vennootschap van het vermogen van de verdwijnende vennootschap. Ten gevolge van deze rechtshandeling verdwijnen de aandelen in de verdwijnende vennootschap en hiervoor treden van rechtswege (onder omstandigheden krachtens een bepaalde ruilverhouding) aandelen in de verkrijgende vennootschap in de plaats.

Wanneer nu een besloten vennootschap juridisch fuseert met een andere vennootschap, waarvan (een aantal van) de aandelen (is) zijn verpand, doen zich interessante vragen voor. Verkrijgt de pandhouder van aandelen in de verdwijnende vennootschap een pandrecht op hetgeen daarvoor in de plaats komt? Anders gezegd, verkrijgt de pandhouder een pandrecht op de aandelen in de verkrijgende vennootschap? Luidt het antwoord op deze vraag anders indien in de statuten van de verkrijgende vennootschap een verbod tot verpanding van aandelen is opgenomen? Wat is rechtens indien de houder van een pandrecht op de aandelen in de verdwijnende vennootschap gerechtigd is het stemrecht op deze aandelen uit te oefenen en de statuten van de verkrijgende vennootschap een dergelijke stemrechtovergang uitsluiten?

404 De juridische fusie zoals deze in de Boek $2 \mathrm{BW}$ is opgenomen is gebaseerd op de Derde richtlijn van de Raad van de EG op het terrein van het vennootschapsrecht van 9 oktober 1978. betreffende de juridische fusie van naamloze vennootschappen.

405 Art. 309 BW.

406 Art. 310 lid $1 \mathrm{BW}$. 


\section{II.8.2 Bescherming van de pandhouder in geval van een juridische fusie}

In het tweede lid van art. $311 \mathrm{BW}$ lezen wij dat de aandeelhouders van de verdwijnende rechtspersoon door fusie aandeelhouder worden van de verkrijgende rechtspersoon. Op deze hoofdregel wordt een aantal uitzonderingen gemaakt. Deze uitzonderingen zijn neergelegd in de artt. 310 lid 4, 333 en 334 BW. ${ }^{407}$ Voorts kan het voorkomen dat de aandeelhouder in de verdwijnende vennootschap, krachtens de ruilverhouding van de aandelen, geen recht kan doen gelden op de aandelen in de verkrijgende vennootschap. ${ }^{408}$ In dit laatste geval zal, met inachtneming van het bepaalde in art. 325 BW, een uitkering in geld plaatsvinden. De rechtspositie van de aandeelhouder in de verdwijnende vennootschap is dus gewaarborgd.

Hoe nu te oordelen over de positie van de houder van een pandrecht op de aandelen in de verdwijnende vennootschap. Wordt zijn positie eveneens beschermd?

Art. $319 \mathrm{BW}$ is in deze erg duidelijk. Een pandrecht dat rust op aandelen in de verdwijnende vennootschap gaat over op hetgeen daarvoor in de plaats treedt. Wanneer het pandrecht op een aandeel rust waarvoor niets in de plaats komt dan moet de verkrijgende vennootschap een gelijkwaardige vervanging (geld) geven. $\mathrm{Er}$ is hier dus eveneens sprake van een zaaksvervanging van rechtswege. ${ }^{409}$

\section{II.8.3 Zaaksvervanging ondanks verbod van verpanding?}

Eerder ${ }^{410}$ zagen wij dat in de statuten van besloten en naamloze vennootschappen verpanding van aandelen op naam uitgesloten kan worden. De statuten kunnen een verbod van verpanding inhouden. Stel nu dat de statuten van de verkrijgende vennootschap zulk een verbod kennen en dat op de aandelen in de verdwijnende vennootschap een pandrecht rust. Kan er nu toch sprake zijn van zaaksvervanging of komt het pandrecht te vervallen?

407 De regel van art. 311 lid 2 vindt geen doorgang wanneer de verkrijgende rechtspersoon enige aandeelhouder is van de verdwijnende vennootschap (art. 310 lid 4); wanneer iemand alle aandelen houdt in het kapitaal van de te fuseren vennootschappen en de verkrijgende vennootschap geen aandelen toekent (art. 333); wanneer is overeengekomen dat de aandeelhouders van een verdwijnende vennootschap aandeelhouders worden van een groepsmaatschappij van de verknigende vennootschap (art. 334).

408 Art. 325 BW.

409 De bepaling van art. $319 \mathrm{BW}$ vindt zijn grondslag niet in de Derde richtlijn. $\mathrm{Zij}$ is afgestemd op art. 3:229 lid I BW: "Het recht van pand (...) brengt van rechtswege mee een recht van pand op alle vorderingen die in de plaats van het verbonden goed treden, waaronder begrepen vorderingen terzake van waardevermindering van het goed." aldus ar. 3:229 lid 1 BW. Zie ook P.J. Dortmond, De juridische fusie naar wordend recht, preadvies 1980, p. 55 e.v.

410 Zie $\$ 1.3$. 
In het Handboek ${ }^{411}$ lezen we dat een statutaire bepaling waarin de mogelijkheid van verpanding van aandelen wordt uitgesloten niet geldt voor het pandrecht dat van rechtswege op aandelen in de verkrijgende vennootschap wordt verkregen. Deze stellingname wordt niet nader gemotiveerd. In de $\mathrm{MvT}^{412}$ op art. $319 \mathrm{BW}$ lezen we:

\begin{abstract}
"Op de aandelen of certificaten daarvan in de verdwijnende vennootschappen die worden omgewisseld tegen aandelen in de verkrijgende vennootschap, kan een pandrecht of een recht van vruchtgebruik rusten. De pandhouder en de vruchtgebruiker moeten van de fusie geen nadeel ondervinden."
\end{abstract}

De juridische fusie mag dus geen nadelige gevolgen hebben voor de rechtspositie van de houder van een pandrecht op aandelen in de verdwijnende vennootschap. Indien een verbod van verpanding opgenomen in de statuten van de verkrijgende vennootschap zou betekenen dat de zaaksvervanging van rechtswege geen doorgang zou vinden, dan zou de regel van art. 319 BW wel erg weinig om het lijf hebben. ${ }^{413}$ De positie van de pandhouder wordt in deze dus ook beschermd.

\title{
II.8.4 Pandhouder met stemrecht. Ook op de nieuwe aandelen?
}

De statuten van de vennootschap kunnen de mogelijkheid bieden dat het stemrecht verbonden aan de verpande aandelen niet door de aandeelhouder maar door de pandhouder wordt uitgeoefend. ${ }^{414}$

Stel nu dat de statuten van de verdwijnende vennootschap zulk een bepaling kennen, maar dat de statuten van de verkrijgende vennootschap een dergelijke stemrechtovergang uitsluiten. De vraag die dan rijst is of het stemrecht, dat de positie van de pandhouder in zekere mate versterkt, ten gevolge van de juridische fusie teloor gaat. Een aantal gevallen is denkbaar. Wanneer de statuten van de verkrijgende vennootschap de stemrechtovergang van de aandeelhouder naar de pandhouder onverkort toestaan, ben ik van mening dat de pandhouder die, krachtens art. $319 \mathrm{BW}$, een pandrecht verkrijgt op de aandelen in deze vennootschap het stemrecht op deze aandelen mag uitoefenen, wanneer dit recht hem ook toekwam ten aanzien van de aandelen die ten gevolge van de fusie verdwenen. Ik

411 Handboek (1992), nr. 416.

412 J.M.M. Maeijer, Wetsgeschiedenis, IXp - art. 319 - I.

413 Zie in gelijke zin P.J. Dortmond, Preadvies 1980, p. 80 en Enige beschouwingen rondom aandelen, diss. p. 102. Schrijver merkt op: "Zou men de vrijheid hebben het pandrecht op de te verkrijgen aandelen uit te sluiten, dan is de kracht van artikel 319 wel zeer uitgehold. Ik zie dan ook in artikel 319 een voorschrift voor zaaksvervanging, dat sterker is dan de door de wet gegeven bevoegdheid in de statuten het pandrecht op aandelen te verbieden."

414 Hoofdregel in deze is dat het stemrecht verbonden aan de verpande aandelen toekomt aan de pandgever/aandeelhouder (ar. 198 lid 2). Echter, de statuten van de vennootschap kunnen van deze regel afwijken op de wijze beschreven in art. 198 lid 3. 
acht de bevoegdheid tot het uitoefenen van het stemrecht als zodanig verbonden aan het gevestigde pandrecht op de aandelen. ${ }^{415}$ Opgemerkt dient te worden dat in het hier beschreven geval het steeds zal gaan om een verkrijgende naamloze vennootschap. Slechts voor deze rechtsvorm staat de wet, in de laatste volzin van het derde lid van art. $89 \mathrm{BW}$, toe dat een dergelijke regeling ten aanzien van de overgang van het stemrecht in de statuten wordt opgenomen. Wanneer de verkrijgende rechtspersoon een besloten vennootschap ${ }^{416}$ is, zullen de statuten een andere regeling dienen te bevatten.

De overgang van het stemrecht zal, indien de pandhouder niet een persoon is aan wie de aandelen vrijelijk kunnen worden overgedragen, onderworpen moeten worden aan een goedkeuring als bedoeld in art. 198 lid 3 BW. ${ }^{417}$

De vraag die zich dan aandient is of, in het geval van een juridische fusie, het bevoegde orgaan haar goedkeuring moet verlenen aan de overgang van het stemrecht van de aandeelhouder naar de pandhouder of dat zulks van rechtswege geschiedt. Bij de beantwoording van deze vraag ben ik geneigd de visie van Dortmond te volgen. Schrijver is, onder verwijzing naar de ratio van de wettelijke stemrechtregeling, van mening dat een dergelijke goedkeuring niet hoeft plaats te vinden. Hij ${ }^{418}$ schrijft:

\begin{abstract}
${ }^{\text {n}}$ De ratio van de wettelijke bepaling op grond waarvan het stemrecht niet zonder meer kan toekomen an een pandhouder $(.$.$) is immers te voorkomen, dat, indien de aandelen zijn$ geblokkeerd, het besloten karakter der vennootschap zou worden aangetast, wanneer aandeelhoudersrechten vrijelijk op bedoelde zakelijke gerechtigden zouden mogen overgaan. Waar door het fusiebesluit het besloten karakter van de vennootschap met een blokkeringsregeling, wordt opengebroken, in zoverre dat de verkrijgende vennootschap, haar poorten open stelt voor de aandeelhouders van de vennootschap die zij door fusie overneemt (...), wordt de in de statuten tot uitdrukking komende blokkeringsgedachte van de verkrijgende vennootschap bij fusie tijdelijk 'buiten werking gesteld'. Indien nu bij fusie een uizzondering wordt gemaakt op de beslotenheid, op welk beginsel de blokkeringsregeling is gebaseerd, dan dient de uitzondering ook te gelden voor de op de blokkeringsregeling berustende beperking van het toekennen van het stemrecht aan pandhouders (...), wier recht door de fusie overgaat als waren zij personen, aan wie de aandelen vrijelijk kunnen worden overgedragen."
\end{abstract}

In het geval waarin de statuten van de verkrijgende vennootschap de mogelijkheid van overgang van het stemrecht uitsluiten c.q. verbieden dient men tot een andere conclusie te komen. Als de statuten zulk een verbod kennen zou ik, tegen de achtergrond van het besloten karakter van de vennootschap, het intuitu personae aangegane samenwerkingsverband, willen aannemen dat dit verbod dient te

415 Zie ook P.J. Dortmond, diss. p. 106.

416 of een (intern-besloten of gemengde) naamloze vennootschap die een regeling in haar statuten heeft opgenomen conform art. 89 lid 3, tweede volzin.

417 Zie voor deze problematiek $\$$ I.6.

418 P.J. Dortmond, diss. p. 106-107. 
worden gerespecteerd. ${ }^{419}$ Het stemrecht komt dan na de juridische fusie toe aan de pandgever/aandeelhouder en niet langer aan de pandhouder.

Dortmond merkt in deze nog op dat:

"De stemgerechtigde pandhouder van de aandelen in de oude vennootschap die zijn stemrecht verloren ziet gaan, heeft als enige middel om dit te voorkomen de mogelijkheid in de algemene vergadering waarin tot fusie wordt besloten, tegen de fusie te stemmen. ${ }^{\text {na20 }}$

Wanneer de zakelijk gerechtigde een aanzienlijk pakket aandelen in de besloten vennootschap in pand houdt is de mogelijkheid dat hij de fusie, door tegen het fusie voorstel te stemmen, kan verijdelen geenszins denkbeeldig te achten.

419 Handboek (1992), nr. 416. Zie ook P.J. Dortmond, diss. p. 107.

420 P.J. Dortmond, diss. p. 107. 



\section{Pandrecht op aandelen en de uitkoop- en geschillenregeling}

\section{II.9 Inleiding}

In dit hoofdstuk zal worden ingegaan op de positie van de houder van een pandrecht op aandelen, indien deze wordt geconfronteerd met een vordering op basis van de uitkoopregeling van art. 92a/201a BW danwel wordt betrokken in een geschillenprocedure. Bij deze bespreking zal eerst de uitkoopregeling worden bezien. Hiertoe zal, in beperkte zin, aandacht worden besteed aan de regeling als zodanig. Vervolgens zal een drietal relaties worden geanalyseerd, te weten de relatie tussen de uitkoper en de aandeelhouder/pandgever, de betrekking tussen de uitkoper en de pandhouder en de verhouding tussen de pandgever en de pandhouder. In het tweede gedeelte van dit hoofdstuk zal de geschillenregeling aan bod komen. Hierbij zal met name aandacht worden besteed aan de positie van de pandhouder in die gevallen waarin hij enerzijds wordt geconfronteerd met een vordering tot overdracht ingesteld tegen de aandeelhouder/pandgever, anderzijds met een aandeelhouder/pandgever die zelf een vordering tot overname van de verpande aandelen instelt. Ten slotte zal de positie van de pandhouder worden besproken wanneer jegens hem een vordering tot overdracht van het stemrecht wordt ingesteld. 



\section{II.10 De uitkoopregeling}

Het eerste lid onder e van art. 6 van de Fusiegedragsregels bepaalt dat, indien een naamloze vennootschap een openbaar bod uitbrengt op de, ter beurze of op de parallelmarkt genoteerde, aandelen in een andere naamloze vennootschap, aan alle houders van de zelfde soort aandelen hetzelfde bod moet worden gedaan. Ondanks deze regel is het uiteraard mogelijk dat bij een 'geslaagd' openbaar bod op aandelen, in een ter beurze genoteerde naamloze vennootschap, niet alle aandelen door de bieder worden verkregen. Hieraan kunnen verschillende oorzaken ten grondslag liggen. Aandeelhouders zijn niet verplicht op een bod in te gaan of het bod heeft hen niet bereikt; aandeelbewijzen kunnen zoekgeraakt zijn; de aandelen kunnen zich bevinden in een onverdeelde boedel waarin de deelgerechtigden onvindbaar zijn. Bovendien is het goed denkbaar dat de aandeelhouder, die weet heeft van zijn 'bedreigende positie' voor de vennootschap, tracht te bereiken alsnog tegen een hoger bod te worden uitgekocht. ${ }^{421}$

Ten aanzien van dit laatste dient evenwel te worden opgemerkt dat art. 12 van de Fusiegedragsregels ${ }^{422}$ bepaalt dat, wanneer de overnemende NV haar bod gestand heeft gedaan, het haar gedurende een periode van drie jaar na de publikatie van het biedingsbericht danwel de annonce niet is toegestaan aandelen van de soort waarop het bod betrekking had, direct of indirect, te verwerven tegen voor de houder van die aandelen gunstiger voorwaarden dan volgens het openbare bod. ${ }^{423}$ Eveneens kan een emotionele of traditionele band tussen aandeelhouder en vennootschap in de weg staan aan een overdracht van aandelen na een openbaar bod. ${ }^{424}$

421 De waarde die aan die bedreiging wordt toegekend wordt in de literatuur aangeduid met de term nuisance-value; zie ook Handboek (1992), $\mathrm{nr} 199 ;$; . van Schilfgaarde, Van de BV en de NV, $10^{\circ}$ druk, nr. 130; S.M. van Steenbergen, De mogelijkheid van uitkoop van kleine minderheidsbelangen in NV's en BV's, TVVS 1988, p. 143.

422 SER-Besluit Fusiegedragsregels 1975.

423 In de tweede volzin van art. 12 Fusiegedragsregels wordt evenwel in de aanhef en onder het tweede gedachtenstreepje bepaald dat het verbod niet geldt voor verwervingen in regelmatig beursverkeer dan wel ingevolge de vorderingen bedoeld in ant. 92a en an. 201a Boek 2 BW. Mijn inziens ziet deze bepaling op de volgende situatie. Een NV verkrijgt na een bod $95 \%$ van de aandelen in een andere vennootschap. Op grond van de ant. $92 \mathrm{a} / 201 \mathrm{a}$ is de NV gerechtigd de overige $5 \%$ uit te kopen. De NV kan nu een hoger bod gestand doen dan dat ten gevolge waarvan zij de $95 \%$ verkreeg. Zie ook C.A. Schwarz, E.J.R. Loos, Artikel 12 van de SERFusiecode, mede in het licht van de opvolging van een openbaar bod door een juridische fusie of geschillenprocedure, verschenen in NJB mei 1996.

424 S.M. van Steenbergen, TVVS 1988, p. 143. 
Ook bij een overname van een besloten vennootschap kan het probleem van een overblijvende minderheidsaandeelhouder zich voordocz ${ }^{425}$

Indien de overnemer c.q. bieder, bij een openbaar bod, met één of meer van de bovengenoemde omstandigheden geconfronteerd wordt, dan blijft hij zitten met een of meer minderheidsaandeelhouders. Dit kan uiterst onaangename consequenties met zich brengen. ${ }^{426}$

425 Vgl. HR 17 mei 1991, NJ 1991, 645 (Lampe/Tonnema) nt. Maeijer. Zie ook over dit arrest M.J.G.C. Raaijmakers, Besluit van aandeelhouders tot statutenwijziging in strijd met de redelijkheid en billijkheid, AAe 40 (1991), p. 1009 e.v.

426 In de Memorie van Toelichting (TK $18904, \mathrm{nr} .3$ ) lezen we dat het klein aantal aandeelhouders dat het bod niet heeft aanvaard in ruwweg vier groepen onderscheiden wordt. In de eerste plaats zijn er de aandeelhouders die hopen door de overlast die hun aanwezigheid veroorzaakt, na verloop van tijd hun aandelen tegen een hogere prijs alsnog aan de groot-aandeelhouder (moedervennootschap) te verkopen (nuisance-value). In de tweede plaats zijn er de aandeelhouders die, uit overwegingen van traditie of verbondenheid met de vennootschap, geen afstand kunnen doen van hun deelneming. De dende groep wordt gevormd door de houders van aandelen die verzuimd hebben op het bod in te gaan. De vierde groep tenslotte bestaat uit zoekgeraakte aandeelhouders. De drie laatste groepen zullen in het algemeen geen pogingen ondernemen om de groot-aandeelhouder (moedervennootschap) tot last te zijn. Evenwel brengt enkel hun aanwezigheid reeds aanzienlijke bezwaren met zich mee voor de groot-aandeelhouder. Immers iedere aandeelhouder heeft rechten die door de vennootschap gerespecteerd dienen te worden. De bezwaren kunnen zowel fiscaalrechtelijk als civielrechtelijk van aard zijn. Indien de 'outside-aandeelhouders' tezamen een belang van meer dan $1 \%$ vertegenwoordigen is het onmogelijk een fiscale eenheid uussen moeder- en dochtervennootschap te vormen (zie ar. $15 \mathrm{Wet} \mathrm{Vpb}$ ). Immers, eén van de wettelijke vereisten voor het vormen van een fiscale eenheid is dat de moedervennootschap tenminste $99 \%$ van de aandelen in de dochtervennootschap bezit. De groot-aandeelhouder (moedervennootschap) loopt op deze wijze enkele fiscaalrechtelijke voordelen mis. Zo vindt er in de eerste plaats geen horizontale verliescompensatie plaats tussen de concernmaatschappijen. Voorts blijven kostenverrekeningen tussen concemmaatschappijen fiscaal relevant en op intervennootschappelijke transacties vindt winstbestemming plaats, zodat over interne reorganisaties vennootschapsbelasting wordt geheven (zie W.J. Slagter, Compendium, 6 de druk, $\$ 142$. ) Civielrechtelijk valt te wijzen op enkele bepalingen uit het jaarrekeningenrecht. De minderheidsaandeelhouders kunnen het opmaken van een geconsolideerde jaarrekening verhinderen (art. 403 lid 1 sub b BW). Voorts dienen alle formele eisen omtrent het bijeenroepen en het houden van algemene vergaderingen in acht te worden genomen (artt. 222-226 BW). Ten aanzien van de dividendpolitiek van de vennootschap kan het volgende worden opgemerkt. Indien de grootaandeelhouder (moedervennootschap) geen dividend wil ontvangen (wegens voorgenomen investeringen), kan een uitkering aan de minderheidsaandeelhouders niettemin redelijk zijn. Echter het doen van een uitkering aan de minderheidsaandeelhouders brengt met zich mee dat ook aan de moeder dividend moet worden uitgekeend. Tevens dient de dochter, gelet op de belangen van de minderheidsaandeelhouders, op de voet van een buitenstaander te worden behandeld bij het sluiten van overeenkomsten (zie $P$. van Schilfgaarde, Van de BV en de NV, $10^{\mathrm{c}}$ druk, nr. 130. Zie ook P.C. van den Hoek, De uitkoopregeling van aandelen, Dossier Account, 1990/91, p. 43: "(...) op het gebied van transacties die hij (de 95\%-aandeelhouder; $\Pi$ ) met de vennootschap in kwestie sluit; deze zullen tegen objectief verdedigbare condities (at arms length) moeten plaatsvinden.") Tevens kan gewezen worden op art. 333 BW, welk artikel een vereenvoudigde regeling geeft voor juridische fusie ten aanzien van $100 \%$ deelnemingen (zie o.a. 
Teneinde aan de problematiek van de resterende aandeelhouders een einde te maken werd op 15 maart 1985 het wetsvoorstel 18904 ter "invoering van de mogelijkheid van uitkoop van kleine minderheidsbelangen in naamloze en besloten vennootschappen" bij de Tweede Kamer ingediend. Dit voorstel van wet, waarbij twee nieuwe artikelen in Boek 2 BW zijn ingevoegd - de artt. 92a en $201 \mathrm{a}-$, is op 1 mei 1988 in werking getreden. ${ }^{427}$

Lid 1 van de artt. 92a en 201a BW bepaalt dat degene die als aandeelhouder ${ }^{428}$ voor eigen rekening ten minste $95 \%{ }^{429}$ van het geplaatste kapitaal van de vennootschap verschaft, tegen de gezamenlijke andere aandeelhouders een vordering kan instellen tot overdracht van hun aandelen aan de eiser. Het percentage wordt berekend over de aandelen, die niet worden gehouden door de vennootschap zelf of door haar dochtermaatschappijen. ${ }^{430}$ Hetzelfde geldt indien twee of meer groepsmaatschappijen dit deel van het geplaatste kapitaal samen verschaffen en samen de vordering instellen tot overdracht aan één van hen. ${ }^{431}$

Het recht tot uitkoop kan slechts tegen de 'gezamenlijke andere aandeelhouders' worden uitgeoefend. Selectieve uitkoop is dus niet toegestaan.

De vordering - tegen alle andere aandeelhouders - tot uitkoop dient aanhangig te worden gemaakt bij de Ondernemingskamer van het Gerechtshof te Amsterdam. Van de uitspraak staat uitsluitend beroep in cassatie open.

Het moge duidelijk zijn dat de bevoegdheid tot uitkoop erg diep grijpt in het eigendomsrecht van gedaagden. Onomstotelijk zal daarom moeten vaststaan dat de uitkoper bevoegd is zijn - hier te bespreken - recht uit te oefenen.

$426 \rightarrow$

TK 18 904, nr. 3; W. Westbroek, WPNR 5759 (1985). p. 709/710; S.M. van Steenbergen, TVVS 1988, p. 143/144; W.J. Slagter, Wetsontwerp betreffende uitkoop van minderheidsaandeelhouders, TVVS 1985 , p. 128; L.G.H.J. Houwen, De wettelijke regeling tot uitkoop van minderheidsaandeelhouders, NV 66 (1988). p. 17 e.v.

427 Staatsblad 1988, ar. 85 (Wet van 3 maart 1988 tot invoering van de mogelijkheid van uitkoop van kleine minderheidsbelangen in naamloze en besloten vennootschappen).

$428 \mathrm{Zie}$ voor de mogelijkheid dat een Administratie kantoor een vordering tot uitkoop kan instellen; R. van der Vist, Uitkoop van kleine minderheidsbelangen in NV's en BV's, NV 63 (1985), pp. 162/163. Anders: F.J.P. van den Ingh, diss. p. 217/218.

429 Omtrent de hoogte van het percentage heeft discussie plaatsgevonden, zie M.J. van Vliet, NV 69 (1991), p. 31, L.G.H.J. Houwen, NV 66 (1988), p. 23, S.M. van Steenbergen, TVVS 1988, p. 145, R. van der Vist, NV 63 (1985), p. 163.

430 Aanvankelijk volgde dit uit lid 1 van art. 92a/201a BW. Thans volgt dit uit de arth. $24 d$ en 228 lid $6 \mathrm{BW}$.

431 Indien groepsmaatschappijen gezamenlijk het vereiste percentage houden, kunnen zij slechts gezamenlijk als eiser optreden. Wel moeten zij opgeven welke eiser alle aandelen zal ovememen. Immers, het is voor gedaagden van belang slechts én enkele tegenpartij te hebben die tot betaling van het vastgestelde bedrag zal overgaan. Zie MvT op an. 92a lid 1 (J.M.M. Maeijer, Wetsgeschiedenis, p. IXx - art. 92a - 2); zie ook S.M.van Steenbergen, TVVS 1988. p. 144. 
Indien tegen éen of meer gedaagden verstek is verleend, dient de uitkoper de rechter aan te tonen dat hij het voor het uitkooprecht vereist percentage aandelen werkelijk houdt, al dan niet samen met één of meer groepsmaatschappijen (zie lid 3). In lid 4 van genoemde artikelen wordt bepaald onder welke omstandigheden de rechter de vordering tot uitkoop tegen alle gedaagden dient af te wijzen. ${ }^{432}$ De rechter zal de vordering afwijzen indien een gedaagde, ondanks de vergoeding, ernstige stoffelijke schade zou lijden door de overdracht. Uit de Memorie van Toelichting blijkt dat slechts financieel nadeel grond voor verweer is en niet bijvoorbeeld de emotionele band die een kleine aandeelhouder met de vennootschap heeft. ${ }^{433}$ De rechter wijst de vordering eveneens af als de gedaagde houder is van een prioriteitsaandeel. Deze restrictie is begrijpelijk. Uitkoop is alleen gerechtvaardigd indien de zeggensmacht in de AVA zo goed als in één hand is. Echter, aan prioriteitsaandelen kunnen bijzondere zeggenschapsrechten verbonden zijn. De overwegingen die geleid hebben tot de uitgifte van deze aandelen dienen te worden gerespecteerd. De prioriteitsaandeelhouder kan niet gedwongen worden deze rechten tegen zijn wil op te geven. ${ }^{434}$ In de praktijk zal het veelal zo zijn dat de groot-aandeelhouder met de houder(s) van de prioriteitsaandelen overeenstemming tracht te bereiken ten aanzien van de overdracht van die aandelen aan de groot-aandeelhouder, danwel tot een wijziging van de statuten in die zin dat de prioriteitsaandelen worden ingetrokken. Men kan zich immers afvragen hoe groot de macht van de houders van prioriteitsaandelen nog is indien zij tegenover zich een $95 \%$-aandeelhouder zien. De wet bepaalt bijvoorbeeld dat statutair kan worden geregeld dat de benoeming van bestuurders zal geschieden uit een (bindende) voordracht. Het doen van deze bindende voordracht behoort veelal tot de bevoegdheden van de vergadering van prioriteitsaandeelhouders. Deze voordracht kan echter worden doorbroken, zo bepaalt de wet, bij een besluit genomen met twee derden van de uitgebrachte stemmen, vertegenwoordigende meer dan de helft van het kapitaal. Aan deze eisen zal de 95\%-aandeelhouder voldoen, zodat de macht van de prioriteitsaandeelhouder in de meeste gevallen doorbroken zal kunnen worden. Tenslotte wijst de rechter de vordering af wanneer de eiser jegens een gedaagde afstand heeft gedaan van zijn bevoegdheid de vordering tot uitkoop in te stellen. Aangenomen moet worden dat eiser zulk een afspraak slechts maakt, indien hij op zijn beurt wordt gevrijwaard voor hinderlijke gevolgen van dit aandeelhouderschap. ${ }^{435}$

432 Zie ook W.J. Slagter, Uitkoopregeling. TVVS 1990, p. 232; M.J. van Viet, NV 69 (1991), p. 35 .

433 TK 18904 , nrs. 3 , p. 8.

434 TK 18904 , nr. 5-7.

435 TK 18 904, nr. 3. 
Indien de rechter de vordering toewijst kan hij één of drie deskundigen benoemen die berichten over de waarde van de over te dragen aandelen. ${ }^{436}$

De rechter bepaalt de prijs die de over te dragen aandelen op een door hem te bepalen dag hebben. Die prijs zal veelal worden vastgesteld aan de hand van een balans, van tussentijdse cijfers of van een tussentijdse opneming. De rechter en de deskundigen zullen bij de prijsvaststelling uiteraard acht slaan op de waarde die de aandelen in het economisch verkeer vertegenwoordigen. Uit de rechterlijke uitspraak moet blijken per wanneer de prijs is bepaald. Van die dag af wordt de prijs verhoogd met de wettelijke rente. Dit dient de koper aan te sporen weldra tot koop over te gaan. Zoals de rente bij de prijs komt, komen uitkeringen na de peildatum in mindering op de feitelijke prijs. ${ }^{437}$

Indien de rechter de vordering tot overdracht toewijst, veroordeelt hij de overnemer aan degenen aan wie de aandelen toebehoren of zullen toebehoren, de vastgestelde prijs met rente te betalen tegen levering van het onbezwaarde recht (zonder pand, vruchtgebruik of beslag) op de aandelen.

De eiser dient de desbetreffende aandelen dus over te nemen tegen betaling van de door de rechter vastgestelde prijs. De gedaagden dienen de aandelen onbezwaard aan de eiser te leveren. De eiser deelt de dag en de plaats van betaalbaarstelling en de prijs van de over te nemen aandelen schriftelijk mee aan de houders van de over te nemen aandelen van wie hij het adres kent. Kent hij niet van allen het adres, dan moet hij bovendien deze aankondiging doen in een landelijk verspreid dagblad.

De Memorie van Toelichting ${ }^{438}$ zegt omtrent lid $8^{439}$ dat, naast betaling van de prijs tegen vrije onbezwaarde levering van de aandelen, consignatie van de prijs met de vervallen rente altijd mogelijk is. Dit is van nut ais de uitgekochte minderheidsaandeelhouders weigeren te leveren, hun aandelen niet onbezwaard zijn of hun adres onbekend is. Consignatie doet de aandelen van rechtswege, vrij

436 De deskundigen hebben inzage in de boeken en bescheiden van de vennootschap, en de bestuurders, commissarissen en werknemers van de vennootschap zijn verplicht aan de deskundigen inlichtingen te verschaffen (art. 351 lid $1 \mathrm{BW}$ ). De eerste drie zinnen van art. 350 lid 3 BW en art. 352 zijn van overeenkomstige toepassing.

437 TK 18904 , or. 3, p. 8.

438 TK 18904 , nr. 3, p. 9.

439 De tekst van lid 8 luidt als volgt: "De ovememer kan zich altijd van zijn verplichtingen ingevolge de leden 6 en 7 bevrijden door de vastgestelde prijs met rente voor alle nog niet overgenomen aandelen te consigneren, onder mededeling van hem bekende rechten van pand en vnuchtgebruik en de hem bekende beslagen. Door deze mededeling gaat het beslag over van de aandelen op het recht op uitkering. Door het consigneren gaat het recht op de aandelen onbezwaard op hem over en gaan rechten van pand of vruchtgebruik over op het recht op uitkering. Aan aandeel- en dividendbewijzen waarop na de overgang uitkeringen betaalbaar zijn gesteld, kan nadien geen recht jegens de vennootschap meer worden ontleend. De ovememer maakt het consigneren en de prijs per aandeel op dat tijdstip bekend op de wijze van lid 7." 
van rechten en lasten, overgaan op de uitkoper. De uitgekochte aandeelhouders krijgen aanspraak op het geconsigneerde bedrag, vermeerderd met de wettelijke rente tot aan de consignatie en vervolgens vermeerderd met de rente volgens de Wet op de consignatie van gelden. De uitkoper is verplicht van de beslagen en van de eventuele rechten van pand en vruchtgebruik die rusten op de uit te kopen aandelen, voorzover hem bekend, opgave te doen aan de beheerder van de consignatiekas. De regel dat door mededeling van een beslag aan de beheerder van de consignatiekas het beslag overgaat op het geconsigneerde bedrag, is ontleend aan art. 455a Invoeringswet Boeken 3-6 NBW (eerste gedeelte). De uitkoper moet de consignatie schriftelijk, danwel in een advertentie, aan de uitgekochte aandeelhouders bekend maken.

\section{II.10.1 Uitkoopregeling en pandrecht}

Teneinde nu te komen tot een analyse van de mogelijke problemen, die zich kunnen voordoen bij uitkoop van aandelen waarop een pandrecht rust, zal eerst, zoals in de inleiding reeds werd aangegeven, het onderzoeksveld worden afgebakend. Aangegeven zal worden welke onderlinge verhoudingen ontstaan wanneer er sprake is van uitkoop van verpande aandelen.

De aandelen in de besloten vennootschap $\mathrm{BV} \mathrm{X}$ worden gehouden door BV $Y$ en $A$ en B. BV Y houdt $93 \%$ van de aandelen, A houdt $4 \%$ en B $3 \%$. BV Y is voornemens $100 \%$ van de aandelen in BV $\mathrm{X}$ te verkrijgen. De aandeelhouders worden door BV $\mathrm{Y}$ benaderd met het verzoek om tegen een redelijke prijs hun aandelen over te dragen. A heeft hier wel oren naar en draagt zijn pakket, met inachtneming van de statutaire blokkeringsbepalingen, over aan BV Y. B daarentegen reageert in het geheel niet. Hij heeft zijn aandelen verpand aan een bank.

BV Y, inmiddels houder van $97 \%$ van de aandelen in BV X, ziet zich genoodzaakt een procedure tot uitkoop van de resterende $3 \%$ aandelen BV X te entameren.

In casu speelt de omstandigheid dat $B$ niet alleen minderheidsaandeelhouder maar ook pandgever is een rol. $\mathrm{Hij}$ heeft als aandeelhouder/pandgever bepaalde verplichtingen jegens de pandhouder. Een drietal relaties kan worden onderscheiden, te weten de relatie tussen uitkoper en de aandeelhouder/pandgever, de verhouding tussen uitkoper en pandhouder en de betrekking tussen de pandgever en de pandhouder.

\section{II.10.2 Relatie uitkoper - aandeelhouder/pandgever}

BV Y wenst over te gaan tot uitkoop van de overige aandelen in BV X. Zij stelt daartoe een vordering in bij de ondernemingskamer en voert aan dat zij houder is 
van $97 \%$ van de aandelen in BV X. Deze stelling wordt niet betwist. De rechter zal dan toetsen of de overgebleven aandeelhouder B ten gevolge van de uitkoop ernstige stoffelijke schade lijdt, danwel houder is van een prioriteitsaandeel en of de uitkopende aandeelhouder jegens de gedaagde mogelijkerwijs afstand heeft gedaan van het recht tot uitkoop. Zijn geen van de genoemde omstandigheden aanwezig dan wijst de rechter de vordering toe.

Vervolgens stelt hij de prijs vast - c.q. laat de prijs vaststellen - die de over te dragen aandelen op een door hem te bepalen dag zullen hebben. Hij veroordeelt de overnemer de vastgestelde prijs met rente te betalen aan de houder van de uit te kopen aandelen. B dient als tegenprestatie het onbezwaarde recht van aandeel te leveren.

Dit zou de normale gang van zaken zijn indien er geen beperkt recht op de aandelen zou rusten. In casu liggen de feiten echter anders. Levering van de met pandrecht bezwaarde aandelen aan BV Y impliceert dat een derdenpand ontstaat. Immers het recht van pand volgt het goed waarop het rust. ${ }^{440}$ Het gevolg hiervan zou zijn dat BV Y een pand geeft voor een schuld van B. Deze situatie kan nadelige gevolgen met zich brengen voor de uitkoper die ongewild derde pandgever zou worden.

Men mag al helemaal niet denken aan de situatie waarin, in dit regime, het stemrecht op de aandelen aan de pandhouder zou zijn overgedragen. De wetgever heeft dan ook gekozen voor een andere aanpak.

Kan de uit te kopen aandeelhouder zijn aandelen niet onbezwaard leveren aan de uitkoper vanwege het feit dat zijn aandelen zijn bezwaard met een pandrecht ${ }^{41}$, dan is de uitkoper bevoegd de door de rechter voor de aandelen vastgestelde prijs met rente te consigneren. Onder consignatie wordt verstaan het overmaken van gelden aan de staat onder de in de Wet op de consignatie van gelden voorgeschreven normen, ter beschikking van degene die van zijn recht op uitkering uit de consignatiekas doet blijken. ${ }^{42}$ In het eerste lid van art. 5 Wet op de consignatie van gelden wordt bepaald dat bij de consignatie aan de desbetreffende ambtenaar bescheiden worden overlegd, danwel toegezonden, waaruit blijkt op grond van welk wettelijk voorschrift, besluit, beschikking of beslissing de consignatie plaatsvindt. Op de uitkoper rust de verplichting de houder van de consignatiekas, veelal de ontvanger van 's Rijksbelastingen, op de hoogte te brengen van de hem bekende rechten van pand die op de aandelen rusten. ${ }^{443}$

Door het consigneren van het door de rechter bepaalde bedrag gaat het recht op de aandelen onbezwaard op de uitkoper over. Het recht van pand gaat van

440 Pitlo/Reehuis, Heisterkamp, Goederenrecht, nr. 757; zie ook H.J. Snijders, E.B. Rank-Berenschot, Goederenrecht, 1994, nr. 513.

441 Dan wel een recht van vruchtgebruik of een beslag, zie art. 201a lid 8 BW.

442 Zie ant. 1 lid 1 onder $c$ Wet op de consignatie van gelden.

$443 \mathrm{Zie}$ art. 201a lid 8; zie ook art. 5 lid 1 tweede volzin Wet op de consignatie van gelden. 
rechtswege over op het recht op uitkering van het in de consignatiekas gestorte bedrag. ${ }^{444}$

Een interessante vraag in het kader van de relatie uitkoper - aandeelhouder/pandgever is de volgende. Kan een minderheidsaandeelhouder ( $\leq 5 \%)$ in een BV door middel van het vestigen van een pandrecht op dat pakket aandelen beletten dat de 95\%-aandeelhouder gebruik maakt van zijn bevoegdheid hem uit te kopen? Men stelle zich het volgende geval voor:

$B$ heeft, zoals wij reeds zagen, zijn aandelen in BV X verpand aan de bank. In de pandakte tussen $B$ en de bank is overeengekomen dat de bank bevoegd is het stemrecht uit te oefenen in de algemene vergadering van BV X.

Deze bepaling is bewust in het contract opgenomen omdat de bank op deze wijze de waarde van het pand mede kan bepalen en in stand houden. Ter versterking van deze bepaling vindt men voorts de contractuele bepaling dat, indien de aandelen waarop het pandrecht rust mochten worden uitgekocht, B zich jegens de bank verplicht additionele zekerheid te stellen.

444 Boeiend is het volgende. In het achtste lid van art. 201a BW wordt bepaald dat de uitkoper zich alrijd van de verplichtingen ingevolge de leden 6 en 7 kan bevrijden door de vastgestelde prijs vermeerderd met rente voor alle nog niet overgenomen aandelen te consigneren. Mijns inziens gaat deze bepaling wel erg ver. Doordat de wetgever bepaalt dat de uitkoper zich altijd kan bevrijden door consignatie kan deze zich in beginsel onttrekken aan de verplichting de uit te kopen aandeelhouder schriftelijk op de hoogte te brengen van de dag en de plaats van de betaalbaarstelling en de te betalen prijs alsmede van deze feiten een aankondiging te doen in een landelijk verspreid dagblad indien de uitkoper de uit te kopen aandeelhouder niet kent. Ik ben van mening dat het woordje altijd uit de betreffende bepaling geschrapt dient te worden. Immers indien de uit te kopen aandeelhouders reageren op de vordering tot uitkoop en hun aandelen aan de uitkoper aanbieden, kan deze laatste simpelweg volstaan met een verwijzing naar de consignatiekas alwaar de aandeelhouders hun geld kunnen ophalen. Op deze wijze kan de uitkoper voorbij gaan aan de wettelijke vereisten die aan de overdracht van aandelen zijn gesteld (zie ook P. van Schilfgaarde, WPNR 5911 (1989), p. 212. Schrijver bepleit de verwijzing naar lid 7 in ieder geval te schrappen). Bij de uitkering wordt, over het geconsigneerde bedrag, rente vergoed (aldus art. 9 Wet op de consignatie van gelden). De hoogte van het rentepercentage wordt jaarlijks vastgesteld door de Minister van Financiēn. De rente begint te lopen met ingang van de eerste dag van de maand die volgt op de maand waarin de gelden door de houder van de consignatiekas zijn ontvangen. Zij wordt berekend tot en met de laatste dag van de maand, voorafgaande aan de maand van uitkering, dan wel tot en met de laatste dag van de maand voorafgaande aan die waarin de rechtsvordering tot uitkering is verjaard (art. 10 Wet op de consignatie van gelden bepaalt dat de rechtsvordering tot uitkering vervalt door verloop van twintig jaren na de consignatie). Voor de berekening van de te betalen rente wordt uitgegaan van het aantal hele guldens waaruit de geconsigneerde som bestaat. Onderdelen van guldens, het bedrag achter de komma, worden verwaarloosd. 
Ingeval de grootaandeelhouder nu een vordering tot uitkoop instelt zal B, wil hij zijn overeenkomst met de bank nakomen, extra zekerheid moeten stellen.

De rechter zal nagaan of een van de omstandigheden die genoemd worden in het vierde lid van art. 201a BW aanwezig is. Uit de geschetste casus blijkt niet dat B houder is van een aandeel waaraan bijzondere zeggensmacht is verbonden. Eveneens is niet duidelijk of BV Y jegens B afstand heeft gedaan van haar recht tot uitkoop van minderheidsbelangen. De rechter kan de vordering van BV $\mathrm{Y}$ in dit geval alleen dan afwijzen indien aangetoond kan worden dat B ten gevolge van de overdracht en ondanks de te verstrekken vergoeding ernstige stoffelijke schade lijdt. Volgens de MvT moet dit nadeel bestaan uit een financieel nadeel. De gevoelsband die een kleine aandeelhouder met de vennootschap heeft is geen grond voor verweer. ${ }^{45}$ Voorstelbaar is, naar mijn mening, dat de rechter de contractuele verplichting van $B$ jegens de bank, tot het verstrekken van extra zekerheid, zal beoordelen als een ernstige stoffelijke schade die door B wordt geleden. De rechter zal alsdan de vordering tegen alle gedaagden (i.c. B) afwijzen. Het gevestigde pandrecht staat in dit geval het recht tot uitkoop in de weg.

De vraag of de houder van een pandrecht op de uit te kopen aandelen ernstig stoffelijk nadeel lijdt is in het kader van lid 4 van art. 92a/201a BW niet relevant. Dit lijkt mij terecht, anders kan men door vestiging van een pandrecht de mogelijkheid van de uitkoop frustreren. Wel lijkt mij, onder uitzonderlijke omstandigheden, verdedigbaar dat het gebruik maken van het wettelijk verankerd recht op uitkoop strijd oplevert met de regeling van de redelijkheid en billijkheid die de relatie meerderheidsaandeelhouder-minderheidsaandeelhouder op grond van art. $8 \mathrm{BW}$ beheerst. Men denke aan de volgende situatie. In ons voorbeeld draagt de minderheidsaandeelhouder $B$ het stemrecht op zijn aandelen over aan zijn crediteur, welke overdracht een harde voorwaarde is voor het verkrijgen van de lening. Stel dat de 97\% aandeelhouder BV Y van deze omstandigheden op de hoogte is en, in het kader van de statutaire regeling betrekkelijk de overdracht van het stemrecht bij de verpanding, als aandeelhouder in de algemene vergadering voor die overdracht stemt. Zou dan, het direct daarna gebruik maken van het recht op uitkoop, met alle genoemde nadelen voor de minderheidsaandeelhouder waar het betreft het handhaven van zijn kredietpositie, niet onbillijk kunnen zijn? Men zou zich kunnen afvragen of onder die omstandigheden een afspraak tussen de $97 \%$ aandeelhouder en de $3 \%$ pandhouder met stemrecht, waarbij wordt overeengekomen dat de $97 \%$ aandeelhouder niet tot uitkoop zal overgaan, in de weg staat aan het instellen van een uitkoopvordering jegens de houder van het 3\%-pakket. Afgezien van wanprestatie in de relatie meerderheidsaandeelhouderpandhouder, staat deze overeenkomst naar mijn mening niet in de weg aan het

445 TK 18 904, MvT op art. 92a lid 4 BW. 
instellen van de uitkoopactie, nu de afstand van het recht niet plaatsvond tussen uitkoper en gedaagde in de zin van het vierde lid van art. 92a/201a BW.

\section{II.10.3 Relatie uitkoper - pandhouder}

Tengevolge van het feit dat aan de uitkoper de wettelijke bevoegdheid is toegekend de prijs van de uitgekochte aandelen te consigneren om aldus het onbezwaarde recht op de aandelen te verkrijgen, zal in de praktijk niet gauw sprake zijn van een juridische relatie tussen uitkoper en pandhouder. Het pandrecht dat ten behoeve van de pandhouder werd gevestigd op de, inmiddels uitgekochte, aandelen komt immers te rusten op het geconsigneerde bedrag. De uitkoper verkrijgt het onbezwaarde recht op de aandelen. Het uitgekochte aandeel is dus niet langer onderwerp van verpanding. Dit zal dus logischerwijs betekenen dat, wanneer de pandhouder met de pandgever was overeengekomen dat de eerstgenoemde het stemrecht verbonden aan de verpande aandelen zou toekomen, de pandhouder de bevoegdheid tot het uitoefenen van het stemrecht verliest. De enige zekerheid die de pandhouder rest is het geconsigneerde bedrag waarop hij van rechtswege een pandrecht heeft verkregen. Het zou immers volstrekt in strijd zijn met de ratio van de uitkoopregeling wanneer de uitkoper, die erin geslaagd is $100 \%$ van de aandelen in een vennootschap te verkrijgen, geconfronteerd wordt met aanspraken van derden ter zake van de uitgekochte aandelen.

Vervolgens zou men zich de vraag kunnen stellen of, wanneer er al geen juridische betrekking tussen de uitkoper en de pandhouder zal bestaan, een feitelijke verhouding denkbaar zou kunnen zijn. Met deze feitelijke verhouding doel ik op de vereniging van twee actoren in een natuurlijk (c.q. rechts-) persoon. Kan een pandhouder die $95 \%$ of meer van de aandelen in een vennootschap in pand houdt een vordering tot uitkoop jegens de houders van de overige aandelen in het kapitaal van de vennootschap entameren?

De wet is hierin duidelijk. In het eerste lid van art. 92a/201a BW lezen we:

\footnotetext{
"Hij die als aandeelhouder voor eigen rekening ten minste $95 \%$ van het geplaatste kapitaal van de naamloze vennootschap verschaft, kan tegen de gezamenlijke andere aandeelhouders een vordering instellen tot overdracht van hun aandelen aan de eiser."
}

Een pandhouder zal in die kwaliteit dus nimmer gerechtigd zijn een vordering op basis van de uitkoopregeling in te stellen. Het zal altijd moeten geschieden door een aandeelhouder die voor eigen rekening aandelen houdt en voldoet aan de $95 \%$-eis.

Het is natuurlijk wel mogelijk dat een aandeelhouder, die voldoet aan de eisen van art. 92a/201a lid $1 \mathrm{BW}$ en tevens houder is van een pandrecht op de overige aandelen in de vennootschap, een vordering tot uitkoop entameert. Hij doet dit 
dan in de hoedanigheid van aandeelhouder en niet in zijn kwaliteit van pandhouder.

We komen dan in de aardige situatie terecht waarin de houder van een pandrecht op een pakket aandelen, rechthebbende wordt op die aandelen. Wat gebeurt er dan met het pandrecht en de vordering tot welker zekerheid het gevestigde pandrecht strekte? Naar mijn mening gaat het pandrecht teniet. Een van de gronden die kunnen leiden tot het tenietgaan van een beperkt recht is immers de vermenging van de persoon van de schuldeiser met die van de eigenaar van het verpande goed. ${ }^{446}$

Als ik goed zie zal de feitelijke toestand ten aanzien van de vordering de volgende zijn. De 95\%-aandeelhouder heeft een vordering, bijvoorbeeld uit geldlening, op de 5\%-aandeelhouder. Deze verleent aan de groot-aandeelhouder een pandrecht op zijn pakket. Op enig moment start de groot-aandeelhouder een procedure op grond van de uitkoopregeling. Wanneer het $5 \%$ pakket in handen van de groot-aandeelhouder geraakt, komt het pandrecht te vervallen. Of de vordering van de groot-aandeelhouder op de vroegere pandgever eveneens komt te vervallen zal afhankelijk zijn van de waarde van de aandelen die in zijn vermogen vloeit. Is het bedrag van de vordering gelijk aan de vastgestelde waarde van de uitgekochte aandelen dan zal verrekening plaatsvinden en zal de vordering dientengevolge tenietgaan. Wanneer de vastgestelde prijs lager is dan het bedrag van de vordering behoudt de uitkoper een restvordering op de minderheidsaandeelhouder. Desgewenst zal de uitkoper hiervoor opnieuw zekerheid kunnen bedingen. Heeft het $5 \%$ pakket een overwaarde, anders gezegd, is de waarde van het aandelenpakket groter dan het bedrag van de vordering, dan zal de uitkoper het surplus aan zijn schuldenaar moeten terugbetalen.

In deze situatie zou het zeer wel denkbaar zijn dat, op het moment van de uitkoop, de vordering, op basis van de leningsovereenkomst, niet opeisbaar is. De hier geschetste structuur, inclusief het vervallen van het pandrecht zou dan een einde maken aan het zekerheidsrecht. Men komt er dan ook niet door art. 3:229 BW van toepassing te verklaren. Er zal dan nieuwe zekerheid bedongen moeten worden.

\section{II.10.4 Relatie pandgever - pandhouder}

De relatie tussen de pandgever/aandeelhouder en de pandhouder is een complexe. De verhouding wordt beheerst door de wettelijke regels en de bepalingen in de tussen partijen gesloten pandakte. De verhouding tussen partijen wordt danig verstoord wanneer een vordering tot uitkoop zich uitstrekt tot de in pand gegeven aandelen.

446 art. 3:81 lid 2 onder e BW. 
Hiervoor zagen wij reeds dat in het geval waarin een vereniging plaatsvindt van 95\%-aandeelhouder/pandhouder/uitkoper in een persoon het gevestigde pandrecht komt te vervallen wanneer de uit te kopen - bezwaarde - aandelen in de macht van de uitkoper geraken.

In $\S$ II. 10.2 werd, in het geval waarin de uitkoper niet tevens pandhouder is, opgemerkt dat de uitkoper overeenkomstig lid 8 van art. 92a/201a BW bevoegd is de vastgestelde prijs met rente voor alle nog niet overgenomen aandelen te consigneren onder vermelding van de bem bekende rechten van pand. Hierdoor gaat het onbezwaarde recht op de aandelen over op de uitkoper en komt het recht van pand te rusten op het recht op uitkering uit de consignatiekas.

Maakt de uitkoper geen gebruik van de hem geboden bevoegdheid tot consignatie van de prijs, dan dient hij, met inachtneming van lid 7 van art. 92a/201a BW, aan degenen aan wie de aandelen toebehoren de prijs met rente te betalen. Wat betekent dit nu voor de verhouding tussen de pandhouder en pandgever?

Op grond van de overeenkomst tot verpanding tussen beide partijen verkreeg de pandhouder een zekerheidsrecht op aandelen die toebehoorden aan de pandgever. In de akte waarbij het pandrecht werd gevestigd kon bepaald zijn dat het stemrecht verbonden aan de verpande aandelen aan de pandhouder zou toekomen. Hierdoor werd het zekerheidsrecht van de pandhouder min of meer versterkt. Door uitoefening van het stemrecht kon hij er immers mede op toezien dat de waarde van de in pand genomen aandelen niet onnodig zou verminderen.

Ten gevolge van de toepassing van de uitkoopprocedure door een groot-aandeelhouder zien zowel pandhouder als pandgever hun rechtsrelatie, buiten hun toedoen, ingrijpend veranderen. De pandgever/aandeelhouder ziet de aandelen uit zijn vermogen verdwijnen, daarvoor in de plaats komt de prijs die de uitkoper voor de aandelen betaalt. De pandhouder dient te accepteren dat zijn zekerheidsobject van aard verandert. 447

In het eerste lid van art. 3:229 BW wordt bepaald dat het recht van pand van rechtswege een recht van pand mee brengt op alle vorderingen tot vergoeding die in plaats van het verbonden goed treden. Naar mijn mening leidt dit in deze situatie ertoe dat het pandrecht overgaat op de uitkering die de uitgekochte aandeelhouder/pandgever van de uitkoper ontvangt. Er ontstaat van rechtswege een pandrecht op het geld, de prijs die de uitkoper voor de uitgekochte aandelen aan de pandgever/ex-aandeelhouder ter beschikking stelt.

Kon de pandhouder voordat de verpande aandelen werden uitgekocht, door middel van de uitoefening van het aan de verpande aandelen verbonden stemrecht, er nog op toezien dat de waarde van zijn pand in tact bleef, thans rest hem slechts een pandrecht op geld. Blijft dit pand in de macht van de pandgever dan

447 Men bedenke bovendien dat de pandhouder zijn stemrecht in de algemene vergadering van aandeelhouders verliest. 
lijkt mij de vrees van de pandhouder dat zijn bedongen zekerheid ernstig aan kracht inboet zeer gerechtvaardigd. Afgifte van het pand zie ik dan ook als de meest voor de hand liggende optie om dit te voorkomen. ${ }^{448}$

Men zou zich eveneens de vraag kunnen stellen of deze relatie met zich mee brengt dat de pandgever/aandeelhouder zich, op verzoek van de pandhouder, moet verzetten tegen de uitkoop? Duidelijk is dat onder deze omstandigheden aandeel wordt geld, stemrecht van de pandhouder komt te vervallen - de omvang van de zekerheid negatief wordt beīnvloed. ${ }^{449} \mathrm{Mij}$ lijkt dan ook, onder omstandigheden, de stelling verdedigbaar dat de aandeelhouder/pandgever zich inderdaad op verzoek van de pandhouder zal dienen te verzetten tegen de effectuering van de uitkoop. In het verlengde van deze stellingname lijkt mij eveneens verdedigbaar dat de aandeelhouder/pandgever dient te vermijden dat een uitkoop überhaupt tot de mogelijkheden gaat behoren. Men denke aan de situatie waarin een $10 \%$ aandeelhouder $5 \%$ van zijn aandelenbezit, bijvoorbeeld met overdracht van stemrecht, heeft verpand. De overdracht van het $5 \%$ onbezwaard pakket aan de $90 \%$ aandeelhouder in de vennootschap creëert, afgezien van situaties als bedoeld in het vierde lid van art. 92a/201a BW, het gevaar van een uitkoopactie. In al deze omstandigheden, waarin de pandgever de omvang van de door hem verleende zekerheid negatief beïnvloedt, zulks zonder overleg met danwel tegen de uitdrukkelijke wens van de pandhouder, zou ik menen dat de pandhouder afgifte van het pand kan vorderen op basis van het derde lid van art. 3:237 BW. Ook buiten deze bijzondere omstandigheden, dus de situatie waarin de pandgever deze uitkoop niet kan voorkomen, zou ik menen dat de pandhouder deze afgifte kan verlangen. Of deze afgifte de uitkoop kan frustreren is de vraag, nu in veel gevallen de uitkoopactie tegen de pandhouder, die aldus eigenaar van het aandeel is geworden, zal kunnen worden ingesteld. Dit zou echter anders liggen in de situatie waarin de aandeelhouder/pandgever $10 \%$ van de aandelen houdt terwijl die $10 \%$ met een beperkt recht is bezwaard en hij in die situatie $5 \%$ van zijn (verpande) aandelen wenst over te dragen aan de $90 \%$ aandeelhouder in die vennootschap.

Zoals al werd opgemerkt zal deze negatieve beïnvloeding van de zekerheidspositie van de pandhouder zich slechts doen gelden wanneer het, in het kader van de uitkoopprocedure, betaalde bedrag geringer is dan het bedrag van de vordering van de pandhouder. Men denke hier aan de situatie waarin de aandelen tot

448 Alsdan vindt art. 3:255 BW toepassing. Op het moment van het opeisbaar worden van de vordering, of zoveel eerder wanneer de pandgever in verzuim is met de voldoening van hetgeen waarvoor het pand tot waarborg strekt, is de pandhouder bevoegd, zonder voorafgaande aanzegging. zich uit het pand te voldoen. Hierdoor zal dan een einde komen aan de rechtsverhouding tussen de pandhouder en de pandgever.

449 Dit zal in ieder geval zo zijn wanneer het krachtens de uitkoopprocedure betaalde bedrag geringer is dan het oorspronkelijk te vorderen bedrag. 
zekerheid worden verpand op een moment waarop de waarde van die aandelen het bedrag van de lening dekte, terwijl op het moment van de uitkoop dit niet meer het geval is. Ook kan men denken aan de situatie waarin verpanding van aandelen plaatsvindt als onderdeel van een veel verstrekkender kredietarrangement, terwijl het stemrecht op die aandelen aan de pandhouder werd overgedragen. 


\section{II.11 De geschillenregeling in relatie tot in pand gegeven aandelen}

\section{II.11.1 Inleiding}

In het navolgende wordt aandacht besteed aan de geschillenregeling ${ }^{450}$, opgenomen in de eerste afdeling van de achtste titel van Boek 2 BW. Het doel van de geschillenregeling is het oplossen van bepaalde conflicten die zijn ontstaan tussen aandeelhouders onderling of tussen aandeelhouders en stemgerechtigde vruchtgebruikers en pandhouders. De regeling is van toepassing op besloten vennootschappen met beperkte aansprakelijkheid en op zogenaamde besloten naamloze vennootschappen. ${ }^{451}$ De regeling bestaat uit een drietal onderdelen. Allereerst is daar de bepaling van art. $336 \mathrm{BW}$. Zij ziet op de gedwongen overdracht van aandelen in het belang van de vennootschap. Een of meer houders van aandelen die alleen of gezamenlijk ten minste een derde van het geplaatste kapitaal verschaffen, kunnen van een aandeelhouder die door zijn gedragingen het belang van de vennootschap zodanig schaadt, dat het voortduren van zijn aandeelhouderschap in redelijkheid niet kan worden geduld, vorderen dat hij zijn aandelen aan hem (hen) overdraagt. In de tweede plaats kunnen een of meer aandeelhouders, die voldoen aan de hierboven gestelde kapitaaleis, conform art. 342 BW van een stemgerechtigde vruchtgebruiker of pandhouder vorderen dat het stemrecht verbonden aan de aandelen overgaat op (terugkeert bij) de houder van het aandeel, indien die vruchtgebruiker of pandhouder door zijn gedragingen het belang van de vennootschap zodanig schaadt dat in redelijkheid niet kan worden geduld dat hij het stemrecht blijft uitoefenen.

Tenslotte kent de geschillenregeling de vordering tot overname van aandelen in het belang van de aandeelhouder. Art. $343 \mathrm{BW}$ bepaalt dat de aandeelhouder die door gedragingen van een of meer mede-aandeelhouders zodanig in zijn rechten of belangen wordt geschaad dat het voortduren van zijn aandeelhouderschap in redelijkheid niet van hem kan worden gevergd, van die mede-aandeelhouders kan vorderen dat zijn aandelen worden overgenomen. De tekst van de wet is duidelijk. Een stemgerechtigde pandhouder kan deze actie derhalve niet instellen, nu het criterium niet de zeggensmacht maar de kapitaalverschaffing is.

450 Ingevoerd bij Wet van 10 november 1988, Stb. 1988, 516.

451 Dit zijn die naamloze vennootschappen waarvan de statuten vitsluitend aandelen op naam kennen, een blokkeringsregeling bevatten en niet toelaten dat met medewerking van de vennootschap certificaten aan toonder worden uitgegeven; zie art. 335 lid $2 \mathrm{BW}$. 
In het kader van dit onderzoek zullen met name enkele aspecten worden belicht die zich bevinden op het raakvlak tussen de wettelijke regeling van de geschillenbeslechting en het pandrecht gevestigd op aandelen. Hierbij kan gedacht worden aan de positie van de pandhouder wanneer de aandeelhouder, die zijn aandelen aan hem in pand gegeven heeft, wordt geconfronteerd met een vordering tot overdracht, danwel zelf een vordering tot overname van zijn aandelen instelt. Voorts zal de positie van de pandhouder worden bezien wanneer jegens hem een vordering tot overdracht van het stemrecht wordt ingesteld. Alvorens nader in te gaan op de positie van de pandhouder zal eerst kort aandacht worden besteed aan de verschillende aspecten van de geschillenregeling, te weten de uitstoting, de uittreding en de gedwongen overgang van het stemrecht.

\section{II.11.2 Uitstoting, uittreding en vordering tot overgang van het stemrecht}

\section{a. Uitstoting}

Wanneer een aandeelhouder door zijn gedragingen het belang van de vennootschap op een zodanige wijze schaadt, dat het voortduren van zijn aandeelhouderschap in redelijkheid niet kan worden geduld, kunnen een of meer aandeelhouders ${ }^{42}$, die alleen of tezamen een derde van het geplaatste kapitaal van de vennootschap verschaffen, in rechte van deze aandeelhouder vorderen dat hij zijn aandelen overdraagt. In lid 2 van art. 336 BW wordt bepaald dat de vordering niet kan worden ingesteld door de vennootschap of een dochtermaatschappij van de vennootschap. De vordering dient te worden ingesteld bij de rechtbank van de woonplaats van de vennootschap. Hoger beroep dient te worden ingesteld bij de ondernemingskamer van het Gerechtshof te Amsterdam. Grondslag voor de vordering is het gedrag van de aandeelhouder als zodanig waardoor het belang van de vennootschap wordt geschaad. Die gedragingen die weliswaar schadelijk zijn voor de vennootschap maar "die niet direct verband houden met het functioneren van de aandeelhouder binnen de vennootschap kunnen geen aanleiding zijn voor een vordering tot uitsluiting. ${ }^{\text {na53 }}$

De aandelen moeten door de aandeelhouder conform het bepaalde in art. 341 BW worden overgedragen. De gedaagde aandeelhouder is verplicht binnen twee weken nadat aan hem het afschrift van het onherroepelijk geworden vonnis waarin de prijs van de aandelen wordt vastgesteld en tevens wordt bepaald wie van de partijen de kosten van het deskundigenbericht moet dragen - is betekend, de aandelen tegen gelijktijdige betaling te leveren aan de eiser(s). De leden 2 en 3 van art. 341 BW regelen de wijze van overdracht van de aandelen indien een

452 Voor het geval waarin de eiser aandeelhouder ten titel van beheer is, verwijs ik naar F.J.P. van den Ingh, diss. p. 222-235.

453 Rechtspersonen, M.J.G.C. Raaijmakers, aantekening 4 bij art. 336, p. 336-7. 
aanbiedingsblokkade in de statuten van de vennootschap is opgenomen. De vennootschap levert namens de gedaagde aandeelhouder de aandelen wanneer hij in gebreke blijft met de levering. In het geval een of meer eisers in gebreke blijven met de aanvaarding van de aandelen tegen gelijktijdige betaling van de vastgestelde prijs, dan legt de wet op de overige eisers de plicht binnen een termijn van twee weken die aandelen tegen gelijktijdige betaling te aanvaarden. Aanvaarding geschiedt zoveel mogelijk naar rato van aandelenbezit.

\section{b. Uittreding}

Doet de situatie zich voor waarin de rechten of belangen van een aandeelhouder door de gedragingen van een of meer van zijn mede-aandeelhouders zodanig worden geschaad dat het voortduren van zijn aandeelhouderschap in redelijkheid niet van hem kan worden gevergd, dan kan hij van zijn mede-aandeelhouders vorderen dat zijn aandelen worden overgenomen. Het gaat hier, in tegenstelling tot de uitstotingsprocedure, niet om het belang van de vennootschap maar om het belang van de aandeelhouder dat wordt geschaad. Binnen twee weken nadat het onherroepelijk geworden vonnis aan de gedaagde is betekend, is hij verplicht het vastgestelde aantal aandelen tegen gelijktijdige betaling van de prijs over te nemen en is de eiser verplicht zijn aandelen te leveren. De leden 4 en 5 van art. $343 \mathrm{BW}$ geven wederom een regeling voor het geval van een statutaire aanbiedingsblokkade. Wanneer de eiser met de levering van zijn aandelen in gebreke blijft, levert de vennootschap namens hem tegen gelijktijdige betaling. Aanvaarden een of meerdere gedaagden de aandelen niet, dan zijn de overige gedaagden verplicht die aandelen tegen gelijktijdige betaling over te nemen.

\section{c. Gedwongen stemrecht overgang}

De derde procedure die deel uitmaakt van de geschillenregeling is te vinden in art. $342 \mathrm{BW}$ en regelt de gedwongen overgang van het stemrecht. Een of meer houders van aandelen die alleen of tezamen minimaal een derde van het geplaatste kapitaal van de vennootschap verschaffen, kunnen van een stemgerechtigde pandhouder vorderen dat het stemrecht verbonden aan het in pand geven aandeel overgaat op de houder van het aandeel. Deze actie kan worden ingesteld indien de pandhouder door zijn gedragingen het belang van de vennootschap zodanig schaadt dat in redelijkheid niet kan worden geduld dat hij het stemrecht blijft uitoefenen. Indien de vordering tot overgang van het stemrecht wordt toegewezen, vindt de feitelijke overgang plaats door het in kracht van gewijsde gaan van het vonnis. 
II.11.3 Positie van de pandhouder in geval van uitstoting, uittreding en gedwongen overgang van het stemrecht

Zowel in geval van de uitstoting als van de uittreding wordt gesproken van de aandeelhouder. Enerzijds de aandeelhouder die door zijn gedragingen het belang van de vennootschap schaadt, anderzijds de aandeelhouder wiens rechten en belangen door gedragingen van een of meerdere mede-aandeelhouders worden geschaad. De wettelijke geschillenregeling houdt geen rekening met het feit dat de aandeelhouder die geconfronteerd wordt met een procedure op grond van deze bepalingen zijn aandelen met een beperkt recht bezwaard zou kunnen hebben. De wet besteedt geen aandacht aan de positie van de houder van een beperkt recht op aandelen ${ }^{454}$, die krachtens de regeling van de uitstoting of de uittreding van eigenaar veranderen. In tegenstelling tot de uitkoopregeling, alwaar in art. 92a/201a lid 6 BW ondubbelzinnig wordt bepaald dat de uitkoper tegen betaling van de vastgestelde prijs recht heeft op levering van het onbezwaard recht op aandeel, bevat de geschillenregeling geen soortgelijke oplossing. De positie van de pandhouder blijft dus in het ongewisse. Laten wij deze positie in de drie aangegeven gevallen bezien.

\section{a. De positie van de pandhouder in geval van een uitstotingsprocedure}

Wanneer een aandeelhouder, die zijn aandelen in pand heeft gegeven, zich gesteld ziet voor een vordering op basis van de uitstotingsregeling van art. 336 BW, kan een drietal actoren worden onderscheiden. Allereerst is daar de aandeelhouder die ten gevolge van zijn gedragingen wordt geconfronteerd met een vordering tot overdracht van zijn aandelen. In de tweede plaats de eisers, die van de aandeelhouder vorderen dat hij zijn aandelen aan hen overdraagt. Tenslotte de houder van een pandrecht op de aandelen, die onderwerp zijn geworden van de gedwongen overdracht.

De verschillende belangen van de actoren zullen in het algemeen met elkaar strijden. De aandeelhouder die verplicht wordt zijn aandelen over te dragen zal gebaat zijn bij een zo hoog mogelijke prijs. De pandhouder zal er op toe willen zien dat zijn bedongen zekerheid niet teloor gaat. De eisers tot overdracht zullen aandelen willen verkrijgen vrij van rechten en aanspraken van derden.

Naar mijn mening dient met betrekking tot de positie van de pandhouder, die met een uitstotingsprocedure wordt geconfronteerd, een onderscheid te worden gemaakt tussen het geval waarin de pandhouder niet het stemrecht verbonden aan de verpande aandelen kan uitoefenen en het geval waarin hij dat wel kan.

454 Behoudens de hiema te bespreken regeling van art. 342 BW alwaar de vordering tot overdracht van het stemrecht van de pandhouder (en vruchtgebruiker) wordt behandeld. 
In het geval van een uitstotingsprocedure zullen zowel de aandeelhouder als de pandhouder zonder stemrecht weinig kunnen uitrichten tegen de vordering tot overdracht en levering van de aandelen. De actie wordt immers geëntameerd door een of meerdere mede-aandeelhouders die alleen of tezamen tenminste een derde van het geplaatste kapitaal van de vennootschap verschaffen. Goederenrechtelijk bezien zal bij overdracht van het bezwaarde aandeel het beperkte recht het over te dragen aandeel volgen, dit ten gevolge van het droit de suite van het beperkte recht. ${ }^{455}$ Dit zou betekenen dat de eiser(s) tot overdracht van de aandelen een met een beperkt recht van pand bezwaard goed verkrijgen. Terwijl de aandeelhouder, die zijn aandelen gedwongen overdraagt, de vastgestelde prijs in ontvangst kan nemen. Het pandrecht verandert dan van karakter en wordt een derden-pand. ${ }^{456}$ Voor de pandhouder zou dit onder omstandigheden wel verteerbaar zijn. Zijn vordering blijft immers gesecureerd door een pandrecht, zij het in dit geval een derden-pandrecht. Degene die de aandelen krachtens de uitstootprocedure verkrijgt en geconfronteerd wordt met het op de aandelen rustende pandrecht, wordt naar mijn mening voor grote problemen geplaatst. Voor hem dreigt het gevaar dat zijn aandelen uitgewonnen worden wanneer de schuldenaar verzuimt zijn verplichtingen jegens de pandhouder na te komen. Zijn lidmaatschapsbetrekking tot de vennootschap wordt mede afhankelijk van de juridische bevoegdheden van een derde, i.c. de pandhouder. Dit dient mijns inziens te worden voorkomen.

Ik zou dan ook willen verdedigen dat in de wettelijke bepaling betreffende de uitstotingsprocedure wordt opgenomen dat de aandelen, die krachtens art. 336 jo $341 \mathrm{BW}$ tegen gelijktijdige betaling aan de eiser worden overgedragen, onbezwaard, dus vrij van beperkte rechten, in diens vermogen vloeien. Het pandrecht dat op de aandelen rustte zou dan, krachtens art. 3:229 BW, komen te liggen op het aan de aandeelhouder uitgekeerde bedrag. Dit bedrag zou dan aan de pandhouder moeten worden afgedragen. ${ }^{457}$

Hoe nu te oordelen over de positie van de pandhouder die wel gerechtigd is het stemrecht verbonden aan de verpande aandelen uit te oefenen?

Alvorens deze vraag te beantwoorden een opmerking over de tekst van het eerste lid van art. $336 \mathrm{BW}$.

455 Zie H.J. Snijders, E.B. Rank-Berenschot, Goederenrecht, ar. 459.

456 Zie H.J. Snijders, E.B. Rank-Berenschot, Goederenrecht, nr. 513.

457 Zie ook Handboek (1992), nr. 357. Aldaar lezen we: "(...) dat de koopprijs aan de pandhouder wordt afgedragen tot het bedrag van zijn vordering $(\ldots)^{n}$. Dit lijkt mij niet noodzakelijk. De pandhouder zou naar mijn mening het gehele bedrag in ontvangst kunnen nemen. Immers, in art. 3:255 jo $253 \mathrm{BW}$ wordt bepaald dat de pandhouder zonder voorafgaande aanzegging bevoegd is zich uit het pand te voldoen, en het eventuele overschot aan de pandgever uit te keren. Het gevaar van overbedeling van de pandhouder is daarmee ondervangen. 
"Een of meer houders van aandelen die alleen of gezamenlijk ten minste een derde van het geplaatste kapitaal verschaffen, kunnen van een aandeelhouder die door zijn gedragingen (curs.JH) het belang van de vennootschap zodanig schaadt, dat het voortduren van zijn aandeelhouderschap in redelijkheid niet kan worden geduld, in rechte vorderen dat hij zijn aandelen overeenkomstig artikel 341 overdraagt."

Grondslag voor het instellen van de procedure tot uitstoting is dus de gedraging van de aandeelhouder waardoor het belang van de vennootschap wordt geschaad. Aan welke gedragingen moeten wij nu denken? Het moet gaan om gedragingen die schadelijk zijn voor de vennootschap en die direct verband houden met het functioneren van de aandeelhouder binnen de vennootschap. ${ }^{458}$ In de $\mathrm{MvT}^{459}$ wordt opgemerkt dat het moet gaan om gedragingen van aandeelhouders die er toe leiden dat de samenwerking in een besloten vennootschap of besloten naamloze vennootschap ernstig bemoeilijkt wordt. We lezen verder:

\begin{abstract}
"Het kan zijn dat groepen aandeelhouders tegenover elkaar staan, waardoor de besluitvorming in de vennootschap niet meer mogelijk is en een goede gang van zaken wordt belemmerd. Het kan ook zijn dat een minderheid van aandeelhouders door de meerderheid in een onhoudbare positie wordt gebracht. Moeilijkheden kunnen zich vooral voordoen in familievennootschappen. Daarin voelen de aandeelhouders zich nauwer betrokken bij de gang van zaken dan aandeelhouders die uitsluitend uit beleggingsoverwegingen een aandeel kopen. De onenigheid kan hoog oplopen, in het bijzonder wanneer uit tegengestelde kampen bestuurders worden benoemd die de strijd tussen de aandeelhouders in het bestuur voortzetten of wanneer de aandeelhouders tevens bestuurder zijn."
\end{abstract}

De gedragingen van de aandeelhouder die het belang van de vennootschap schaden zullen dus veelal bestaan uit het op een bepaalde - schadelijke - wijze uitoefenen van het stemrecht, danwel het juist niet uitoefenen van het stemrecht in die gevallen waarin het noodzakelijk is.

In het geval waarin het stemrecht is toegekend aan de pandhouder zal het echter niet het stemgedrag van de aandeelhouder/pandgever kunnen zijn waardoor het belang van de vennootschap wordt geschaad. Simpelweg omdat deze geen stemrecht kan uitoefenen. Wanneer de pandhouder het stemrecht verbonden aan de verpande aandelen kan uitoefenen zal de uitstotingsprocedure niet direct relevant zijn. Immers, het moet gaan om gedragingen van de aandeelhouder die het belang van de vennootschap schaden. Is het het gedrag van de stemgerechtigde pandhouder waardoor het belang van de vennootschap wordt geschaad, dan kan de pandhouder wel geconfronteerd worden met een vordering op basis van art. $342 \mathrm{BW}$. Het feit dat hij alsdan zijn stemrecht kan verliezen is volledig aan zijn eigen gedrag te wijten.

458 Rechtspersonen, M.J.G.C. Raaijmakers, aantekening 4 bij art. 336, p. 336-8.

459 J.M.M. Maeijer, Wetsgeschiedenis, p. DXy-7. 
Denkbaar is de situatie waarbij een uitstotingsprocedure wordt ingesteld tegen een aandeelhouder/pandgever die geen stemrecht heeft, maar die door andere gedragingen het belang van de vennootschap schaadt. ${ }^{460}$ In dit geval heeft de vordering dus in het geheel niets uit te staan met het (stem)gedrag van de pandhouder en verdient deze - mijns inziens - de gelijke bescherming als hiervoor beschreven voor het geval waarin de pandhouder geen stemrecht toekomt.

\section{b. De positie van de pandhouder in geval van een uittredingsprocedure}

Ten aanzien van de uittreding c.q. de gedwongen overname in relatie tot de positie van de pandhouder kan het volgende worden opgemerkt. Ging bij de uitstotingsprocedure het initiatief uit van 'een of meerdere aandeelhouders', bij de uittreding is het de aandeelhouder/pandgever zelf die zijn aandelen in de uitverkoop gooit en hiermee dus de positie van de pandhouder op het spel zet.

Vooropgesteld moet worden dat in de wettelijke regeling ten aanzien van de uittreding, in beginsel, geen rol is weggelegd voor de pandhouder. De actie gaat, zoals gezegd, geheel en al uit van de aandeelhouder die in zijn belangen wordt geschaad door gedragingen van een of meer aandeelhouders. Dit zal zeker het geval zijn wanneer de pandhouder niet het stemrecht verbonden aan de verpande aandelen kan uitoefenen. Onder deze omstandigheden dient de pandhouder - naar mijn mening - dezelfde bescherming ten deel te vallen als bij de gedwongen overdracht van aandelen.

Echter, zover hoeft het mijns inziens niet te komen. Voorstelbaar lijkt mij het geval dat de pandhouder en de pandgever in de pandakte overeenkomen dat de pandgever afstand doet van zijn rechten uit art. $343 \mathrm{BW}$. Eveneens lijkt mij verdedigbaar dat de pandhouder en de pandgever afspreken dat de pandhouder, op het moment waarop de pandgever een actie op grond van de uittredingsprocedure wil entameren, kan vorderen dat hem het stemrecht verbonden aan de in pand gegeven aandelen toekomt. Bij een 'besloten' naamloze vennootschap lijkt mij dat een beding als hier omschreven rechtsgeldig kan worden gemaakt, gelet op hetgeen wordt bepaald in de slotzin van art. 89 lid $3 \mathrm{BW}$. Bij een besloten vennootschap acht ik een dergelijke afspraak in strijd met de wet. ${ }^{46 !}$

Anders is het wanneer de pandhouder wel gerechtigd is het stemrecht uit te oefenen. Onder deze omstandigheid acht ik het zeer wel verdedigbaar dat de

460 In Rechtspersonen, M.J.G.C. Raaijmakers, aantekening 4 bij art. 336, p. 336-8 wordt het voorbeeld genoemd warin een vordering tot uitsluiting kan worden ingesteld tegen de concurrerende aandeelhouder die stelselmatig gebruik maakt van kennis de hij als aandeelhouder heeft verworven.

461 Zie omtrent deze problematiek § II.7 e.v. 
aandeelhouder slechts met toestemming van de pandhouder een vordering tot uittreding kan instellen.

Bij de procedure tot uittreding dient men mijns inziens rekening te houden met het volgende. Wie zal er geïnteresseerd zijn in het overnemen van aandelen die met een pandrecht zijn bezwaard? Dit probleem is nog nijpender indien het stemrecht verbonden aan de verpande aandelen bij de pandhouder berust.

\section{c. De positie van de pandhouder in geval van een gedwongen stemrecht over- gang}

Bij verpanding van aandelen geldt met betrekking tot de uitoefening het stemrecht verbonden aan de verpande aandelen de hoofdregel dat dit stemrecht wordt uitgeoefend door de aandeelhouder. De statuten van de vennootschap kunnen echter toestaan dat in de pandakte wordt bepaald dat niet de aandeelhouder bevoegd is tot het uitoefenen van het stemrecht, maar dat deze bevoegdheid toekomt aan de pandhouder. Doordat ook de stemgerechtigde pandhouder door zijn gedragingen het belang van de vennootschap kan schaden, diende de geschillenregeling een bepaling te bevatten waarin werd voorzien in de mogelijkheid dat de aandeelhouders van de zich misdragende pandhouder konden vorderen dat hij het hem toekomende stemrecht zou overdragen aan de pandgever/bloot-eigenaar van het aandeel. De vordering tot overgang van het stemrecht kan zowel door de bloot-eigenaar van de aandelen (de pandgever) als door een of meer 'overige' aandeelhouders worden ingesteld. In zijn relatie tot de pandgever kan de pandhouder bedingen dat de eerst genoemde van zijn rechten uit art. $342 \mathrm{BW}$ afstand zal doen. Is dit laatste het geval dan kan de vordering alleen worden ingesteld door een of meer houders van aandelen die alleen of tezamen ten minste een derde van het geplaatste kapitaal verschaffen. De pandhouder die wordt geconfronteerd met een vordering als hier bedoeld verliest, na toewijzing van de vordering, zijn stemrecht. Het stemrecht gaat van rechtswege over op het moment dat het vonnis in kracht van gewijsde gaat. Er vindt, anders dan bij de uitstoot- en uittredingsprocedure, geen prijsvaststelling plaats. In de $\mathrm{MvT}^{462}$ lezen wij hieromtrent:

\footnotetext{
"In het derde lid (curs. origineel) is bepaald dat de overgang van het stemrecht van rechtswege plaatsvindt door het in kracht van gewijsde gaan van het vonnis. Dit is mogelijk omdat voor de overgang van het stemrecht geen prijsvaststelling plaatsvindt. Bepaling van de waarde van het stemrecht, zo die er is, is immers buitengewoon moeilijk, zo niet onmogeiijk. Wel zal de overgang van het stemrecht in het aandeelhoudersregister moeten worden aangetekend. "
}

462 J.M.M. Maeijer, Wetsgeschiedenis, IXy-Art. 342-1. 
Schaadt een pandhouder door zijn gedragingen het belang van de vennootschap, men denke hierbij aan de wijze van uitoefening van het stemrecht waardoor bijvoorbeeld de besluitvorming binnen de vennootschap wordt gefrustreerd, dan kan hij onder omstandigheden worden gedwongen zijn stemrecht over te dragen aan de aandeelhouder/pandgever. Hierdoor verliest hij evenwel niet zijn bedongen zekerheid, het pandrecht blijft rusten op de aandelen. Wat hij wel verliest is de extra waarborg die hem de mogelijkheid bood de waarde van zijn pand te bewaken.

Aan het einde van deze paragraaf acht ik de conclusie gerechtvaardigd dat de wetgever bij het ontwerpen van de geschillenregeling, afgezien van de gedwongen stemrechtovergang, geen rekening heeft gehouden met de positie van de pandhouder. Wij zagen dat actie op grond van de geschillenregeling alleen kan worden ingesteld door de aandeelhouder(s), niet door de pandhouder, zelfs niet wanneer hem het stemrecht is toegekend. Zoals eerder opgemerkt staat bij de geschillenregeling, in tegenstelling tot de uitkoopregeling waar het gaat om de zeggenschap, de kapitaalverschaffing op de voorgrond. In de praktijk zullen pandhouder en aandeelhouder/pandgever problemen, die gepaard gaan met de toepassing van de geschillenregeling, onderling trachten op te lossen. Denkbaar is tevens dat problemen betrekkelijk de geschillenregeling voorkomen kunnen worden door voorzieningen in de pandakte op te nemen. Echter, is het niet redelijker om, in het kader van de geschillenregeling, de pandhouder dezelfde rechten toe te kennen als de aandeelhouder? 



\section{Samenvatting}

Dit boek bestaat uit twee delen.

In het eerste deel wordt uitgebreid aandacht besteed aan de algemene aspecten van verpanding van aandelen. Zowel de goederenrechtelijke als de vennootschapsrechtelijke zijde van het fenomeen wordt belicht.

Sedert de inwerkingtreding van de Wet vruchtgebruik en pandrecht op aandelen in 1976 beschikt het Nederlandse rechtspersonenrecht over een lex specialis met betrekking tot de verpanding van aandelen op naam in naamloze en besloten vennootschappen. Na kort te zijn ingegaan op de totstandkoming van deze wet wordt achtereenvolgens aandacht besteed aan de wettelijke regeling en de mogelijkheid van verpanding van aandelen in naamloze en besloten vennootschappen. Kort wordt stilgestaan bij de inhoudelijke en tekstuele verschillen tussen de artt. 89 en 198 BW. Vervolgens wordt de regeling van de inpandneming van eigen aandelen kritisch bezien.

$\mathrm{Na}$ deze min of meer historische en theoretische beschouwingen volgt een technische benadering van de wijze van vestiging van een recht van pand op aandelen aan toonder en op naamaandelen. Hierbij wordt stilgestaan bij de gevolgen van de in 1993 in werking getreden nieuwe regeling voor de overdracht van aandelen op naam in NV's en BV's voor de - wijze van - vestiging van een recht van pand op dergelijke aandelen. Zo wordt in dit kader onder andere aandacht besteed aan - de mogelijkheid van - het vestigen van een stil pandrecht op aandelen in een besloten vennootschap en in een al dan niet ter beurze genoteerde naamloze vennootschap.

$\mathrm{Na}$ de perikelen met betrekking tot de vestiging van het pandrecht te hebben besproken passeert de overgang van het stemrecht verbonden aan de verpande aandelen de revue. Hoofdregel is dat het stemrecht in beginsel bij de aandeelhouder/pandgever blijft. Echter, van dit principe kan, binnen de wettelijke en statutaire grenzen, worden afgeweken.

In het middenstuk van het eerste deel van dit boek staat een aantal rechten centraal. In de eerste plaats zijn dat de vennootschapsrechtelijke bevoegdheden van de aandeelhouder en de pandhouder, enerzijds in relatie tot elkander en anderzijds in relatie tot de vennootschap. In de tweede plaats wordt aandacht besteed aan een aantal goederenrechtelijke rechten en plichten van de pandhouder. Het recht tot terughouding van het aandeel en de zorgplicht van de pandhouder ten aanzien van het pand zijn slechts enkele van de besproken rechten en plichten. In de derde plaats staat de verhouding tussen de pandhouder en de vennootschap centraal. 
In een drietal situaties wordt deze relatie beschreven; te weten het geval waarin de pandhouder stemrecht kan uitoefenen in de algemene vergadering van aandeelhouders, het geval waarin hem deze bevoegdheid niet toekomt en het geval waarin de pandhouder een beroep doet c.q. kan doen op de artt. 8 en 15 BW.

$\mathrm{Na}$ de beschrijving van de rechten en plichten van de aandeelhouder/pandgever en pandhouder wordt ingegaan op een bijzonder soort pandrecht, namelijk het wettelijk pandrecht van certificaathouders, geregeld in art. 3:259 BW. Alvorens dit bijzondere pandrecht te bespreken, het af te zetten tegen een 'gewoon' pandrecht ten behoeve van certificaathouders en de gevolgen van het wettelijk pandrecht voor bijvoorbeeld het ontstaan van lidmaatschapsrechten in kaart te brengen, zal kort worden ingegaan op de certificering van aandelen in het algemeen en wordt een antwoord gegeven op de vraag wanneer gesproken kan worden over een bewilligde certificering van aandelen.

In de voorlaatste paragraaf van het eerste deel van dit boek wordt de regeling van beslag op en executie van aandelen door de pandhouder besproken.

Het eerste deel wordt afgesloten met enkele beschouwingen ten aanzien van het einde van het pandrecht.

In het tweede - bijzondere - deel van dit boek staat een drietal vennootschapsrechtelijke thema's centraal.

Het eerste onderwerp wordt gevormd door de relatie tussen de verpanding van aandelen en de beslotenheid van de vennootschap. Om uiteindelijke de vraag te beantwoorden of verpanding van aandelen kan leiden tot doorbraak van de beslotenheid van samenwerkingsverbanden wordt kort ingegaan op de rijke historie van de kapitaalvennootschappen naar Nederlands recht.

Aangegeven wordt dat, met inachtneming van de grenzen getrokken door wet en statuten, een aantal verschijningsvormen van naamloze en besloten vennootschappen kan worden onderscheiden. Centraal staat hierbij de door de wetgever imperatief voorgeschreven blokkering van aandelen in het kapitaal van de besloten vennootschap ex art. $195 \mathrm{BW}$. Deze verplichte blokkering wordt aan een kritische beschouwing onderworpen. Na deze exercitie wordt ingegaan op de vraag of verpanding van aandelen kan leiden tot doorbraak van het besloten karakter van kapitaalvennootschappen. Hiertoe wordt een aantal situaties onder de loupe genomen. Allereerst wordt bezien of bij de open naamloze vennootschap gevreesd moet worden voor doorbraak van beslotenheid ten gevolge van verpanding van aandelen. Gesteld wordt dat deze vrees niet gerechtvaardigd is. Vervolgens worden de gevolgen van verpanding van aandelen besproken voor de internbesloten vennootschap. In dit geval kan er gesproken worden van een doorbraak van de beslotenheid. In gelijke zin wordt geconcludeerd ten aanzien van de gevolgen van verpanding van aandelen in de besloten en de gemengde naamloze vennootschap. $\mathrm{Na}$ de beschrijving van deze drie situaties wordt vervolgens aandacht besteed aan de gevolgen van het vestigen van een stil pandrecht voor de 
beslotenheid van a. de open naamloze vennootschap, b. de intern-besloten vennootschap en $\mathrm{c}$. de gemengde vennootschap.

Het tweede bijzondere thema in dit deel van het boek wordt gevormd door de relatie tussen verpanding van aandelen en de juridische fusie van titel 7 van Boek $2 \mathrm{BW}$. Na een korte beschrijving van de regeling van uitkoop van kleine minderheidsbelangen in kapitaalvennootschappen en de geschillenregeling van titel 8, afdeling 1 van Boek $2 \mathrm{BW}$, wordt stil gestaan bij de rechtspositie van de verschillende actoren.

De relatie tussen de verpanding van aandelen en de uitkoop- en de geschillenregeling vormt het derde en laatste thema van het tweede deel van dit boek. De vraag of de houder van een pandrecht op aandelen in de verdwijnende vennootschap een pandrecht verkrijgt op de aandelen in de verkrijgende vennootschap komt aan de orde, alsmede de vraag naar wat rechtens is indien de houder van een pandrecht op aandelen in de verdwijnende vennootschap gerechtigd is het stemrecht op deze aandelen uit te oefenen en de statuten van de verkrijgende vennootschap een dergelijke stemrechtovergang uitdrukkelijk uitsluiten.

Het onderzoek werd afgesloten in januari 1996. 


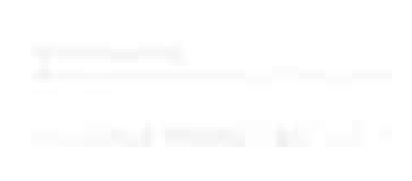




\section{SUMMARY}

This book consist of two parts. In the first part, the author pays attention to general aspects of pledging shares; both property-law and company-law aspects of this phenomenon are discussed.

Since the Act governing usufruct and pledging of shares (Wet vruchtgebruik en pandrecht op aandelen) came into effect in 1976, Dutch company law has a lex specialis relating to the pledging of registered shares in Dutch limited liability companies (naamloze en besloten vennootschappen [NVs and BVs]. After a brief discussion of its history, the Act itself and the possibility of pledging shares of Dutch companies is treated. The substantive and textual differences of articles 2:89 and 2:198 of the Dutch Civil Code (BW) are briefly dwelled upon. This is followed by a critical comment on the rule governing the company's becoming the pledgee of its own shares.

After this historical and theoretical account, the author looks at the manner in which pledges can be vested on bearer shares and registered shares from a more technical angle. In particular, the effects of the 1993 rules governing the transfer of registered shares in Dutch NVs and BVs, on establishing an undisclosed pledge (stil pandrecht) on shares of Dutch closed limited liability companies (BVs) and of listed and unlisted Dutch public limited liability companies (NVs).

After a discussion of the vesting of a right of pledge in shares, the author goes on to deal with the transfer of the voting rights attached to the shares pledged. The principal rule is that the voting right remains with the shareholder/pledgor. However, there are exceptions to this principle imposed by law and the company's statutes.

The middle section of the first part of the book focuses on a number of rights. First, there are the powers of the shareholder and the pledgee, both in relation to each other and in relation to the company. Subsequently, some of the pledgee's possessory rights and obligations are discussed, such as his power to retain the share and the duty of care imposed upon him. Third, the relation between the pledgee and the company is treated. This relation is discussed in the light of three different situations: the situation in which the pledgee has a right to vote at the general shareholders' meeting, that in which he is not so entitled and the case in which the pledgee invokes or, as the case may be, may invoke articles $2: 8$ and 2:15 BW.

After treating the rights and duties of the shareholder/pledgor and those of the pledgee, the author focuses his attention on a special right of pledge for holders of depository receipts, as laid down in article 3:359 BW. Treatment of this special right of pledge, a comparison with the 'ordinary' right of pledge for 
holders of depository receipts and a listing of the effects of this special statutory right of pledge on, for instance, the creation of 'membership rights' (lidmaatschapsrechten), are preceded by a discussion of the depositing of shares in general and by providing an answer to the question as to when there is a case of company cooperation in the depositing of shares.

In the penultimate section of the first part, the rules governing the pledgee's possibility of attachment and execution are treated.

Some observations on the extinction of the right of pledge conclude part one.

In the second, more specific part, the author discusses three company-law topics. The first topic is the relation between pledging shares and the closed character of a company. The rich history of Dutch share companies is looked into in order to find an answer to the question of whether pledging shares pierces the closed character of incorporated associations.

The author indicates that, within the confines drawn by law and the company's statutes, various types of Dutch public limited liability companies (NVs) and closed limited liability companies (BVs) can be distinguished. Key factor here is the mandatory restriction of the transfer of shares (blokkering) in the capital of a closed limited liability company (BV) prescribed in article 2:195 BW, which is subjected to scrutiny. This is followed by a treatment of the question of whether pledging shares leads to a piercing of the closed character of share companies. A number of situations are studied. First, the risk of piercing the closed character of open public limited liability companies (NVs) through the pledging of shares is examined. The author claims that this is not so. Subsequently, the effects of pledging shares on closed limited liability companies (BVs) are discussed. In these cases, a piercing of the closed character does occur. A similar conclusion is drawn for the effect of pledging shares in public liability companies with a closed character and those with a semi-open character. This discussion is followed by a treatment of the effects on the closed character of a. open public limited liability companies, b. closed limited liability companies (BVs) and c. semi-open public limited liability companies, when an undisclosed pledge is vested.

The relation between pledging shares and the rules on merger (juridische fusie) laid down in Title 7 of Book $2 \mathrm{BW}$, is the second special topic of this part of the book. The author goes into two questions (i) will a person vested with a right of pledge in the shares of a company ceasing to exist, acquire a right of pledge in the shares of the acquiring company and (ii) which rules apply to the case in which a person vested with a right of pledge in shares of the company ceasing to exist, is entitled to vote and the statutes of the acquiring company prohibit the transfer of such voting rights. 
The third and final theme of the second part of the book is the relation between pledging shares and the rules on buying out minority shareholders and between pledging shares and the rules on dispute resolution. Following a brief description of the rules governing the buying-out of small minority interests in share companies and the statutory rules on the resolution of disputes as laid down in Title 8, Chapter 1 of Book $2 \mathrm{BW}$, the legal position of the various actors is studied.

This study was concluded in January 1996. 



\section{Lijst van geraadpleegde en verkort aangehaalde literatuur}

Asser-Beekhuis Zakenrecht

Asser-Hartkamp II

Asser-Maeijer-2-III

Asser-Mijnssen Zakenrecht III

\section{Asser-van der Grinten I}

Belinfante 1929

Blokland, $\mathrm{T}$.

Olffen, M. van

Brahn, O.K.

Brenninkmeijer, A.M.

Burgerlijke Rechtsvordering
Mr. C. Asser's handleiding tot beoefening van het Nederlands burgerlijk recht. Zakenrecht, tweede deel, Eigendom en beperkte zakelijke genotsrechten, bewerkt door J.H. Beekhuis, W.J.M. Davids, F.H.J. Mijnssen, A.A. van Velten, W.E.J. Tjeenk Willink, Zwolle, $12^{\circ}$ druk, 1990.

Mr. C. Asser's handleiding tot beoefening van het Nederlands burgerlijk recht. Verbintenissenrecht, Deel II, algemene leer der overeenkomsten, bewerkt door mr. A.S. Hartkamp. Tjeenk Willink, Zwolle, $8^{e}$ druk, 1989.

Mr. C. Asser's handleiding tot beoefening van het Nedertands burgerlijk recht. Vertegenwoordiging en rechtspersoon. De naamloze en besloten vennootschap, bewerkt door J.M.M. Maeijer, met medewerking van P.J. Dortmond, W.E.J. Tjeenk Willink, Zwolle, $I^{\circ}$ druk, 1994.

Mr. C. Asser's handleiding tot beoefening van het Nederlands burgerlijk recht. Zakenrecht. Zekerheidsrechten, bewerkt door F.H.J. Mijnssen, W.E.J. Tjeenk Willink, Zwolle, $12^{\star}$ druk, 1994.

Mr. C. Asser's handleiding tot beoefening van het Nederlands burgerlijk recht. De vertegenwoordiging, bewerkt door prof. mr. W.C.L. van der Grinten, Tjeenk Willink, Zwolle, $7^{\star}$ druk, 1990.

Ontwerpen van wetten op de vennootschappen en andere wijziging en aanvulling van de bepalingen omtrent de Naamlooze Vennootschap en regeling van de aansprakelijkheid voor het prospectus, 1929, Gebr. Belinfante (N.V.), 's-Gravenhage.

Uitgifte, verkoop en levering van (beperkte rechten op) aandelen op naam, Law \& Practice Publishers, Deventer, 1992.

Vruchtgebruik en pandrecht op aandelen volgens Bock 2 NBW, TVVS 1975, p. 195 e.v.

Stemovereenkomsten van aandeelhouders: de gebondenheid aan stemovereenkomsten, tegen de achtergrond van het Franse en Duitse vennootschapsrecht, diss. Serie Monografieēn vanwege het Van der Heijden-instituut-8, Kluwer, Deventer, 1973.

Burgerlijke Rechtsvordering (losbladig), red. W.D.H. Asser e.a., Kluwer, Deventer. 
Buijn, F.K.

Buijn, F.K.

Carz, E.W.

Cleveringa, R.P.

Coebergh, H.P.J.M.

Cremers, J.H.F.J.

Dijk, M.C.M. van

Dortmond, P.J.

Raaijmakers, M.J.G.C.

Dortmond, P.J.

Dortmond, P.J.

Dumoulin, S.H.M.A.

Eisma, S.E.

Eisma, S.E.

Eisma, S.E.

Uniken Venema, C.E.

Goudsmit, J.J.

Grinten, W.C.L. van der
De oprichting van de NV en de BV, diss. Serie Monografieën vanwege het Van der Heijden-instituut-24, Kluwer, Deventer, 1983.

De overdracht van aandelen op naam; de prakrijk, WPNR 5966 (1990), p. 412 e.v.

Beslag op aandeelen, NV 19 (1941), p. 298 e.v.

Beslag op aandelen, NV 30 (1953), p. 202 e.v.

Vruchtgebruik en pandrecht op - en levering van aandelen, NV 52 (1974), p. 75 e.v.

Prioriteitsaandelen. diss. Serie Monografieën vanwege het Van der Heijden-instituut-5, Kluwer, Deventer, 1971.

Reactie op "WTE van toepassing bij executoriale verkoop van aandelen", V\&O 1995, p. 9 e.v.

De Juridische fusie naar wordend recht, Preadviezen uitgebracht voor de Vereeniging 'Handelsrecht', W.E.J. Tjeenk Willink, Zwolle, 1980 .

Het advies van de Commissie Vennootschapsrecht inzake overdracht van aandelen, NV 65 (1987), p. 49 e.v.

Enige beschouwingen rondom aandelen, diss. Serie Monografieën vanwege het Van der Heijden-instituut-31, Kluwer, Deventer, 1989.

Het legitimatieprobleem bij overdracht van aandelen op naam, TVVS 1994, p. 29 e.v.

Verkrijging van aandelen op naam na invoering van het Derde Misbruikontwerp, WPNR 5763 (1985), p. 773 e.v.

Opnieuw: Verkrijging van aandelen op naam, WPNR 5932 (1989), p. 573 e.v.

Eigendom ten titel van beheer naar komend recht, Preadvies van de Vereeniging 'Handelsrecht', W.E.J. Tjeenk Willink, Zwolle, 1990.

Een hiaat in de blokkeringsregeling van de B.V., TVVS 1978, p. 11 e.v.

Is het wenselijk voor de zogenaamde besloten naamloze vennootschap in de civielrechtelijke wetgeving bijzondere voorzieningen te treffen, al dan niet met invoering van een afzonderlijke rechtsvorm?, Handelingen der Nederlandse Juristen Vereniging, Deel I, Zwolle, 1953. 
Grinten, W.C.L. van der

Grinten, W.C.L. van der

Grinten, W.C.L. van der

Grundmann, C.M.

Grundmann-Van de Krol, C.M. Vonmvoorschriften afstand pandrecht op aandelen op naam, WPNR

6139 (1994), p. 404 e.v.

Hamers, J.J.A.

Hamers, J.J.A.

Handboek (1989)

Handboek (1992)

Hendriks-Jansen, Th.C.M.

Heemskerk, W.H.

Heijden, E.J.J. van der

Heijden, E.J.J. van der

Hellema, H.J.

Henriquez, E.C.

Hoek, P.C. van den

Honée, H.J.M.N.

Honée, H.J.M.N.

Overdracht van aandelen op naam, WPNR 5966 (1990), p. 410 e.v.

Levering van aandelen op naam, NV 70 (1992), p. 25.

Overdracht van aandelen op naam, WPNR 5966 (1990), p. 410 e.v.

Notariële akte vereist voor levering van aandelen op naan, Bb 1992, p. 190 e.v.

Nieuwe regeling van overdracht van aandelen op naam en de vestiging van pandrecht daarop, De Notarisklerk, 1993, p. 25 e.v.

Levering van aandelen op naam, in: Dossier Ondememingsrecht '96, nr. 22 1995, p. 12 e.v.

E.J.J. van der Heijden, Handboek voor de naamloze en besloten vennootschap, $11^{\mathrm{c}}$ druk, bewerkt door W.C.L. van der Grinten, W.E.J. Tjeenk Willink, Zwolle, 1989.

E.J.J. van der Heijden, Handboek voor de naamloze en besloten vennootschap, $12^{\circ}$ druk, bewerkt door W.C.L. van der Grinten, W.E.J. Tjeenk Willink, Zwolle, 1992.

Vennootschapswetgeving 21155 - Wijziging van de regeling van de overdracht van aandelen op naam in naamloze en besloten vennootschappen met beperkte aansprakelijkheid, NV 70 (1992), p. 63.

Het nieuwe executie- en beslagrecht, 3* (herz.) druk, Lemma, Utrecht, 1992.

De ontwikkeling van de naamlooze vennootschap in Nederland voor de codificatie, diss. Martinus Nijhoff, 's-Gravenhage, 1908.

Beslag op aandeelen, NV 12 (1934), p. 321 e.v.

De beperkte publikatieplicht van de BV, NV 48 (1970/1971), p. 72 e.v.

Beslag op aandelen op naam, TVVS 1973, p. 267 e.v.

De uitkoopregeling van aandelen, Account Dossier Ondernemingsrecht, nr. 1 1990/91, p. 43 e.v.

Het gewijzigde ontwerp aanpassingswet tweede EEG-Richtlijn (slot), NV 58 (1980), p. 138.

De notaris als vennootschappelijk huismeester, NV 68 (1990), p. 93 e.v. 
Houwen, L.G.H.J.

Hugenholtz, W. Heemskerk, W.H.

Huigen, W.G.

Hulle, K. van

Huume, G.M. ter

Huurne, G.M. ter

Huurne, G.M. ter

Ingh, F.J.P. van den

Ingh, F.J.P. van den

Ingh, F.J.P van den

Jansen, F.M.J.

Jansen, F.M.J.

Kluiver, H.J. de

Kluiver, H.J. de

Gerven, W. van (eds.)

Kluiver, H.J. de
De wettelijke regeling tot uitkoop van minderheidsaandeelhouders, NV 66 (1988), p. 17 e.v.

Hoofdlijnen van het Nederlands burgerlijk procesrecbt, $17^{\mathbf{e}}$ druk, Uitgeverij Lemma, Utrecht, 1994.

Vestiging van pandrecht op aandelen in het Nieuw BW, JBN 1991, p. 7 e.v.

De Harmonisatie van het vennootschapsrecht in de Europese Gemeenschap, in: Harmonisatie van Vennootschaps- en Effectenrecht; Ervaringen en vooruitzichten in Europa en de Verenigde Staten, Deventer, 1988, p. 35 e.v.

Relativiteit en levering van aandelen op naam in rechtsvergelijkend perspectief, TVVS 1991, p. 314 e.v.

Nieuwe regels voor de levering van aandelen op naam, diss. Uitgave vanwege het Instituut voor Ondernemingsrecht Rijksuniversiteit Groningen-20, Kluwer, Deventer 1994.

Notariele akte en aandeelhoudersregister bij emissie en levering van aandelen op naam, NV 73 (1995), p. 119.

De medewerkingseis van art. 3.9.3.1. INBW, (I), WPNR 5943 (1989), p. 627 e.v.

Certificering en certificaat van aandeel bij de besloten vennootschap, diss. Serie Monografieẽn vanwege het Van der Heijden-instituut-35, Kluwer, Deventer, 1991.

Reactie op C.A. Schwarz, Enkele vragen bij certificering van aandelen, TVVS 1992, p. 6 e.v., TVVS 1992, p. 77 e.v.

Gerechtelijke executies van effecten, WPNR 4841 (1965), p. 1.

Executie- en beslagrecht, $4^{e}$ druk, W.E.J. Tjeenk Willink, Zwolle 1990.

Joint ventures en stemovereenkomsten. Een rechtsvergelijkend perspectief, in: 'Joint Ventures', A.Ae 44 (1995) 5, p. 432/104 e.v.

The European Private Company? Maklu Uitgevers, AntwerpenApeldoom, 1995.

The European Private Company? A Dutch Perspective, in: 'The European Private Company?' eds. H.J. de Kluiver, W. van Gerven, Maklu Uitgevers, Antwerpen-Apeldoom, 1995, p. 109 e.v. 
Kupperman, M

Garderen, E.J. van

Maeijer, J.M.M.

Maeijer, J.M.M.

Maeijer J.M.M., Schreurs J.A.W.

Maeijer, J.M.M.

Maschhaupt, J.H. Storm, P.M.

Maschhaupt, J.H Storm, P.M.

Meijers, E.M.

Meilink, J.G.

Mijnssen, F.H.J.

Mijnssen, F.H.J.

Mohr, A.L.

Molenaar, F.

Molenaar, F.
Notariële aandelen-levering en -uitgifte een enquête, NV 73 (1995), p. 114 (Met naschrift van D.F.M.N. Zaman).

De stemovereenkomst van aandeelhouders, in: 'Recht zo die gaat' (P.W. van der Ploeg-bundel), W.E.J. Tjeenk Willink, Zwolle 1976, p. 95 e.v.

Naar een eigen rechtsvorm voor de besloten vennootschap, NV 46 (1968), p. 25 e.v.

Parlementaire Geschiedenis Rechtspersonen- en vennootschapsrecht in verband met de invoering van de boeken 3,5 en 6 NBW op 1 januari 1992, Samson HD Tjeenk Willink, Alphen aan de Rijn, 1991.

Wetsgeschiedenis. Naamloze en besloten vennootschap, Losbladig, Samson HD Tjeenk Willink, Alphen aan de Rijn.

De Tweede EEG-Richtlijn inzake vennootschapsrecht, preadviezen uitgebracht voor de gezamenlijke vergadering op 8 december 1978 van de Vereeniging 'Handelsrecht' en de Nederlandse Vereniging voor Europees recht, W.E.J. Tjeenk Willink, Zwolle, 1978.

Aanpassingswet Tweede Richtlijn door Tweede Kamer (II), TVVS 1981 , p. 77 e.v.

Ontwerp voor een Nieuw Burgerlijk Wetboek, Tekst Eerste Gedeelte 1-4, Staatsdrukkerij en uitgeverijbedrijf/'s-Gravenhage, 1954.

Over verpanding, in het bijzonder van aandeelen op naam in een Naamloze Vennootschap, diss. Eduard Udo, Leiden, 1898.

De positie van de pandhouder van toonderaandelen in een NV na omzetting daarvan in een BV, NJB 1973, p. 153 e.v.

Bezitloos en stil pandrecht in het NBW, Advocatenblad 1981, p. 385 e.v.

Spijkers. Ondernemingsrecht op de breuklijn van praktijk en wetenschap, rede, Gouda Quint, Amhem, 1993.

Pandrecht, Mon. Nieuw BW, B12a, $2^{\circ}$ druk, Kluwer, Deventer, 1991.

Algemene Bepalingen zekerheidsrechten op goederen, Mon. Nieuw BW 11 B-Serie, Kluwer, Deventer, 1992. 
Mourik, M.J.A. van

Mourik, M.J.A. van

Nederlands Genootschap van bedrijfsjuristen

Nolet, J.V.

Olffen, M. van

Olffen, M. van

Olffen, M. van

Olffen, M. van

Olffen, M. van

Olffen, M. van

Olffen, M. van

Zaman, D.F.M.N.

Olffen, M. van

Ophof, H.P.J.

Ophof, H.P.J.

Perrick, S.
Nogmaals over aandeelhouderschap en huwelijksgemeenschap, NV 62 (1984), p. 200 e.v.

Verwikkelingen rond aandelen, WPNR 5877 (1988), p. 323 e.v.

Advies van het Nederiands Genootschap van Bedrijfsjuristen inzake het wetsvoorstel Wijziging van de regel van de overdracht van aandelen op naam, De naamloze vennootschap 67/9, september 1989.

Vruchtgebruik en pandrecht op aandelen, WPNR 5352 (1976), p. 3 67.

Levering aandelen op naam, Bank- en Effectenbedrijf, 1988, p. 273 e.v.

Overdracht van aandelen op naam in overige EG-Lidstaten, alsmede Oostenrijk, Turkije en Zwitserland, WPNR 5966 (1990), p. 417 e.y.

Uitgifte en overdracbt van aandelen op naam, amendementen aanvaard, JBN 1992, p. 6 e.v.

Bezitloos pandrecht op aandelen op naam, V\&O 1992 p. 71 e.v.

Uitgifte en levering van (beperkte rechten op) aandelen op naam, WPNR 6073 (1992), p. 920 e.v.

Ontstaan en eindigen van een pandrecht op aandelen op naam, WPNR 6107 (1993), p. 692 e.v.

Nieuwe bepalingen omtrent uitgifte en levering van aandelen op naam, Preadvies van de Vereeniging 'Handelsrecht', W.E.J. Tjeenk Willink, Zwolle, 1994.

Constateren van en werken met een gebrekkige uitgifte en levering van aandelen op naam, NV 73 (1995), 123.

Overdracht van aandelen op naam, TVVS 1991, p. 277 e.v.

Dient art. 2:98c/207c BW te worden gewijzigd c.q. geschrapt? in: 'Knelpunten in de vennootschapswetgeving'. Uitgave vanwege het Institurut voor Ondernemingsrecht Rijksuniversiteit Groningen-24, Kluwer, Deventer, 1995

De aandelen in een NV of BV en de langstlevende echtgenoot als vruchtgebruiker volgens het wetsontwerp tot wijziging van Boek 4 Nieuw Burgerlijk Wetboek, NV 60 (1982), p. 140 e.v. 
Pitlo/Lőwensteyn

Pitlo/Reehuis, Heisterkamp

Raaijmakers, M.J.G.C.

Dortmond, P.J.

Raaijmakers, M.J.G.C.

Rechtspersonen

Reehuis, W.H.M.

Reehuis, W.H.M.

Sanders, $\mathbf{P}$.

Schellekens, W.A.M.

Schilfgaande, P. van

Schilfgaarde, P. van

Schilfgaarde, P. van

Schwarz, C.A.

Schwarz, C.A.

Schwarz, C.A.

Schwarz, C.A.

Schwarz, C.A.
Pitlo. Het Nederlandse burgerlijke recht Deel 2 Rechtspersonenrecht, F.J.W. Lôwensteyn, M.J.G.C. Raaijmakers, Gouda Quint, Amhem, $3^{\circ}$ dnuk, 1994.

Pitlo. Het Nederlandse burgerlijke recht Deel 3 Goederenrecht, $10^{\circ}$ geheel herschreven druk, W.H.M. Reehuis, A.H.T. Heisterkamp. G.E. van Maanen, G.T. de Jong, Gouda Quint, Amhem, 1994.

De Juridische fusie naar wordend recht, Preadviezen uitgebracht voor de Vereeniging 'Handelsrecht', W.E.J. Tjeenk Willink, Zwolle, 1980.

Besluit van aandeelhouders tot statutenwijziging in strijd met de redelijkheid en billijkheid, AAe 40 (1991), p. 1009 e.v.

Rechtspersonen (losbladig), red. C.A. Boukema e.a. Kluwer, Deventer.

Stille verpanding van roerende zaken en vorderingen volgens het NBW, diss, Gouda Quint, Arnhem, 1987.

Voorrang en zekerheidsrechten in het nieuwe BW, Kwartaalbericht Nieuw BW 1991, p. 1 e.v.

Open en besloten N.V., NV 43 (1965), p. 53 e.v.

WTE van toepassing bij executoriale verkoop van aandelen, V\&O 1994 , p. 111 e.v.

Recente rechtspraak, WPNR 5911 (1989), p. 212.

Van de BV en de NV, naar het recht van 1992, $8^{\circ}$ druk, Gouda Quint BV, Amhem, 1990.

Van de BV en de NV, $10^{\circ}$ druk, Gouda Quint BV, Amhem, 1995.

Overdracht van aandeelhouderschap en art. 195 Boek 2 BW, NV 61 (1983), p. 223 e.v.

Blokkering van aandelen, diss. Serie Monografieën vanwege het Van der Heijden-instituut-27, Kluwer, Deventer, 1986.

Aandelen zonder stemrecht, rede, W.E.J. Tjeenk Willink, Zwolle 1990.

Enkele vragen bij certificering van aandelen, TVVS 1992, p. 6 e.v.

Versterking van het beschermend effect van certificering van aandelen, WPNR 6104 (1993), p. 617 e.v. 
Schwarz, C.A.

Schwar, C.A.

Schwarz, C.A.

Schwarz, C.A.

Loos, E.J.R.

Sikkelerus, W.P.

Sint Truiden, M. Ph. van

Slagter, W.J.

Slagter, W.J.

Slagter, W.J.

Slagter, W.J

Slagter, W.J.

Slagter, W.J.

Slagter, W.J.

Slagter, W.J.

Snijders, W.
'Ach, eindeloos getob', Over toelating van de echtgenoot van de aandeelhouder tot het stemrecht op aandelen, NJB 1994, p. 1068 e.v.

De invloed van vergadergerechtigden zonder stemrecht op besluitvorming in de aandeelhoudersvergadering, in: 'Heden verschenen voor mij...' (Liber Amicorum A.L.M. Soons), red. P.H.M. Gerver, J.G. Kuijl, A.J.H. Pleysier, R.T.G. Verstraaten, Amhem, 1995, p. 201 e.v.

"Private" as in Private Companies, in: "The European Private Company?' eds. H.J. de Kuiver. W. van Gerven, Maklu Uitgevers Antwerpen-Apeldoom, 1995, p. 221 e.v.

Artikel 12 van de SER-Fusiecode, mede in het licht van de opvolging van een openbaar bod door een juridische fusie of geschillenprocedure, verschenen in NJB mei 1996.

Misbruik van rechtspersonen (overdracht van aandelen), M.B.B. 1987, p. 117 e.v.

Nieuwe regeling van overdracht van aandelen op naam en de vestiging van een pandrecht daarop per 1 januari 1993, NTBR 1993, p. 29 e.v.

Wetsontwerp betreffende uitkoop van minderheidsaandeelhouders, TVVS 1985, pag. 128 e.v.

Levering van aandelen op naam en het derde misbruik-voorstel, TVVS 1986 , p. 13 e.v.

Levering van aandelen op naam, NV 67 (1989), p. 196 e.v.

Boekbespreking: A. van Oven en F.J.W. Löwensteyn, Handelsrecht. Algemene inleiding en ondernemingsrecht, $2^{\circ}$ druk, W.E.J. Tjeenk Willink, Zwolle, 1989, in: TVVS 1990, p. 50 e.v.

Uitkoopregeling, TVVS 1990 , p. 232

Levering van aandelen op naam, WPNR 5966 (1990), p. 415 e.v.

Levering van aandelen op naam, TVVS 1992, p. 94 e.v.

Compendium van het ondernemingsrecht, $6^{\mathrm{e}}$ druk, Kluwer-Deventer, 1993.

in: Verslag Eigendom ten titel van beheer naar komend recht, Preadvies van de Vereeniging 'Handelsrecht' W.E.J. Tjeenk Willink, Zwolle, 1990. 
Snijders, H.J.

Rank-Berenschot, E.B.

Star Busmann, C.W.

Rutten, L.E.H.

Ariëns, W.H.A.

Steenbergen, S.M. van

Steenbergen, S.M. van

Steenderen, C.E.M. van

Brink, J.C.G. ten

Stein, P.A.

Steinvoort, H.J.

Storm, P.M.

Thielen, J.E.D.M.

Timmerman, L.

Timmerman, L.

Timmerman, $\mathrm{L}$.

Uniken Venema, C.Æ

Eisma, S.E.

Vermeend, W.

Vliet, M.J. van

Vlist, R. van der

Volmer, H.F.A.
Goederenrecht, Kluwer, Deventer 1994.

Hoofdstukken van burgerlijke rechtsvordening, $3^{e}$ druk, De Erven F. Bohn, Haarlem, 1972.

De levering van aandelen op naam, TVVS 1987, p. 93 e.v.

De mogelijkheid van uitkoop van kleine minderheidsbelangen in NV's en BV's, TVVS 1988 p. 143 e.v.

Uitgifte en levering van aandelen op naam, TVVS 1992, p. 303 e.v.

Compendium van het burgerlijk procesrecht, $10^{\circ}$ druk, Kluwer, Deventer, 1995.

Het congres 'Aandelen', TVVS 1988, p. 189 e.v.

Overdracht van aandelen op naam. Het klopt nog steeds niet, TVVS 1992, p. 95 e.v.

Levering van aandelen op naam, nu en straks, TVVS 1988, p. 33 e.v.

De beslotenheid nader beschouwd, TVVS 1975, p. 241 e.v.

Stemrecht op verpande aandelen, TVVS 1990, p. 202

Bespreking van de twaalfde druk van het Handboek voor de naamloze en de besloten vennootschap, bewerkt door Prof. mr W.C.L. van der Grinten, NV 72 (1994), p. 247 e.v.

Eigendom ten titel van beheer naar komend recht, Preadvies van de Vereeniging 'Handelsrecht', W.E.J. Tjeenk Willink, Zwolle, 1990.

Overdracht van aandelen op naam, WPNR 5966 (1990), p. 419 e.v.

Uitkoop van minderheidsaandeelhouders: een overzicht, NV 69 (1991), p. 30 e.v.

Uitkoop van kleine minderheidsbelangen in NV's en BV's, NV 63 (1985), p. 162 e.v.

Balanspublicatie van besloten- en familievennootschappen, NV 7 (1928), p. 131 e.v. 
Voogd, R.P.

Wachter, B.

Wessels, B.

Westbroek, W.

Westbroek, W.

Zaman, D.F.M.N.

Zeben, C.J. van

Du Pon, J.W. (I)

Zeben, C.J. van

Du Pon, J.W. (II)
Statutaire beschermingsmaatregelen bij beursvennootschappen, diss. Serie Monografieẽn vanwege het Van der Heijden-instituut-32, Kluwer, Deventer, 1989.

Blokkeringsclausules en stemrecht, in: 'Verzekeringen van Vriendsthap' (T.J. Dorhout Mees-bundel), Kluwer, Deventer, 1974, p. 231 e.v.

Levering van aandelen op naam: onduidelijk wetsvoorstel, NV 70 (1992), p. 86 e.v.

De nieuwste druk van het handboek, NV 55 (1977), p. 143 e.v.

Uitkoop en geschillenregeling, WPNR 5759 (1985), 709 e.v.

Misbruik + rechtszekerheid $=$ notariële aandelenoverdracht, $\mathrm{Bb}$ 1992, p. 45 e.v.

Parlementaire geschiedenis van het Nieuwe burgerlijke wetboek. Parlementaire stukken systematisch gerangschikt en van noten voorzien. C.J. van Zeben, J.W. Du Pon, M.M. Olthof, Boek 3 Vermogensrecht in het algemeen, Kluwer, Deventer, 1981.

Parlementaire geschiedenis van het Nieuwe burgerlijke wetboek. Parlementaire stukken systematisch gerangschikt en van noten voorzien. C.J. van Zeben, J.W. Du Pon, Invoering Boeken 3, 5 en 6, Boek 3, Vermogensrecht in het algemeen, W.H.M. Reehuis, E.E. Slob, Kluwer, Deventer, 1990 


\section{Trefwoordenregister}

A

Aanbiedingsblokkade

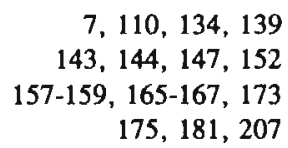

$175,181,207$

Aandeel op naam levering 27-30, 32-35, 178

Aandeelhouder zonder stemrecht $\quad 55$

Aandeelhouders
-belang
11,70
-rechten
$7,53,54,68$

$72-74,82,84,85,186$

-registe 3, 34, 36, 41-43,104, 105, 212

algemene vergadering van - $13,14,21$

$24,49-51,53$

$54,62,70,71$

persoonlijke aansprakelijkheid van - 23 vennootschappelijke betrokken-

heid van -

Administratiekantoor

$71,76,80-83$

$85,88,91,140,161$ $167-170,172,173$

executie onder 174

faillissement van -

Administratievoorwaarden

$72,76,81,82$

$85,90,171,172$

Afstand

- van het recht op reflectie

110

- van het recht tot uitkoop

194

197,200

- van pandrecht

113

Akte

authentieke -

$16,27,36$

betekening

$33-35,43$

geregistreerde onderhandse -

16,27

$29,30,36$

$41,44,176$

notarièle -

$31,32,41,44,181$

B

Beleggend publiek

$120,123,127$

$128,133,153$

bescherming van -

121,124

$127,133,138$

Beschikkingsbevoegdheid 15

Beslag op aandelen conservatoir beslag:

- aandelen aan toonder 107

- aandelen op naam 107

- algemeen 106

executoriaal beslag:

- aandelen aan toonder $\quad 106$

- aandelen op naam 104

- algemeen 102

Besloten vennootschap $\quad 128,133$

$134,136-138,148,160$

intern- $\quad 139,143,147,151$

$154,155-159,179,180$

niet intern- 140,148

open - $\quad 134,148$

Beslotenheid $\quad 7,9,11,39,49,50$

$52,74,80,81,95,117$

$125,126,133,143,179$

- en blokkeringsregeling 143

- en certificering van aandelen 166

$168,169,174$

- en de algemene vergadering

van aandeelhouders $133,137,139$

$144,155,156,159$

- en de vrije kring $139,140,143,179$

- en erfrechtelijke blokkade 139

$140,146,147$

- en juridische fusie 186

- en overgang van stemrecht 151

- en preferente beschermingsaandelen

163,165

- en prioriteitsaandelen 162

- en reflectie 158, 159

- en stemovereenkomst 148

- en stil pandrecht 176, 177

- en verpanding van aandelen 139,140

$145,151-153$

$156,157,159,160$

- en vertegenwoordiging krachtens

volmacht 148

- en volmacht $139,140,148$

- en wettelijk pandrecht 166

doorbraak van - $\quad 146,148,151$

$152,154,156$

$158,160,166,176$ 
externe -

grondslag van -

127,137

$126,136,138$

148,160

interne -

$127,137,145$

wettelijke bescherming bij

verpanding van aandelen

Besnurspand

Betekening

- van de akte van levering

- van de akte van vestiging pandrecht

$31,36,38$ $40-43,176,177,180$

- van overdracht 30

- van procesverbaal van inbeslagneming

Bewilliging; zie certificering van aandelen; medewerking

Bewind

Bewindvoerder

$78,93,166,172-175$

Bijzondere titel

146

Blokkeringsregeling

$9,10,40,51,52$

$64,76,90,93,94$

$133,134,138,140,141$

$143,145,148,160$

$166,174,175,186$

\section{C}

Certificaathouders -rechten

$55,59,67,68,72$

$73,84,88,151$

Certificering van aandelen $69,71,166,174$ deelcertificering

171,176

doel

72,168

medewerking

$66,69,72$

medewerking; definitie

$74,75,77$

omschrijving

71

overdracht van certificaten

89

royering van verpande certificaten 91

Cessie

$27,28,50$

Claimrecht

60

Commanditaire vennootschap op

aandelen

Commissie Vennootschapsrecht

Commissie Verdam

128

Conversie

Curator

$170,171,175$

102,111

D

Derde anti-misbruikwet

29,30

Derdenpand

191

Deurwaarder

$102-105,181$
Dividend

$60,69,70,82$

$101,104,147,164$

preferent -

166

E

Eerste EG-richtlijn 131,132

Erkenning

- van levering

34-35

- van overdracht

31

- van vestiging pandrecht $31,36,37$

$40-43,176,177,180$

Executie van aandelen

95

- aan toonder

98

- en faillissement

111

- op naam

98

executie; algemeen

97

parate executie

F

Fusiegedragsregels

G

Geschillenregeling 189, 205

- gedwongen stemrecht overgang 207

- pandhouder en gedwongen

stemrecht overgang $\quad 212,213$

- pandhouder en uitstoting 208-211

- pandhouder en uittreding $\quad 211,212$

- toepassingsgebied 205

- uittreding 207

Goederenrechtelijke werking 45

Goedkeurend orgaan $\quad 8,138-140$

144,154

Goedkeuring $\quad 17-19,49,51$

$62,70,73,76$

$110,133,143,151$

$156-158,178,181,186$

- achteraf

180

weigering van -

$8,110,144$

$154,157,165,180$

Goedkeuringsblokkade $\quad 8,76,110,134$

$139,140,143,144$

$151,159,165,181$

H

Herverpanding

overgang stemrecht bij -

62

I

Inpandneming eigen aandelen 21,22

- en stemrecht 25

- kapitaal realiteit 
J

Juridische fusie

- en het stemrecht van de pandhouder

bescherming van de pandhouder

bij -

184,185

omschrijving

ruilverhouding bij -

183,184

$\mathbf{K}$

Koninklijke bewilliging

Kwaliteitseisen

39,134

$\mathbf{L}$

Legaat

8,16

Levering

15

Lidmaatschapsrechten

$66,67,75,79,83$

$84,89,90,166$

Lidmaatschapsverhouding

- aandeelhouder - vennootschap 53,65

- certificaathouder -

vennootschap

$84-86,89$

- certificaathouder/

pandhouder - vennootschap 84, 86-87

- pandhouder - vennootschap65, 66, 148

$\mathbf{M}$

Meerderheidsaandeelhouder

120,144

159,199

Minderheidsaandeelhouder

120,159

$192,195,196$

$198,199,201$

$\mathbf{N}$

Naamloze vennootschap

$133,134,138$

besloten -

$120,124,125$

$127-129,131,132$

$135,160,210$

gemengde - $\quad 141,160,161$

$172,175,180$

140

intern-besloten -

120,124

open (openbare) -

$125,127,129$

$131,135,140$

$153,166,176-178$

o

Omwisseling

91,167

120

Ontwerp Donner

$120,125,126$
Openbaar bod

185

Organisatorische betrokkenheid; zie ook lidmaatschaps-

verhouding

$66-68,84,88,148$

Overdracht

- van aandelen

$9,28,30,36$

$49,91,109,126$

133. $134,145,146$

$157,159,173$

$174,181,191$

gedwongen - van aandelen $\quad 205,211$

Overgang van aandelen

147

P

Pandgever

- en bezitloos pand 16, 27

- en de aanbiedingsregeling

- en de geschillenregeling 210, 211-213

- en de juridische fusie 187

- en de uitkoopregeling 196

198, 200-203

- en vuistpand 113

beschikkingsbevoegdheid van de - 15

beschikkingsonbevoegdheid van de - 45

faillissement van de -

mededeling van gevestigd pandrecht 44

persoonlijk belang van de - $\quad 10$

recht op inlichtingen 59

relatie pandhouder - $\quad 67,108,110$

rol van de - in de AVA 151

stemrecht van de - $\quad 145,155,177$

stemrechtuitoefening door de - 47,48

tekortschieten van de - $\quad 36,40,159$

tweede -

63

verlies stemrecht $\quad 10,146,153,179$

verplichting tot vergoeding

van kosten door - $\quad 58$

vordering tot afgifte van het

pand door de -

58

Pandhouder

bevoegdheid tot herverpanding $\quad 61-63$

- en verandering van de aard

van het pandrecht

60

recht op vergoeding van kosten 58,59

recht van terughouding van

het aandeel

zonder stemrecht in besloten

vennootschap

55,67

zonder stemrecht in naamloze

vennootschap

55,67 
zonder stemrecht;

algemeen

$67,145,151$

zorgplicht ten aanzien van het

verpande aandeel $\quad 58$

Pandrecht 16

- op aandelen in een girodepot 46

- op aandelen in een verzameldepot 46

- op beschermingsaandelen 163

164,166

- op een bewilligd certificaat 89

accessoir karakter $\quad 49,113$

bescherming tegen onbevoegdheid pandgever 45

bezitloos pand $\quad 15$

einde van het - $\quad 113$

executie 22

goede trouw $\quad 41-43$

mogelijkheid vestiging

- algemeen 15

- besloten vennootschap 18

- naamloze vennootschap 16-18

openbaar pand $\quad 16,36,178,179$

stil pand $\quad 16,35-41,43$

$176,178,179,181$

vertord van vestiging - $\quad 8$

voorwaarden voor geldige vestiging 15

vuistpand

wijze van vestiging;

aandeel aan toonder aandeel op naam

Preferente aandelen

Prioriteitsaandelen

Publikatieverplichting

$27,28,31-36$

$134,152.161$

163-165, 180

134,141

$152,161,162$

$180,194,197$

120-124, 128

$132,135-138$

$\mathbf{R}$

Redelijkheid en billijkheid

59,68

85,87

$170,174,199$

Reflecteren door het

administratiekantoor

$167,168,170$

$171,173,174$

Reflecteren door mede-

aandeelhouders

$110,144,158$

159. 181

Royering

$91,168,171,172,175$

S

Stemovereenkomst

146,148

\section{Stemrecht}

- preferente beschermingsaandelen 50

- van de aandeelhouder $\quad 10,53,145$

- van de houder van stil pandrecht

$56,177,178$

- van de pandhouder

$10,11,47$

$54,65-67$

$86,147,151$

- van de vruchtgebruiker

$9,10,154$

en conservatoir beslag

107

en economische waarde aandeel 11

47,154

hoofdregel naamloze vennootschap 48

latere overgang van - $\quad 153,178$

overgang

- bij besloten vennootschap 18

$19,51,52$

- bij naandoze vennootschap 18

$19,50,51$

- naar pandhouder $13,14,48,145$

- verbonden aan verpande aandelen

- bij herverpanding

rol algemene vergadering

bij overgang $\quad 49,50,179,180$

uitoefening krachtens volmacht

uitsluiting overgang - bij

besloten vennootschap

verbonden aan gecertificeerde

aandelen

vereisten voor overgang

bij besloten vennootschap 51

bij naamloze vennootschap 50

Stockdividend

\section{$\mathbf{T}$}

Titel

Tweede EG-richtijn

U

Uitkoopregeling

$189,191,193$

- en eigendomsrecht

- en prioriteitsaandelen

194

afwijzing van de vordering 194,199

benoeming van deskundigen $\quad 195$

consignatie 195, 197, 202

onbezwaand recht op aandelen 195, 197

verbod selectieve uitkoop

193

Uitkoopregeling en pandrecht relatie pandgever-pandhouder

201-203 
relatie uitkoper-aandeelhouder/

pandgever

196-199

relatie uitkoper-pandhouder

200,201

V

Verkrijging onder algemene titel 146,183

Vierde EG-richtlijn $\quad 136$

Volstorting

Voorkeursrecht

Vruchtgebruik

- op aandelen

$54,59,69$

$8-10,16$

$50,54,104$

$154,185,195$

W

Wettelijk pandrecht $\quad 166$

- ten behoeve van certificaathouders 69

executie van -

$92,93,167$

$172,173,175$

faillissement van het AK

94

geen dwingend recht

81,83

medewerking

79-81

ontstaan van -

74,77

ontstaan van lidmaatschapsverhouding

85-87

uitsluiting van

- in administratievoorwaarden $\quad 92$

- in statuten 81

vs 'gewoon' pandrecht 83

$\mathbf{Z}$

Zaaksvervanging $\quad 91,184,185$ 


\section{Curriculum Vitae}

Jos Hamers werd geboren op 14 december 1966 te Nuth. In 1985 haalde hij het VWO-diploma aan de Scholengemeenschap Sinter Meerten te Heerlen. Hij studeerde Nederlands recht aan de Rijksuniversiteit Limburg te Maastricht. Het doctoraalexamen behaalde hij in september 1989. Sedertdien is hij verbonden aan de Faculteit der Rechtsgeleerdheid, vakgroep privaatrecht, van de Rijksuniversiteit Limburg, in de periode 1989-1993 als assistent in opleiding en vanaf september 1993 als universitair docent Handels- en Ondernemingsrecht. 

